PNNL-18876

WTP-RPT-205, Rev 0

U.S. DEPARTMENT OF ENERGY

Prepared for the U.S. Department of Energy under Contract DE-AC05-76RL01830

\title{
Laboratory Tests on Post-Filtration Precipitation in the WTP Pretreatment Process
}

RL Russell

RA Peterson
DE Rinehart

JV Crum

November 2009

Pacific Northwest NATIONAL LABORATORY

Proudly Operated by Battelle Since 1965 


\title{
Laboratory Tests on Post-Filtration Precipitation in the WTP Pretreatment Process
}

\author{
RL Russell \\ DE Rinehart \\ RA Peterson \\ JV Crum
}

November 2009

Test Specification: 24590-PTF-TSP-RT-07-001, Rev 2

Test Plan: TP-WTP-PEP-044, Rev 0.2

Test Exceptions: 24590-WTP-TEF-RT-09-0001, Rev 1

24590-WTP-TEF-RT-09-0002, Rev 0

R\&T focus area: Pretreatment

Test Scoping Statement: 24590-WTP-PL-RT-07-0002 Rev 0. SS: M6-3

Pacific Northwest National Laboratory

Richland, Washington 99352 
WTP-RPT-205, Rev 0

\section{Completeness of Testing}

This report describes the results of work and testing specified by Test Exceptions 24590WTP-TEF-RT-09-0001 Rev 1 and 24590-WTP-TEF-RT-09-0002 Rev 0 under Test Specification, 24590-PTF-TSP-RT-07-001, Rev 2 and Test Plan TP-WTP-PEP-044, Rev 0.2 . The work followed the quality assurance requirements outlined in the Test Specification and Test Plan. The descriptions provided in this report are an accurate account of both the conduct of the work and the data collected. Test Plan results are reported. Also reported are any unusual or anomalous occurrences that are different from expected results. The test results and this report have been reviewed and verified.

Approved:

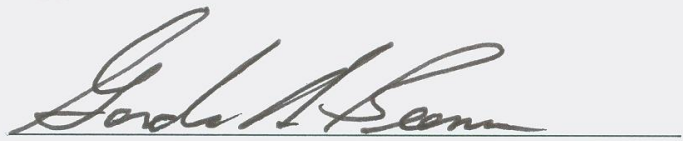

Gordon H. Beeman, Manager WTP R\&T Support Project

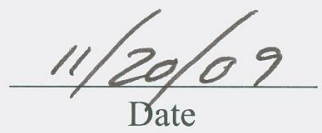

Date 


\section{Contents}

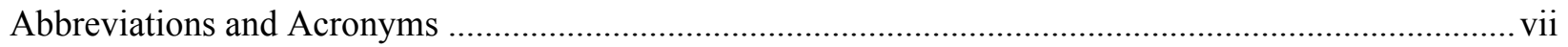

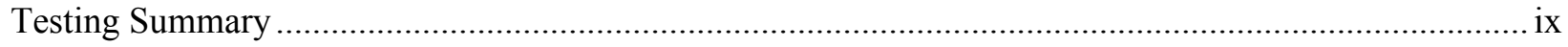

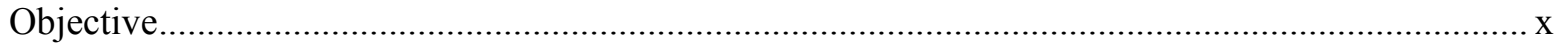

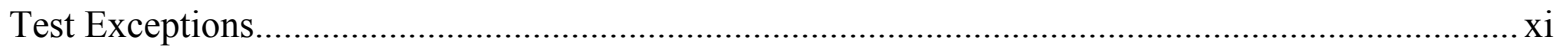

Results and Performance Against Success Criteria ...................................................................... xii

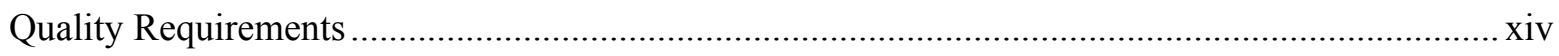

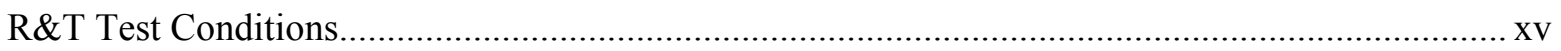

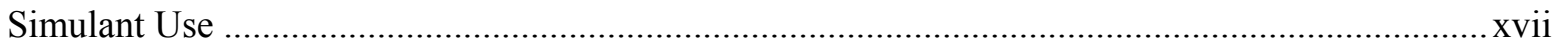

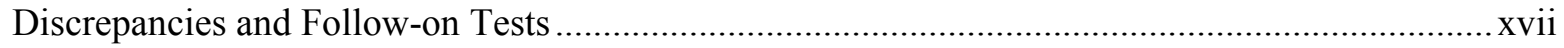

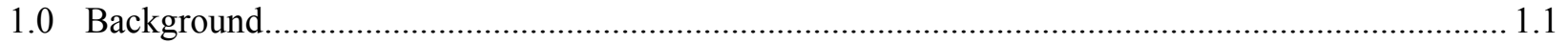

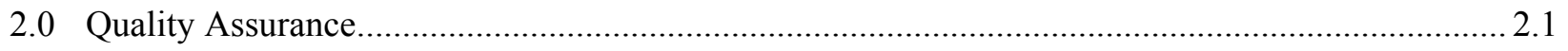

3.0 Post-Filtration Precipitate and Solution Characterizations .......................................................... 3.1

4.0 Determination of Rate of Approach to Equilibrium Concentrations ............................................. 4.1

5.0 Identification and Characterization of Precipitates....................................................................... 5.1

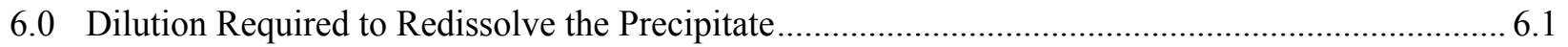

7.0 Supersaturation in Post-Caustic-Leach Filtrates from PEP Integrated Test B ............................. 7.1

8.0 Effects of Blending During the Post-Caustic-Leach Dewatering and Wash Cycle......................... 8.1

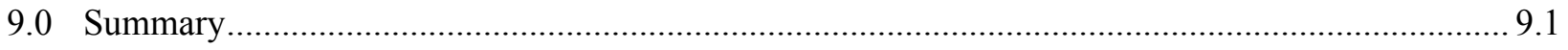

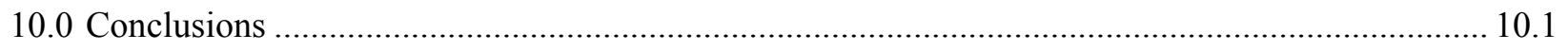

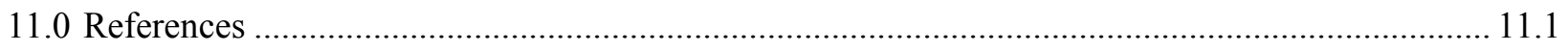

Appendix A: Chemical Analysis Results ...................................................................................... A.1 


\section{Figures}

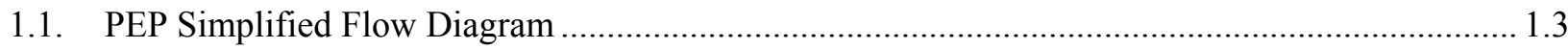

3.1. Phosphate and Oxalate Concentration Plot with PEP Integrated Test A Wash Step...................... 3.3

3.2. Filtered Solids and Filter Paper from the PEP Integrated Test A Samples Analyzed ..................... 3.4

3.3. Polarized Light Optical Microscopy (OM) of Sodium Phosphate in Sample 2341 (Wash 3)........ 3.5

3.4. Cross-Polarized Light OM of Sodium Phosphate in Sample 2341 (Wash 3)............................... 3.5

3.5. Cross-Polarized Light OM of Sodium Phosphate in Sample 2341 (Wash 3) with Full Wave

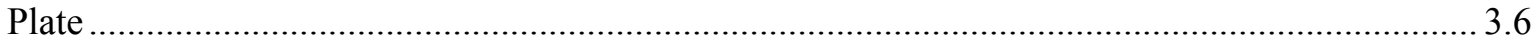

3.6. Polarized Light OM of Sodium Phosphate in Sample 2349 (Wash 11) ....................................... 3.6

3.7. Cross-Polarized Light OM of Sodium Phosphate in Sample 2349 (Wash 11).............................. 3.7

3.8. Cross-Polarized Light OM of Sodium Phosphate in Sample 2349 (Wash 11) with Full Wave

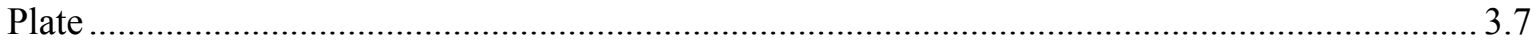

3.9. Polarized Light OM of Sodium Phosphate in Sample 2363 (Wash 25) ....................................... 3.8

3.10. Cross-Polarized Light OM of Sodium Phosphate in Sample 2363 (Wash 25)............................. 3.8

3.11. Cross-Polarized Light OM of Sodium Phosphate in Sample 2363 (Wash 25) with Full Wave

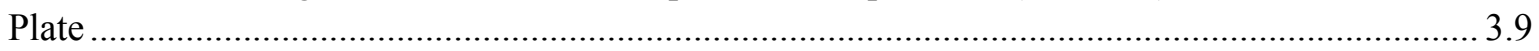

3.12. Cross-Polarized Light OM of Sodium Oxalate in Sample 2369 (Wash 31)................................. 3.9

3.13. XRD Pattern of Crystals from Integrated Test A Wash 3 (Sample Bottle 2341) Identified to be Sodium Hydrogen Phosphate $\left(\mathrm{Na}_{2} \mathrm{HPO}_{4}\right)$

3.14. XRD Pattern of Crystals from Integrated Test A Wash 11 (Sample Bottle 2349) Identified to be Sodium Hydrogen Phosphate $\left(\mathrm{Na}_{2} \mathrm{HPO}_{4}-2 \mathrm{H}_{2} \mathrm{O}\right)$

3.15. XRD Pattern of Crystals from Integrated Test A Wash 25 (Sample Bottle 2363) Identified to be Sodium Hydrogen Phosphate $\left(\mathrm{Na}_{2} \mathrm{HPO}_{4}-2 \mathrm{H}_{2} \mathrm{O}\right)$

3.16. XRD Pattern of Crystals from Integrated Test A Wash 31 (Sample Bottle 2369) Identified to be Sodium Oxalate $\left(\mathrm{Na}_{2} \mathrm{C}_{2} \mathrm{O}_{4}\right)$.

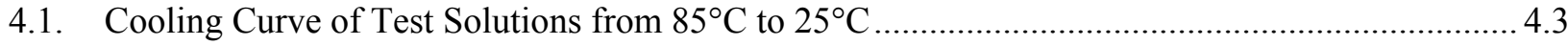

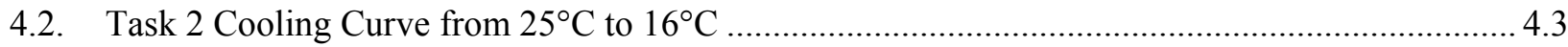

4.3. Precipitate in $85^{\circ} \mathrm{C}$ Samples from Tests T2-7, T2-8, and T2-9 (from right to left) after 24

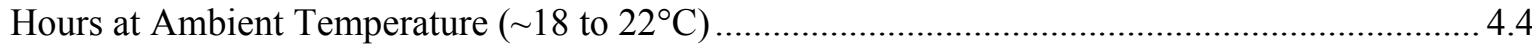

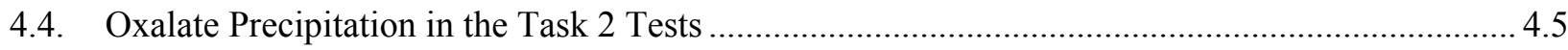

4.5. Phosphate Precipitation in the Task 2 Tests ............................................................................... 4.6

4.6. Effect of Fluoride Concentration on the Phosphate Concentration 144 Hours After Cooling

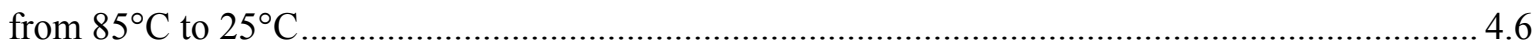

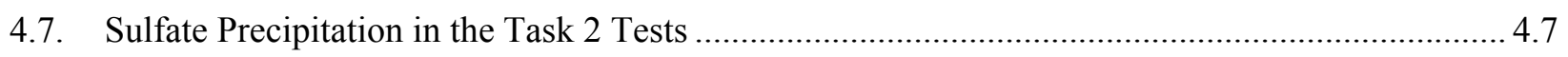

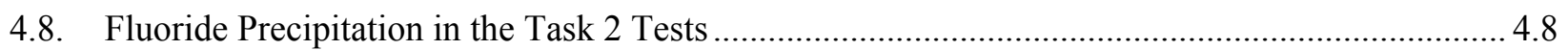

5.1. Solids Produced in Test T3-4 (Spiked with Sodium Phosphate) .................................................... 5.3

5.2. $\quad$ Test T3-4 (Spiked with Sodium Phosphate) Solids Settling ….................................................... 5.4 
5.3. Initial Settling Rate of Test T3-4 (Spiked with Sodium Phosphate) ........................................... 5.4

5.4. Overall Settling Rate of Test T3-4 (Spiked with Sodium Phosphate) .......................................... 5.5

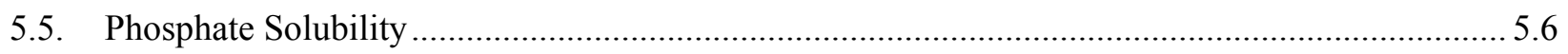

5.6. Impact of Temperature on Solubility Measured at 24 Hours ..................................................... 5.7

5.7. Sample T3-1a $\left(\mathrm{Na}_{7} \mathrm{~F}\left(\mathrm{PO}_{4}\right)_{2} \cdot 19 \mathrm{H}_{2} \mathrm{O}\right) \mathrm{OM}$ in Polarized Light ........................................................ 5.8

5.8. Sample T3-1b $\left(\mathrm{Na}_{7} \mathrm{~F}\left(\mathrm{PO}_{4}\right)_{2} \cdot 19 \mathrm{H}_{2} \mathrm{O}\right) \mathrm{OM}$ in Polarized Light ....................................................... 5.8

5.9. Sample T3-1c $\left(\mathrm{Na}_{7} \mathrm{~F}\left(\mathrm{PO}_{4}\right)_{2} \cdot 19 \mathrm{H}_{2} \mathrm{O}\right) \mathrm{OM}$ in Polarized Light ....................................................... 5.9

5.10. Sample T3-3 $\left(\mathrm{Na}_{7} \mathrm{~F}\left(\mathrm{PO}_{4}\right)_{2} \cdot 19 \mathrm{H}_{2} \mathrm{O}\right) \mathrm{OM}$ in Polarized Light ..................................................... 5.9

5.11. Sample T3-5 $\left(\mathrm{Na}_{7} \mathrm{~F}\left(\mathrm{PO}_{4}\right)_{2} \cdot 19 \mathrm{H}_{2} \mathrm{O}\right) \mathrm{OM}$ in Polarized Light ..................................................... 5.10

5.12. Sample T3-4 in $\left(\mathrm{Na}_{3} \mathrm{PO}_{4} \cdot 12 \mathrm{H}_{2} \mathrm{O}\right) \mathrm{OM}$ Cross-Polarized Light................................................ 5.10

5.13. Sample T3-4 $\mathrm{Na}_{3} \mathrm{PO}_{4} \cdot 12 \mathrm{H}_{2} \mathrm{O}$ Crystals in OM Cross-Polarized Light with Full Wave Plate......... 5.11

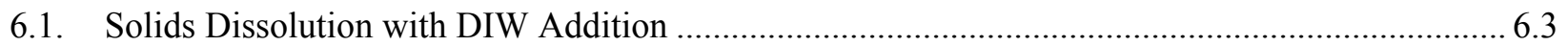

7.1. Oxalate Concentration Relative to Na During PEP Integrated Test B Washes............................ 7.2

7.2. Phosphorus Concentration Relative to Na During PEP Integrated Test B Washes....................... 7.3

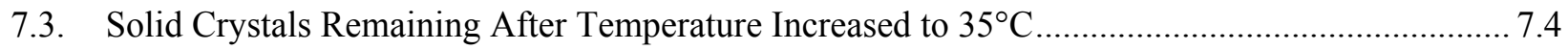

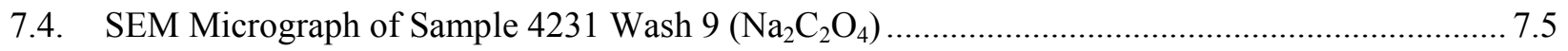

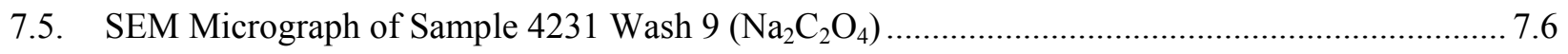

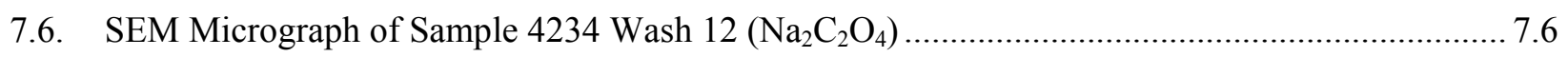

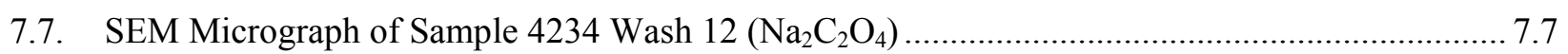

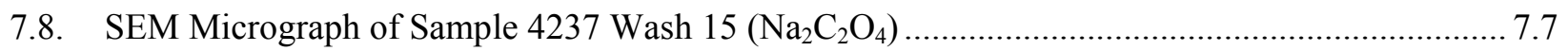

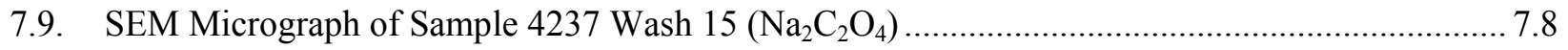

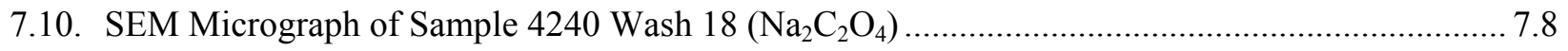

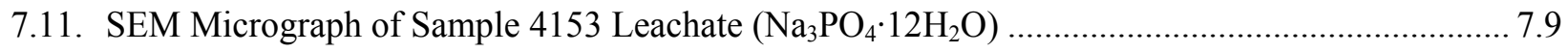

8.1. Blend 2 Solids Formed after Sitting at Ambient Laboratory Temperature ................................. 8.2

8.2. Blend 5 Solids Formed after Sitting at Ambient Laboratory Temperature .................................. 8.3 


\section{Tables}

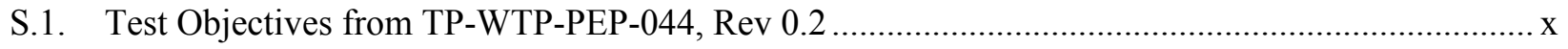

S.2. Test Exceptions for Test Plan TP-WTP-PEP-044, Rev 0.2 .......................................................

S.3. Results and Performance against Success Criteria of TP-WTP-PEP-044, Rev 0.2 ...................... xii

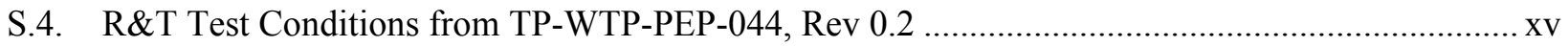

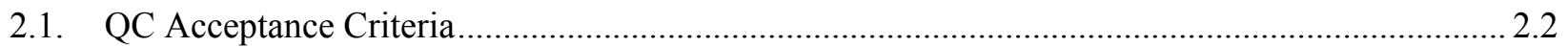

3.1. ICP Results for Integrated Test A Post-Caustic Wash Solutions Composition.............................. 3.2

3.2. IC Results for Integrated Test A Post-Caustic Wash Solutions Composition ................................ 3.2

3.3. Density Results for Integrated Test A Post-Caustic Wash Solutions Composition ....................... 3.2

3.4. Weights of Filtered Solids in Integrated Test A Samples............................................................... 3.4

3.5. Summary of Measured Crystal Dimensions for Each Sample .................................................. 3.10

3.6. ICP Results for Integrated Test A Post-Caustic-Precipitate Composition Dissolved in DIW ...... 3.13

3.7. IC Results for Integrated Test A Post-Caustic-Precipitate Composition Dissolved in DIW......... 3.13

4.1. Simplified Post-Caustic-Leach Slurry Simulant Composition ..................................................... 4.1

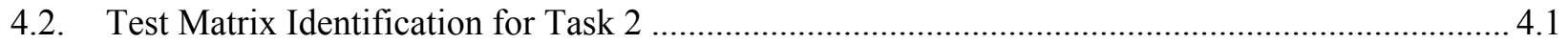

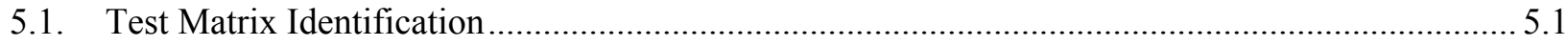

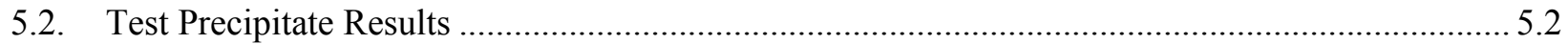

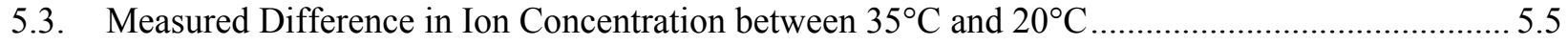

5.4. Summary of Measured Crystal Dimensions for Each Sample .................................................... 5.12

6.1. Amount DIW Required to Achieve Complete Dissolution of Solids ........................................... 6.2

7.1. Solids Left in Samples after Test Completed ........................................................................... 7.3

7.2. Measured Compositions of Task 5 Dried Crystals …................................................................ 7.5

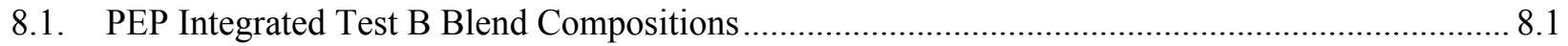

8.2. Solids Formed in Blends after Test Completed ......................................................................... 8.2 


\section{Abbreviations and Acronyms}

$\begin{array}{ll}\text { AFA } & \text { anti-foam agent } \\ \text { APEL } & \text { Applied Process Engineering Laboratory } \\ \text { ASME } & \text { American Society of Mechanical Engineers } \\ \text { BNI } & \text { Bechtel National Incorporated } \\ \text { BS } & \text { blank spike } \\ \text { CFR } & \text { Code of Federal Regulations } \\ \text { DIW } & \text { deionized water } \\ \text { DOE } & \text { U.S. Department of Energy } \\ \text { EFRT } & \text { External Flowsheet Review Team } \\ \text { HDI } & \text { How Do I....? } \\ \text { IC } & \text { ion chromatography } \\ \text { ICP } & \text { inductively coupled plasma } \\ \text { IW } & \text { inhibited water } \\ \text { LCS } & \text { laboratory control sample } \\ \text { OM } & \text { optical microscopy } \\ \text { PDLW } & \text { Process Development Laboratory West } \\ \text { PEP } & \text { Pretreatment Engineering Platform } \\ \text { PLM } & \text { polarized light microscopy } \\ \text { PNNL } & \text { Pacific Northwest National Laboratory } \\ \text { PSD } & \text { particle-size distribution } \\ \text { PTF } & \text { Pretreatment Facility } \\ \text { QAM } & \text { Quality Assurance Manual } \\ \text { QAP } & \text { quality assurance program } \\ \text { QARD } & \text { Quality Assurance Requirements and Descriptions (document) } \\ \text { QC } & \text { quality control } \\ \text { RPP } & \text { River Protection Project } \\ \text { R\&T } & \text { research and technology } \\ \text { SEM } & \text { scanning electron microscopy } \\ \text { UDS } & \text { undissolved solids } \\ \text { UFP } & \text { ultrafiltration process } \\ \text { WTP } & \text { Hanford Tank Waste Treatment and Immobilization Plant } \\ \text { XRD } & \text { X-ray diffraction } \\ & \end{array}$





\section{Testing Summary}

This report includes the results of the precipitation study testing performed in accordance with Test Exception 24590-WTP-TEF-RT-09-0001, Rev 1, for Test Plan TP-WTP-PEP-044, Rev 0.2, ${ }^{(a)}$ which was prepared and approved in response to Test Specification 24590-WTP-TSP-RT-07-001, Rev 2 (Huckaby 2008).

Significant post-filtration precipitation was observed in the post-caustic leachate and wash solutions while the leaching and ultrafiltration processes were demonstrated in the Pretreatment Engineering Platform (PEP). Precipitation in these streams could lead to precipitates accumulating in filtrate receipt vessels and in the feed to ion exchange columns. Post-filtration precipitation in the feed to the ion-exchange column, if it occurs, will severely impact the operability of the unit and the pretreatment process. Therefore, a laboratory study was carried out to develop an understanding of the phenomenon of post-filtration precipitation and the help in identifying the pathways to mitigate it. This report summarizes the results from the laboratory studies to support this objective. The salient findings from the study are as follows:

- The polarized light microscopy (PLM) mineralogical characterizations and the chemical compositions found the precipitates observed in the PEP to be predominantly sodium phosphate and sodium oxalate.

- The presence of phosphate, sulfate, and fluoride anions do not appear to have an effect on this final equilibrium composition of oxalate, but do appear to slow down the rate of precipitation of oxalate.

- Phosphate precipitates rapidly with the solution reaching close to equilibrium in about 12 hours in the absence of fluoride. However, the presence of fluoride anions appears to slow down the approach of phosphate to equilibrium and has a strong effect on the final equilibrium phosphate concentration. There appears to be no significant effects on the rate of phosphate precipitation from the presence of oxalate, sulfate, and silicate anions in solution.

- The precipitation of sulfate appears to be affected very significantly by the presence of fluoride anions. However, the presence of fluoride appeared to have no effect on the rate of approach of sulfate to its apparent equilibrium concentration.

- The fluoride appears to reach equilibrium composition very rapidly within 12 hours. The presence of both phosphate and oxalate anions appears to suppress the equilibrium concentration of fluoride very significantly at $25^{\circ} \mathrm{C}$, while sulfate may not have an effect. The presence of other anions does not appear to affect the rate of approach of fluoride to equilibrium concentration.

- In all cases, precipitates when observed settled very rapidly in less than 1 hour.

- In the presence of fluoride and phosphate anions, the precipitate observed was $\mathrm{Na}_{7} \mathrm{~F}\left(\mathrm{PO}_{4}\right)_{2} \cdot 19 \mathrm{H}_{2} 0$. In the absence of fluorides, the phosphate anion appeared to form $\mathrm{Na}_{3}\left(\mathrm{PO}_{4}\right) \cdot 12 \mathrm{H}_{2} \mathrm{O}$.

- The particle-size analysis performed using the I-mage software on the polarized light micrographs indicates that the $\mathrm{Na}_{7} \mathrm{~F}\left(\mathrm{PO}_{4}\right)_{2} \cdot 19 \mathrm{H}_{2} \mathrm{O}$ particles ranged from a minimum of $20 \mu \mathrm{m} \times 20 \mu \mathrm{m}$ (length $\times$ width) to a maximum of $2600 \mu \mathrm{m} \times 1400 \mu \mathrm{m}$ with the mean size in the range of $225 \mu \mathrm{m}$ to $715 \mu \mathrm{m}$ in length and $30 \mu \mathrm{m}$ to $175 \mu \mathrm{m}$ in width. Primary crystals of $\mathrm{Na}_{7} \mathrm{~F}\left(\mathrm{PO}_{4}\right)_{2} \cdot 19 \mathrm{H}_{2} \mathrm{O}$ appeared to be hexahedrons in shape.

(a) RL Russell. 2008. "Test Plan for the PEP Parallel Laboratory Testing." TP-WTP-PEP-044, Rev 0.2. Pacific Northwest National Laboratory, Richland, Washington. 
- The $\mathrm{Na}_{3}\left(\mathrm{PO}_{4}\right) \cdot 12 \mathrm{H}_{2} \mathrm{O}$ particles were significantly smaller in size, ranging from a minimum of $108 \mu \mathrm{m} \times 16 \mu \mathrm{m}$ to a maximum of $2500 \mu \mathrm{m} \times 76 \mu \mathrm{m}$, with a mean of $610 \mu \mathrm{m} \times 35 \mu \mathrm{m}$. The primary crystals of $\mathrm{Na}_{3}\left(\mathrm{PO}_{4}\right) \cdot 12 \mathrm{H}_{2} \mathrm{O}$ were needle like in shape.

- The precipitates redissolve upon dilution with water. The degree of dilution varied, but in general complete dissolution of the precipitates could be achieved through dilution.

- The phosphate precipitates could be redissolved at temperatures $\leq 35^{\circ} \mathrm{C}$, when heated.

- Precipitates of oxalate could form when leachate and wash solutions are blended together because of a common ion effect from the increased sodium ion concentration in the blend relative to the wash solutions.

\section{Objective}

The test objectives for the work addressed in TP-WTP-PEP-044, Rev $0.2^{(\mathrm{a})}$ are summarized in Table S.1 along with a discussion of how the objectives were met. Only the fifth test objective is addressed in this report as the others were all addressed in previous reports.

Table S.1. Test Objectives from TP-WTP-PEP-044, Rev 0.2

\begin{tabular}{|c|c|c|}
\hline Test Objective & Objective & Discussion \\
\hline $\begin{array}{l}\text { 1) Establish scale factors between } \\
\text { laboratory process } \\
\text { measurements (e.g., leach } \\
\text { factors, filter fluxes) and those } \\
\text { of the Pretreatment Engineering } \\
\text { Platform (PEP). }\end{array}$ & NA & $\begin{array}{l}\text { This objective was addressed in reports } \\
\text { WTP-RPT-186, Rev } 0 \text {, WTP-RPT-188, Rev 0, and } \\
\text { WTP-RPT-197, Rev } 0 \text {. }\end{array}$ \\
\hline $\begin{array}{l}\text { 2) Maximize the comparability of } \\
\text { the laboratory and PEP process } \\
\text { measurements and simplify the } \\
\text { development of the scaling } \\
\text { relationships. Slurry samples } \\
\text { will be collected from the PEP at } \\
\text { appropriate points during the } \\
\text { testing, transported to a } \\
\text { laboratory, and subjected to } \\
\text { analogous laboratory testing. } \\
\text { Filter flux measurements for } \\
\text { slurries with low and high solids } \\
\text { concentrations, caustic leaching, } \\
\text { and oxidative leaching will each } \\
\text { be examined in this fashion. }\end{array}$ & NA & $\begin{array}{l}\text { This objective was addressed in reports } \\
\text { WTP-RPT-186, Rev 0, WTP-RPT-188, Rev 0, and } \\
\text { WTP-RPT-197, Rev } 0 .\end{array}$ \\
\hline $\begin{array}{l}\text { 3) Permeate precipitation testing } \\
\text { will be performed to evaluate the } \\
\text { propensity of the Phase I } \\
\text { simulant permeates to precipitate } \\
\text { solids. }\end{array}$ & NA & $\begin{array}{l}\text { This objective was addressed in report WTP-RPT-200, } \\
\text { Rev } 0 .\end{array}$ \\
\hline
\end{tabular}


Table S.1. Test Objectives from TP-WTP-PEP-044, Rev 0.2

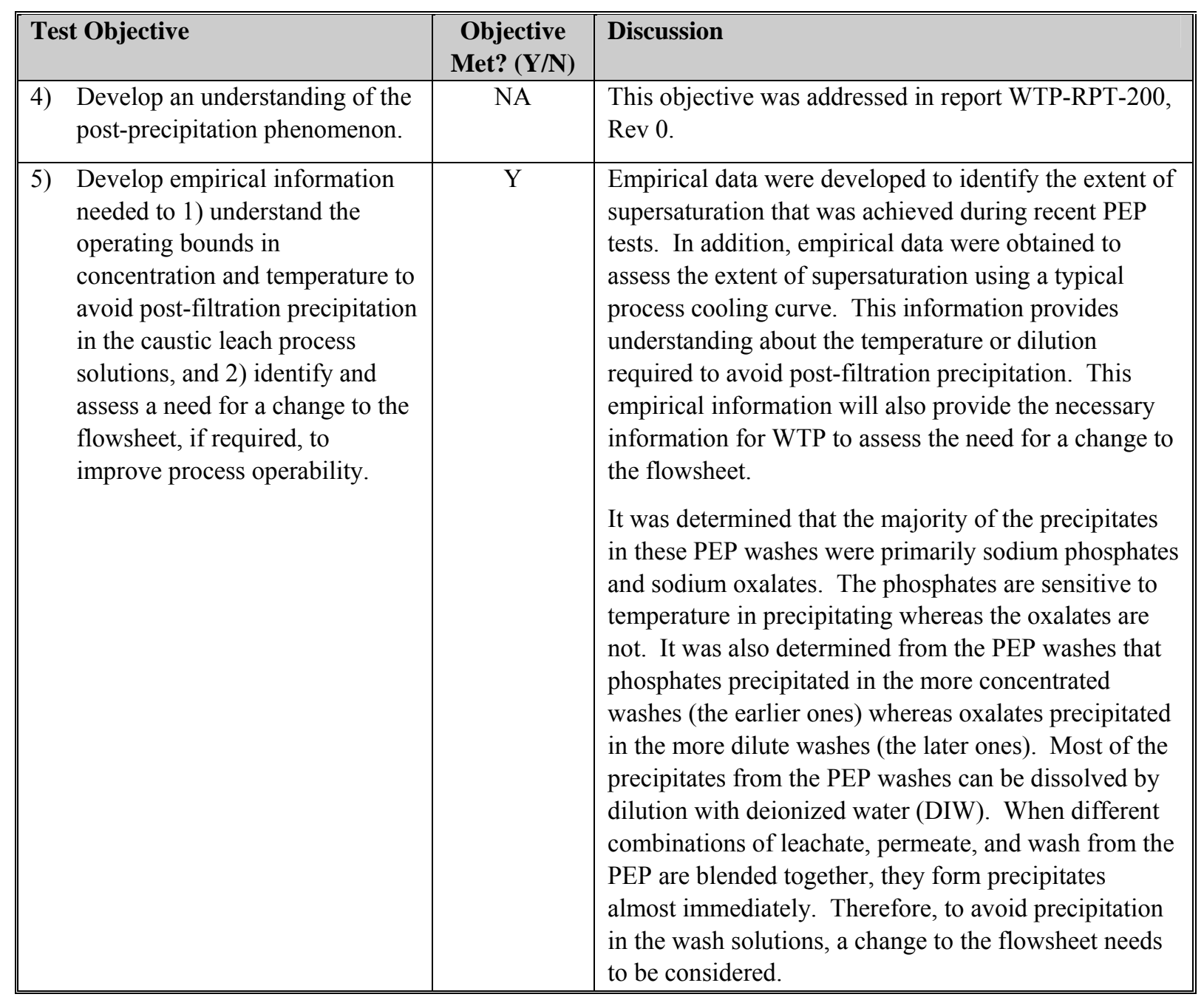

\section{Test Exceptions}

There were two Test Exceptions issued for Test Plan TP-WTP-PEP-044, Rev 0.2. These test exceptions are summarized in Table S.2 along with a brief description of how each test exception impacted existing objectives and the test plan scope. 
Table S.2. Test Exceptions for Test Plan TP-WTP-PEP-044, Rev 0.2

\begin{tabular}{|l|l||}
\hline \hline List Test Exceptions & Describe Test Exceptions \\
\hline 24590-WTP-TEF-RT-09-0001, Rev 1 & $\begin{array}{l}\text { This Test Exception did not affect any existing test plan objectives. It } \\
\text { added test objectives concerned with 1) understanding the operating } \\
\text { bounds in concentration and temperature to avoid post-filtration } \\
\text { precipitation in the caustic leach process solutions, and 2) identifying } \\
\text { and assessing a need for a change to the flowsheet, if required, to } \\
\text { improve process operability. This is objective 5 in Table S.1. }\end{array}$ \\
\hline 24590-WTP-TEF-RT-09-0002, Rev 0 & $\begin{array}{l}\text { This Test Exception did not affect any existing test plan objectives. It } \\
\text { added test objectives concerned with developing an understanding of the } \\
\text { post-filtration precipitation process. This is objective } 4 \text { in Table S.1. }\end{array}$ \\
\hline \hline
\end{tabular}

\section{Results and Performance Against Success Criteria}

The success criterion described in TP-WTP-PEP-044, Rev 0.2 that this testing met is presented in Table S.3.

Table S.3. Results and Performance Against Success Criteria of TP-WTP-PEP-044, Rev 0.2

\begin{tabular}{||l|l||}
\hline List Success Criteria & $\begin{array}{l}\text { Explain How the Tests Did or Did Not } \\
\text { Meet the Success Criteria }\end{array}$ \\
\hline $\begin{array}{l}\text { 1. Generate testing results that allow a scale-up factor } \\
\text { from the laboratory testing to the PEP testing to be } \\
\text { generated. }\end{array}$ & $\begin{array}{l}\text { 1. This criterion is not addressed in this report. This } \\
\text { was addressed in reports WTP-RPT-186, Rev 0, } \\
\text { WTP-RPT-188, Rev 0, and WTP-RPT-197, Rev 0. }\end{array}$ \\
\hline $\begin{array}{l}\text { 2. Determine the mineralogy of the precipitate phase, } \\
\text { precipitate composition, and the solution phase } \\
\text { saturation composition for the composite samples } \\
\text { from demonstration Test A. }\end{array}$ & $\begin{array}{l}\text { 2. This criterion was met by performing chemical } \\
\text { analysis using inductively coupled plasma (ICP) } \\
\text { spectroscopy and ion chromatography (IC) on the } \\
\text { solution and on the dissolved solids. The solids were } \\
\text { also analyzed by polarized light microscopy (PLM) } \\
\text { and X-ray diffraction (XRD), and three of them were } \\
\text { found to be sodium phosphate, and one of them was } \\
\text { found to be sodium oxalate with all analytical } \\
\text { methods being in agreement. These results are } \\
\text { discussed further in Section } 3.0 .\end{array}$ \\
$\begin{array}{ll}\text { Determine the rate at which the anions-phosphate, } \\
\text { oxalate, sulfate, silicate, and fluoride-approach } \\
\text { equilibrium solution composition (saturation } \\
\text { concentration) in post-caustic-leach slurry at } 25^{\circ} \mathrm{C} \\
\text { before filtration. }\end{array}$ & $\begin{array}{l}\text { 3. The criterion was met by preparing 11 different } \\
\text { synthetic caustic leachate blends of the target anions } \\
\text { from UFP-2 that were prepared by spiking different } \\
\text { anions to a higher concentration before beginning the } \\
\text { test. These were then heated to } 85^{\circ} \mathrm{C}, \text { held at } 85^{\circ} \mathrm{C} \\
\text { for } 24 \text { hours, cooled to } 25^{\circ} \mathrm{C} \text {, and then held for }\end{array}$ \\
\hline
\end{tabular}


Table S.3. Results and Performance Against Success Criteria of TP-WTP-PEP-044, Rev 0.2

\begin{tabular}{|c|c|}
\hline List Success Criteria & $\begin{array}{l}\text { Explain How the Tests Did or Did Not } \\
\text { Meet the Success Criteria }\end{array}$ \\
\hline & $\begin{array}{l}24 \text { hours. The samples were then cooled to } 16^{\circ} \mathrm{C} \text {, } \\
\text { held for } 24 \text { hours, heated back to } 25^{\circ} \mathrm{C} \text {, and then held } \\
96 \text { hours. The solutions were sampled periodically } \\
\text { throughout the test and analyzed for the presence of } \\
\text { these anions. These results showed that oxalate } \\
\text { appears to be fairly slow to precipitate, taking nearly } \\
24 \text { hours before reaching equilibrium. The presence } \\
\text { of phosphate, sulfate, or fluoride did not significantly } \\
\text { change the equilibrium concentration of oxalate, but } \\
\text { the kinetics appears to be faster in the presence of the } \\
\text { other anions. In the absence of fluoride, phosphate } \\
\text { appears to equilibrate very quickly. However, in the } \\
\text { presence of fluoride, phosphate equilibrates much } \\
\text { slower and to a significantly lower solubility limit. } \\
\text { Phosphate solubility appears to be a strong function } \\
\text { of fluoride. The presence of fluoride does appear to } \\
\text { impact the sulfate solubility. Interestingly, fluoride } \\
\text { appears to equilibrate fairly quickly. The presence of } \\
\text { oxalate appears to impact the fluoride solubility, but } \\
\text { fluoride did not impact the oxalate solubility. These } \\
\text { results are discussed further in Section 4.0. }\end{array}$ \\
\hline $\begin{array}{l}\text { 4. Identify precipitates formed at ambient temperature } \\
\text { in the presence of phosphate, oxalate, sulfate, } \\
\text { silicate, and fluoride anions in the post-caustic } \\
\text { leachate solution. Also, determine particle-size } \\
\text { distribution (PSD), crystal shape and habit } \\
\text { (morphology), quantity, and the settling rate of } \\
\text { precipitates formed. }\end{array}$ & $\begin{array}{l}\text { 4. This criterion was met by preparing } 11 \text { different } \\
\text { blends (which corresponded to the supernate } \\
\text { concentration of those in Success Criterion } 3 \text { ) of the } \\
\text { target anions that were prepared and held at } 35^{\circ} \mathrm{C} \text { for } \\
24 \text { hours and filtered. Then the supernate was cooled } \\
\text { to } 20^{\circ} \mathrm{C} \text { and held for } 96 \text { hours. The objective of this } \\
\text { task was to collect precipitate samples for physical } \\
\text { and chemical characterization. Five of the } 11 \text { tests } \\
\text { produced precipitate, which was then analyzed to } \\
\text { determine PSD crystal shape and habit (morphology), } \\
\text { quantity, and the settling rate of precipitates formed. } \\
\text { These results showed that four of the precipitates } \\
\text { were sodium fluoride phosphates, and one precipitate } \\
\text { was sodium phosphate. No oxalate, sulfate, or } \\
\text { silicate solids were observed. The solids settled } \\
\text { fairly quickly. These results are discussed further in } \\
\text { Section 5.0. }\end{array}$ \\
\hline $\begin{array}{l}\text { 5. Determine the dilution required to redissolve the } \\
\text { post-filtration precipitate through incremental } \\
\text { dilution of the slurry with water at } 25^{\circ} \mathrm{C} \text {. }\end{array}$ & $\begin{array}{l}\text { 5. This criterion was met by testing seven samples from } \\
\text { the PEP Integrated Tests (A, B, and D). A total of } \\
100-\mathrm{mL} \text { of solution with precipitate in it was placed } \\
\text { in a centrifuge tube and diluted with 5-mL DIW each }\end{array}$ \\
\hline
\end{tabular}


Table S.3. Results and Performance Against Success Criteria of TP-WTP-PEP-044, Rev 0.2

\begin{tabular}{|c|c|}
\hline List Success Criteria & $\begin{array}{l}\text { Explain How the Tests Did or Did Not } \\
\text { Meet the Success Criteria }\end{array}$ \\
\hline & $\begin{array}{l}\text { day until the precipitate completely dissolved. The } \\
\text { amount of solids remaining was measured each day } \\
\text { by centrifuging at } 1000 \mathrm{G} \text { for } 15 \text { minutes and } \\
\text { recording the volume of solids present. More DIW } \\
\text { was added, and the solids were resuspended. These } \\
\text { results showed that the solids are essentially soluble } \\
\text { if enough DIW is added. These results are discussed } \\
\text { further in Section 6.0. }\end{array}$ \\
\hline $\begin{array}{l}\text { Determine solution supersaturation in the } \\
\text { post-caustic-leach filtrate during the dewatering } \\
\text { period, based on the samples collected at discrete } \\
\text { times during Integrated Test B in the PEP. The } \\
\text { supersaturation shall be expressed as both the } \\
\text { centrifuged volume fraction and as weight fraction } \\
\text { of the slurry sample. Also, determine the } \\
\text { temperature at which the precipitate goes into total } \\
\text { solution. }\end{array}$ & $\begin{array}{l}\text { 6. This criterion was met by placing } \\
10 \text { post-caustic-leach filtrate and wash solutions from } \\
\text { the PEP Integrated Test } \mathrm{B} \text { in an incubator at } 20^{\circ} \mathrm{C} \text { for } \\
96 \text { hours. The temperature of the incubator was } \\
\text { raised } 1^{\circ} \mathrm{C} \text { each day up to } 35^{\circ} \mathrm{C} \text {. Samples were taken } \\
\text { at } 20^{\circ} \mathrm{C}, 25^{\circ} \mathrm{C} \text {, and } 35^{\circ} \mathrm{C} \text {. Some of the precipitate did } \\
\text { not dissolve even at } 35^{\circ} \mathrm{C} \text {. These results showed that } \\
\text { in the more concentrated solutions, it was phosphate } \\
\text { dissolving, and in the more dilute solutions, it was } \\
\text { oxalate dissolving. The solids remaining were } \\
\text { determined to be sodium oxalate in all but one } \\
\text { sample, which was sodium phosphate. These results } \\
\text { are discussed further in Section 7.0. }\end{array}$ \\
\hline $\begin{array}{l}\text { 7. Determine the effects of blending on precipitation } \\
\text { during the post-caustic-leach dewatering and wash } \\
\text { periods in Integrated Test B in the PEP. }\end{array}$ & $\begin{array}{l}\text { 7. This criterion was met by preparing five different } \\
\text { blends from the PEP Integrated Test B } \\
\text { post-caustic-leach dewatering and wash solutions to } \\
\text { determine if precipitate formed after } 48 \text { hours at } \\
25^{\circ} \mathrm{C} \text {. } \\
\text { It was found that the blends containing leachate and } \\
\text { permeate all formed precipitate almost immediately } \\
\text { whereas the blends containing just wash solutions did } \\
\text { not precipitate during this time period at this } \\
\text { temperature. These results are discussed further in } \\
\text { Section } 8.0 \text {. }\end{array}$ \\
\hline
\end{tabular}

\section{Quality Requirements}

The Pacific Northwest National Laboratory (PNNL) Quality Assurance Program is based upon the requirements as defined in the U.S. Department of Energy (DOE) Order 414.1C, Quality Assurance and 10 CFR 830, Energy/Nuclear Safety Management, Subpart A-Quality Assurance Requirements (a.k.a. 
the Quality Rule). PNNL has chosen to implement the following consensus standards in a graded approach:

- ASME NQA-1-2000, Quality Assurance Requirements for Nuclear Facility Applications, Part 1, Requirements for Quality Assurance Programs for Nuclear Facilities.

- ASME NQA-1-2000, Part II, Subpart 2.7, Quality Assurance Requirements for Computer Software for Nuclear Facility Applications.

- ASME NQA-1-2000, Part IV, Subpart 4.2, Graded Approach Application of Quality Assurance Requirements for Research and Development.

The procedures necessary to implement the requirements are documented through PNNL's "How Do I...?" (HDI). ${ }^{\text {(a) }}$

PNNL implements the RPP-WTP quality requirements by performing work in accordance with the River Protection Project-Waste Treatment Plant Support Program (RPP-WTP) Quality Assurance Plan (RPP-WTP-QA-001, QAP). Work was performed to the quality requirements of NQA-1-1989 Part I, Basic and Supplementary Requirements, NQA-2a-1990, Part 2.7 and DOE/RW-0333P, Rev 13, Quality Assurance Requirements and Descriptions (QARD), as applicable. These quality requirements are implemented through the River Protection Project-Waste Treatment Plant Support Program (RPP-WTP) Quality Assurance Manual (RPP-WTP-QA-003, QAM). The requirements of DOE/RW-0333P Rev 13, Quality Assurance Requirements and Descriptions (QARD), and 10 CFR 830, Subpart A, were not required for this work.

RPP-WTP addresses internal verification and validation activities by conducting an independent technical review of the final data report in accordance with RPP-WTP's procedure QA-RPP-WTP-604. This review procedure is part of PNNL's RPP-WTP Quality Assurance Manual (RPP-WTP-QA-003). Following this procedure, a technical review would verify that the reported results are traceable, that inferences and conclusions are soundly based, and the reported work satisfies the objectives.

\section{R\&T Test Conditions}

The research and technology (R\&T) test conditions, as defined in the Test Specifications 24590-PTF-TSP-RT-07-001, Rev 2 (Huckaby 2008) associated with Test Plan TP-WTP-PEP-044, Rev 0.2 are summarized in Table S.4.

(a) PNNL's system for managing the delivery of laboratory-level policies, requirements, and procedures. 
Table S.4. R\&T Test Conditions from TP-WTP-PEP-044, Rev 0.2

\begin{tabular}{|c|c|}
\hline List R\&T Test Conditions & Were Test Conditions Followed? \\
\hline $\begin{array}{l}\text { 1) Filter flux measurements will be conducted on two } \\
\text { low-solids concentration simulants and on two } \\
\text { high-solids concentration simulants to demonstrate the } \\
\text { scale-up of crossflow filtration. }\end{array}$ & $\begin{array}{l}\text { Not applicable to this report. It is addressed } \\
\text { in report RPT-WTP-203, Rev } 0 .\end{array}$ \\
\hline $\begin{array}{l}\text { 2) Caustic-leaching tests will be performed with slurry } \\
\text { samples collected from the PEP leaching vessels just } \\
\text { before steam heating is initiated in the PEP to obtain } \\
\text { laboratory caustic-leaching data that can be used as a } \\
\text { baseline to evaluate caustic-leaching performance in } \\
\text { the PEP. }\end{array}$ & $\begin{array}{l}\text { Not applicable to this report. It is addressed } \\
\text { in report RPT-WTP-200, Rev } 0 \text {. }\end{array}$ \\
\hline $\begin{array}{l}\text { 3) Oxidative leaching tests will be performed with slurry } \\
\text { samples collected from the PEP leaching vessels just } \\
\text { before the permanganate is added in the PEP to obtain } \\
\text { laboratory oxidative leaching data that can be used as a } \\
\text { baseline to evaluate oxidative leaching performance in } \\
\text { the PEP. }\end{array}$ & $\begin{array}{l}\text { Not applicable to this report. It is addressed } \\
\text { in report RPT-WTP-200, Rev } 0 .\end{array}$ \\
\hline $\begin{array}{l}\text { 4) Permeate precipitation testing will be conducted using } \\
\text { the post-caustic wash solutions, the permeate near the } \\
\text { end of the initial solids concentration process, and the } \\
\text { permeate near the end of the post-caustic-leach solids } \\
\text { concentration process to evaluate the propensity of the } \\
\text { simulant permeates to precipitate solids. }\end{array}$ & $\begin{array}{l}\text { Not applicable to this report. It is addressed } \\
\text { in report RPT-WTP-200, Rev } 0 .\end{array}$ \\
\hline $\begin{array}{l}\text { 5) Permeate precipitation tests will be performed to } \\
\text { determine the operating bounds in concentration and } \\
\text { temperature to avoid post-filtration precipitation in the } \\
\text { caustic-leach process and to assess a need for a change } \\
\text { to the flowsheet to improve process operability using } \\
\text { caustic leach and wash solutions collected during PEP } \\
\text { Integrated Tests A, B, and D. }\end{array}$ & $\begin{array}{l}\text { The test conditions were followed by } \\
\text { characterizing the washes and precipitates, } \\
\text { diluting the wash solutions with } 5 \text { vol } \% \\
\text { DIW every } 24 \text { hours, raising the } \\
\text { temperatures by } 1{ }^{\circ} \mathrm{C} \text { per } 24 \text { hours from } 20^{\circ} \mathrm{C} \\
\text { to } 35^{\circ} \mathrm{C} \text {, and blending different solutions as } \\
\text { discussed in Sections } 3,6,7 \text {, and } 8 \text {, } \\
\text { respectively. A simplified simulant spiked } \\
\text { with the anions of interest was also used and } \\
\text { heated to } 85^{\circ} \mathrm{C} \text { for } 24 \text { hours, cooled to } 25^{\circ} \mathrm{C} \\
\text { for } 24 \text { hours, cooled to } 16^{\circ} \mathrm{C} \text { for } 24 \text { hours, } \\
\text { and then heated to } 25^{\circ} \mathrm{C} \text { again for } 96 \text { hours } \\
\text { as discussed in Section } 4 \text {. Another test was } \\
\text { performed with the same spiked simulant by } \\
\text { heating to } 35^{\circ} \mathrm{C} \text { for } 46 \text { hours and then } \\
\text { filtering and cooling to } 20^{\circ} \mathrm{C} \text { for } 96 \text { hours as } \\
\text { discussed in Section } 5 \text {. }\end{array}$ \\
\hline
\end{tabular}




\section{Simulant Use}

Testing for Tasks 2 and 3 of the Test Exception 24590-WTP-TEF-RT-09-0001, Rev 1 used a base simplified simulant (derived from PEP Integrated Test A) that contained simulant solids made up of the filtration sludge and a supernate containing sufficient aluminate to represent dissolved gibbsite/boehmite, nitrate, nitrite, carbonate, and hydroxide only. The composition of the base simulant was based on UFP-1 leaching conditions.

Testing for Tasks 1, 4, 5, and 6 used caustic leach and wash solution samples provided by WTP from the PEP Integrated Tests A, B, and D. Integrated Test A corresponded to caustic leaching in the UFP-1 vessel, and Integrated Tests B and D corresponded to caustic leaching in the UFP-2 vessel.

The simulant used for the PEP tests does not represent any particular Hanford tank waste type or a blend of Hanford tank wastes. The simulant used for the PEP testing was blended from components listed below (Barnes and Voke 2006). The simulant recipe for Phase I PEP testing did not include phosphate simulant. The basis for selecting the individual components and the comparison to actual waste behavior is provided where applicable in the indicated references.

- Boehmite component (for Al) (Russell et al. 2009a)

- Gibbsite component (for Al) (Russell et al. 2009b)

- Oxalate component (Barnes and Voke 2006)

- Filtration Inerts component (Russell et al. 2009c)

- Supernatant component (Barnes and Voke 2006)

- Chromium component (Rapko et al. 2007).

\section{Discrepancies and Follow-on Tests}

None. 



\subsection{Background}

Pacific Northwest National Laboratory (PNNL) has been tasked by Bechtel National Inc. (BNI) on the River Protection Project-Hanford Tank Waste Treatment and Immobilization Plant (RPP-WTP) project to perform research and development activities to resolve technical issues identified for the Pretreatment Facility (PTF). The Pretreatment Engineering Platform (PEP) was designed, constructed, and operated as part of a plan to respond to issue M12, "Undemonstrated Leaching Processes," of the External Flowsheet Review Team (EFRT) issue response plan (Barnes et al. 2006). The PEP is a 1/4.5-scale test platform designed to simulate the WTP pretreatment caustic leaching, oxidative leaching, ultrafiltration solids concentration, and slurry washing processes. The PEP replicates the WTP leaching processes using prototypic equipment and control strategies. A simplified flow diagram of the PEP system is shown in Figure 1.1.

Two operating scenarios are being evaluated for the ultrafiltration process (UFP) and leaching operations. The first scenario has caustic leaching performed in the UFP-2 ultrafiltration feed vessels (i.e., vessel UFP-VSL-T02A in the PEP; and vessels UFP-VSL-00002A and B in the WTP PTF). The second scenario has caustic leaching conducted in the UFP-1 ultrafiltration feed preparation vessels (i.e., vessels UFP-VSL-T01A and B in the PEP; vessels UFP-VSL-00001A and B in the WTP PTF).

In both scenarios, 19-M sodium hydroxide solution ( $\mathrm{NaOH}$, caustic) is added to the waste slurry in the vessels to leach solid aluminum compounds (e.g., gibbsite, boehmite). Caustic addition is followed by a heating step that uses direct injection of steam to accelerate the leach process. Following the caustic leach, the vessel contents are cooled using vessel cooling jackets and/or external heat exchangers. The main difference between the two scenarios is that for leaching in UFP-VSL-T01A and B, the 19-M NaOH is added to feed waste slurry ( 3 to 8 -wt\% solids), while for leaching in UFP-VSL-T02A, the slurry is concentrated to nominally 20 -wt $\%$ solids using crossflow ultrafiltration before adding the caustic.

The PEP testing program was conducted under Test Plan TP-RPP-WTP-506 ${ }^{(\mathrm{a})}$ using a waste simulant that was developed in response to Task 5 from the M-12 EFRT issue response plan ${ }^{(b)}$. The testing included the following tests with the PEP simulant:

- Shakedown/Functional Testing: Tested process operations (e.g., slurry transfers, steam heating of the vessels and the accumulation of condensate, filter backpulsing, and flushing), process controls (e.g., transmembrane pressure and axial flow velocity in the filter loop), certain test functions (e.g., in-line slurry sampling accuracy and precision).

- Integrated Test A: Demonstrated integrated processing when caustic leaching $\left(98^{\circ} \mathrm{C}\right)$ is performed in UFP-VSL-00001A/B with the Cr simulant component added after the post-caustic-leach washing step.

- Integrated Test B: Demonstrated integrated processing when the caustic leaching $\left(98^{\circ} \mathrm{C}\right)$ is performed in UFP-VSL-00002A with the Cr simulant component added after the post-caustic-leach washing step.

(a) GB Josephson, OP Bredt, JK Young, and DE Kurath. 2008. Pretreatment Engineering Platform (PEP) Testing(Phase I). TP-RPP-WTP-506, Rev 0.4, Pacific Northwest National Laboratory, Richland, Washington.

(b) RD Scheele, GN Brown, and DE Kurath. 2009. Scale-Up, Production, and Procurement of PEP Simulants. WTP-RPT-204, Rev 0, Pacific Northwest National Laboratory, Richland Washington. 
- Integrated Test D: Demonstrated integrated processing when the caustic leaching is performed at a lower temperature $\left(85^{\circ} \mathrm{C}\right)$ in UFP-VSL-00002A and with the $\mathrm{Cr}$ simulant component added to the initial batch of simulant.

Integrated Test $\mathrm{C}$ was deleted from the scope of the testing (ICN-TP-RPP-WTP-506_R0.2).

Whether caustic leaching was carried out in UFP-VSL-T01A/B or UFP-VSL-T02A, the leached solids wash steps occurred in vessel UFP-VSL-T02A and used the same procedure. Periodically, measured volumes of inhibited water (IW) $(0.01 \mathrm{M} \mathrm{NaOH})$ were added incrementally upstream of the first recirculation pump and mixed inline. At the same time, permeate was removed from the ultrafilters in the loop and collected in UFP-VSL-T62A and/or UFP-VSL-T62B. The wash liquid addition line flowmeter was used to monitor and control the wash volume.

Significant post-filtration precipitation was observed in the post-caustic leachate and wash solutions while the leaching and ultrafiltration processes were demonstrated in the PEP. Precipitation in these streams could lead to precipitates accumulating in filtrate receipt vessels and in the feed to ion exchange columns. Post-filtration precipitation in the feed to the ion-exchange column will have a very significant effect on the operability of the unit and the pretreatment process. Therefore, it is essential to develop an understanding of the post-filtration-precipitation phenomenon.

The test objective was divided into several tasks to develop an understanding of the post-filtration-precipitation phenomenon. The post-filtration precipitate mineralogy, precipitate phase compositions, and solution saturation compositions in the post-caustic leachate and wash solution samples from Integrated Test A are described in Section 3. The rate at which the anions approach equilibrium solution composition upon cooling in the post-caustic-leach slurry is discussed in Section 4 of this report. Section 5 identifies and characterizes the precipitates formed in the post-caustic leachate solution through controlled laboratory experiments. Section 6 describes the potential to redissolve the post-filtration precipitate in Integrated Tests A, B, and D in the PEP through dilution with water. Determination of solution supersaturation in the post-caustic-leach filtrate during the dewatering and washing period based on the samples collected during Integrated Test B in the PEP is described in Section 7. The effects of blending during the post-caustic-leach dewatering and wash periods in Integrated Test B in the PEP are discussed in Section 8. 


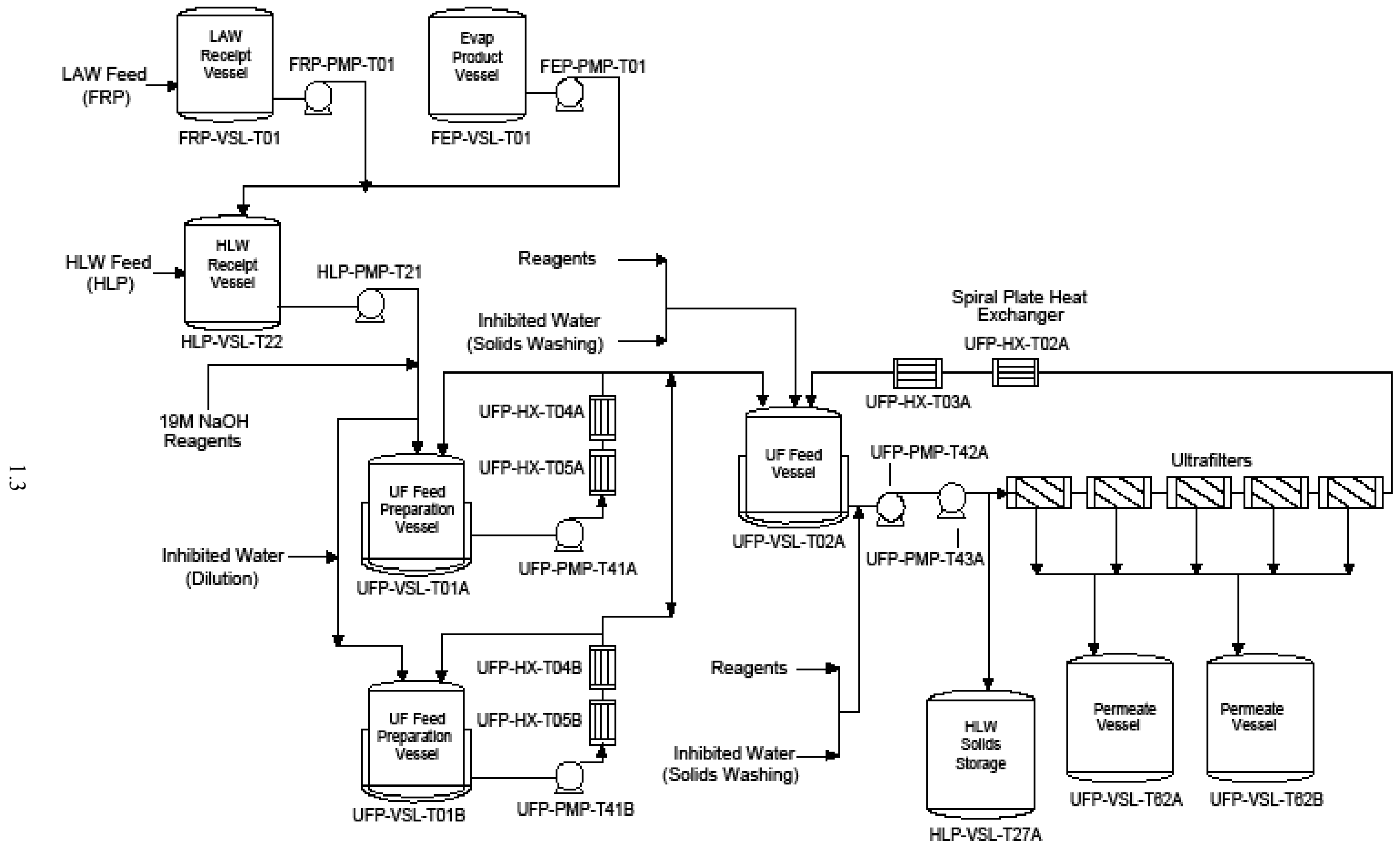

Figure 1.1. PEP Simplified Flow Diagram 



\subsection{Quality Assurance}

The PNNL Quality Assurance Program is based upon the requirements as defined in the U.S. Department of Energy (DOE) Order 414.1C, Quality Assurance and 10 CFR 830, Energy/Nuclear Safety Management, Subpart A-Quality Assurance Requirements (a.k.a. the Quality Rule). PNNL has chosen to implement the following consensus standards in a graded approach:

- ASME NQA-1-2000, Quality Assurance Requirements for Nuclear Facility Applications, Part 1, Requirements for Quality Assurance Programs for Nuclear Facilities.

- ASME NQA-1-2000, Part II, Subpart 2.7, Quality Assurance Requirements for Computer Software for Nuclear Facility Applications.

- ASME NQA-1-2000, Part IV, Subpart 4.2, Graded Approach Application of Quality Assurance Requirements for Research and Development.

The procedures necessary to implement the requirements are documented through PNNL's "How Do I...?" (HDI). ${ }^{\text {(a) }}$

PNNL implements the RPP-WTP quality requirements by performing work in accordance with the River Protection Project-Waste Treatment Plant Support Program (RPP-WTP) Quality Assurance Plan (RPP-WTP-QA-001, QAP). Work was performed to the quality requirements of NQA-1-1989, Part I, Basic and Supplementary Requirements, NQA-2a-1990, Part 2.7, and DOE/RW-0333P, Rev 13, Quality Assurance Requirements and Descriptions (QARD) as applicable. These quality requirements are implemented through the River Protection Project-Waste Treatment Plant Support Program (RPP-WTP) Quality Assurance Manual (RPP-WTP-QA-003, QAM). The requirements of DOE/RW-0333P Rev 13, Quality Assurance Requirements and Descriptions (QARD), and 10 CFR 830, Subpart A, were not required for this work.

The applicable quality control (QC) parameters for chemical analysis and the acceptance criteria are delineated in Table 2.1. Blank spike and/or laboratory control sample QC failures will result in reanalyzing the sample for the particular analyte for which the spike failed. Matrix spike and/or duplicate analysis QC failures will not result in reanalyzing the sample, but probable reasons for the failure will be discussed in the analytical report to be stored in the project files.

RPP-WTP addresses internal verification and validation activities by conducting an independent technical review of the final data report in accordance with RPP-WTP's procedure QA-RPP-WTP-604. This review procedure is part of PNNL's RPP-WTP Quality Assurance Manual (RPP-WTP-QA-003). Following this procedure, a technical review would verify that the reported results are traceable, that inferences and conclusions are soundly based, and the reported work satisfies the objectives.

(a) PNNL's system for managing the delivery of laboratory-level policies, requirements, and procedures. 
Table 2.1. QC Acceptance Criteria

\begin{tabular}{|c|c|}
\hline QC Sample & $\begin{array}{l}\text { QC Acceptance } \\
\text { Criteria }\end{array}$ \\
\hline Processing Blanks & $\begin{array}{l}<\text { EQL (estimated } \\
\text { quantitation limit) }\end{array}$ \\
\hline Duplicate (Precision) & $\leq 20 \%$ \\
\hline $\begin{array}{l}\text { Laboratory Control Sample (LCS) } \\
\text { /Blank Spike (BS) }\end{array}$ & $80 \%$ to $120 \%$ \\
\hline Matrix Spike (Accuracy) & None prepared \\
\hline Post Spike (Accuracy) & $75 \%$ to $125 \%$ \\
\hline Serial Dilution & $\leq 10 \%$ \\
\hline System QC Samples & $90 \%$ to $110 \%$ \\
\hline
\end{tabular}




\subsection{Post-Filtration Precipitate and Solution Characterizations}

The objective of these tests was to determine the post-filtration precipitate mineralogy, precipitate phase compositions, and the solution saturation compositions in the post-caustic leachate and wash solution samples from the PEP Integrated Test A at ambient temperature. These tests were specified in Test Exception WTP-TEF-RT-09-0001, Rev 1, Task 1, associated with Test Plan TP-WTP-PEP-044, Rev 0.2 .

In the PEP Integrated Test A, the concentrated caustic-leached solids in UFP-VSL-T02A were washed incrementally with $0.01 \mathrm{M} \mathrm{NaOH}$. The wash solution was added in 100 incremental steps. Each step had a target volume of 11 gallons. A 1-L sample was taken from the line carrying the permeate stream from the first ultrafilter to the pulse-pot, which represented each wash step for a total of 100 samples. The wash steps occurred in tank UFP-VSL-T02A, which contained the leached and concentrated slurry, by periodically adding a small volume of inhibited water (IW, $0.01 \mathrm{M} \mathrm{NaOH}$ ) upstream of the first recirculation pump and mixing inline. At the same time, permeate was removed from the ultrafilters in the loop and collected in UFP-VSL-T62A and/or UFP-VSL-T62B. The flowmeter for the line where wash liquid is added was used to monitor and control the wash volume.

During every third wash step, an anti-foam agent (AFA) was added to maintain a target concentration of $350 \mathrm{ppm}$. Wash liquid additions were initiated when the level in vessel UFP-VSL-T02A dropped below a set value occurring approximately every 4 minutes, except between batches 7 and 8 . Between batches 7 and 8 , there was a 14-hr hold time to address recirculation pump problems. Following each addition, the slurry and wash liquid were recirculated and therefore mixed continuously while permeate was continuously removed at a rate between $4-\mathrm{kg} / \mathrm{min}$ and $17-\mathrm{kg} / \mathrm{min}$ by ultrafiltration through all five filter bundles.

The caustic-leach wash samples were collected from February 14, 2009, 1:13 until February 15, 2009 22:50. All 100 samples were stored at ambient temperature of the Process Development Laboratory-West (PDL-W) facility and were then transferred to the Applied Process Engineering Laboratory (APEL) on February 17, 2009. These samples were stored at room temperature of the APEL $\left(\sim 18-22^{\circ} \mathrm{C}\right)$ for 13 to 14 days. Samples 2341 (wash 3), 2349 (wash 11), 2363 (wash 25), and 2369 (wash 31) were chosen for further characterization and all contained precipitates that were then separated from the supernate by vacuum filtration using a $0.45-\mu \mathrm{m}$ filter on March 2-3, 2009, in the APEL.

Even after filtering, the samples continued to form precipitate over time. Therefore, these four samples $\left(2341,2349,2363\right.$, and 2369) were placed in an oven at $38.4^{\circ} \mathrm{C}$ on June $8,2009,17: 30$ until June 11, 2009, 9:30 to allow the precipitate to redissolve. After the precipitate had redissolved, supernate samples were taken at approximately $38^{\circ} \mathrm{C}$ for chemical analysis and density measurement after filtering.

Samples 2341 (wash 3), 2349 (wash 11), 2363 (wash 25), and 2369 (wash 31) were analyzed by inductively coupled plasma (ICP) spectroscopy for Al, Na, P, and S (shown in Table 3.1) and ion chromatography (IC) for oxalate, phosphate, sulfate, nitrate, and nitrite (shown in Table 3.2) to determine the solution saturation compositions as well as supernate density and hydroxide concentration (shown in Table 3.3). The chemical analysis and density measurements were performed at room temperature. The 
chemical analysis involved dissolving any precipitates that may have formed, and the density measurements ignored any precipitates that may have formed.

Table 3.1. ICP Results for Integrated Test A Post-Caustic Wash Solutions Composition

\begin{tabular}{cccccc}
\hline Sample ID & Wash \# & $\begin{array}{c}\mathrm{Al} \\
(\mu \mathrm{g} / \mathrm{g})\end{array}$ & $\begin{array}{c}\mathrm{Na} \\
(\mu \mathrm{g} / \mathrm{g})\end{array}$ & $\begin{array}{c}\mathrm{P} \\
(\mu \mathrm{g} / \mathrm{g})\end{array}$ & $\begin{array}{c}\mathrm{S} \\
(\mu \mathrm{g} / \mathrm{g})\end{array}$ \\
\hline 2341 & 3 & 7,710 & 117,000 & 586 & 2,700 \\
2349 & 11 & 5,840 & 91,800 & 744 & 2,060 \\
2363 & 25 & 4,060 & 63,900 & 1,500 & 1,370 \\
2369 & 31 & 3,200 & 54,000 & 1,950 & 1,140 \\
\hline
\end{tabular}

Table 3.2. IC Results for Integrated Test A Post-Caustic Wash Solutions Composition

\begin{tabular}{ccccccc}
\hline Sample ID & Wash \# & $\begin{array}{c}\mathrm{C}_{2} \mathrm{O}_{4} \\
(\mu \mathrm{g} / \mathrm{g})\end{array}$ & $\begin{array}{c}\mathrm{PO}_{4} \\
(\mu \mathrm{g} / \mathrm{g})\end{array}$ & $\begin{array}{c}\mathrm{SO}_{4} \\
(\mu \mathrm{g} / \mathrm{g})\end{array}$ & $\begin{array}{c}\mathrm{NO}_{3} \\
(\mu \mathrm{g} / \mathrm{g})\end{array}$ & $\begin{array}{c}\mathrm{NO}_{2} \\
(\mu \mathrm{g} / \mathrm{g})\end{array}$ \\
\hline 2341 & 3 & 242 & 1,530 & 7,810 & 47,100 & 10,900 \\
2349 & 11 & 622 & 2,250 & 6,020 & 36,100 & 8,280 \\
2363 & 25 & 1,750 & 4,990 & 4,140 & 24,700 & 5,670 \\
2369 & 31 & 2,500 & 6,370 & 3,360 & 20,000 & 4,620 \\
\hline
\end{tabular}

Table 3.3. Density Results for Integrated Test A Post-Caustic Wash Solutions Composition

\begin{tabular}{cccc}
\hline Sample ID & Wash \# & $\begin{array}{c}\text { Density } \\
(\mathrm{g} / \mathrm{mL})\end{array}$ & $\begin{array}{c}\mathrm{OH} \\
(\mu \mathrm{g} / \mathrm{mL})\end{array}$ \\
\hline 2341 & 3 & 1.28 & $7.08 \mathrm{E}+04$ \\
2349 & 11 & 1.22 & $5.05 \mathrm{E}+04$ \\
2363 & 25 & 1.15 & $3.25 \mathrm{E}+04$ \\
2369 & 31 & 1.13 & $2.66 \mathrm{E}+04$ \\
\hline
\end{tabular}

The analytical results of the solution phase in Table 3.2 indicate that the sodium oxalate and sodium phosphate dissolved and increased in concentration throughout the washes whereas the other analytes decreased in concentration progressively during the post-caustic-leach wash. The progressive increase in the oxalate and phosphate concentrations during the wash period is attributed to redissolution of the precipitated oxalate and phosphate during the caustic-leach operation. The redissolution of precipitated oxalate was initially suppressed because of common ion effect from the higher concentration of sodium ions in solution. The phosphate dissolved and appeared earlier than the oxalate during the wash operation, until it was fully dissolved (after approximately 24 washes). The phosphate concentration in the wash solutions began to decrease subsequently as it was gradually diluted with each incremental wash. This is shown in Figure 3.1.

Table 3.4 shows the amount of solids present along with the wt $\%$ undissolved solids (UDS). Figure 3.2 shows the solids after they were air-dried. No solids are visible for sample 2369 since so few 
were present that they were all on the filter paper. Even after filtering, crystals continued to form in the supernate over the next couple of months as the samples sat at room temperature of the APEL

$\left(\sim 18-22^{\circ} \mathrm{C}\right)$. It should also be noted that phosphate is significantly more temperature sensitive as shown in Figure 5.6. Results shown in Section 5 indicate that a $5^{\circ} \mathrm{C}$ drop in temperature will result in the precipitation of only about $5 \%$ of the soluble oxalate. However, the same $5^{\circ} \mathrm{C}$ drop will result in the precipitation of about $40 \%$ of the soluble sodium phosphate.

A material balance based on the data presented in Table 3.7 (to be discussed later) is consistent with six waters of hydration for the solids measured in. Using this estimate of the waters of hydration, the solids found in samples 2341 (wash 3), 2349 (wash 11), and 2363 (wash 25) are all consistent with the precipitation of approximately $25 \%$ of the soluble phosphate. This quantity of precipitation would be consistent with the approximately $3^{\circ} \mathrm{C}$ temperature drop observed (from $25^{\circ} \mathrm{C}$ to $22^{\circ} \mathrm{C}$ upon storage in APEL). However, the quantity of solids formed in sample 2369 (wash 31 ) represents roughly $10 \%$ of the soluble oxalate. This is much greater than the expected $2 \%$ to $6 \%$ solids based on the observed temperature drop. The results suggest that the oxalate samples may have achieved more supersaturation than simply that due to temperature effects. This could possibly have been from the common ion effect of blending the streams in the shell side of the filter bundle.

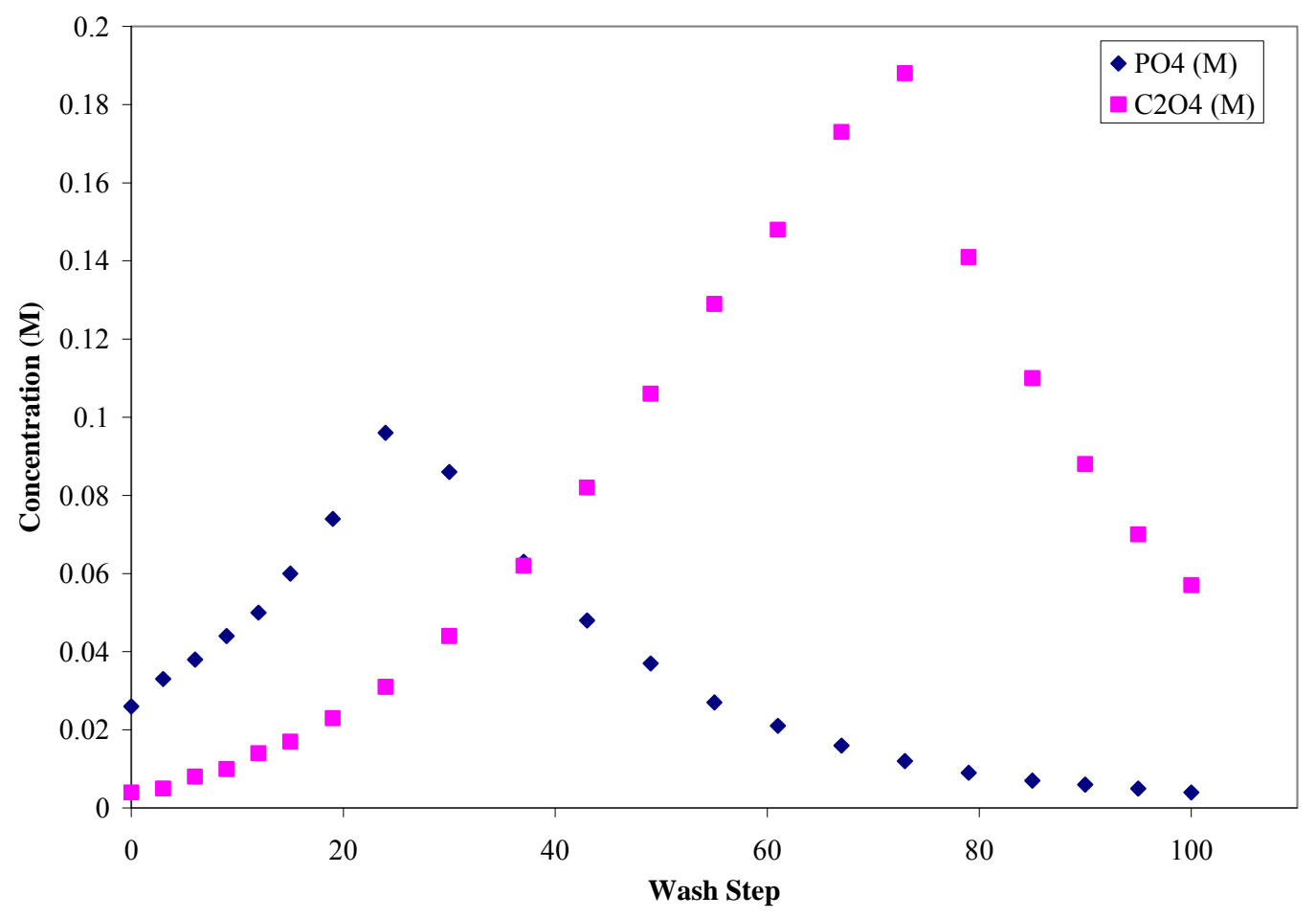

Figure 3.1. Phosphate and Oxalate Concentration Plot with PEP Integrated Test A Wash Step 
Table 3.4. Weights of Filtered Solids in Integrated Test A Samples

\begin{tabular}{cccc}
\hline & \multicolumn{3}{c}{ Weight of Solids } \\
Sample ID & Wash \# & $(\mathrm{g})$ & Wt\% UDS \\
\hline 2341 & 3 & 1.99 & 0.17 \\
2349 & 11 & 2.61 & 0.24 \\
2363 & 25 & 4.69 & 0.44 \\
2369 & 31 & 0.388 & 0.038 \\
\hline
\end{tabular}

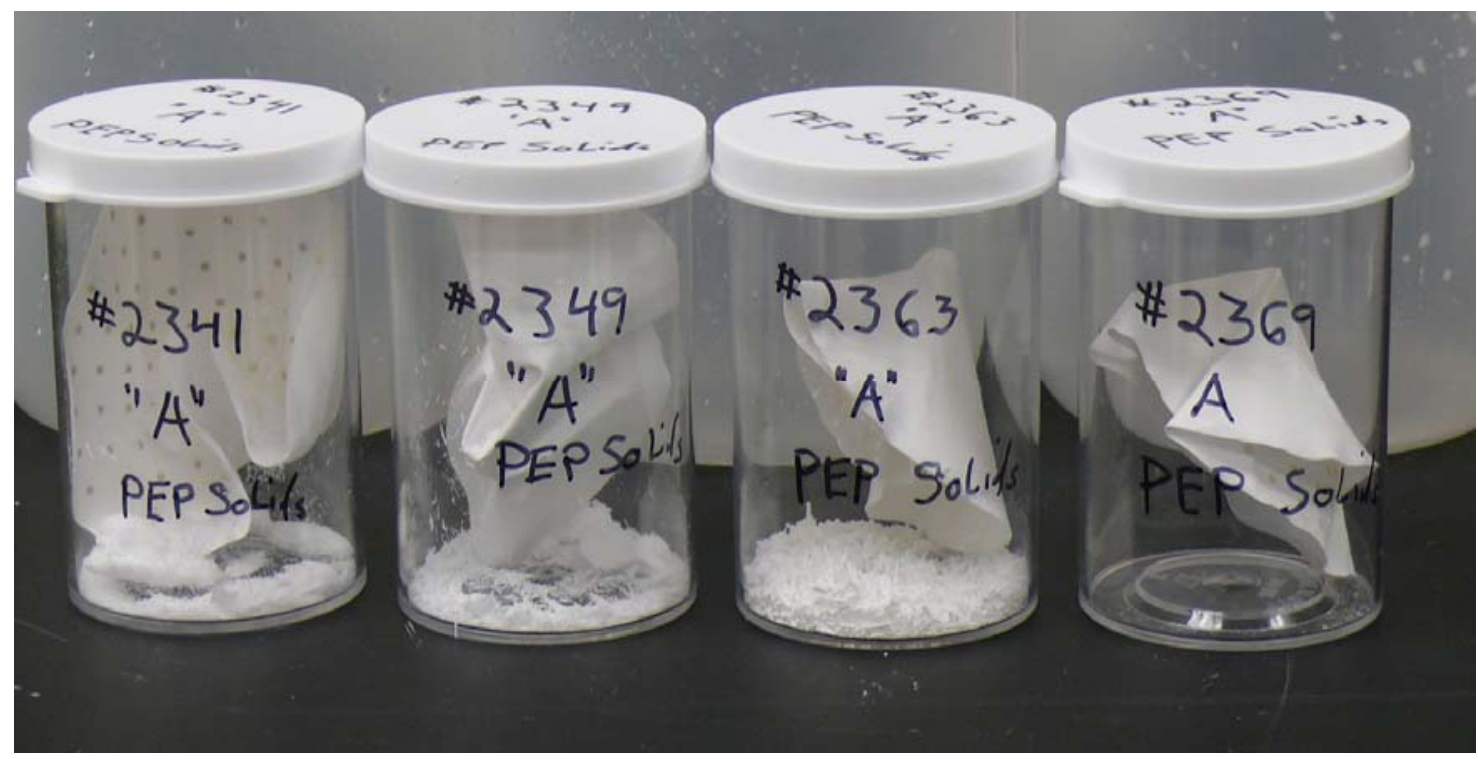

Figure 3.2. Filtered Solids and Filter Paper from the PEP Integrated Test A Samples Analyzed

The solids from this set of samples $(2341,2349,2363$, and 2369) were filtered and air dried, and the mineral form and approximate mean particle size of the solids were determined using polarized light microscopy (PLM). The mineral form was then confirmed using x-ray diffraction (XRD).

Pictures were taken of the samples in polarized light, cross-polarized light, and cross-polarized light with a full wave plate (which introduces a vivid red interference color to the image). Interference patterns were only obtained for samples 2341 (wash 3), 2349 (wash 11), and 2363 (wash 25), which were all determined to be sodium phosphate based on the crystal shape and color refraction. Sample 2369 (wash 31) indicated sodium oxalate based on the crystal shape. The microscope light source was unfiltered. These pictures are shown in Figure 3.3 through Figure 3.12. 


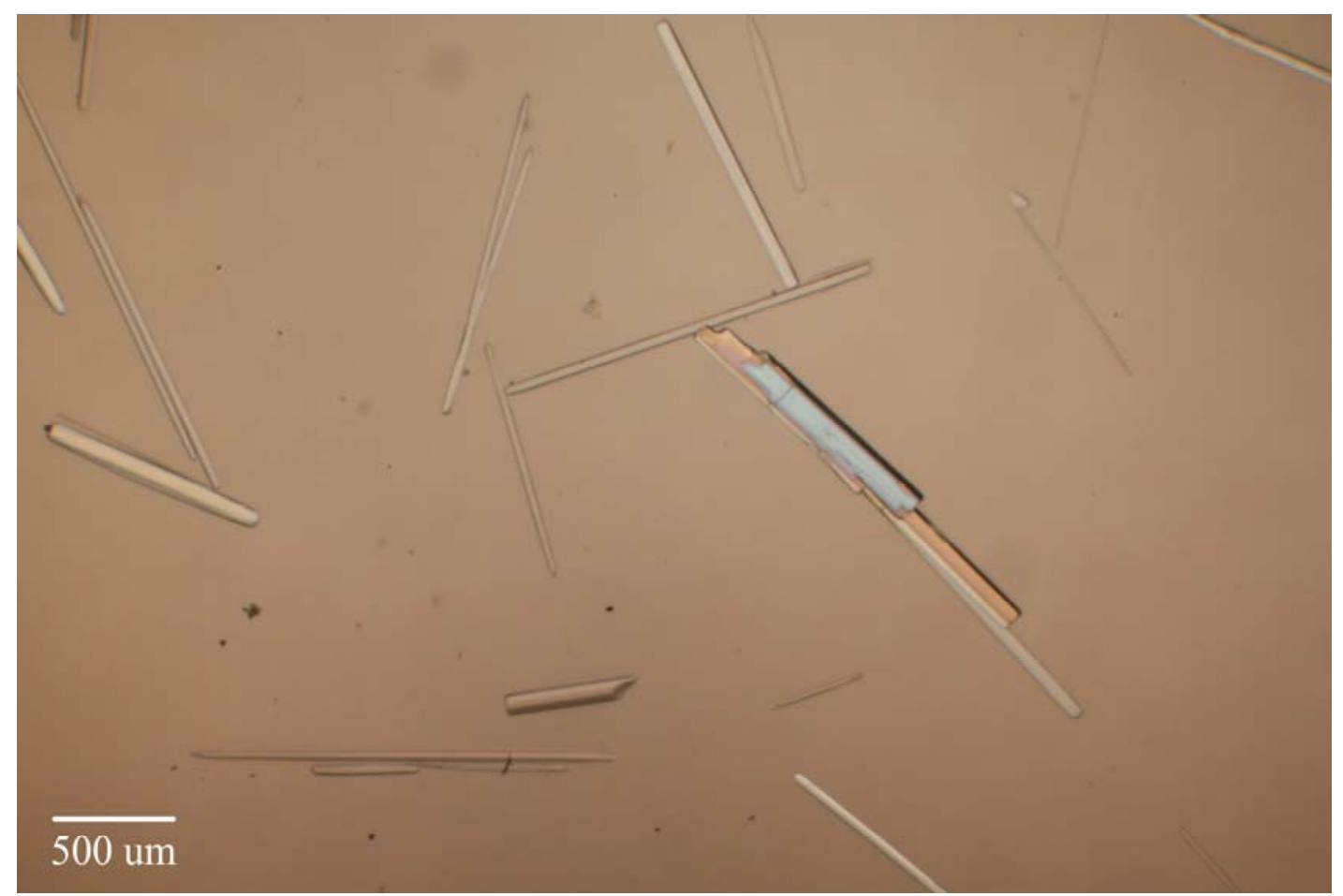

Figure 3.3. Polarized Light Optical Microscopy (OM) of Sodium Phosphate in Sample 2341 (Wash 3)

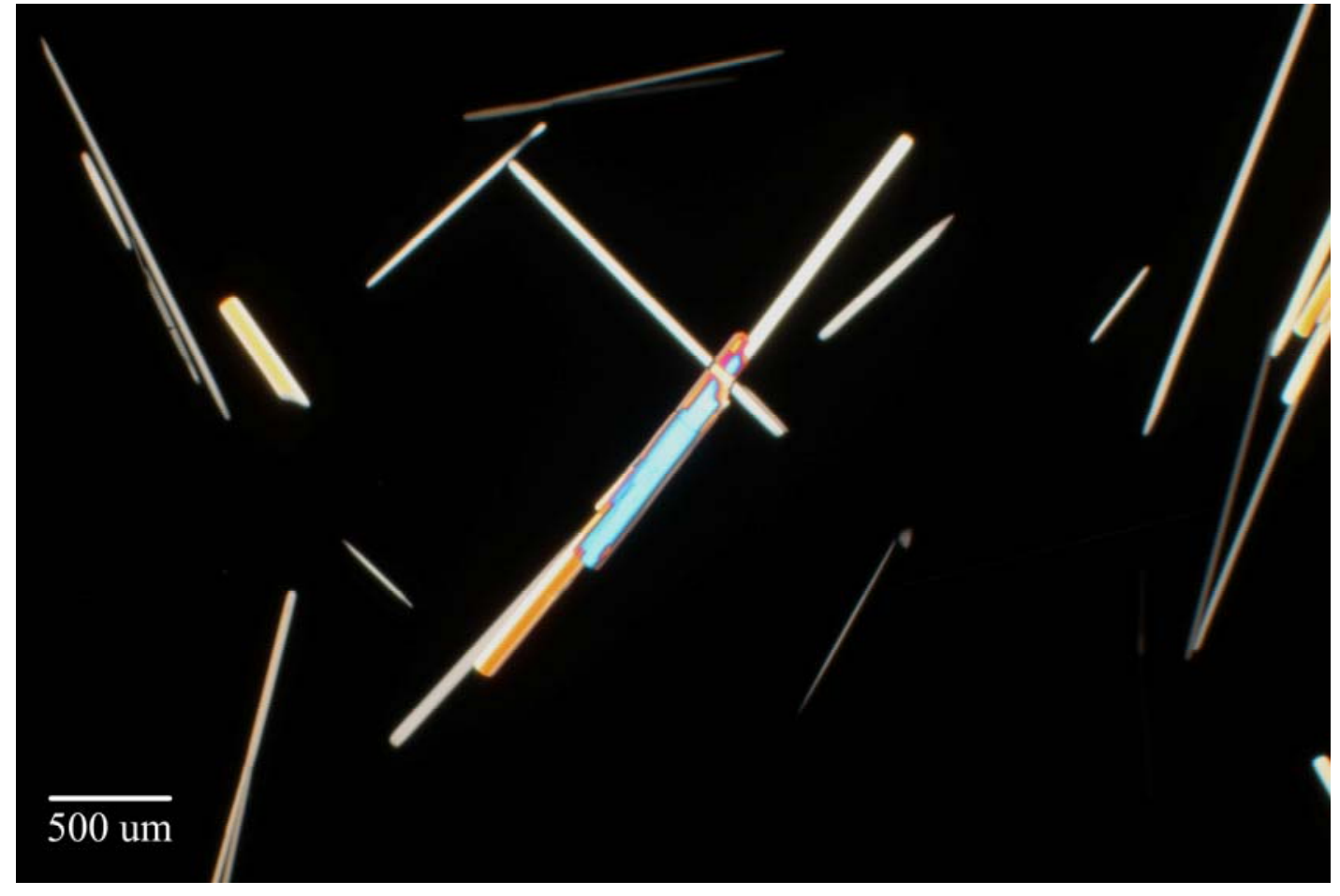

Figure 3.4. Cross-Polarized Light OM of Sodium Phosphate in Sample 2341 (Wash 3) 


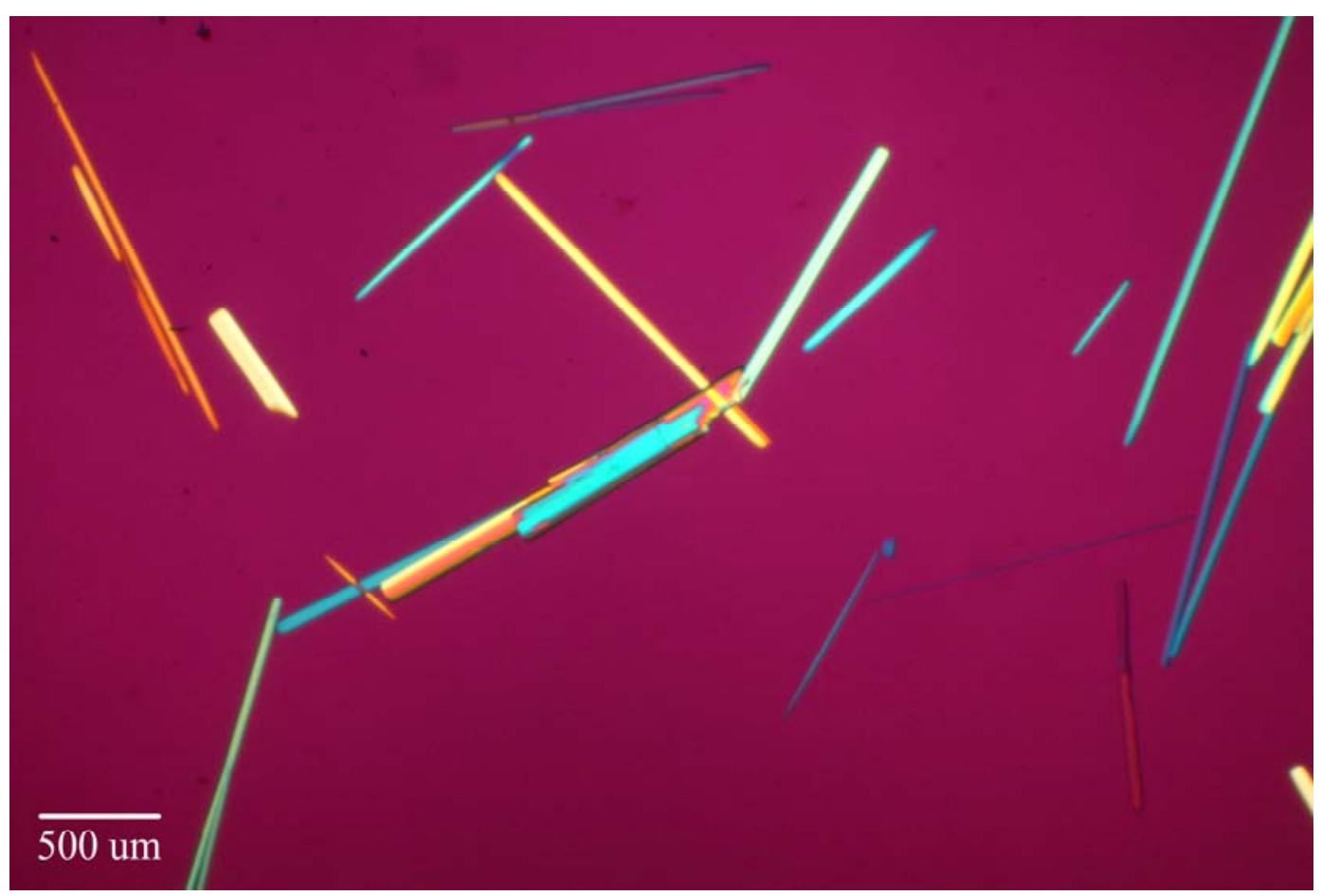

Figure 3.5. Cross-Polarized Light OM of Sodium Phosphate in Sample 2341 (Wash 3) with Full Wave Plate

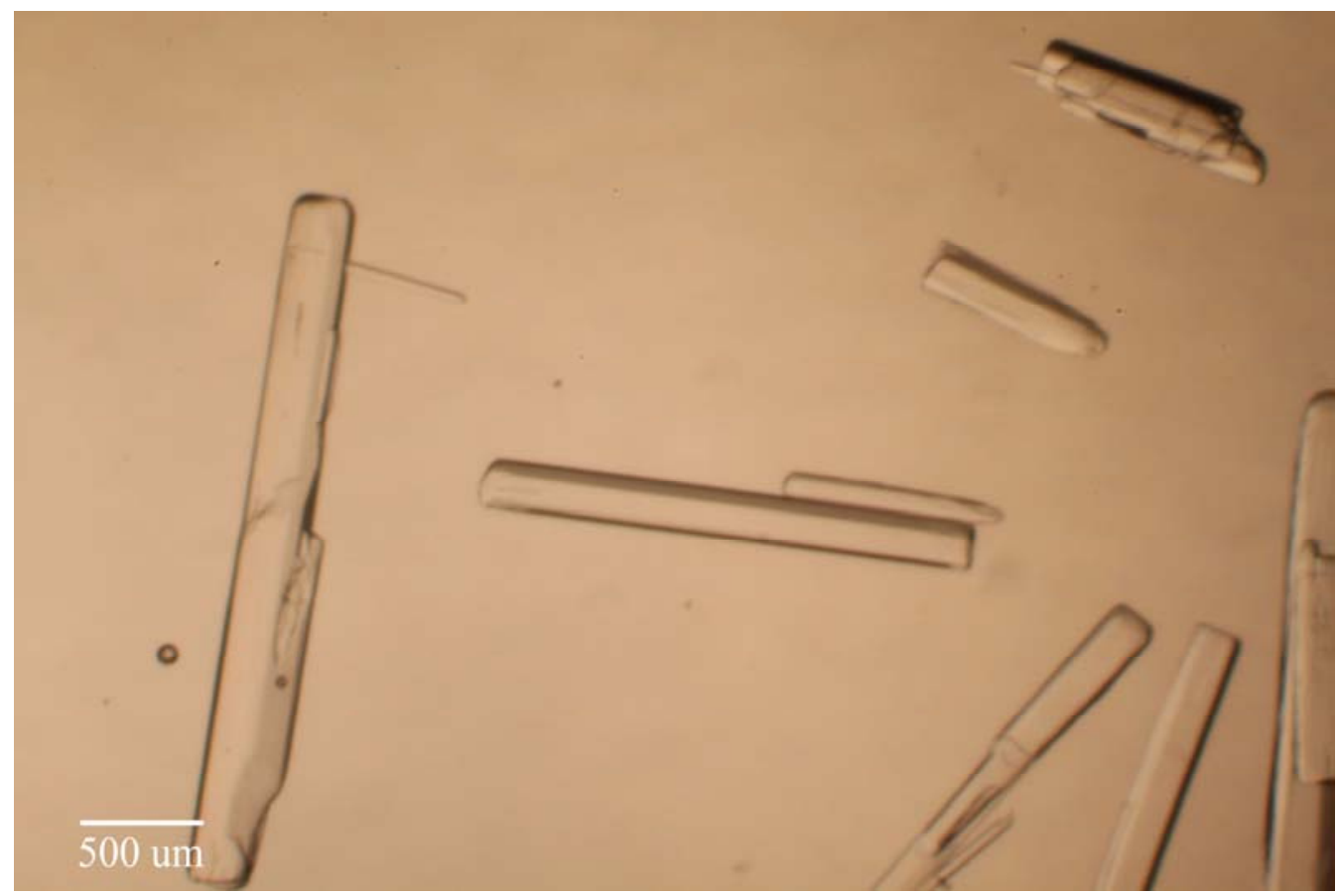

Figure 3.6. Polarized Light OM of Sodium Phosphate in Sample 2349 (Wash 11) 


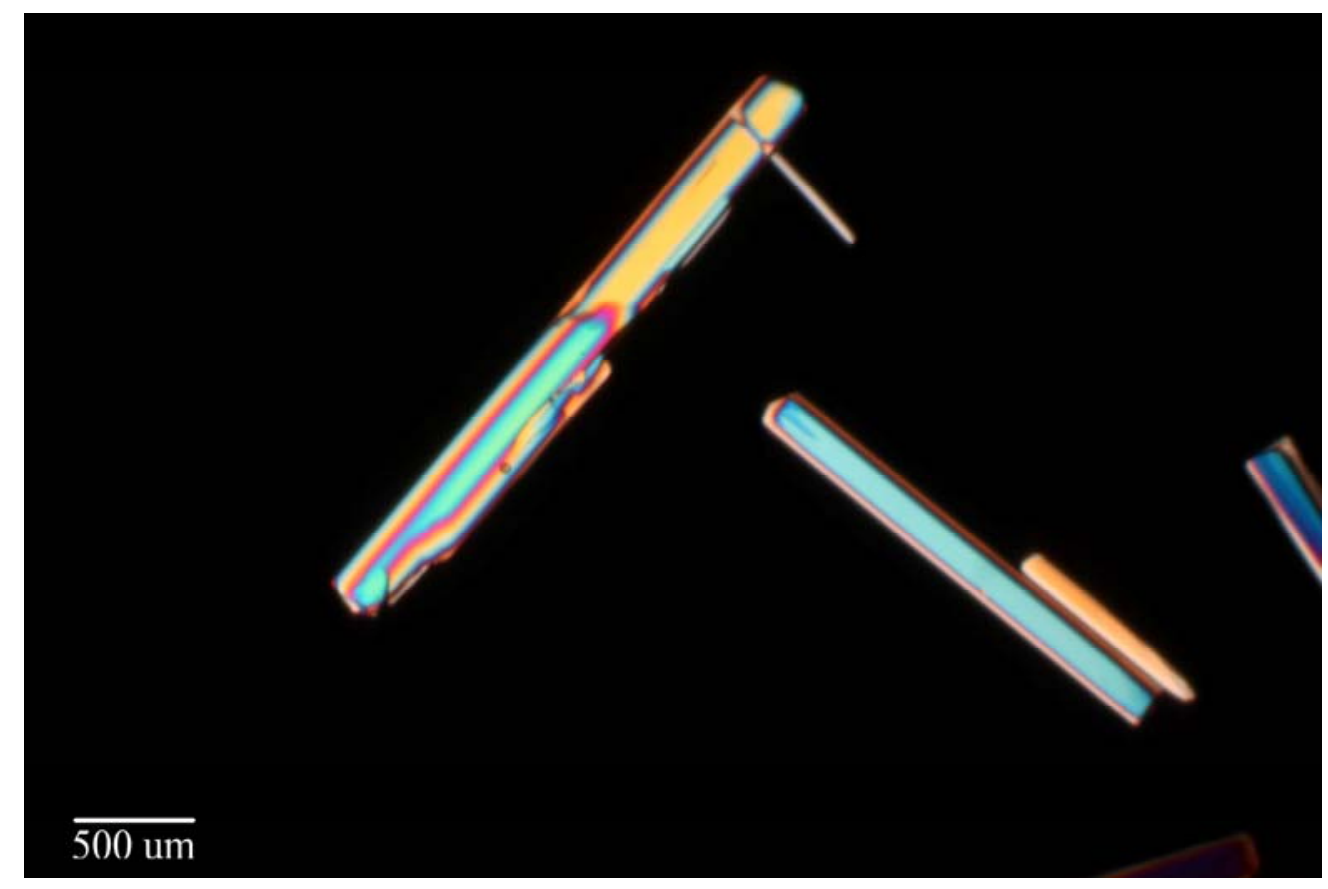

Figure 3.7. Cross-Polarized Light OM of Sodium Phosphate in Sample 2349 (Wash 11)

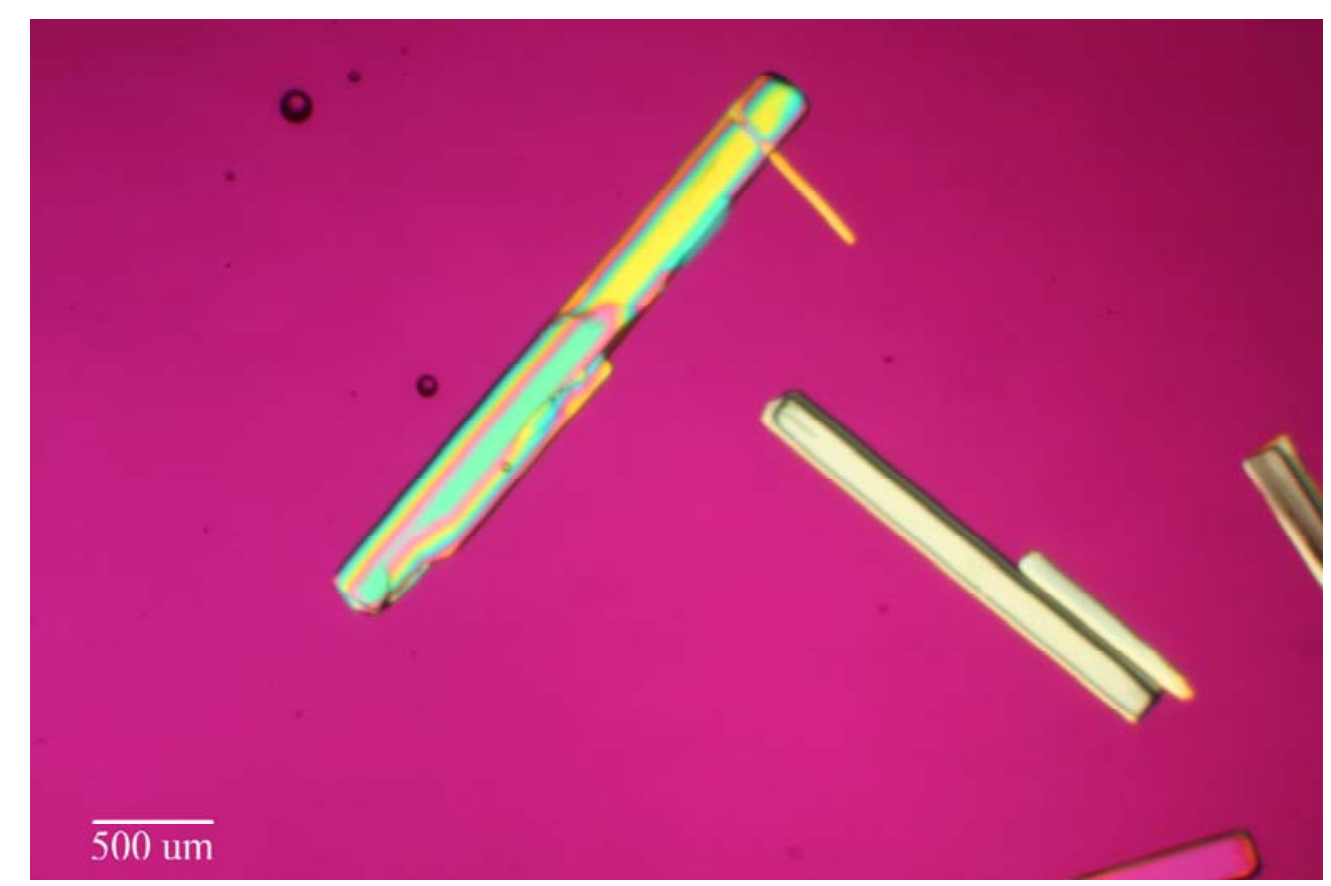

Figure 3.8. Cross-Polarized Light OM of Sodium Phosphate in Sample 2349 (Wash 11) with Full Wave Plate 


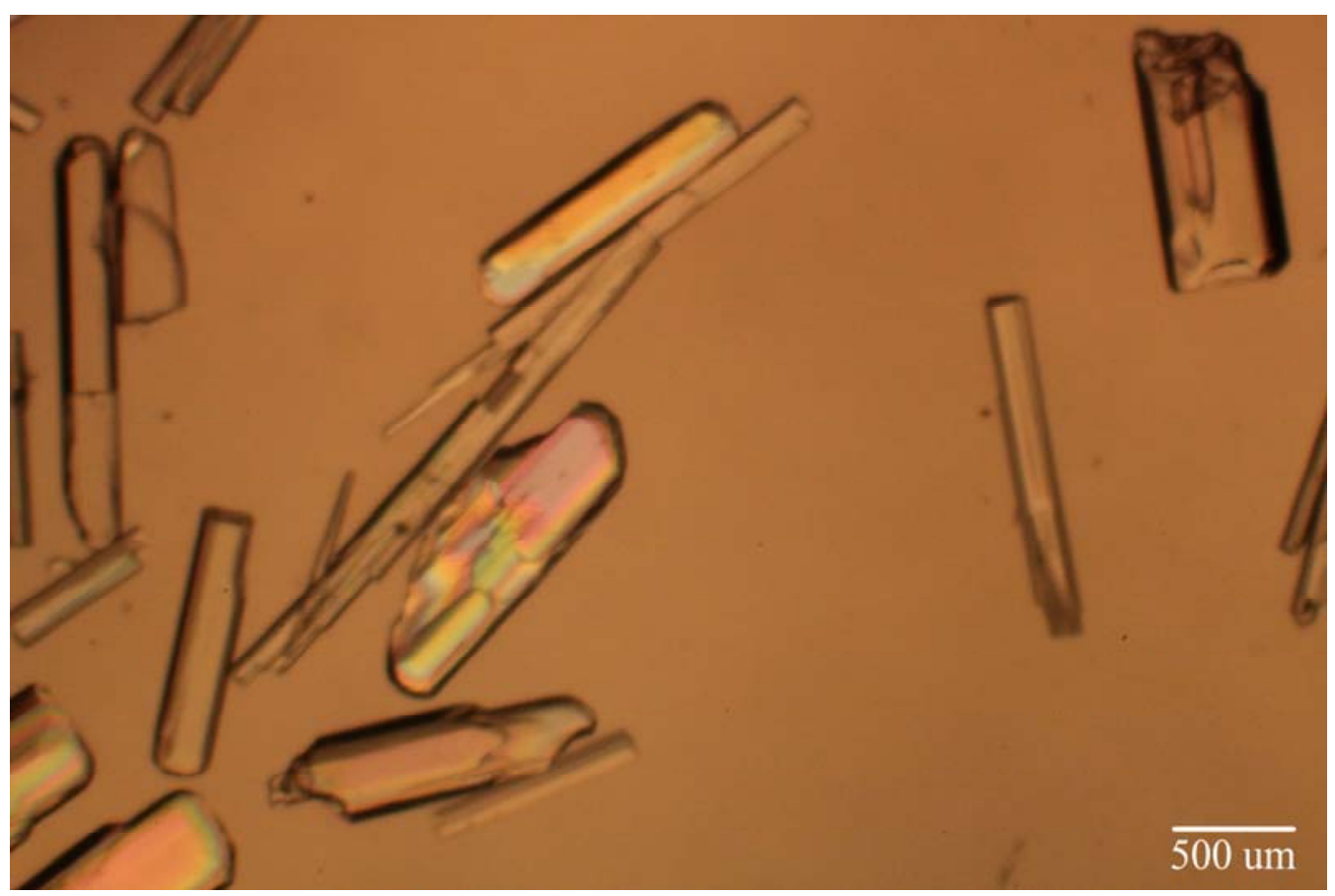

Figure 3.9. Polarized Light OM of Sodium Phosphate in Sample 2363 (Wash 25)

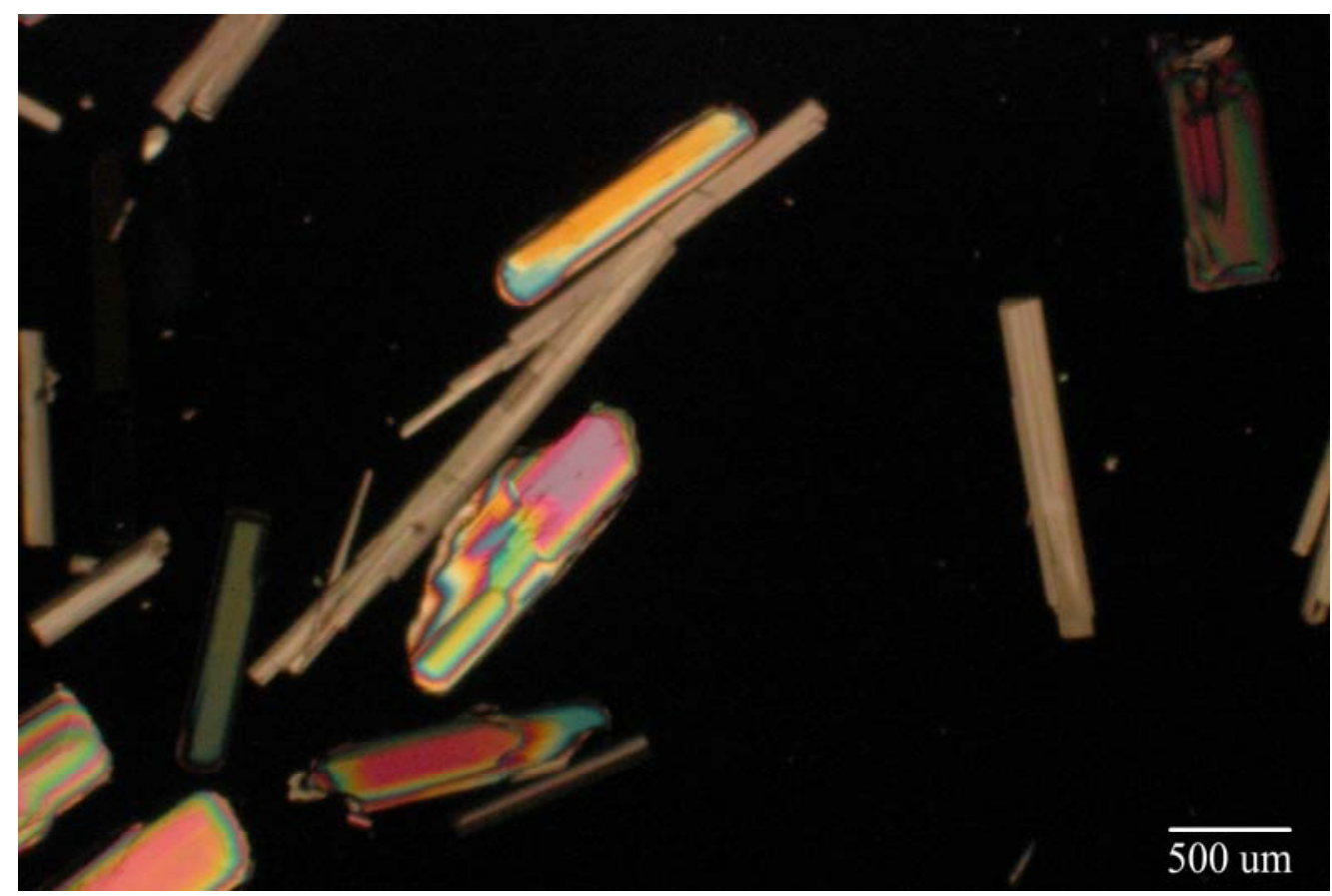

Figure 3.10. Cross-Polarized Light OM of Sodium Phosphate in Sample 2363 (Wash 25) 


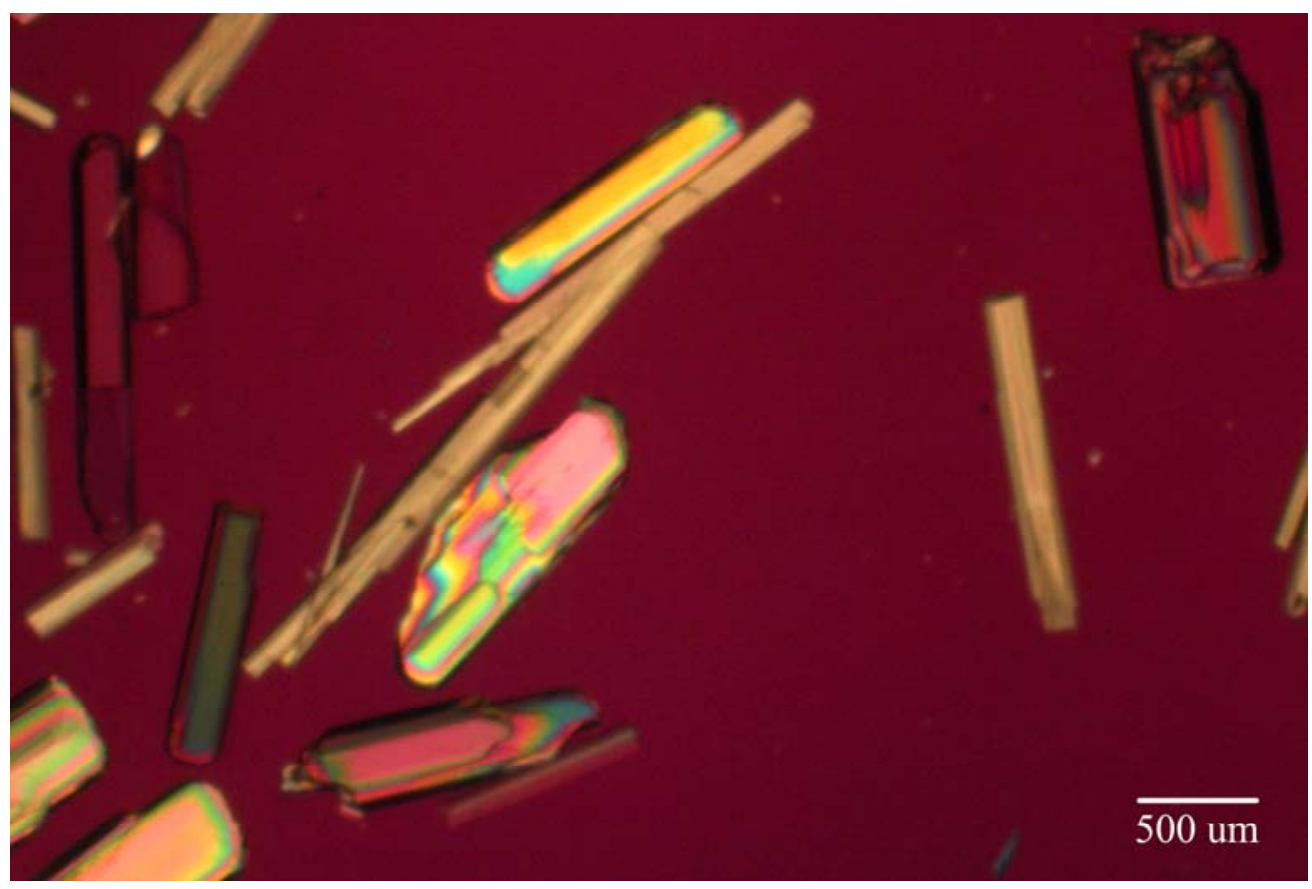

Figure 3.11. Cross-Polarized Light OM of Sodium Phosphate in Sample 2363 (Wash 25) with Full Wave Plate

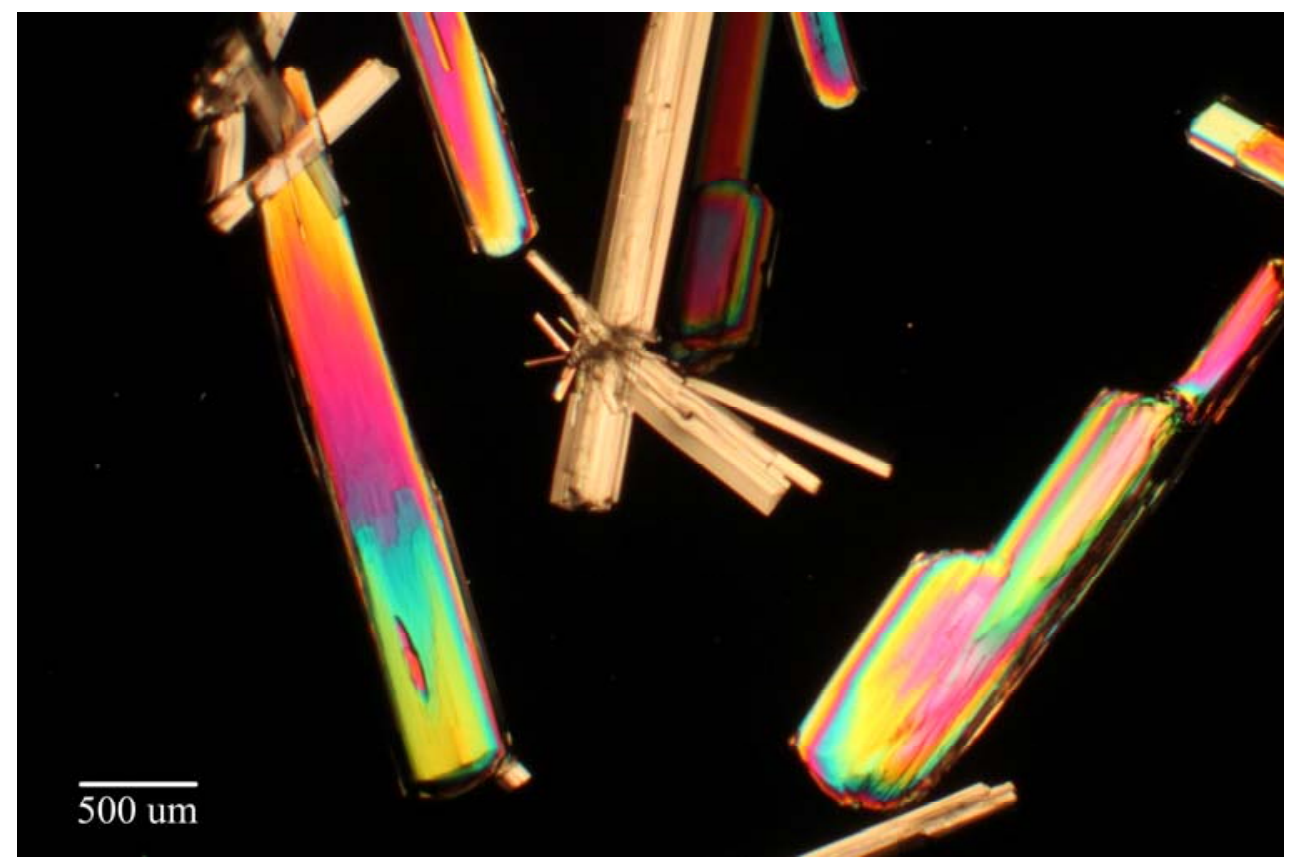

Figure 3.12. Cross-Polarized Light OM of Sodium Oxalate in Sample 2369 (Wash 31) 
Particle size analysis was performed using I-mage software on polarized light micrographs. The crystals were manually fit using the multiline function to define the crystal perimeter. The software then calculated the crystal area, maximum length, and maximum width. The summary of results is shown in Table 3.5 with the complete results shown in Appendix A, Table A.10 through Table A.13.

Table 3.5. Summary Table of Measured Crystal Dimensions for Each Sample

\begin{tabular}{cccccc}
\hline \multirow{3}{*}{ Sample \# } & \# of particles & Statistical & & Max Length, & Max Width, \\
2341 & Measure & Area, $\mu \mathrm{m}^{2}$ & $\mu \mathrm{m}$ & $\mu \mathrm{m}$ \\
\hline \multirow{3}{*}{18} & Mean & 47,440 & 994 & 53.6 \\
& & Min & 2,288 & 102 & 20.6 \\
& & Max & 194,030 & 1,750 & 148 \\
\hline \multirow{3}{*}{2349} & \multirow{2}{*}{20} & Mean & 536,183 & 2,040 & 301 \\
& & Min & 80,973 & 673 & 71 \\
& & Max & $2,206,430$ & 4,200 & 656 \\
\hline \multirow{3}{*}{2363} & 12 & Mean & 297,616 & 1,350 & 272 \\
& & Min & 93,673 & 668 & 143 \\
& & Max & 543,611 & 2,470 & 537 \\
\hline \multirow{3}{*}{2369} & \multirow{3}{*}{21} & Mean & 126,568 & 951 & 144 \\
& & Min & 1,157 & 83 & 30 \\
\hline & & Max & 425,482 & 2,030 & 426 \\
\hline
\end{tabular}

The solids in sample 2341 (wash 3) were identified as primarily sodium hydrogen phosphate when analyzed by XRD as shown in Figure 3.13. Samples 2349 (wash 11) in Figure 3.14 and 2363 (wash 25) in Figure 3.15 were also identified as sodium hydrogen phosphate dihydrate by XRD. These results are all in agreement with the chemical analysis and PLM for these samples indicating that the precipitates are phosphates, but they disagree on the form of phosphate. It appears that the sodium phosphate may have disproportionated to sodium hydrogen phosphate and sodium hydroxide upon drying. However, this was not confirmed. The XRD identified sample 2369 (wash 31) to be sodium oxalate, as seen in Figure 3.16. This result is in agreement with the chemical analysis and PLM for this sample. 


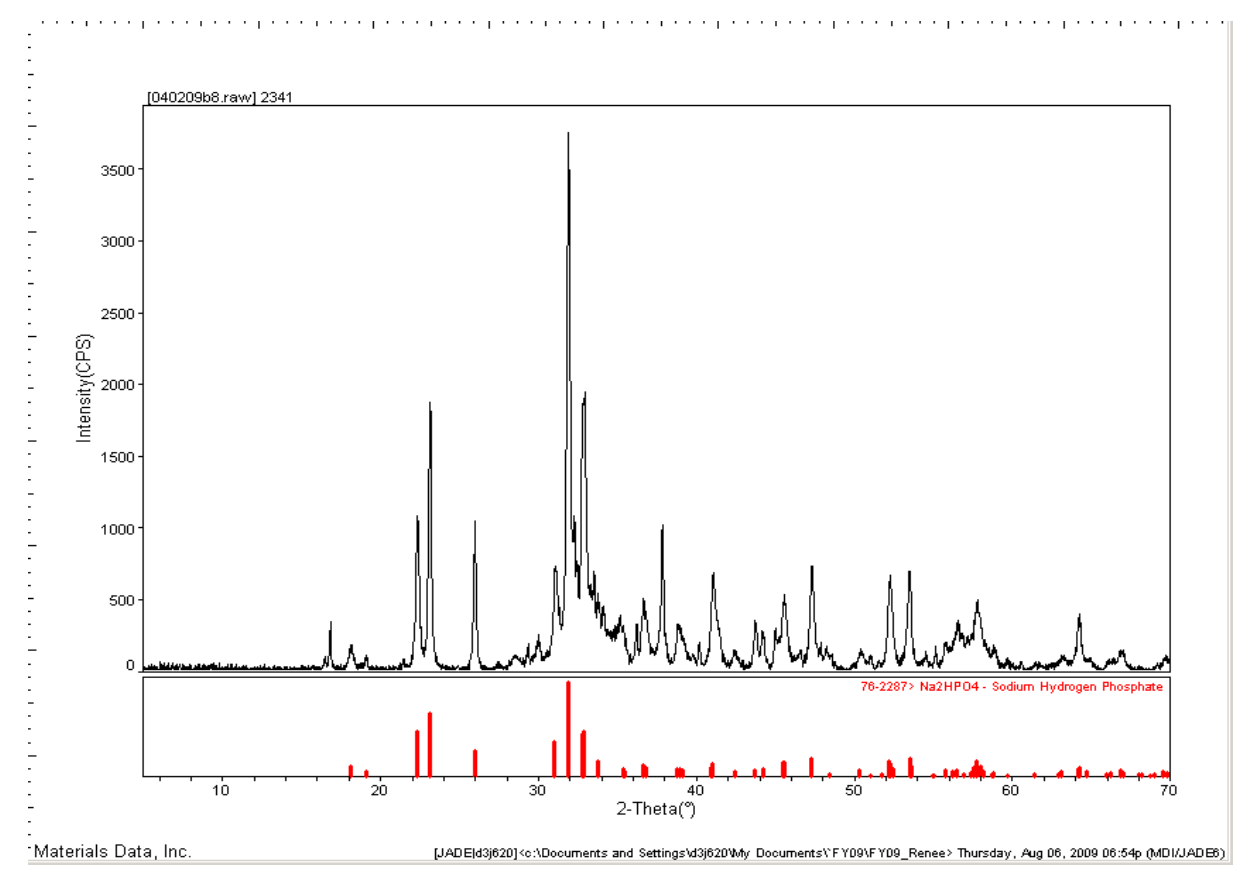

Figure 3.13. XRD Pattern of Crystals from Integrated Test A Wash 3 (Sample Bottle 2341) Identified to be Sodium Hydrogen Phosphate $\left(\mathrm{Na}_{2} \mathrm{HPO}_{4}\right)$

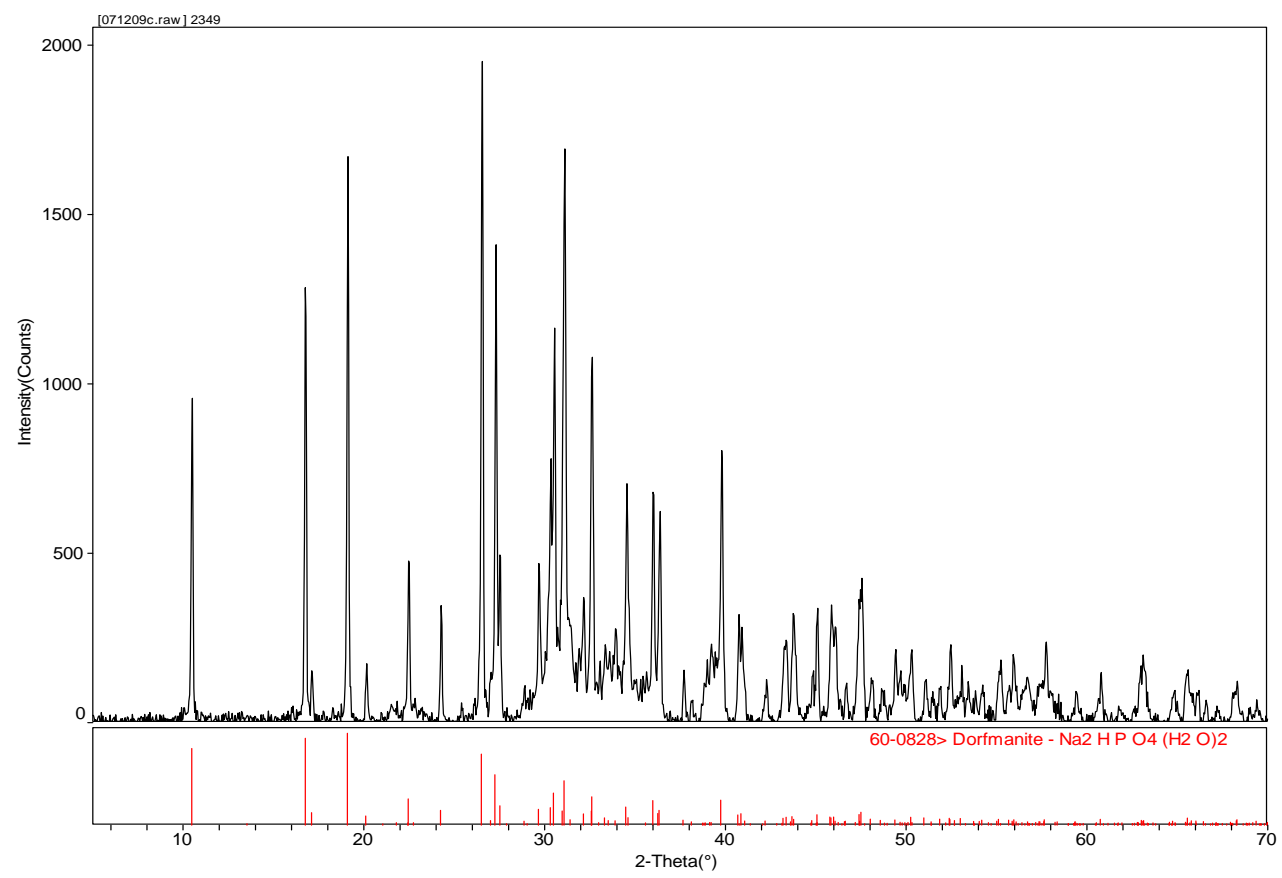

Figure 3.14. XRD Pattern of Crystals from Integrated Test A Wash 11 (Sample Bottle 2349) Identified to be Sodium Hydrogen Phosphate $\left(\mathrm{Na}_{2} \mathrm{HPO}_{4}-2 \mathrm{H}_{2} \mathrm{O}\right)$ 


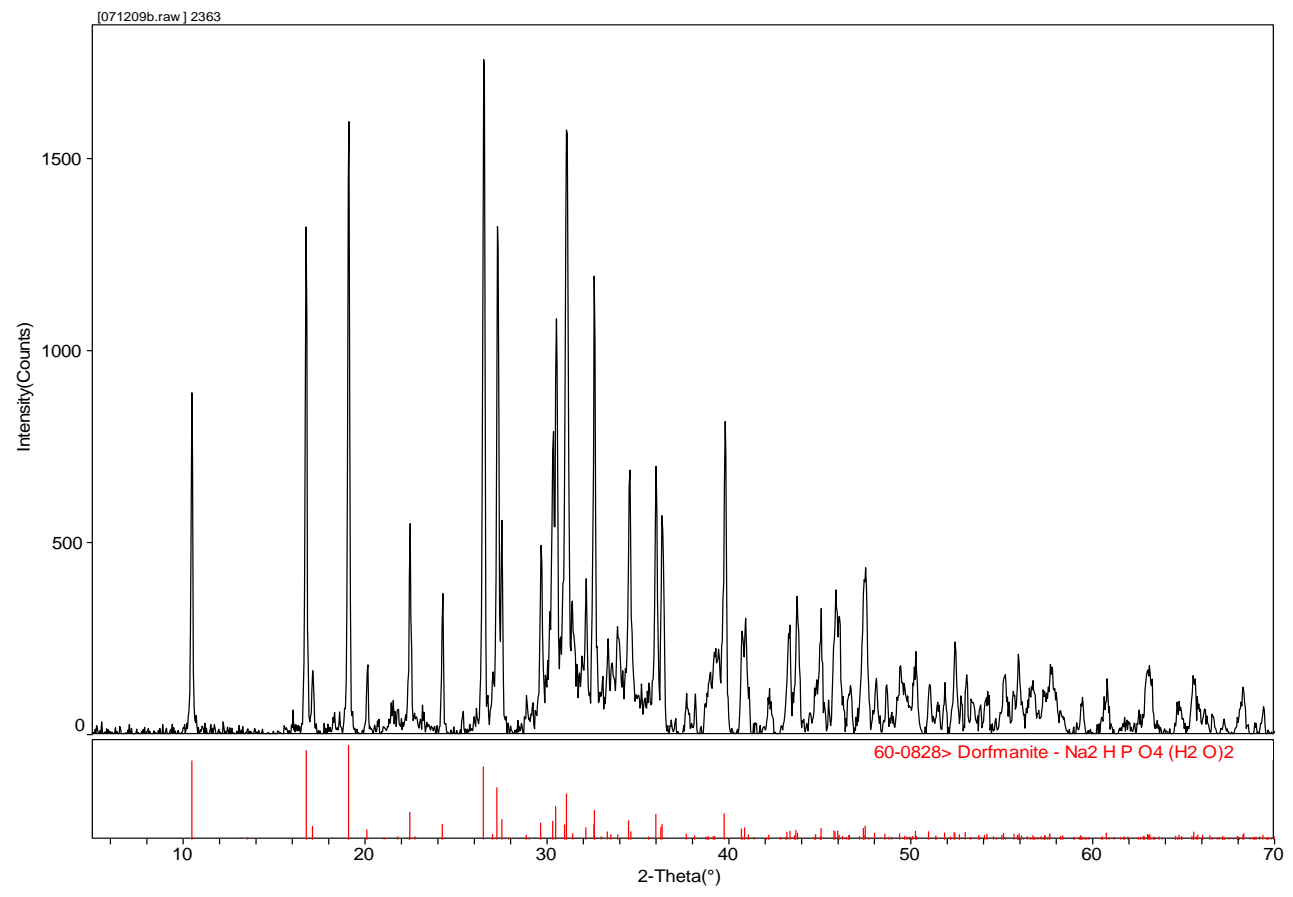

Figure 3.15. XRD Pattern of Crystals from Integrated Test A Wash 25 (Sample Bottle 2363) Identified to be Sodium Hydrogen Phosphate $\left(\mathrm{Na}_{2} \mathrm{HPO}_{4}-2 \mathrm{H}_{2} \mathrm{O}\right)$

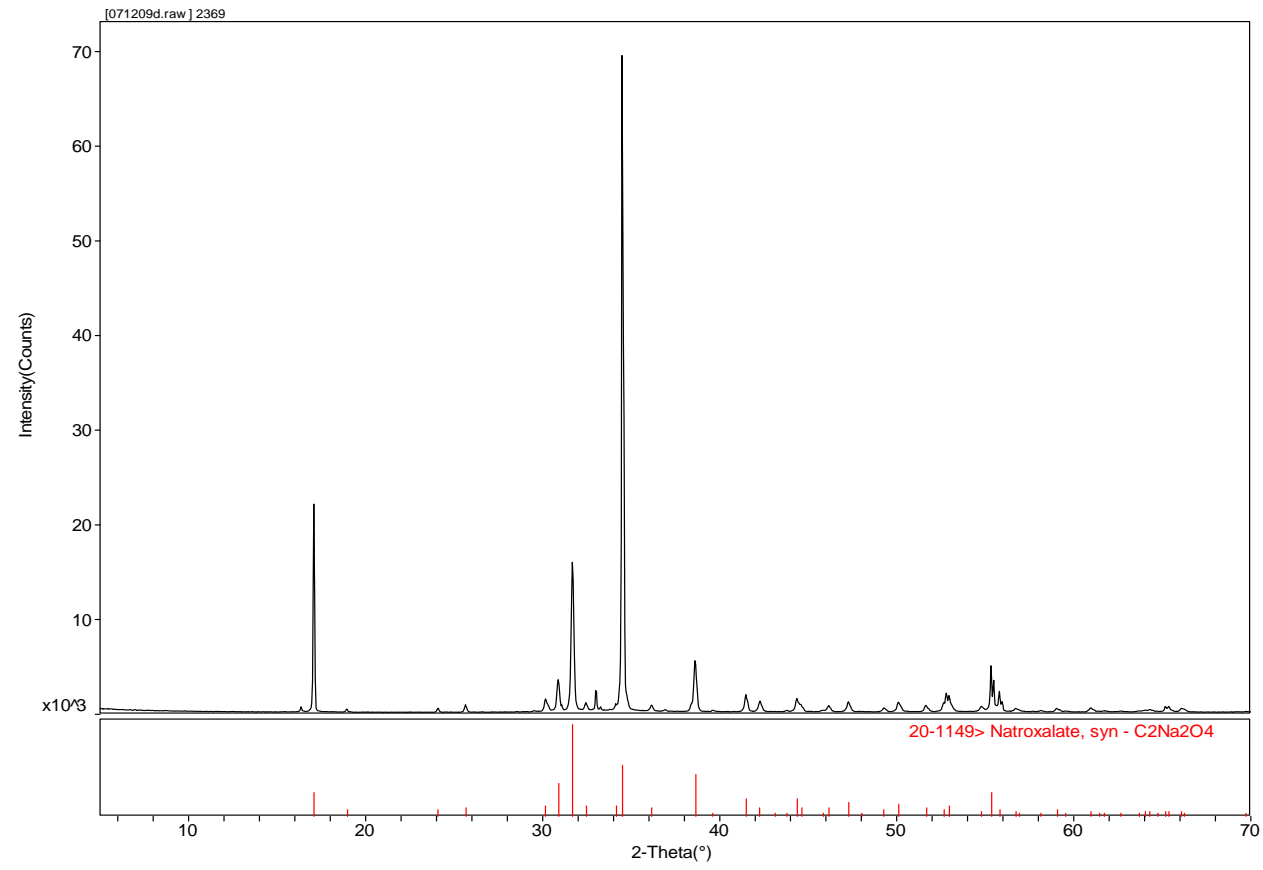

Figure 3.16. XRD Pattern of Crystals from Integrated Test A Wash 31 (Sample Bottle 2369) Identified to be Sodium Oxalate $\left(\mathrm{Na}_{2} \mathrm{C}_{2} \mathrm{O}_{4}\right)$ 
For samples 2341 (wash 3), 2349 (wash 11), 2363 (wash 25), and 2369 (wash 31), a portion of the filtered and air-dried solids were dissolved in deionized water (DIW) in a ratio of approximately 40:1 and analyzed by ICP (Table 3.6) and IC (Table 3.7). These results confirmed what the PLM and XRD showed, namely that samples 2341,2349 , and 2363 were sodium phosphate whereas sample 2369 was sodium oxalate. This can be explained by 1) differences in the solubilities of sodium phosphate and sodium oxalate as a function of sodium ion concentrations in solution, and 2) the quantities of precipitated phosphates and oxalates at the end of the caustic leaching operation. Aluminum compounds were not observed to precipitate in these washes.

Analysis of the data presented in Table 3.7 indicates that the phosphate contains approximately six waters of hydration, while the oxalate contains no apparent waters of hydration. Also note that these samples contained very little soluble salts after drying. The ratio of $\mathrm{Na}$ to $\mathrm{P}$ of $3.5: 1$ suggests that only about $14 \%$ ( 0.5 of 3.5$)$ of the salt present in the solids after drying is from soluble salts (or bound sodium hydroxide).

Table 3.6. ICP Results for Integrated Test A Post-Caustic-Precipitate Composition Dissolved in DIW

\begin{tabular}{cccccccc}
\hline Sample ID & Wash \# & $\begin{array}{c}\text { Solids Wt } \\
(\mathrm{g})\end{array}$ & $\begin{array}{c}\text { DIW Wt } \\
(\mathrm{g})\end{array}$ & $\begin{array}{c}\mathrm{Al} \\
(\mu \mathrm{g} / \mathrm{mL})\end{array}$ & $\begin{array}{c}\mathrm{Na} \\
(\mu \mathrm{g} / \mathrm{mL})\end{array}$ & $\begin{array}{c}\mathrm{P} \\
(\mu \mathrm{g} / \mathrm{mL})\end{array}$ & $\begin{array}{c}\mathrm{S} \\
(\mu \mathrm{g} / \mathrm{mL})\end{array}$ \\
\hline 2341 & 3 & 0.5147 & 20.3946 & 39.1 & 7,240 & 2,590 & 77 \\
2349 & 11 & 0.5037 & 20.4030 & 23.0 & 6,990 & 2,600 & 34 \\
2363 & 25 & 0.4975 & 20.2410 & 9.54 & 6,980 & 2,700 & $<2.45$ \\
2369 & 31 & 0.1725 & 8.4439 & 11.2 & 7,030 & $<1.75$ & $<2.45$ \\
\hline
\end{tabular}

Table 3.7. IC Results for Integrated Test A Post-Caustic-Precipitate Composition Dissolved in DIW

\begin{tabular}{ccccccccc}
\hline $\begin{array}{c}\text { Sample } \\
\mathrm{ID}\end{array}$ & $\begin{array}{c}\text { Wash } \\
\#\end{array}$ & $\begin{array}{c}\text { Solids Wt } \\
(\mathrm{g})\end{array}$ & $\begin{array}{c}\mathrm{DIW} \text { Wt } \\
(\mathrm{g})\end{array}$ & $\begin{array}{c}\mathrm{C}_{2} \mathrm{O}_{4} \\
(\mu \mathrm{g} / \mathrm{mL})\end{array}$ & $\begin{array}{c}\mathrm{PO}_{4} \\
(\mu \mathrm{g} / \mathrm{mL})\end{array}$ & $\begin{array}{c}\mathrm{SO}_{4} \\
(\mu \mathrm{g} / \mathrm{mL})\end{array}$ & $\begin{array}{c}\mathrm{NO}_{3} \\
(\mu \mathrm{g} / \mathrm{mL})\end{array}$ & $\begin{array}{c}\mathrm{NO}_{2} \\
(\mu \mathrm{g} / \mathrm{mL})\end{array}$ \\
\hline 2341 & 3 & 0.5147 & 20.3946 & $<23$ & 8,250 & 63 & 260 & 32 \\
2349 & 11 & 0.5037 & 20.4030 & $<23$ & 8,350 & 36 & 170 & 23 \\
2363 & 25 & 0.4975 & 20.2410 & 26 & 8,700 & $<34$ & 82 & $<23$ \\
2369 & 31 & 0.1725 & 8.4439 & 13,400 & 45 & $<34$ & 58 & $<23$ \\
\hline
\end{tabular}





\subsection{Determination of Rate of Approach to Equilibrium Concentrations}

The objective of these tests was to determine the rate at which the anions of interest (phosphate, oxalate, sulfate, silicate, and fluoride) approach equilibrium solution composition in post-caustic-leach slurry at $25^{\circ} \mathrm{C}$ before filtration using controlled laboratory experiments. These tests were specified in Test Exception WTP-TEF-RT-09-0001, Rev 1, Task 2 associated with Test Plan TP-WTP-PEP-044, Rev 0.2 .

These tests were performed using simplified post-caustic-leach slurry simulant (derived from the PEP Integrated Test A) with the composition shown in Table 4.1. This simulant contained filtration sludge and a supernate containing sufficient aluminate to represent dissolved gibbsite/boehmite, nitrate, nitrite, carbonate, and hydroxide only. The other anions were deleted from the simulant composition so that they could be spiked and the concentration controlled. The post-caustic-leach slurry simulant was spiked with each anion of interest (phosphate, oxalate, sulfate, silicate, and fluoride) in the form of a sodium salt as shown in Table 4.2.

Table 4.1. Simplified Post-Caustic-Leach Slurry Simulant Composition

\begin{tabular}{lc}
\hline \multicolumn{1}{c}{ Chemical } & Amount $(\mathrm{g} / \mathrm{kg})$ \\
\hline Fe-rich slurry & 40.0 \\
$\mathrm{NaNO}_{3}$ & 75.3 \\
$\mathrm{NaNO}_{2}$ & 18.5 \\
$\mathrm{NaOH}$ & 149.6 \\
$\mathrm{NaAl}(\mathrm{OH})_{4}$ & 36.9 \\
$\mathrm{Na}_{2} \mathrm{CO}_{3}$ & 7.42 \\
$\mathrm{DIW}$ & 677.2 \\
\hline
\end{tabular}

Table 4.2. Test Matrix Identification for Task 2

\begin{tabular}{ccccccc}
\hline Test ID & $\begin{array}{c}\text { Post-Caustic- } \\
\text { Leach Slurry } \\
(\mathrm{g})\end{array}$ & $\begin{array}{c}\mathrm{Na}_{2} \mathrm{C}_{2} \mathrm{O}_{4^{-}} \\
\mathrm{H}_{2} \mathrm{O} \\
(\mathrm{g})\end{array}$ & $\begin{array}{c}\mathrm{Na}_{3} \mathrm{PO}_{4^{-}} \\
12 \mathrm{H}_{2} \mathrm{O} \\
(\mathrm{g})\end{array}$ & $\begin{array}{c}\mathrm{Na}_{2} \mathrm{SO}_{4} \\
(\mathrm{~g})\end{array}$ & $\begin{array}{c}\mathrm{NaF} \\
(\mathrm{g})\end{array}$ & $\begin{array}{c}\mathrm{Na}_{2} \mathrm{SiO}_{3^{-}} \\
9 \mathrm{H}_{2} \mathrm{O} \\
(\mathrm{g})\end{array}$ \\
\hline T2-1a & 1000.06 & 80.88 & 52.63 & 14.75 & 13.59 & 14.33 \\
$\mathrm{~T} 2-1 \mathrm{~b}$ & 1000.03 & 80.88 & 52.63 & 14.75 & 13.59 & 14.33 \\
$\mathrm{~T} 2-1 \mathrm{c}$ & 1000.06 & 80.88 & 52.63 & 14.75 & 13.59 & 14.33 \\
$\mathrm{~T} 2-2$ & 1000.07 & 80.88 & 52.63 & 14.75 & 0.00 & 0.00 \\
$\mathrm{~T} 2-3$ & 1000.03 & 0.00 & 52.63 & 0.00 & 13.59 & 14.33 \\
$\mathrm{~T} 2-4$ & 1000.05 & 0.00 & 52.63 & 0.00 & 0.00 & 0.00 \\
$\mathrm{~T} 2-5$ & 1000.08 & 0.00 & 52.63 & 14.75 & 13.59 & 14.33 \\
$\mathrm{~T} 2-6$ & 1000.01 & 0.00 & 0.00 & 14.75 & 0.00 & 0.00 \\
$\mathrm{~T} 2-7$ & 1000.07 & 80.88 & 0.00 & 0.00 & 13.59 & 14.33 \\
$\mathrm{~T} 2-8$ & 1000.03 & 80.88 & 0.00 & 0.00 & 0.00 & 0.00 \\
$\mathrm{~T} 2-9$ & 1000.05 & 0.00 & 0.00 & 0.00 & 0.00 & 0.00 \\
\hline
\end{tabular}


The slurries in the test matrix above were processed as follows:

- Heated to $85^{\circ} \mathrm{C}$ for 25.5 hours, shaken once an hour for the first 12 hours, and allowed to sit for the remaining 13.5 hours.

- Sampled for IC and ICP (T2-1a- $85^{\circ} \mathrm{C}$ to T2-9 $\left.-85^{\circ} \mathrm{C}\right)$. See Appendix A for data summary.

- Cooled with shaking to $25 \pm 1^{\circ} \mathrm{C}$ over 5.5 hours. This cooling period corresponds to the estimated cooling time in Integrated Test A.

- Held at $25 \pm 1^{\circ} \mathrm{C}$ with shaking for 24 hours and sampled at $0,1,2,4,8,12$, and 24 hours for IC and $\mathrm{ICP}\left(\mathrm{T} 2-1 \mathrm{a}-25^{\circ} \mathrm{C}-0\right.$ to $\left.\mathrm{T} 2-9-25^{\circ} \mathrm{C}-24\right)$.

- Cooled with shaking to $16 \pm 1^{\circ} \mathrm{C}$ over 4.3 hours and held at $16 \pm 1^{\circ} \mathrm{C}$ for 20 hours.

- Sampled for IC and ICP after the 20 hours (T2-1a- $15^{\circ} \mathrm{C}$ to $\left.\mathrm{T} 2-9-15^{\circ} \mathrm{C}\right)$.

- Heated with shaking to $25^{\circ} \mathrm{C}$ over 3.5 hours.

- Held at $25 \pm 1{ }^{\circ} \mathrm{C}$ with shaking for 96 hours and sampled at 24 and 96 hours for IC and ICP (T2-1a-25 ${ }^{\circ} \mathrm{C}-\mathrm{b}-24$ to $\left.\mathrm{T} 2-9-25^{\circ} \mathrm{C}-\mathrm{b}-96\right)$.

The 11 test bottles were placed in an oven at $85^{\circ} \mathrm{C}$ for 25.5 hours, shaken manually once an hour for the first 12 hours to mix them well, and then allowed to sit for the remaining 13.5 hours. After 25.5 hours at $85^{\circ} \mathrm{C}$, the test bottles were removed from the oven and sampled by placing approximately $1.5-\mathrm{mL}$ of supernate (filtered through a $0.45-\mu \mathrm{m}$ filter immediately) into a sample bottle containing approximately $15-\mathrm{mL}$ of DIW to dilute it approximately 10 times. Then the slurry test bottles were placed into an incubator at a temperature of $71.1^{\circ} \mathrm{C}$ and cooled to $25 \pm 1^{\circ} \mathrm{C}$ over 5.5 hours as shown in Figure 4.1 while shaking at $150 \mathrm{rpm}$. Note that the liquid blank was at $71.1^{\circ} \mathrm{C}$ - but the actual test bottles were at $85^{\circ} \mathrm{C}$ at the beginning - so the liquid blank temperature was slightly low for the first few readings while the test solutions were losing heat, and therefore the curve is flat at the beginning. The liquid blank was used for tracking temperature and was surrounded by the test bottles.

These test bottles were then held at $25 \pm 1{ }^{\circ} \mathrm{C}$ for 24 hours in the incubator while shaking at $150 \mathrm{rpm}$. They were each sampled at $0,1,2,4,8,12$, and 24 hours. After holding for 24 hours at $25 \pm 1^{\circ} \mathrm{C}$, the temperature of the incubator was lowered to $16 \pm 1^{\circ} \mathrm{C}$ over 4.3 hours as shown in Figure 4.2 while continuing to shake at $150 \mathrm{rpm}$. Another sample was taken from each of the test bottles after they had been held at $16 \pm 1^{\circ} \mathrm{C}$ for 20 hours. The temperature of the incubator was then increased to $25 \pm 1^{\circ} \mathrm{C}$ over 3.5 hours and held at temperature for 92.75 hours with samples taken from each of the test bottles at 24 and 96 hours after the temperature had been raised with the shaker remaining at $150 \mathrm{rpm}$. In all cases, samples for analysis were prepared by placing approximately $1.5-\mathrm{mL}$ of supernate (immediately filtered through a $0.45-\mu \mathrm{m}$ filter) into a labeled sample bottle containing approximately $15-\mathrm{mL}$ of DIW to dilute it approximately 10 times. 


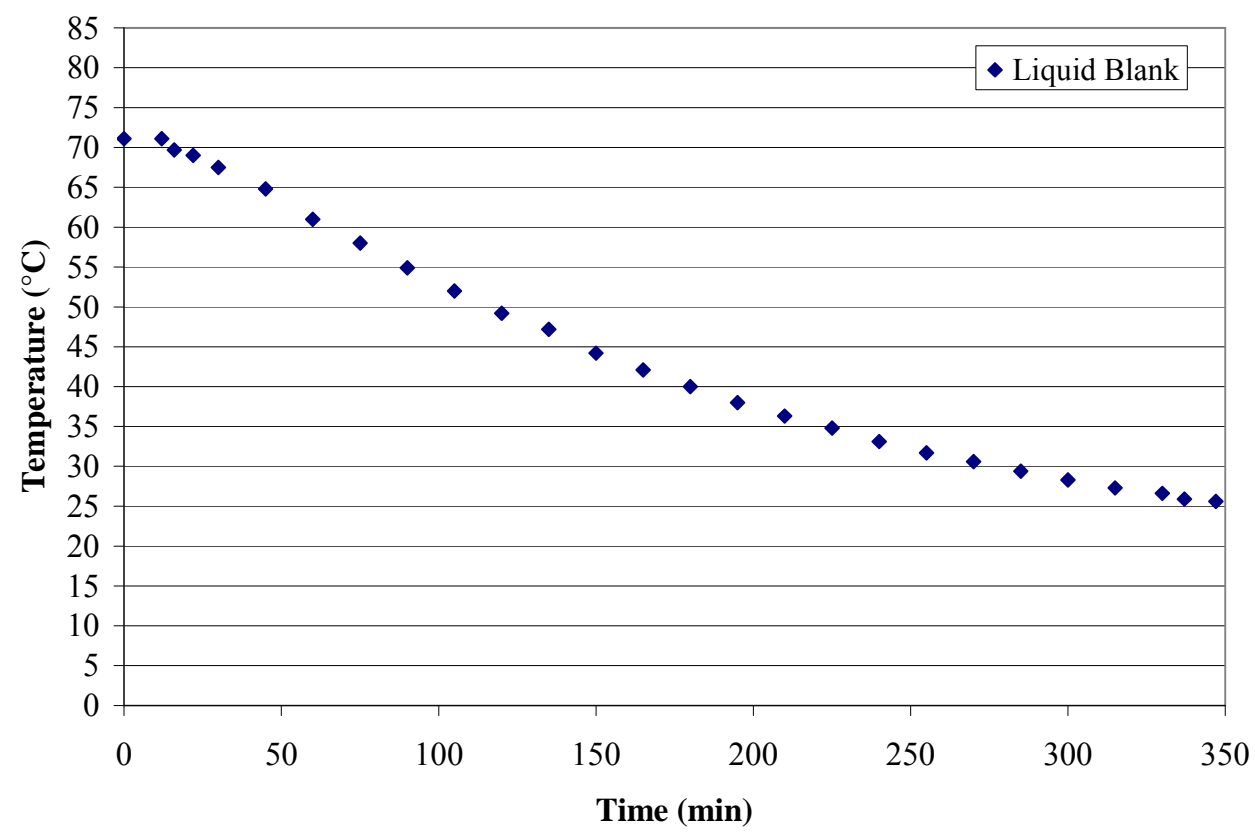

Figure 4.1. Cooling Curve of Test Solutions from $85^{\circ} \mathrm{C}$ to $25^{\circ} \mathrm{C}$

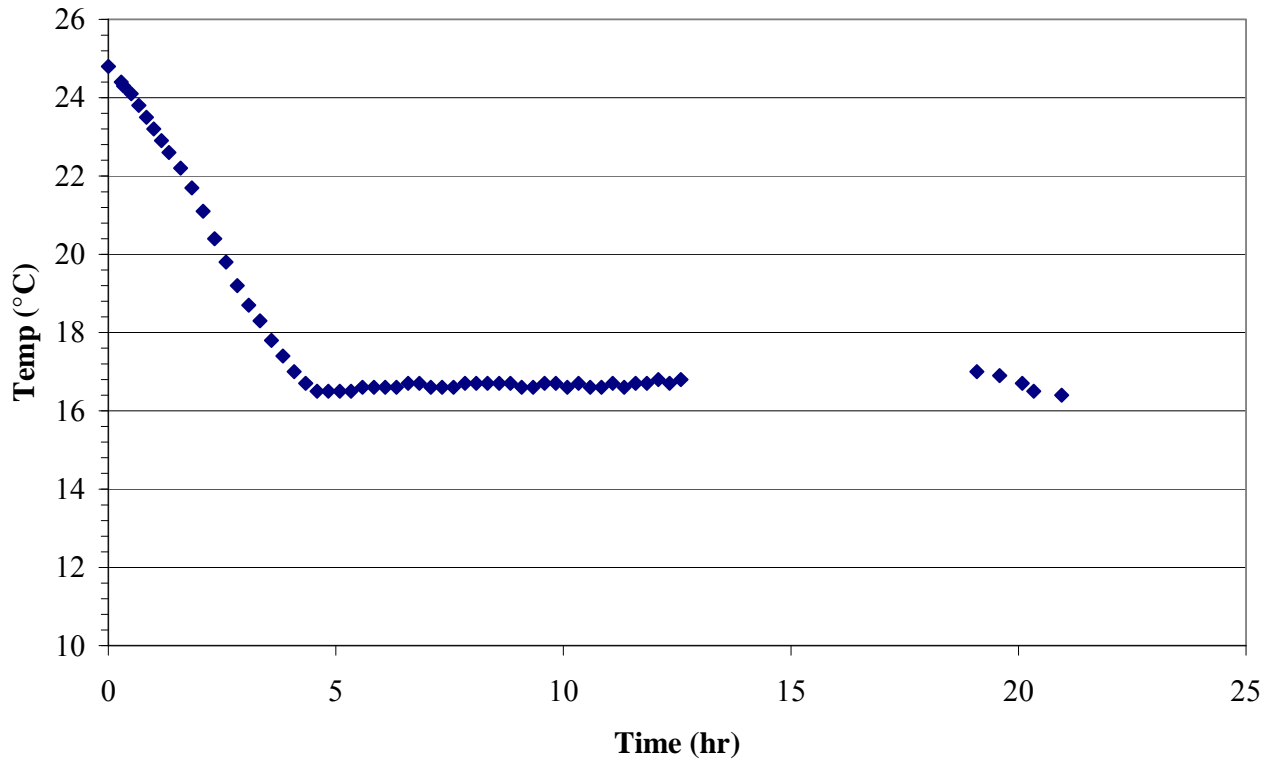

Figure 4.2. Task 2 Cooling Curve from $25^{\circ} \mathrm{C}$ to $16^{\circ} \mathrm{C}$ 
All of the supernate samples taken while the slurry temperature was at $85^{\circ} \mathrm{C}$ for 24 hours developed an orange-brown precipitate after being diluted with DIW and allowed to sit at ambient temperature $(\sim 18$ to $22^{\circ} \mathrm{C}$ ) for 26 hours. Figure 4.3 shows three of the samples. The Fe-rich slurry from Table 4.1 is believed to be the source of the brown precipitate since sample T2-9 (without any anion spikes and shown on the far left in Figure 4.3) had just as much precipitate as the other samples. Chemical analysis confirmed that it was an iron compound. Iron was present in the post-caustic-leach slurry component.

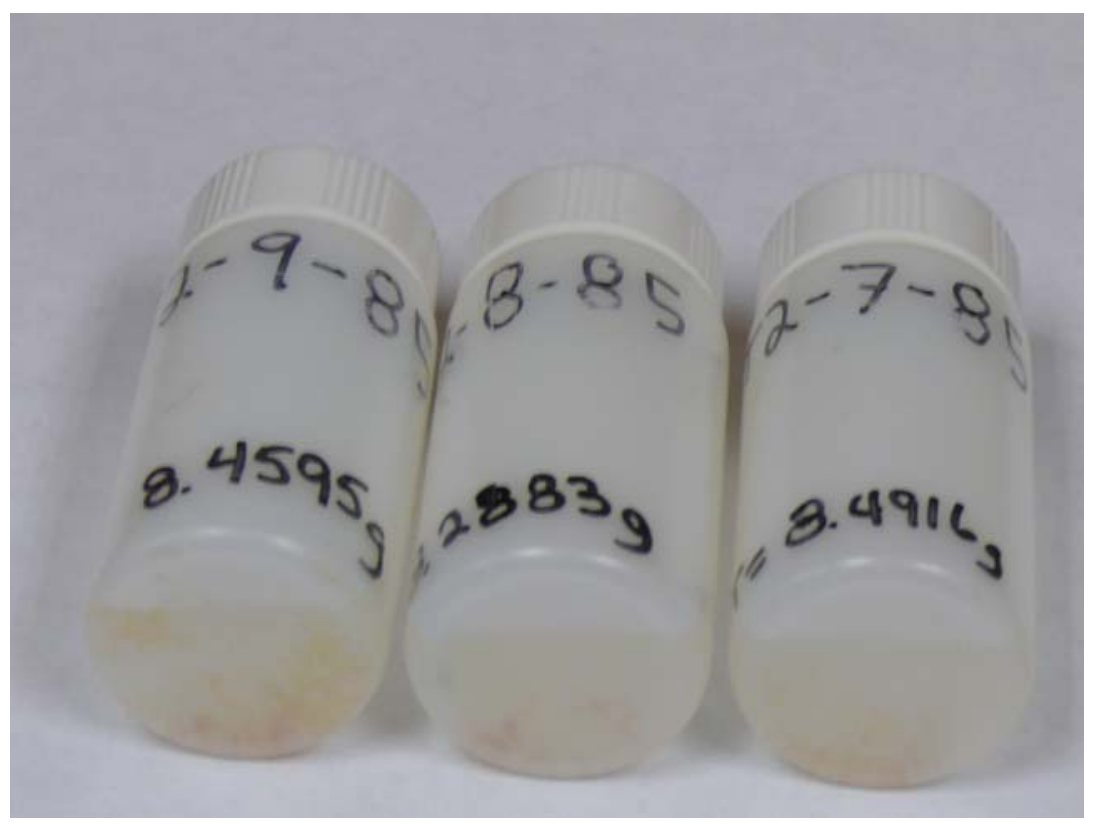

Figure 4.3. Precipitate in $85^{\circ} \mathrm{C}$ Samples from Tests T2-7, T2-8, and T2-9 (from right to left) after 24 Hours at Ambient Temperature $\left(\sim 18\right.$ to $\left.22^{\circ} \mathrm{C}\right)$

Each sample was analyzed by ICP for Al, Na, K, P, S, Si, and Fe and by IC for oxalate, phosphate, sulfate, fluoride, nitrate, and nitrite as shown in Tables A.1 and A.2, respectively. The ICP results showed very low levels of silicon present and no evidence of alumino-silicate precipitation.

Figure 4.4 shows the precipitation of oxalate in the samples by the decrease in oxalate concentration. Oxalate appears to be fairly slow to precipitate, taking nearly 24 hours before reaching equilibrium. The presence of phosphate, sulfate, or fluoride did not significantly change the equilibrium concentration of oxalate, but the kinetics appeared to be slower in the presence of the other anions. The average oxalate concentration is $137-\mathrm{mg} / \mathrm{kg}$ after approximately 48 hours. Note that the initial concentration in the full matrix at $25^{\circ} \mathrm{C}$ is significantly higher, up to $200-\mathrm{mg} / \mathrm{kg}$. The concentration of oxalate at $85^{\circ} \mathrm{C}$ was approximately $450-\mathrm{mg} / \mathrm{kg}$. Results discussed in Section 5 show that oxalate solubility is relatively insensitive to temperature. The solubility at $35^{\circ} \mathrm{C}$ in this matrix is approximately $160-\mathrm{mg} / \mathrm{kg}$ (see Section 5). Thus, this initial supersaturation is significantly in excess of $10^{\circ} \mathrm{C}$. 


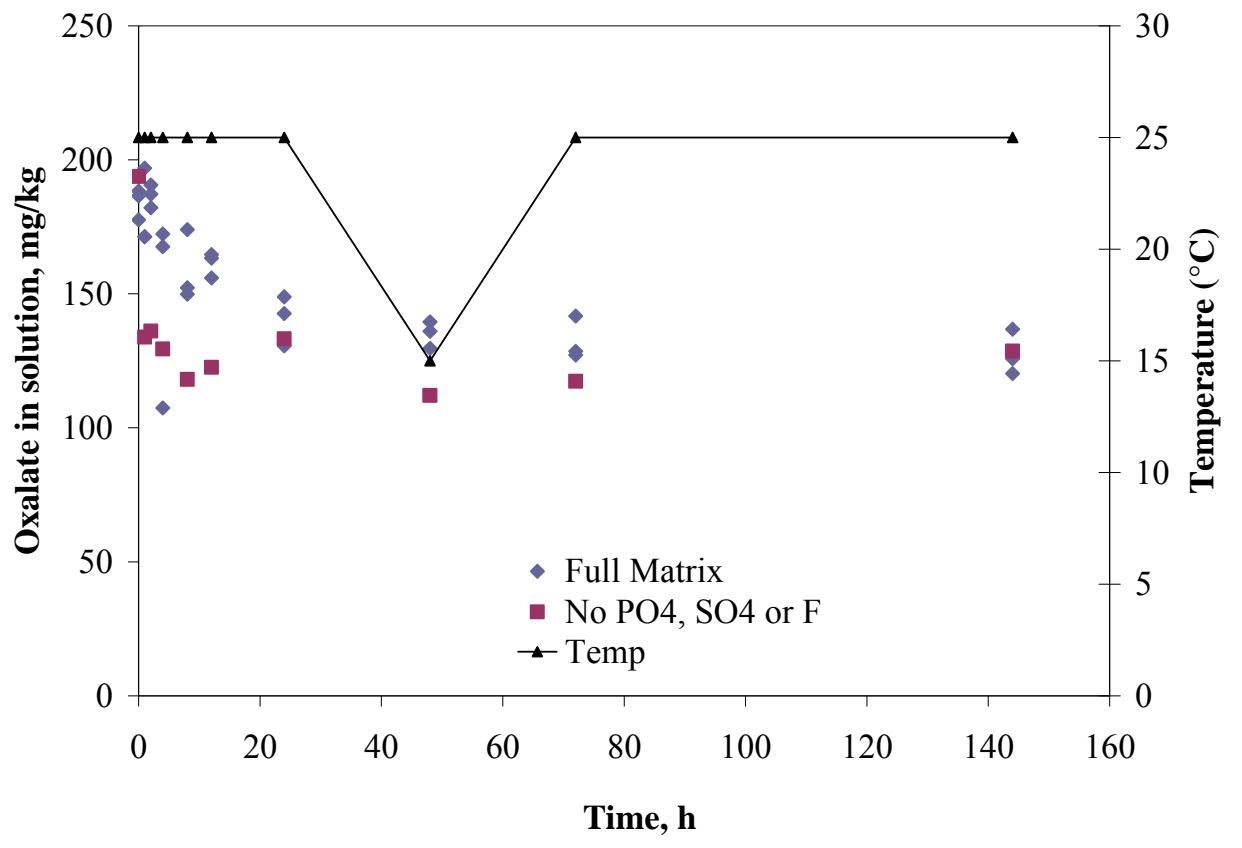

Figure 4.4. Oxalate Precipitation in the Task 2 Tests

Figure 4.5 shows the precipitation of phosphate in the samples. In the absence of fluoride, phosphate appears to equilibrate very quickly. However, in the presence of fluoride, phosphate equilibrates much slower and to a significantly lower solubility. Phosphate solubility appears to be a strong function of fluoride. Figure 4.6 shows the average of the last two phosphate and fluoride measurements from each of these tests that contained both phosphate and fluoride. The solubility of phosphate supersaturation seen for sodium fluoride phosphate is approximately $600-\mathrm{mg} / \mathrm{kg}$. This extent of supersaturation is again significantly more than $10^{\circ} \mathrm{C}$ of supersaturation. The observed saturation at $35^{\circ} \mathrm{C}$ (see Section 5) is approximately $1000-\mathrm{mg} / \mathrm{kg}$, while the initial concentration at $25^{\circ} \mathrm{C}$ was over $1600-\mathrm{mg} / \mathrm{kg}$ in these tests. At $85^{\circ} \mathrm{C}$, the phosphate concentration was approximately $12,000-\mathrm{mg} / \mathrm{kg}$. The initial samples at $25^{\circ} \mathrm{C}$ were very high—greater than $10,000-\mathrm{mg} / \mathrm{kg}$. Then the subsequent samples rapidly reached a steady state value. However, in the absence of fluoride for Tests 2 and 4, there appeared to be some delay in the crystallization. 


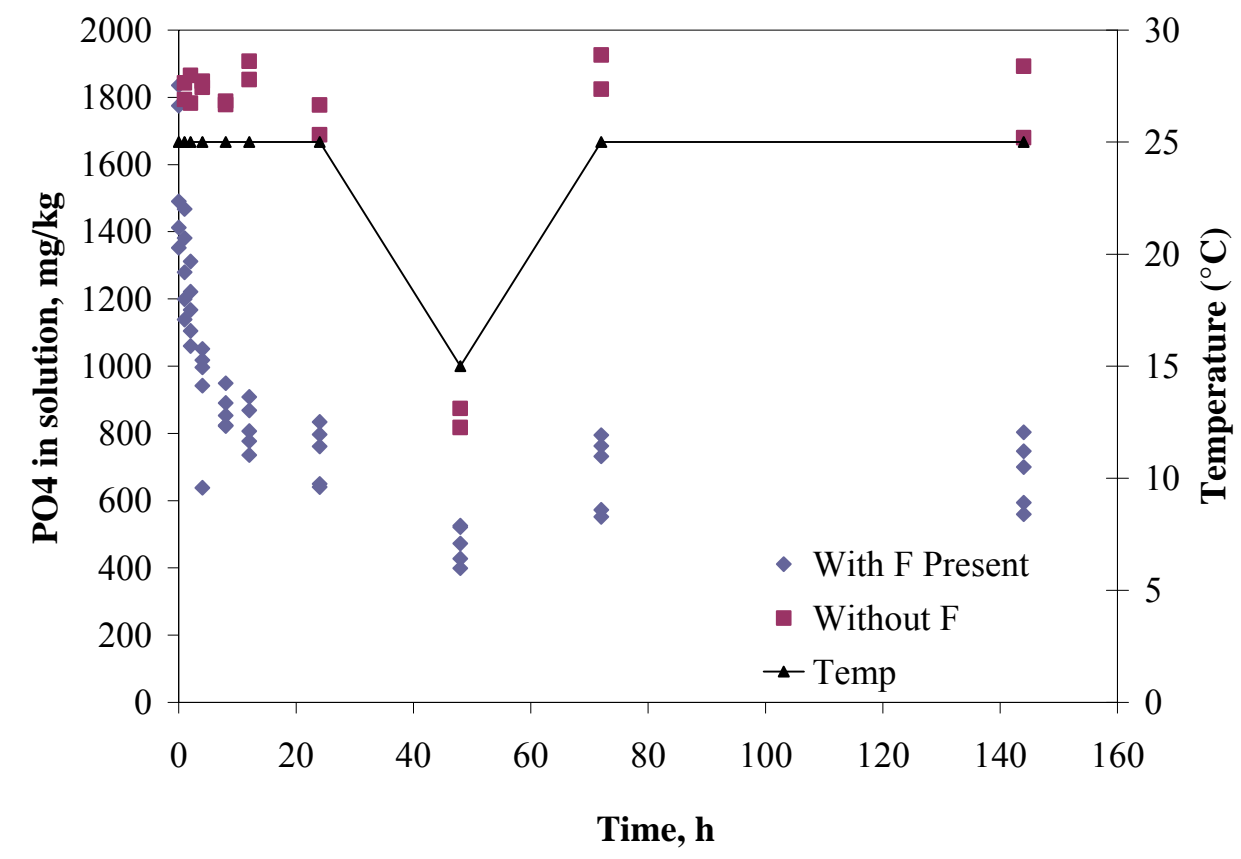

Figure 4.5. Phosphate Precipitation in the Task 2 Tests

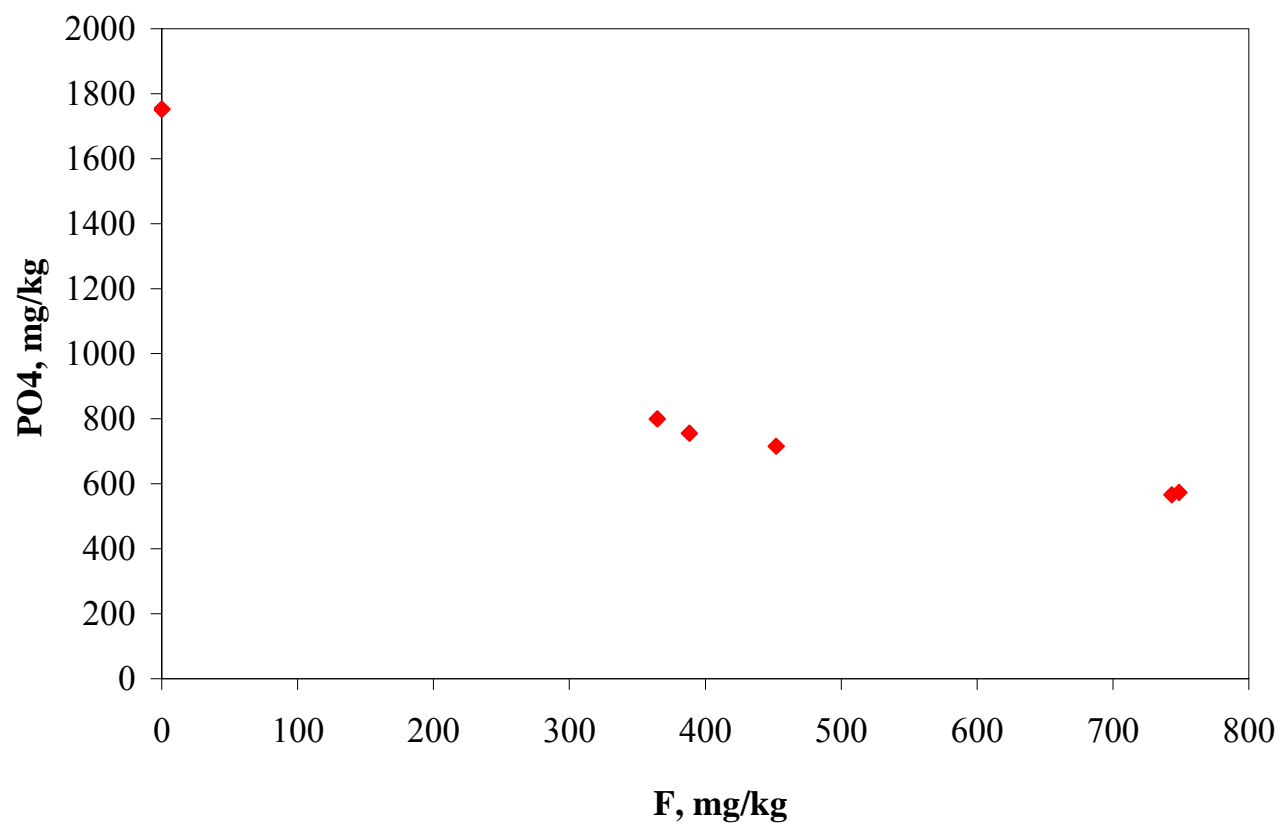

Figure 4.6. Effect of Fluoride Concentration on the Phosphate Concentration 144 Hours After Cooling from $85^{\circ} \mathrm{C}$ to $25^{\circ} \mathrm{C}$ 
Figure 4.7 shows that the presence of fluoride does appear to impact the sulfate solubility by significantly decreasing it. It should be noted that for the tests without fluoride, the quantity of sulfate was likely all of the sulfate in the simulant. As such, this test is not a good measure of sulfate kinetics or solubility, but does indicate that sulfate is very soluble in this matrix.

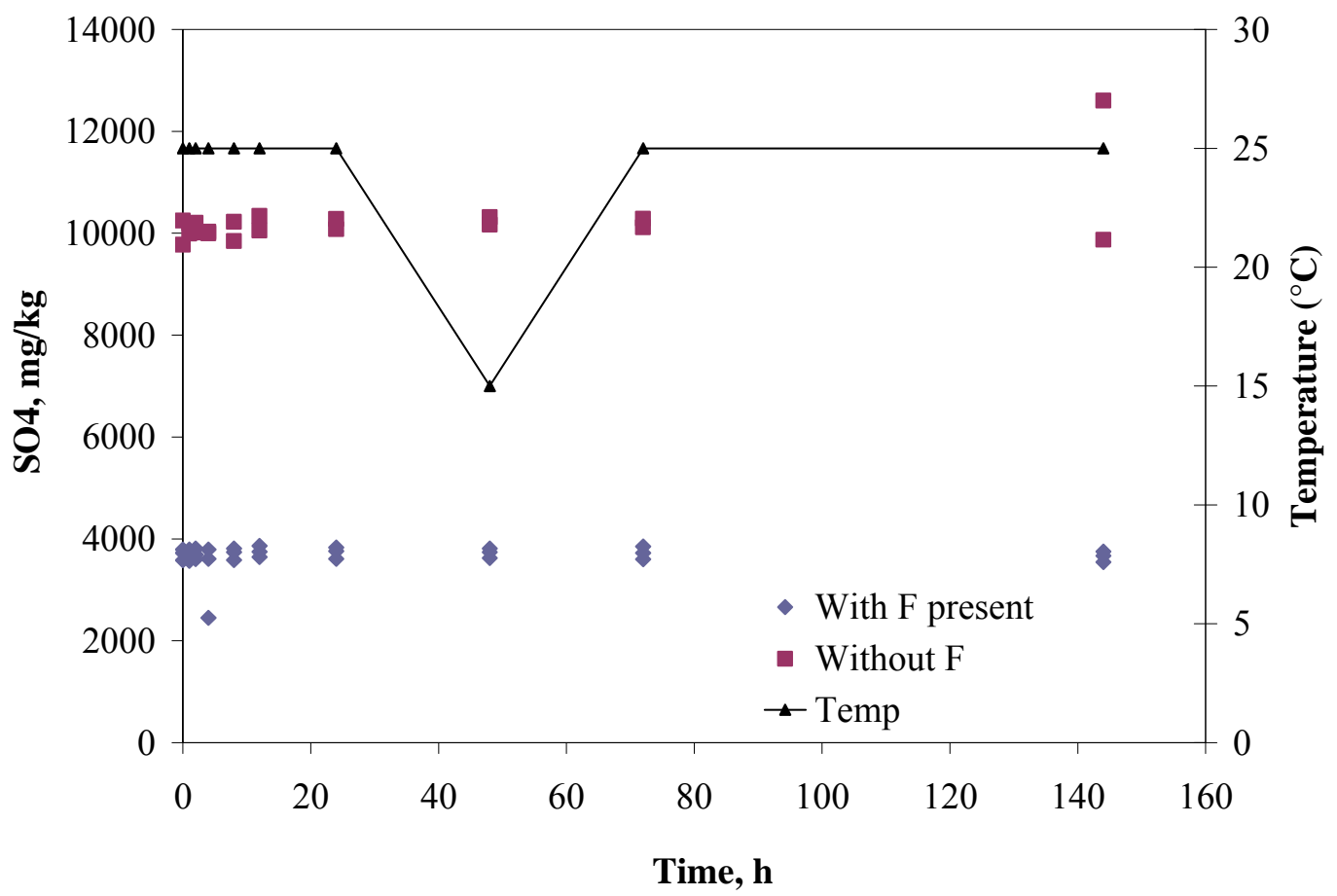

Figure 4.7. Sulfate Precipitation in the Task 2 Tests 
Interestingly, fluoride appears to equilibrate within a few hours for all the samples as shown in Figure 4.8. However, the presence of oxalate appears to impact the fluoride solubility, but fluoride did not impact the oxalate solubility.

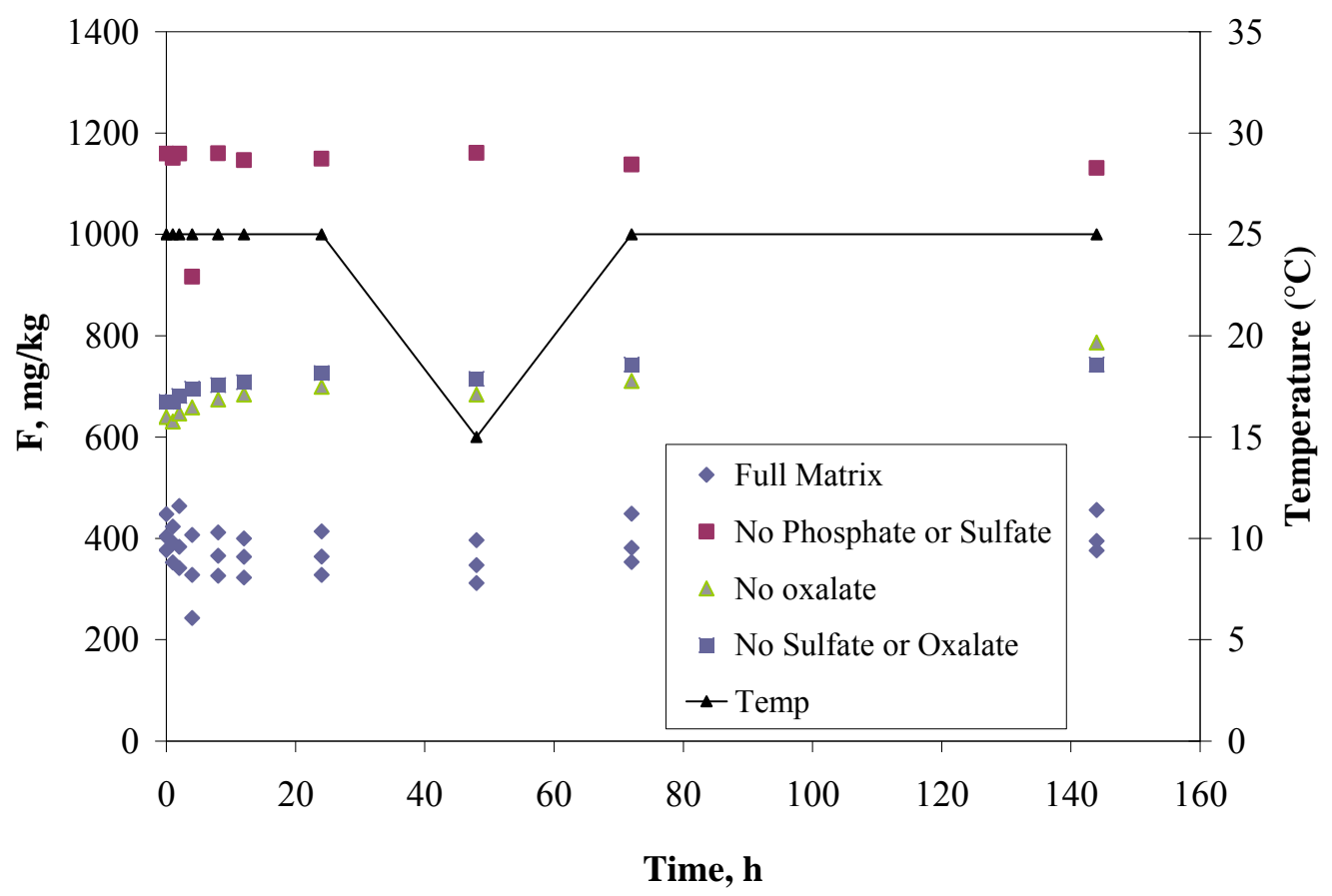

Figure 4.8. Fluoride Precipitation in the Task 2 Tests 


\subsection{Identification and Characterization of Precipitates}

The objective of these tests was to identify precipitates formed at ambient temperature $\left(20^{\circ} \mathrm{C}\right)$ in the presence of phosphate, oxalate, sulfate, silicate, and fluoride anions in the post-caustic leachate solution. These precipitates were also characterized for particle-size distribution (PSD), crystal shape and habit, quantity of precipitate formed, and settling rate. These tests were specified in Test Exception WTP-TEF-RT-09-0001, Rev 1, Task 3 associated with Test Plan TP-WTP-PEP-044, Rev 0.2.

These tests were performed using simulated post-caustic-leach slurry (derived from the PEP Integrated Test A) with the composition shown in Table 4.1. The simulated post-caustic-leach slurry was spiked with each anion of interest (phosphate, oxalate, sulfate, silicate, and fluoride) in the form of a sodium salt as shown in Table 5.1.

Table 5.1. Test Matrix Identification

\begin{tabular}{ccccccc}
\hline & $\begin{array}{c}\text { Post-Caustic- } \\
\text { Leach Slurry } \\
\text { Test ID }\end{array}$ & $\begin{array}{c}\mathrm{Na}_{2} \mathrm{C}_{2} \mathrm{O}_{4}- \\
2 \mathrm{H}_{2} \mathrm{O} \\
(\mathrm{g})\end{array}$ & $\begin{array}{c}\mathrm{Na}_{3} \mathrm{PO}_{4}{ }^{-} \\
12 \mathrm{H}_{2} \mathrm{O} \\
(\mathrm{g})\end{array}$ & $\begin{array}{c}\mathrm{Na}_{2} \mathrm{SO}_{4} \\
(\mathrm{~g})\end{array}$ & $\begin{array}{c}\mathrm{NaF} \\
(\mathrm{g})\end{array}$ & $\begin{array}{c}\mathrm{Na}_{2} \mathrm{SiO}_{3^{-}} \\
9 \mathrm{H}_{2} \mathrm{O} \\
(\mathrm{g})\end{array}$ \\
\hline T3-1a & 1000.03 & 80.88 & 52.63 & 14.75 & 13.59 & 14.33 \\
T3-1b & 1000.04 & 80.88 & 52.63 & 14.75 & 13.59 & 14.33 \\
T3-1c & 1000.02 & 80.88 & 52.63 & 14.75 & 13.59 & 14.33 \\
T3-2 & 1000.02 & 80.88 & 52.63 & 14.75 & 0.00 & 0.00 \\
T3-3 & 1000.05 & 0.00 & 52.63 & 0.00 & 13.59 & 14.33 \\
T3-4 & 1000.03 & 0.00 & 52.63 & 0.00 & 0.00 & 0.00 \\
T3-5 & 1000.01 & 0.00 & 52.63 & 14.75 & 13.59 & 14.33 \\
T3-6 & 1000.03 & 0.00 & 0.00 & 14.75 & 0.00 & 0.00 \\
T3-7 & 1000.00 & 80.88 & 0.00 & 0.00 & 13.59 & 14.33 \\
T3-8 & 1000.01 & 80.88 & 0.00 & 0.00 & 0.00 & 0.00 \\
T3-9 & 1000.04 & 0.00 & 0.00 & 0.00 & 0.00 & 0.00 \\
\hline
\end{tabular}

These slurries were processed as follows:

- All slurries were heated to $35 \pm 1^{\circ} \mathrm{C}$ for 46 hours with shaking.

- All slurries were centrifuged, then filtered through a $0.45-\mu \mathrm{m}$ filter at $35^{\circ} \mathrm{C}$, producing a supernate, which was sampled for IC and ICP (T3-1a-35 ${ }^{\circ} \mathrm{C}$ to T3-9-35 $\left.{ }^{\circ} \mathrm{C}\right)$.

- All slurries were filtered and sampled over a period of 22 hours because of difficulty in filtering iron-containing slurries. Each slurry was filtered over a period of 1 to 2 hours at $35 \pm 5^{\circ} \mathrm{C}$.

- All supernates were split into two samples, the smaller for settling tests and the larger for all other testing.

- All supernates were cooled to $20^{\circ} \mathrm{C}$ with shaking and held there for 92 to 96 hours and then sampled for IC and ICP (T3-1a- $20^{\circ} \mathrm{C}$ to $\left.\mathrm{T} 3-9-20^{\circ} \mathrm{C}\right)$. 
- Supernates that did not produce crystals during the first hold (T3-2, T3-6, T3-7, T3-8, and T3-9) were seeded from T3-4 and T3-1a and held at $20^{\circ} \mathrm{C}$ for another 96 hours.

- Settling tests were performed per discussion below.

These test samples were placed in the incubator at $35 \pm 1{ }^{\circ} \mathrm{C}$ and held there for at least 46 hours while shaking at $150 \mathrm{rpm}$. After 46 hours, the test samples were first centrifuged and then filtered through a $0.45-\mu \mathrm{m}$ filter at $35^{\circ} \mathrm{C}$, and an aliquot was taken for analysis by placing approximately $1.5-\mathrm{mL}$ of supernate (filtered through a $0.45-\mu \mathrm{m}$ filter) into a sample bottle containing approximately $15-\mathrm{mL}$ of DIW to dilute it approximately 10 times. This filtering was very difficult because of filter clogging from the iron oxyhydroxide present in the slurry. Multiple filters were used during the filtering of each test sample, which required more time per analytical sample ( $\sim 1$ to 2 hours), increasing the test sample time at $35 \pm 1{ }^{\circ} \mathrm{C}$. This analytical sample collecting was continued over 22 hours before all of the test samples were filtered. Immediately after filtering, the test samples were split by pouring the supernate into two bottles - one 250-mL bottle and one 1-L bottle. The smaller bottle was used for the settling test and the crystal size testing. The larger bottle was used for all of the other analyses. The filtered test samples were cooled to $20^{\circ} \mathrm{C}$ in the incubator over 5 hours while shaking at $165 \mathrm{rpm}$. After being held at $20^{\circ} \mathrm{C}$ for 92 to 96 hours, another sample was taken by placing approximately $1.5-\mathrm{mL}$ of supernate (filtered through a $0.45-\mu \mathrm{m}$ filter) into a sample bottle containing approximately $15-\mathrm{mL}$ of DIW to dilute it approximately 10 times. These samples were submitted for ICP analysis of Al, Na, S, Si, Fe, K, and P and for IC analysis of oxalate, phosphate, sulfate, nitrate, nitrite, and fluoride. These results are shown in Appendix A, Table A.3, and Table A.4, respectively.

The test precipitate results are shown in Table 5.2. Tests T3-2, T3-6, T3-7, T3-8, and T3-9 did not produce solids. Test T3-4 with only phosphate added produced the most solids (see Figure 5.1). Tests T3-1a, T3-1b, T3-1c, T3-3, and T3-5 only produced approximately 1-mL or less of solids. Tests T3-2, T3-6, T3-7, T3-8, and T3-9 were seeded with a drop of supernate containing crystals from each of Test T3-4 and T3-1a and allowed to mix over the weekend. However, they still did not produce any crystals after 96 hours at $20^{\circ} \mathrm{C}$.

Table 5.2. Test Precipitate Results

\begin{tabular}{lccc}
\hline Test ID & Precipitate Formed? & $\begin{array}{c}\text { Amount of } \\
\text { Precipitate }(\mathrm{g})\end{array}$ & Type of Precipitate \\
\hline T3-1a & Yes & 1.61 & $\mathrm{Na}_{7} \mathrm{~F}\left(\mathrm{PO}_{4}\right)_{2} \cdot 19 \mathrm{H}_{2} \mathrm{O}$ \\
T3-1b & Yes & 1.15 & $\mathrm{Na}_{7} \mathrm{~F}\left(\mathrm{PO}_{4}\right)_{2} \cdot 19 \mathrm{H}_{2} \mathrm{O}$ \\
T3-1c & Yes & 1.24 & $\mathrm{Na}_{7} \mathrm{~F}\left(\mathrm{PO}_{4}\right)_{2} \cdot 19 \mathrm{H}_{2} \mathrm{O}$ \\
T3-2 & No & 0.112 & $\mathrm{NA}$ \\
T3-3 & Yes & 2.33 & $\mathrm{Na}_{7} \mathrm{~F}\left(\mathrm{PO}_{4}\right)_{2} \cdot 19 \mathrm{H}_{2} \mathrm{O}$ \\
T3-4 & Yes & 14.9 & $\mathrm{Na}_{3} \mathrm{PO}_{4} \cdot 12 \mathrm{H}_{2} \mathrm{O}$ \\
T3-5 & Yes & 0.176 & $\mathrm{Na}_{7} \mathrm{~F}\left(\mathrm{PO}_{4}\right)_{2} \cdot 19 \mathrm{H}_{2} \mathrm{O}$ \\
T3-6 & No & 0.112 & NA \\
T3-7 & No & 0.104 & NA \\
T3-8 & No & 0.100 & NA \\
T3-9 & No & 0.110 & NA \\
\hline
\end{tabular}


In the settling test, the samples with just the small amount of solids settled in 2 to 3 minutes. These tests settled so fast and with such little solids that it was not possible to obtain a settling curve. Test T3-4 settled with an interface where the majority of the solids settled, but the supernate above them remained cloudy longer as shown in Figure 5.2. The settling curves for Test T3-4 are shown in Figure 5.3 and Figure 5.4.

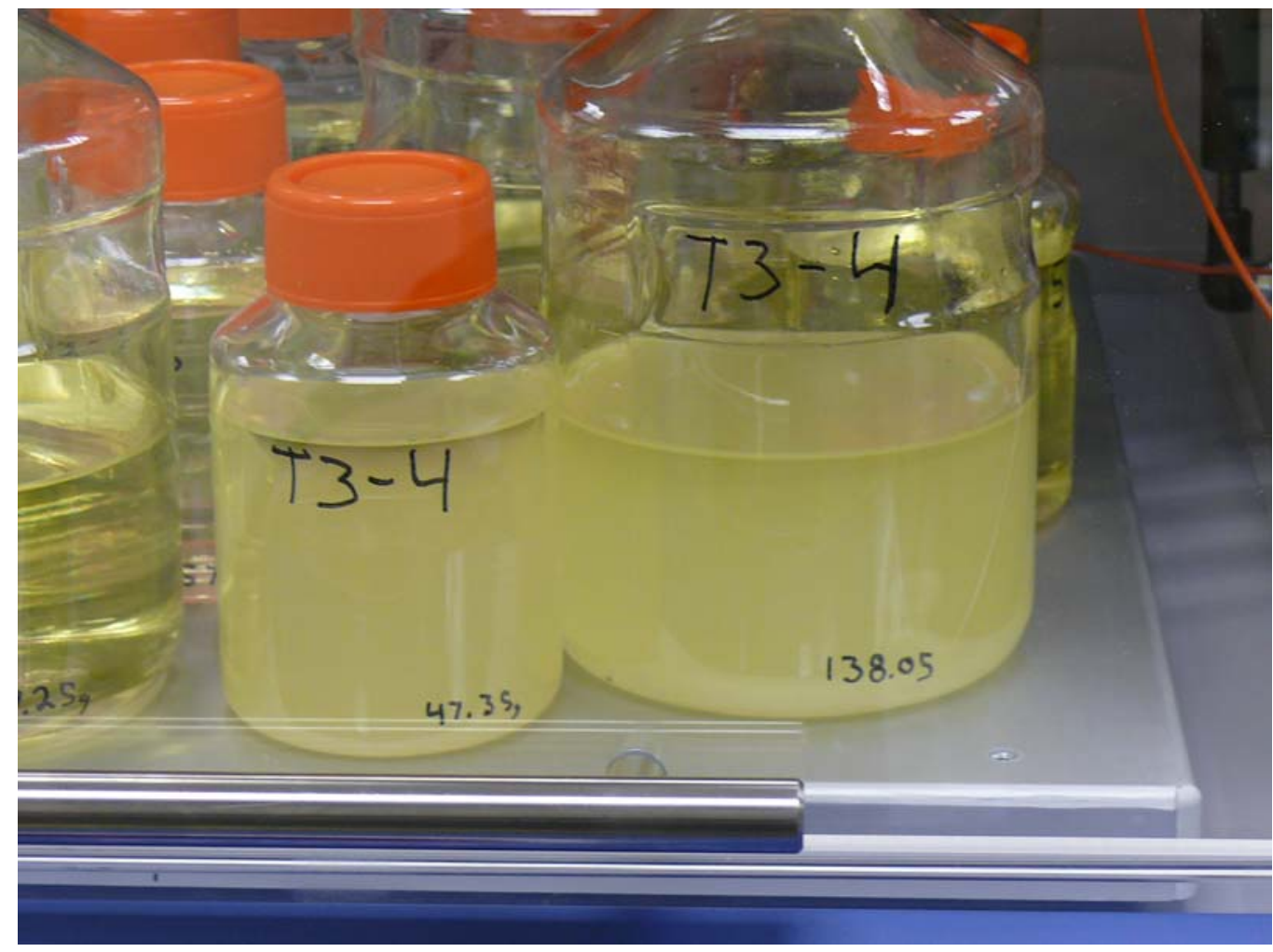

Figure 5.1. Solids Produced in Test T3-4 (Spiked with Sodium Phosphate) 


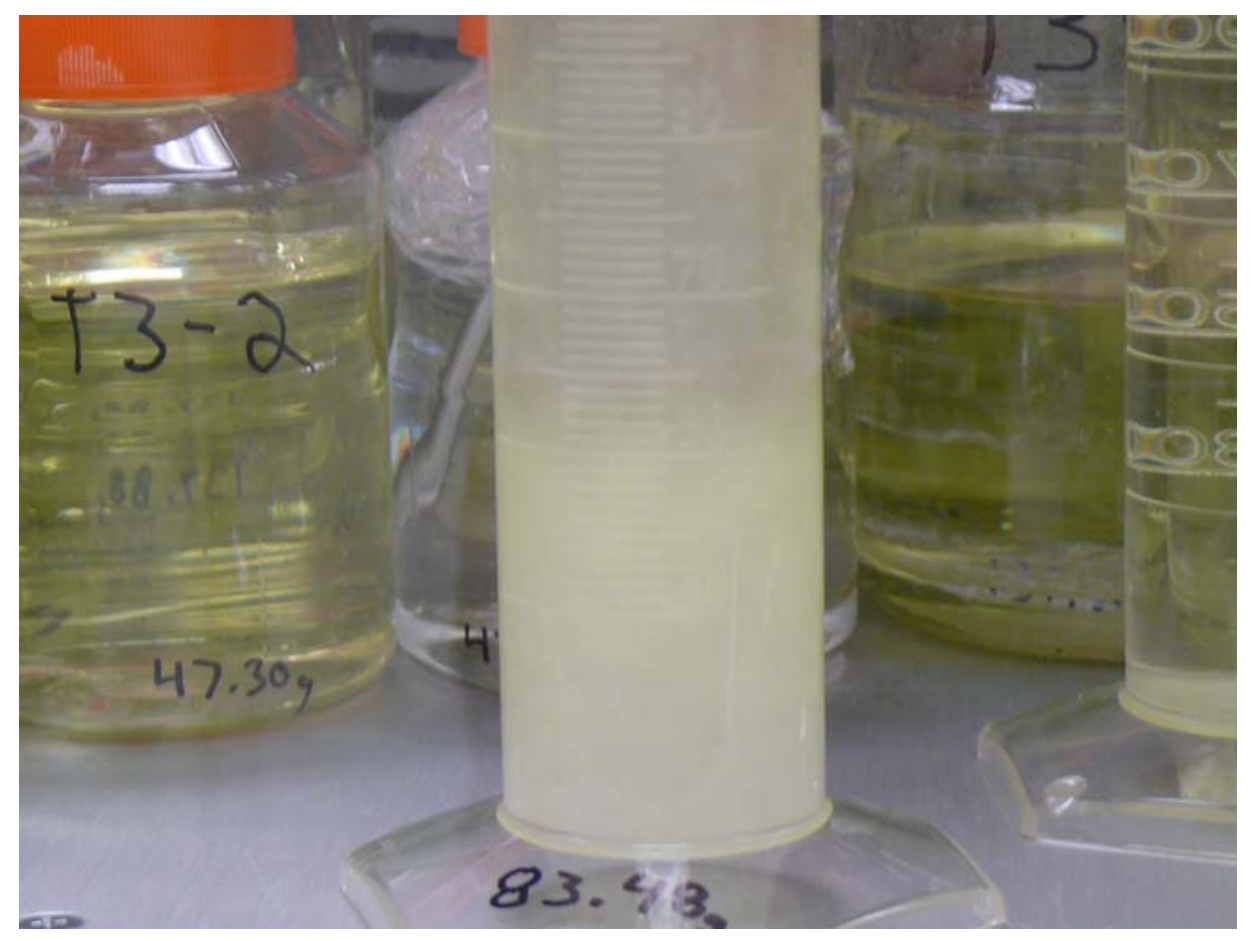

Figure 5.2. Test T3-4 (Spiked with Sodium Phosphate) Solids Settling

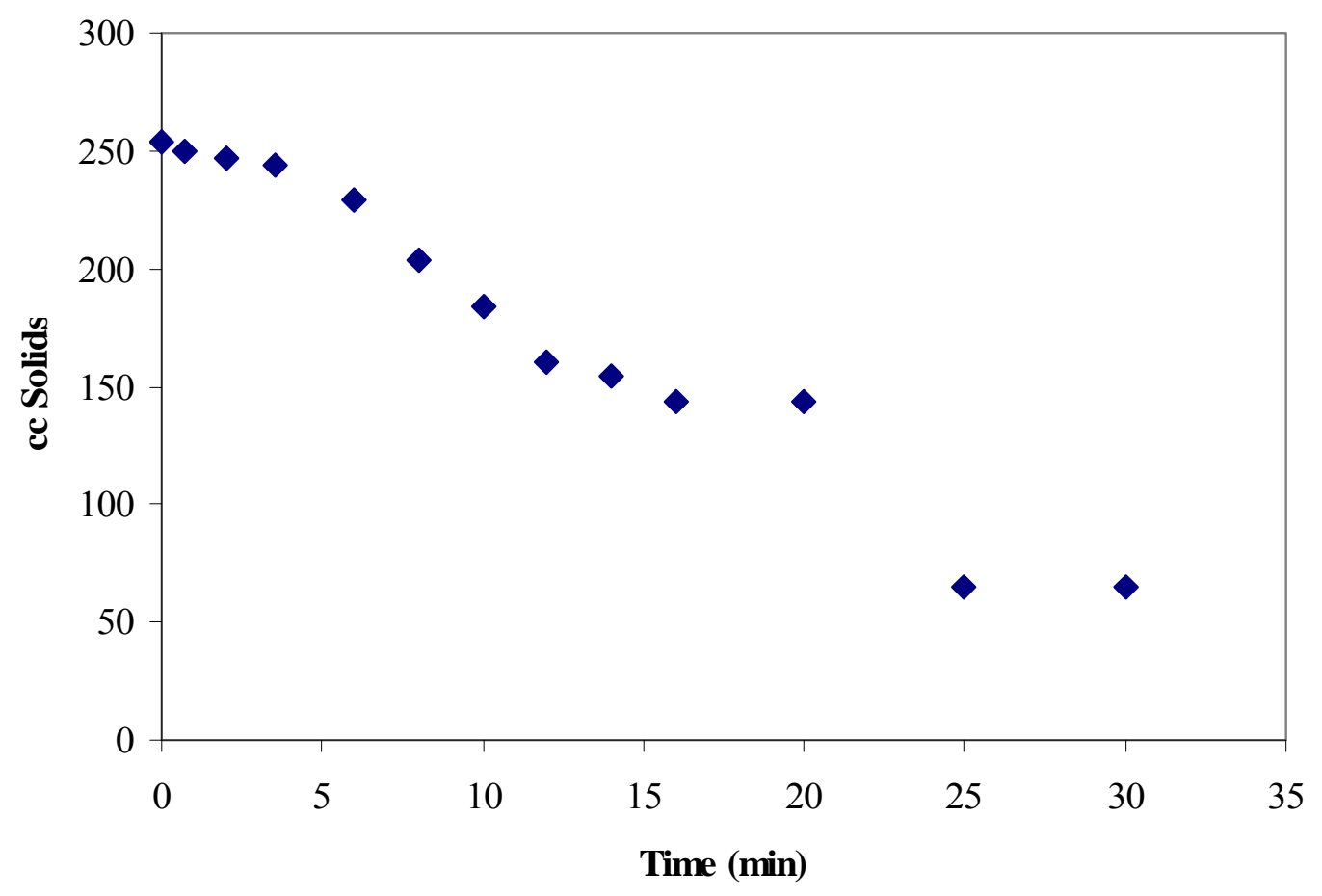

Figure 5.3. Initial Settling Rate of Test T3-4 (Spiked with Sodium Phosphate) 


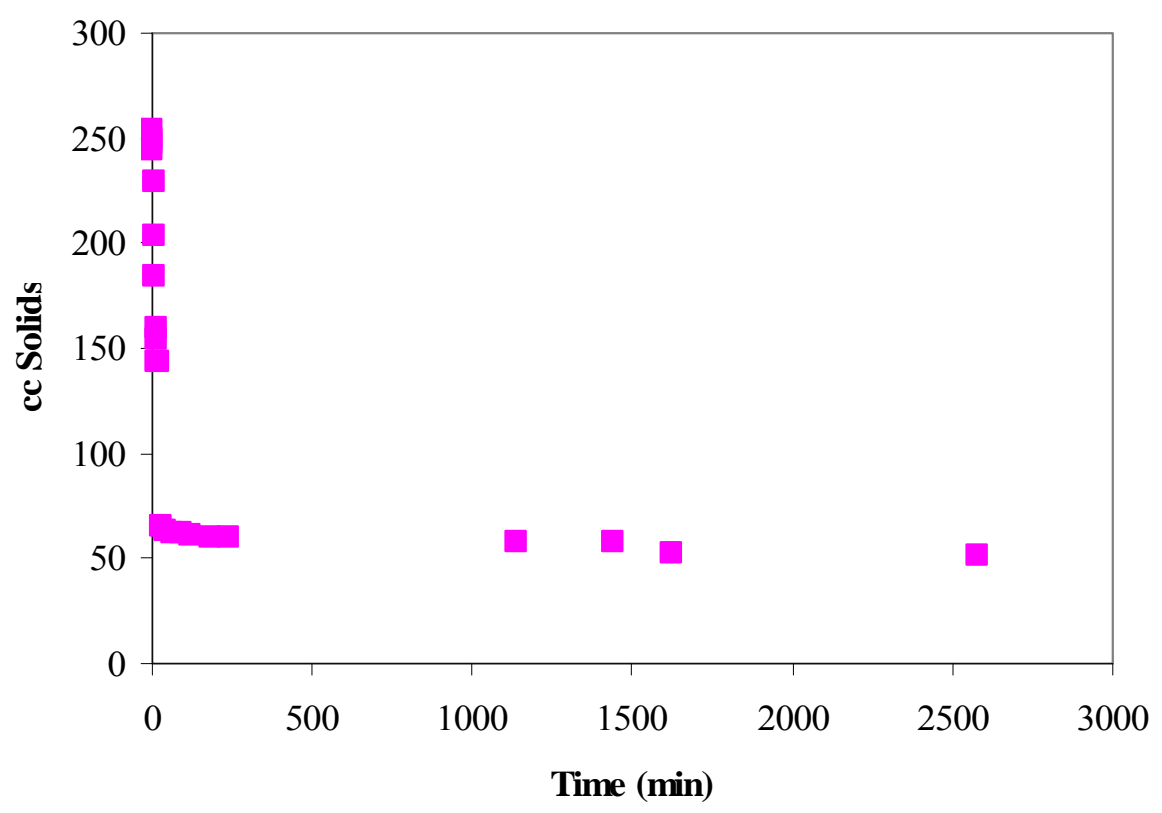

Figure 5.4. Overall Settling Rate of Test T3-4 (Spiked with Sodium Phosphate)

Table 5.3 provides the measured difference in ion concentrations between the $35^{\circ} \mathrm{C}$ and $20^{\circ} \mathrm{C}$ samples where a greater amount of precipitation was expected with a higher concentration difference. The blank entries represent tests where the species of interest was omitted from the slurry matrix. This table indicates that Tests T3-1a, T3-1b, T3-1c, T3-3, T3-4, and T3-5 should have a significant amount of precipitation. Tests T3-2, T3-7, and T3-8 should have a small amount of precipitation with Test T3-6 and Test T3-9 having no precipitation. These results indicate that very low quantities of oxalate and sulfate will precipitate upon cooling. The results indicate that larger quantities of sodium fluoride phosphate will precipitate upon cooling.

Table 5.3. Measured Difference in Ion Concentration between $35^{\circ} \mathrm{C}$ and $20^{\circ} \mathrm{C}$

\begin{tabular}{lccccc}
\hline Test ID & $\begin{array}{c}\mathrm{F} \\
(\mu \mathrm{g} / \mathrm{g})\end{array}$ & $\begin{array}{c}\mathrm{C}_{2} \mathrm{O}_{4} \\
(\mu \mathrm{g} / \mathrm{g})\end{array}$ & $\begin{array}{c}\mathrm{PO}_{4} \\
(\mu \mathrm{g} / \mathrm{g})\end{array}$ & $\begin{array}{c}\mathrm{SO}_{4} \\
(\mu \mathrm{g} / \mathrm{g})\end{array}$ & $\begin{array}{c}\text { Amt of } \\
\text { Precip. }(\mathrm{g})\end{array}$ \\
\hline T3-1a & 62 & 25 & 590 & -20 & 1.61 \\
T3-1b & 24 & 7 & 315 & -16 & 1.15 \\
T3-1c & 21 & -5 & 265 & -43 & 1.24 \\
T3-2 & - & 9 & 19 & 4 & 0.112 \\
T3-3 & 84 & - & 876 & - & 2.33 \\
T3-4 & - & - & 2906 & - & 14.9 \\
T3-5 & 79 & - & 817 & 13 & 0.176 \\
T3-6 & - & - & - & -94 & 0.112 \\
T3-7 & -6 & 14 & - & - & 0.104 \\
T3-8 & - & 15 & - & - & 0.100 \\
T3-9 & - & - & - & - & 0.110 \\
\hline
\end{tabular}


Sodium phosphate solubility from the results of Tasks 2 and 3 tests is shown in Figure 5.5. The amount of phosphate in solution at $35^{\circ} \mathrm{C}$ in Test T3-2 appears to be anomalously low. At this point, there is not a good reason why this value was low, but the sample did not appear to be at equilibrium at $35^{\circ} \mathrm{C}$. This may be due to either the sample re-equilibrating quickly upon cooling during the separation process or the sample not yet reaching equilibrium during storage at temperature. The amount of phosphate in solution is about $1 / 4$ of the expected amount based on Test T3-4 (phosphate only test).

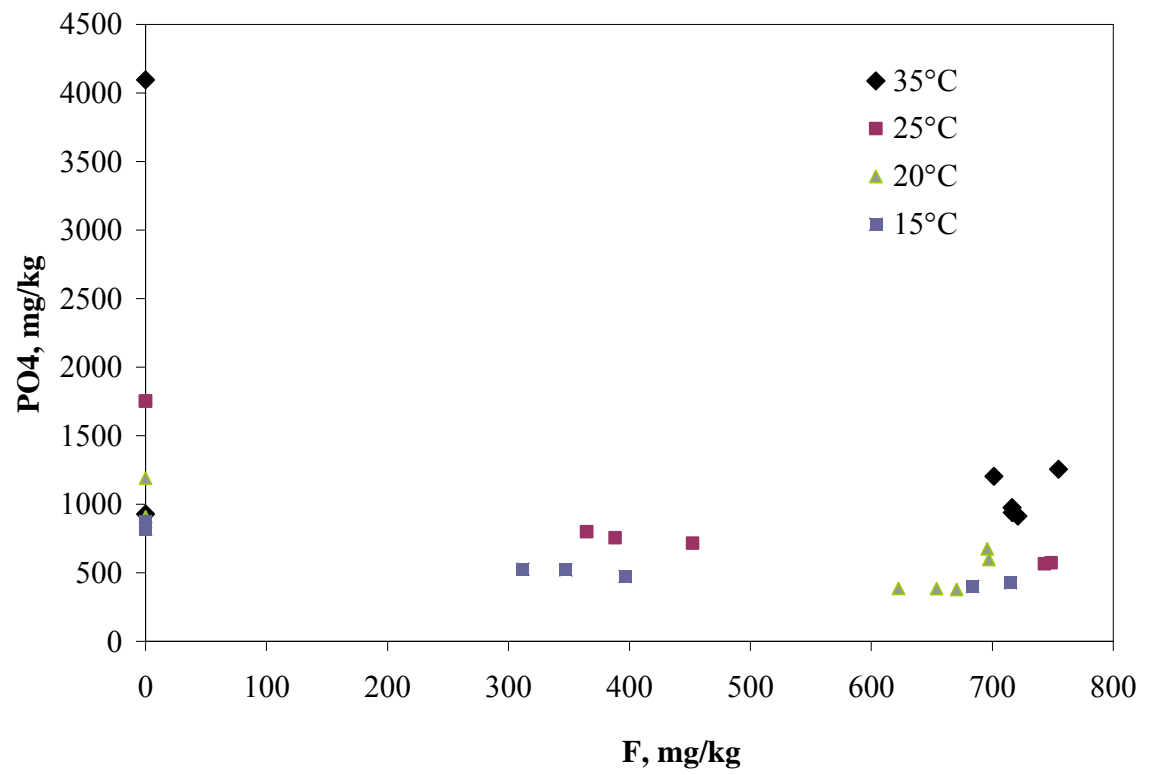

Figure 5.5. Phosphate Solubility

Figure 5.6 shows the impact of temperature on solubility of the different anions measured at 24 hours from Task 2 for $15^{\circ} \mathrm{C}$ and $25^{\circ} \mathrm{C}$ (see Section 4 ) and Task 3 for $20^{\circ} \mathrm{C}$ and $35^{\circ} \mathrm{C}$. This shows that only sodium phosphate and sodium fluoride phosphate exhibit any significant change in solubility with temperature. The other main components appear to be relatively insensitive to temperature. 


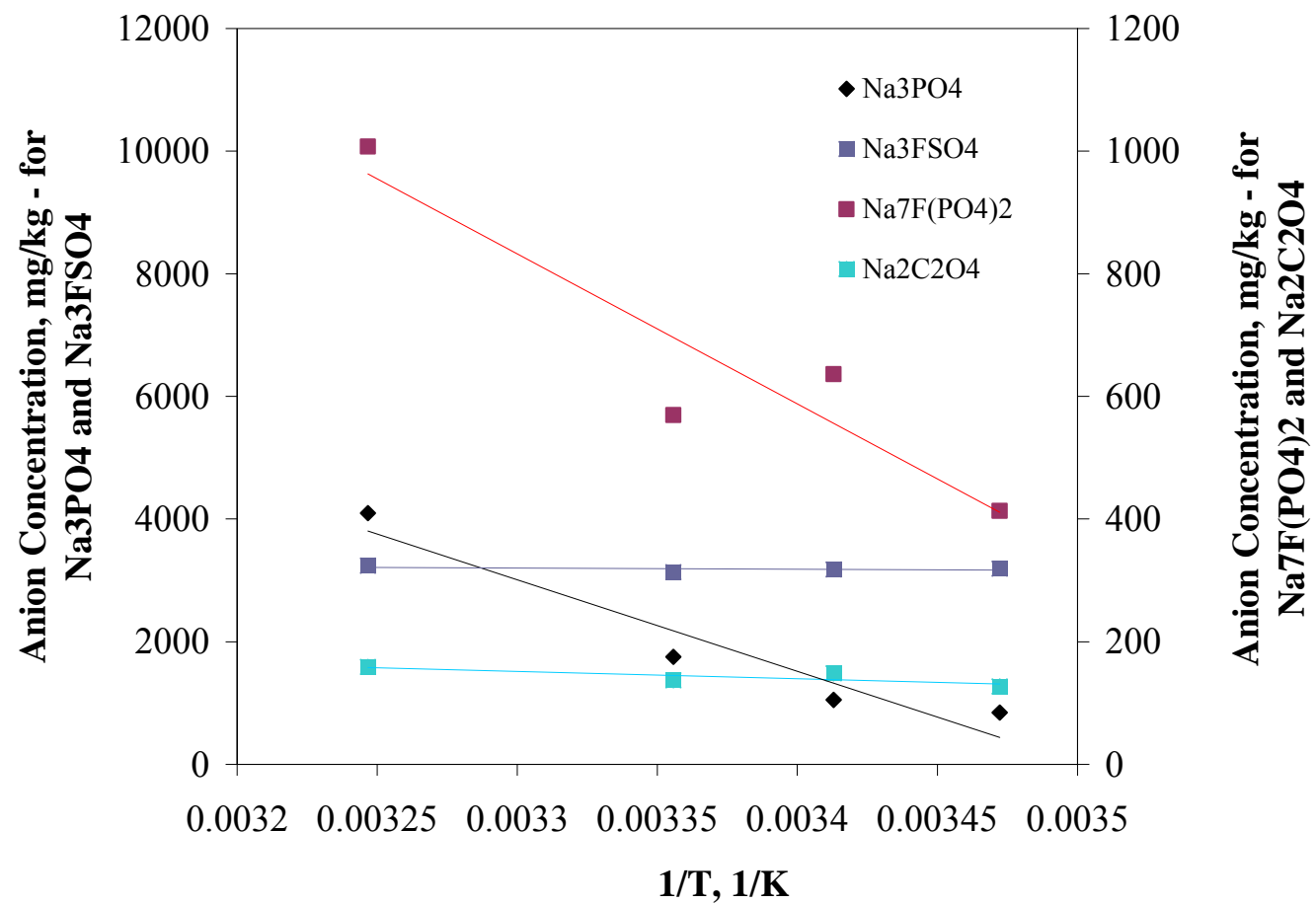

Figure 5.6. Impact of Temperature on Solubility Measured at 24 Hours

Task 3 sample solutions containing precipitated crystals were analyzed by OM to gather optical properties of the crystals as well as particle size. All of the Task 3 samples, with the exception of T3-4, contained the same cubic crystal type as shown in Figure 5.7 through Figure 5.11. The crystals were determined to be cubic because of the observed morphology when under cross-polarized light is extinct at all angles. These crystals are likely $\mathrm{Na}_{7} \mathrm{~F}\left(\mathrm{PO}_{4}\right)_{2} \cdot 19 \mathrm{H}_{2} \mathrm{O}$ based on the high refractive index of the crystals. 


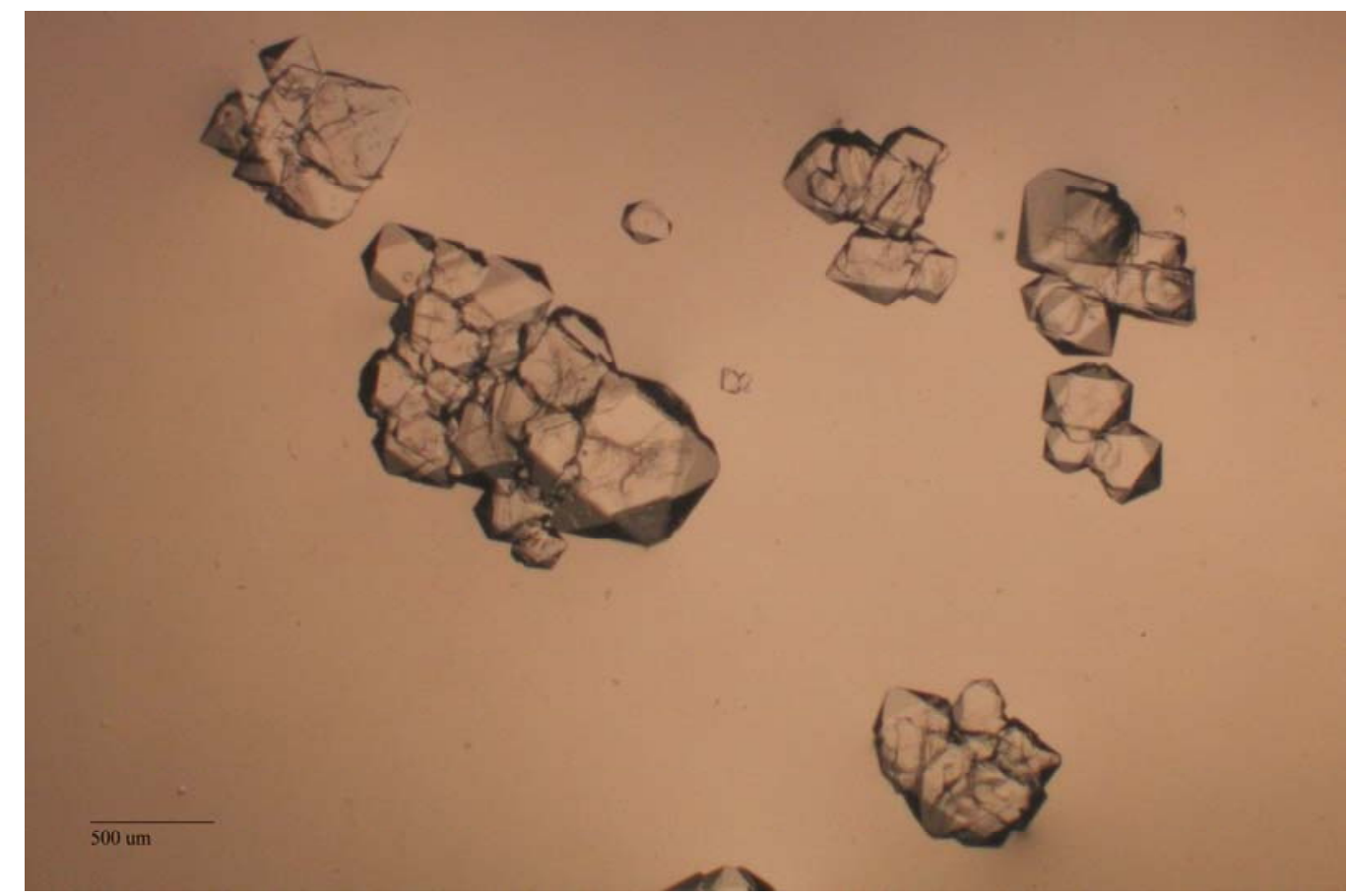

Figure 5.7. Sample T3-1a $\left(\mathrm{Na}_{7} \mathrm{~F}\left(\mathrm{PO}_{4}\right)_{2} \cdot 19 \mathrm{H}_{2} \mathrm{O}\right) \mathrm{OM}$ in Polarized Light

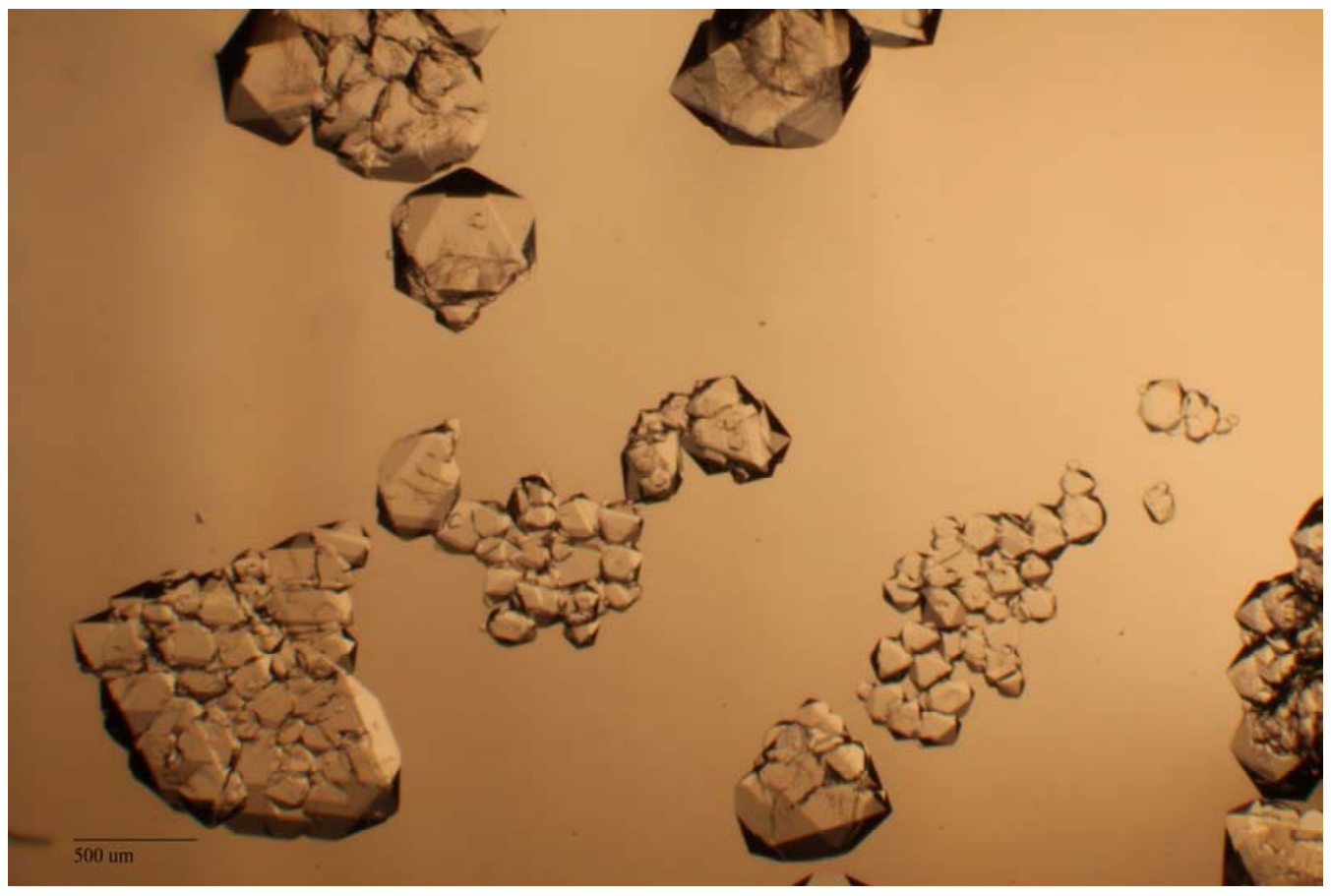

Figure 5.8. Sample $\mathrm{T} 3-1 \mathrm{~b}\left(\mathrm{Na}_{7} \mathrm{~F}\left(\mathrm{PO}_{4}\right)_{2} \cdot 19 \mathrm{H}_{2} \mathrm{O}\right) \mathrm{OM}$ in Polarized Light 


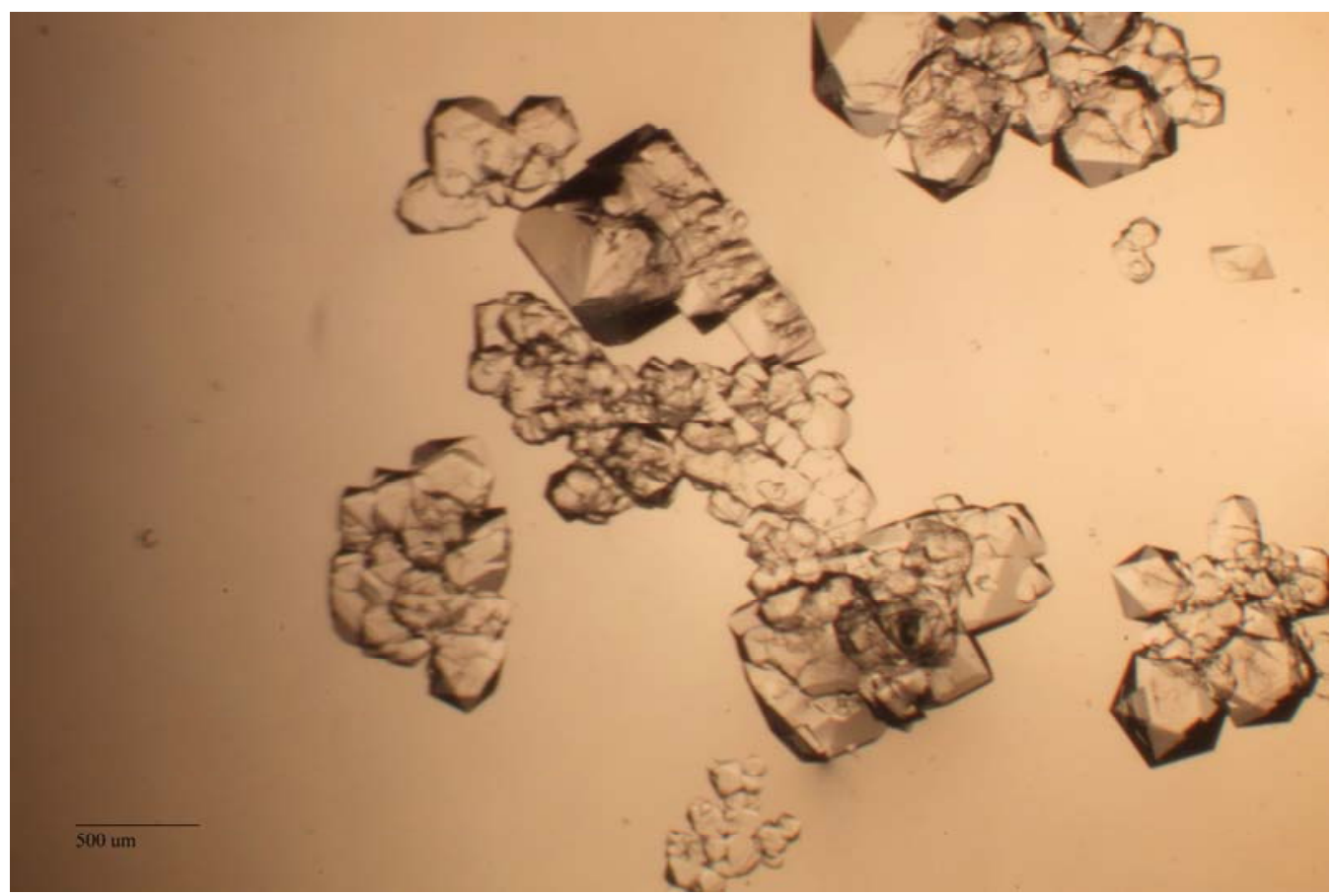

Figure 5.9. Sample T3-1c $\left(\mathrm{Na}_{7} \mathrm{~F}\left(\mathrm{PO}_{4}\right)_{2} \cdot 19 \mathrm{H}_{2} \mathrm{O}\right) \mathrm{OM}$ in Polarized Light

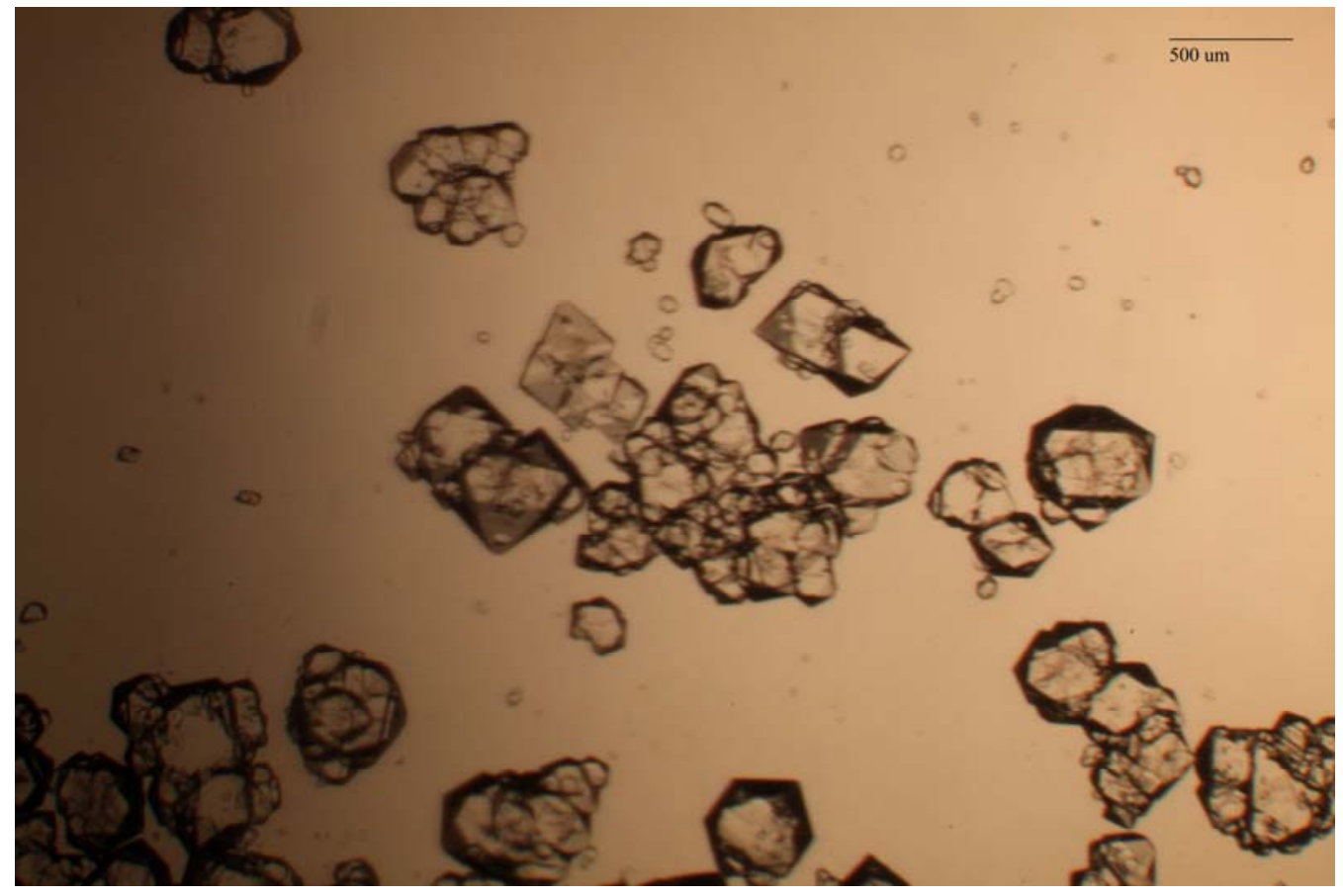

Figure 5.10. Sample $\mathrm{T} 3-3\left(\mathrm{Na}_{7} \mathrm{~F}\left(\mathrm{PO}_{4}\right)_{2} \cdot 19 \mathrm{H}_{2} \mathrm{O}\right) \mathrm{OM}$ in Polarized Light 


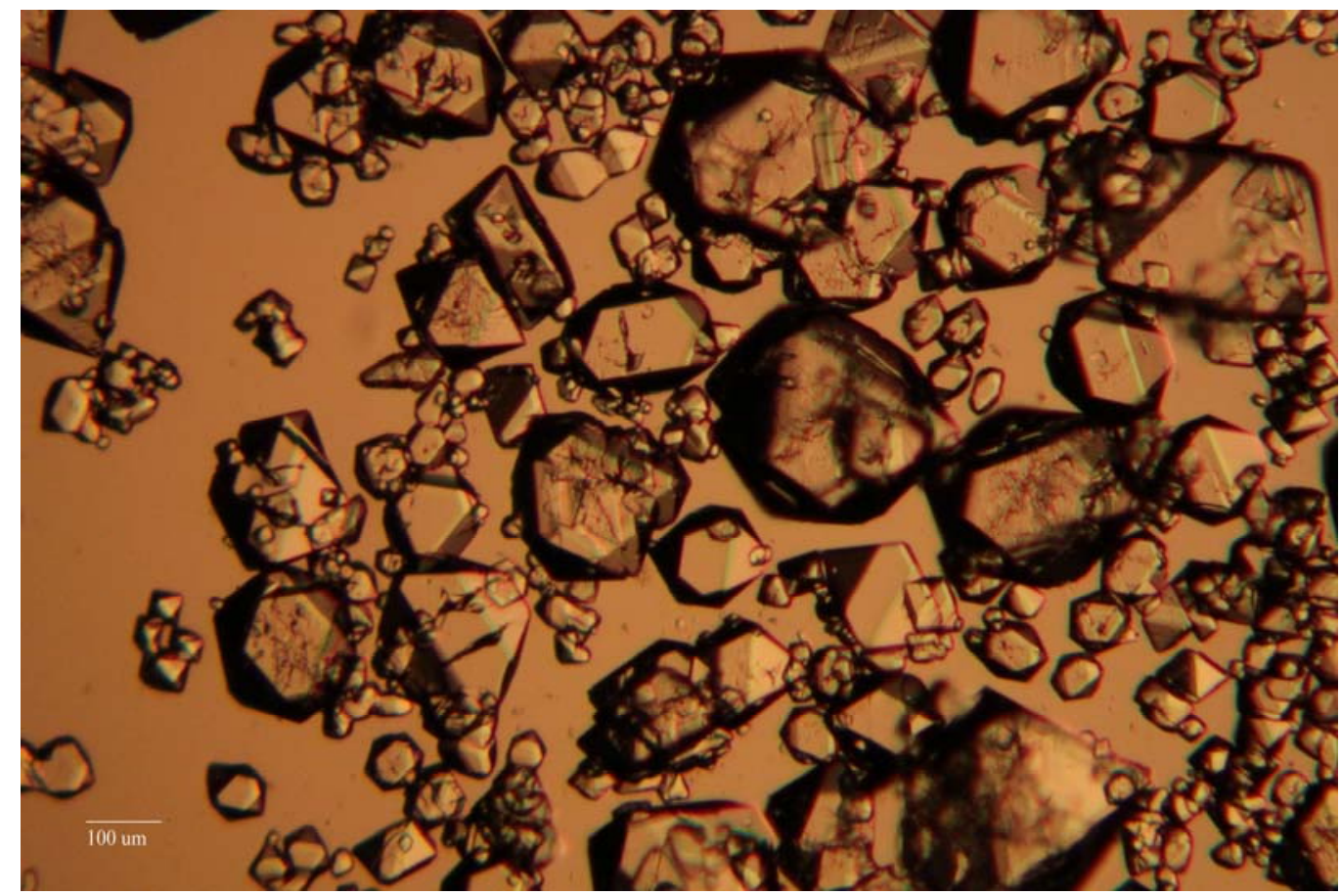

Figure 5.11. Sample T3-5 $\left(\mathrm{Na}_{7} \mathrm{~F}\left(\mathrm{PO}_{4}\right)_{2} \cdot 19 \mathrm{H}_{2} \mathrm{O}\right) \mathrm{OM}$ in Polarized Light

Sample T3-4 contains long, thin, needle-shaped crystals that appear white under cross-polarized light as shown in Figure 5.12. When a full wave plate is inserted into the cross-polarized light, the crystals appear blue when the long axis of the crystal and the wave plate are parallel, and yellowish-orange when perpendicular, as shown in Figure 5.13. Therefore, these crystals are most likely $\mathrm{Na}_{3} \mathrm{PO}_{4} \cdot 12 \mathrm{H}_{2} \mathrm{O}$.

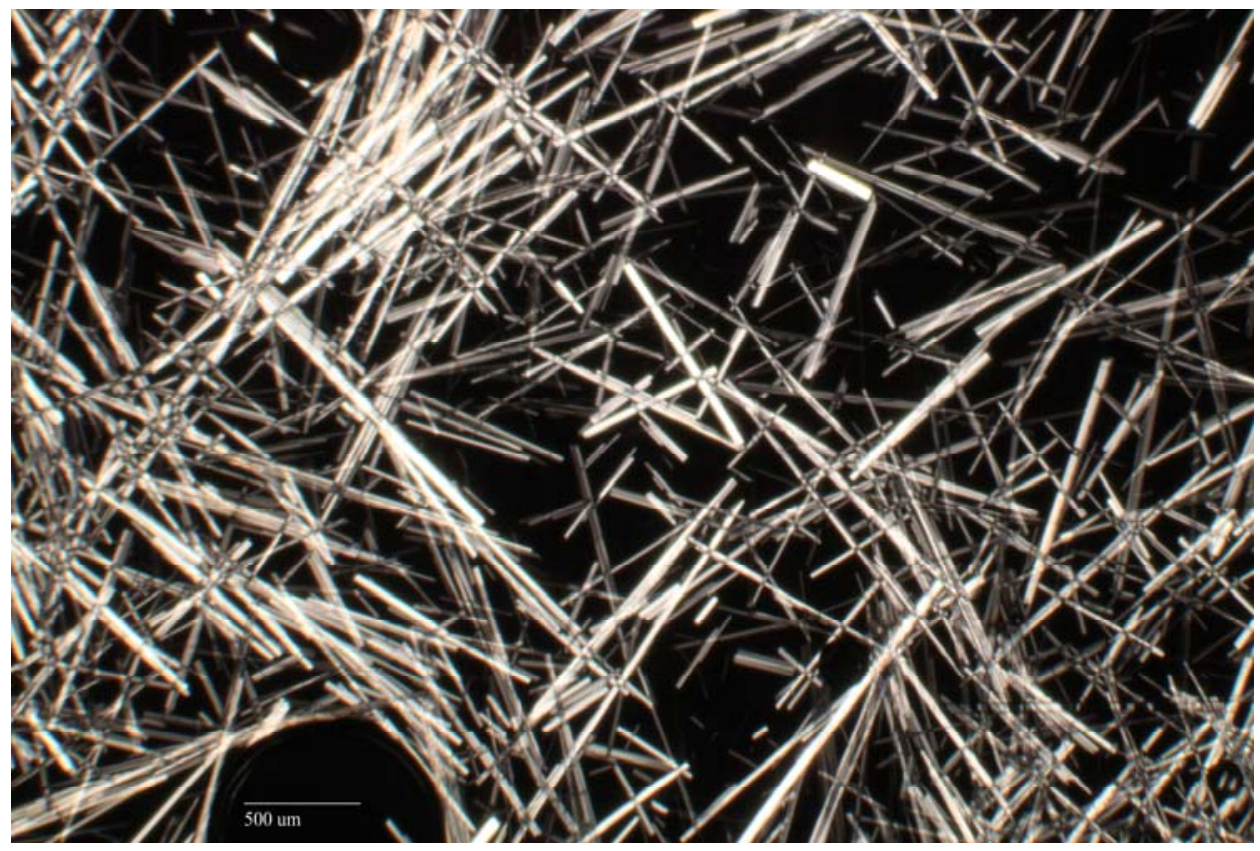

Figure 5.12. Sample T3-4 in $\left(\mathrm{Na}_{3} \mathrm{PO}_{4} \cdot 12 \mathrm{H}_{2} \mathrm{O}\right)$ OM Cross-Polarized Light 


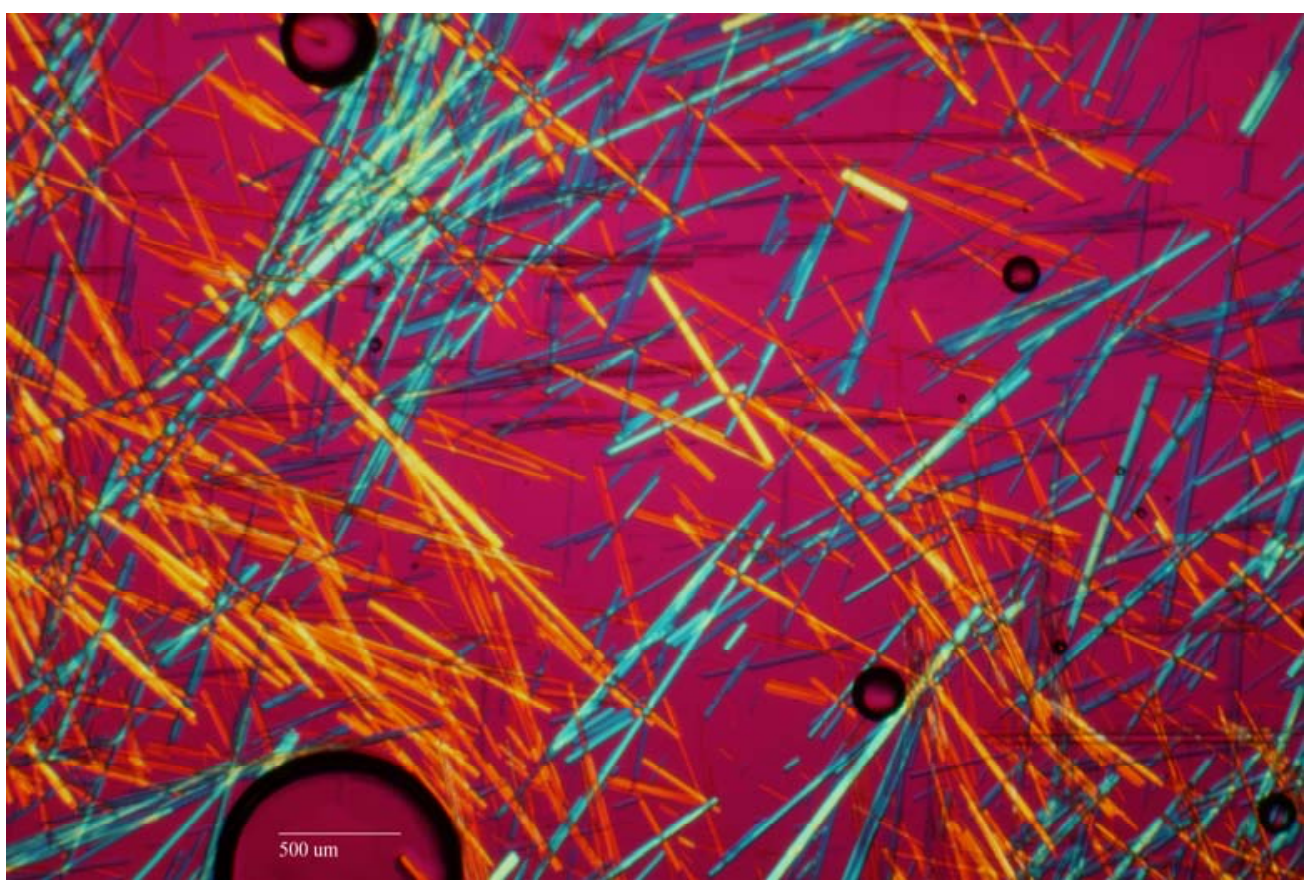

Figure 5.13. Sample T3-4 $\mathrm{Na}_{3} \mathrm{PO}_{4} \cdot 12 \mathrm{H}_{2} \mathrm{O}$ Crystals in OM Cross-Polarized Light with Full Wave Plate

Particle size analysis was performed using I-mage software on polarized light micrographs. Particles were fit manually with the polygon, circle, or ellipse functions. The cubic crystals appear to nucleate and grow from existing crystals and as a result significantly interfere with the size measurements of the individual crystals. Often the size of the combined group of crystals was all that could be accurately measured for the cubic crystals. In the case of T3-4, the crystals were individually fit as it is much easier to distinguish individual crystals when overlap occurs. The software then calculated the crystal area, maximum length, and maximum width with a summary of these results shown in Table 5.4. The complete results are shown in Appendix A, Table A14 through Table A.19. 
Table 5.4. Summary Table of Measured Crystal Dimensions for Each Sample

\begin{tabular}{|c|c|c|c|c|c|c|}
\hline Sample \# & Particle Mineralogy & $\begin{array}{c}\text { \# of } \\
\text { Particles }\end{array}$ & $\begin{array}{c}\text { Statistical } \\
\text { Measure }\end{array}$ & Area, $\mu \mathrm{m}^{2}$ & $\begin{array}{c}\text { Max } \\
\text { Length, } \\
\mu \mathrm{m}\end{array}$ & $\begin{array}{c}\text { Max } \\
\text { Width, } \mu \mathrm{m}\end{array}$ \\
\hline \multirow{3}{*}{ T3-1a } & \multirow{3}{*}{$\mathrm{Na}_{7} \mathrm{~F}\left(\mathrm{PO}_{4}\right)_{2} \cdot 19 \mathrm{H}_{2} \mathrm{O}$} & \multirow{3}{*}{28} & Mean & 201,352 & 556 & 410 \\
\hline & & & Min & 8,776 & 126 & 95 \\
\hline & & & Max & $1,240,400$ & 1,700 & 1,055 \\
\hline \multirow{3}{*}{$\mathrm{T} 3-1 \mathrm{~b}$} & \multirow{3}{*}{$\mathrm{Na}_{7} \mathrm{~F}\left(\mathrm{PO}_{4}\right)_{2} \cdot 19 \mathrm{H}_{2} \mathrm{O}$} & \multirow{3}{*}{3} & Mean & 293,314 & 652 & 457 \\
\hline & & & Min & 4,134 & 98 & 60 \\
\hline & & & Max & 618,588 & 984 & 818 \\
\hline \multirow{3}{*}{$\mathrm{T} 3-1 \mathrm{c}$} & \multirow{3}{*}{$\mathrm{Na}_{7} \mathrm{~F}\left(\mathrm{PO}_{4}\right)_{2} \cdot 19 \mathrm{H}_{2} \mathrm{O}$} & \multirow{3}{*}{14} & Mean & 546,288 & 1,052 & 712 \\
\hline & & & Min & 32,220 & 279 & 174 \\
\hline & & & Max & $1,876,168$ & 2,610 & 1,385 \\
\hline \multirow{3}{*}{ T3-3 } & \multirow{3}{*}{$\mathrm{Na}_{7} \mathrm{~F}\left(\mathrm{PO}_{4}\right)_{2} \cdot 19 \mathrm{H}_{2} \mathrm{O}$} & \multirow{3}{*}{38} & Mean & 96,352 & 301 & 227 \\
\hline & & & Min & 315 & 19 & 19 \\
\hline & & & Max & 830,846 & 1,429 & 1,038 \\
\hline \multirow{3}{*}{ T3-4 } & \multirow{3}{*}{$\mathrm{Na}_{3} \mathrm{PO}_{4} \cdot 12 \mathrm{H}_{2} \mathrm{O}$} & \multirow{3}{*}{75} & Mean & 18,410 & 606 & 35 \\
\hline & & & Min & 2,175 & 108 & 16 \\
\hline & & & Max & 69,947 & 2,486 & 76 \\
\hline \multirow{3}{*}{ T3-5 } & \multirow{3}{*}{$\mathrm{Na}_{7} \mathrm{~F}\left(\mathrm{PO}_{4}\right)_{2} \cdot 19 \mathrm{H}_{2} \mathrm{O}$} & \multirow{3}{*}{42} & Mean & 87,513 & 279 & 211 \\
\hline & & & Min & 654 & 29 & 29 \\
\hline & & & Max & 819,871 & 1,421 & 1,044 \\
\hline
\end{tabular}




\subsection{Dilution Required to Redissolve the Precipitate}

The objective of these tests was to determine the potential to redissolve the post-filtration precipitate observed in PEP Integrated Tests A, B, and D through dilution with DIW at $25 \pm 1{ }^{\circ} \mathrm{C}$. These tests were specified in Test Exception WTP-TEF-RT-09-0001, Rev 1, Task 4 associated with Test Plan TP-WTP-PEP-044, Rev 0.2.

Two samples from the PEP Integrated Test A (2367-wash 30 and 2587-wash 70), two samples from the PEP Integrated Test B (4232 - wash 10 and 4267-wash 45), and three samples from the PEP Integrated Test D (5652--post-caustic-leach, 5457-wash 21, and 5478-wash 42) were used for this task. These tests were performed in duplicate by placing $100-\mathrm{mL}$ of these test samples into $200-\mathrm{mL}$ centrifuge tubes and holding them at $25^{\circ} \mathrm{C}$ for 48 hours while shaking at $150 \mathrm{rpm}$. After 48 hours, they were centrifuged, the volume of solids was measured, and then 5-mL of DIW was added to them. They were well mixed by shaking to resuspend the solids and then held at $25^{\circ} \mathrm{C}$ for 24 hours while shaking at $150 \mathrm{rpm}$ with the process repeated until the solids completely dissolved or the centrifuge tubes became full.

Table 6.1 shows the amount of dilution required for each test to achieve complete solids dissolution or when the centrifuge tube became full. Figure 6.1 shows how the solids decreased with the dilution for each test with $10 \%$ error bars included. After a certain point in several of the samples, the solids dissolved an unobservable amount so that it appeared they were not dissolving. The dilution was stopped after $85-\mathrm{mL}$ of DIW was added because the centrifuge tube was full. However, these results show that the solids are essentially soluble if enough DIW is added. The dried remaining solids weighed 50-mg for Integrated Test D 5652 (post-caustic-leach) and 5-mg for Integrated Test B 4267 (wash 45). 
Table 6.1. Amount DIW Required to Achieve Complete Dissolution of Solids

\begin{tabular}{|c|c|c|c|c|c|}
\hline Test ID & Sample ID & Wash \# & $\begin{array}{l}\text { Sample Amt } \\
(\mathrm{mL})\end{array}$ & $\begin{array}{l}\text { DIW Added } \\
(\mathrm{mL})\end{array}$ & Comments \\
\hline T4-A-2367a & Test A 2367 & 30 & 105 & 30 & $\begin{array}{l}\text { No solids at this } \\
\text { point }\end{array}$ \\
\hline T4-A-2367b & Test A 2367 & 30 & 110 & 30 & $\begin{array}{l}\text { No solids at this } \\
\text { point }\end{array}$ \\
\hline T4-A-2587a & Test A 2587 & 70 & 105 & 30 & $\begin{array}{l}\text { No solids at this } \\
\text { point }\end{array}$ \\
\hline T4-A-2587b & Test A 2587 & 70 & 105 & 30 & $\begin{array}{l}\text { No solids at this } \\
\text { point }\end{array}$ \\
\hline T4-B-4232a & Test B 4232 & 10 & 100 & 30 & $\begin{array}{l}\text { No solids at this } \\
\text { point }\end{array}$ \\
\hline T4-B-4232b & Test B 4232 & 10 & 105 & 30 & $\begin{array}{l}\text { No solids at this } \\
\text { point }\end{array}$ \\
\hline T4-B-4267a & Test B 4267 & 45 & 110 & 85 & $\begin{array}{l}\text { Stopped with skiff } \\
\text { of solids left }\end{array}$ \\
\hline T4-B-4267b & Test B 4267 & 45 & 113 & 85 & $\begin{array}{l}\text { Stopped with skiff } \\
\text { of solids left }\end{array}$ \\
\hline T4-D-5652a & Test D 5652 & $\begin{array}{c}\text { Post-caustic- } \\
\text { leach }\end{array}$ & 98 & 85 & $\begin{array}{l}\text { Stopped with skiff } \\
\text { of solids left }\end{array}$ \\
\hline T4-D-5652b & Test D 5652 & $\begin{array}{c}\text { Post-caustic- } \\
\text { leach }\end{array}$ & 99 & 85 & $\begin{array}{l}\text { Stopped with skiff } \\
\text { of solids left }\end{array}$ \\
\hline T4-D-5457a & Test D 5457 & 21 & 101 & 50 & $\begin{array}{l}\text { No solids at this } \\
\text { point }\end{array}$ \\
\hline T4-D-5457b & Test D 5457 & 21 & 103 & 50 & $\begin{array}{l}\text { No solids at this } \\
\text { point }\end{array}$ \\
\hline T4-D-5478a & Test D 5478 & 42 & 105 & 55 & $\begin{array}{l}\text { No solids at this } \\
\text { point }\end{array}$ \\
\hline T4-D-5478b & Test D 5478 & 42 & 104 & 50 & $\begin{array}{l}\text { No solids at this } \\
\text { point }\end{array}$ \\
\hline
\end{tabular}




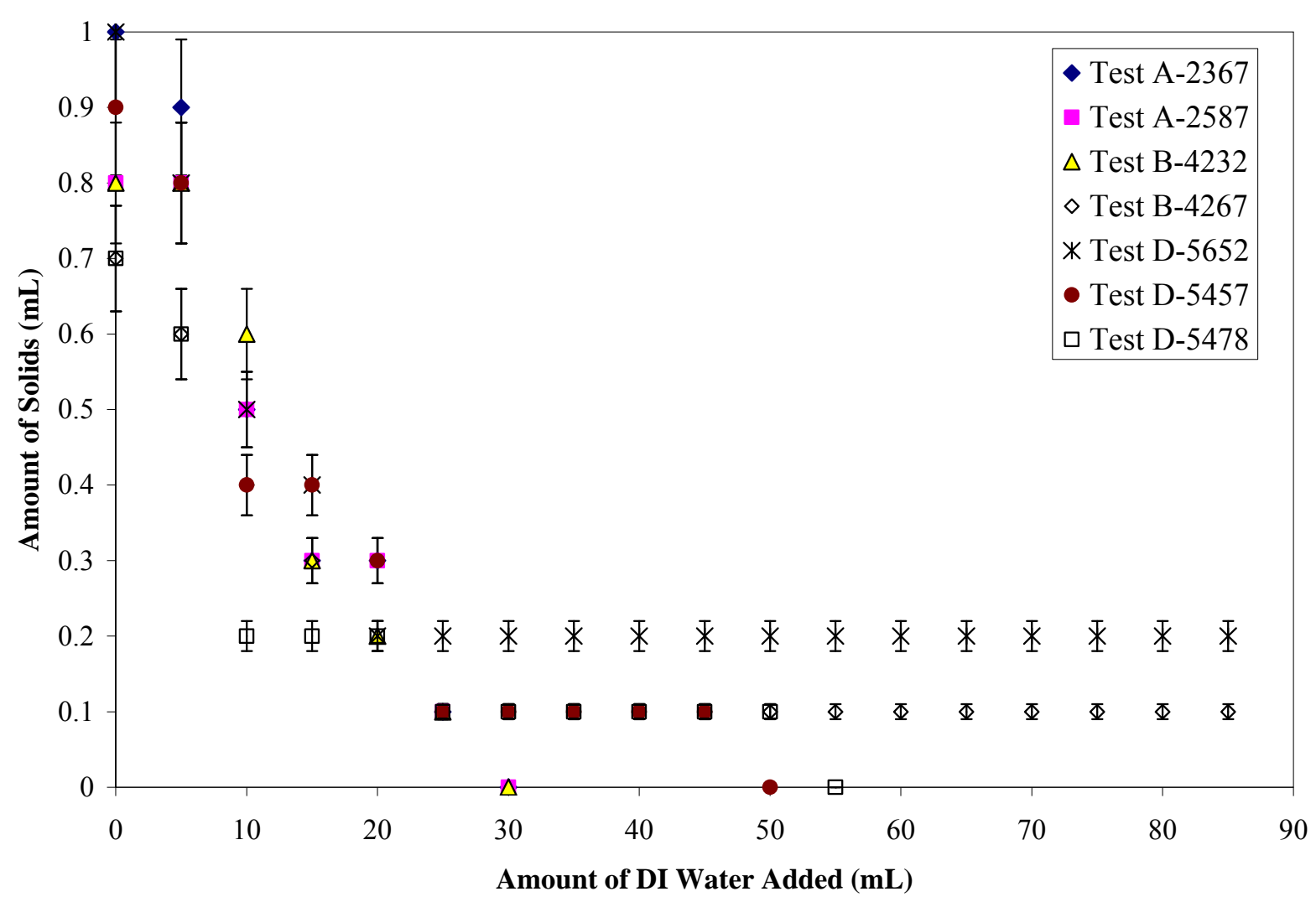

Figure 6.1. Solids Dissolution with DIW Addition 



\subsection{Supersaturation in Post-Caustic-Leach Filtrates from PEP Integrated Test B}

The objective of these tests was to determine the solution supersaturation in the post-caustic-leach filtrate during the dewatering and washing period based on the samples collected during PEP Integrated Test B. These tests were specified in Test Exception WTP-TEF-RT-09-0001, Rev 1, Task 5 associated with Test Plan TP-WTP-PEP-044, Rev 0.2.

The concentrated caustic-leached solids in UFP-VSL-T02A were washed incrementally with $0.01 \mathrm{M} \mathrm{NaOH}$ in the PEP Integrated Test $\mathrm{B}$. The wash liquid was added in steps with 11 gallon target volume for each step and 52 steps total. Samples were taken in 1-L sample bottles. Each 1-L sample number represented a wash step with a total of 52 samples taken. During every third or fourth wash step, AFA was added to maintain a target concentration of $350 \mathrm{ppm}$. Wash liquid additions were initiated when the level in the vessel UFP-VSL-T02A dropped below a set value, occurring approximately every 4 minutes. Permeate was continuously removed at a rate between $1-\mathrm{kg} / \mathrm{min}$ and $8-\mathrm{kg} / \mathrm{min}$ by ultrafiltration through all five filter bundles.

The caustic-leach wash samples were collected from March 19, 2009, 16:27 until March 20, 2009, 1:03. All 52 samples were stored at ambient temperature of the PDL-W facility and were then transferred to the APEL laboratory on March 20, 2009.

These supernate and wash samples from the post-caustic-leach slurry concentration period were processed as follows:

- All 52 samples were stored at room temperature $\left(\sim 18\right.$ to $\left.22^{\circ} \mathrm{C}\right)$ in the APEL laboratory for 94 days.

- A subset of samples (4153, 4154, 4223, 4225, 4227, 4229, 4231, 4234, 4237, and 4240) was held at $20^{\circ} \mathrm{C}$ for 72 hours and then sampled for characterization of the solution phase by ICP and IC analysis.

- The temperature of this subset of samples was raised incrementally by $1{ }^{\circ} \mathrm{C}$ and held there for 24 hours until $30^{\circ} \mathrm{C}$ was reached. The solution phase of the subset was sampled after 24 hours at $25^{\circ} \mathrm{C}$ for chemical characterization by ICP and IC analyses.

- The temperature was then raised from $30^{\circ} \mathrm{C}$ to $35^{\circ} \mathrm{C}$ in a single increment and the samples held at $35^{\circ} \mathrm{C}$. Again, the solution phase of the subset was sampled for chemical characterization after 24 hours at $35^{\circ} \mathrm{C}$ by ICP and IC analyses.

Samples 4153 (caustic leachate), 4154 (caustic leachate), 4223 (wash 1), 4225 (wash 3), 4227 (wash 5), 4229 (wash 7), 4231 (wash 9), 4234 (wash 12), 4237 (wash 15), and 4240 (wash 18) were tested by placing them in an incubator at $20^{\circ} \mathrm{C}$ for 72 hours while shaking at $150 \mathrm{rpm}$. After 72 hours at $20^{\circ} \mathrm{C}$, supernate samples were taken by placing approximately $1.5-\mathrm{mL}$ of supernate (filtered through a $0.45-\mu \mathrm{m}$ filter immediately) into a sample bottle containing approximately $15-\mathrm{mL}$ of DIW to dilute it approximately 10 times.

The temperature was then increased $1{ }^{\circ} \mathrm{C}$ every 24 hours and the samples allowed to equilibrate for 24 hours. After each 24-hour period, the samples were inspected for remaining solids. This continued until the temperature reached $30^{\circ} \mathrm{C}$. After the samples reached $30^{\circ} \mathrm{C}$, solids still remained in the majority of the samples. Therefore, the temperature was increased to $35^{\circ} \mathrm{C}$, and the samples were allowed to 
equilibrate for 24 hours at $35^{\circ} \mathrm{C}$. Supernate samples were taken at $25^{\circ} \mathrm{C}$ and at $35^{\circ} \mathrm{C}$ by placing approximately $1.5-\mathrm{mL}$ of supernate (filtered through a $0.45-\mu \mathrm{m}$ filter immediately) into a sample bottle containing approximately $15-\mathrm{mL}$ of DIW to dilute it approximately 10 times.

The supernate samples were analyzed by ICP for Al, Na, P, and S (shown in Appendix A Table A.5), IC for oxalate, phosphate, sulfate, nitrate, and nitrite (shown in Appendix A Table A.6) to determine the solution saturation compositions and solution density (shown in Appendix A Table A.7).

The results of the oxalate dissolution for these samples are shown in Figure 7.1 with wash numbers increasing from right to left in the figure. Figure 7.1 shows that there was little to no dissolution of oxalate after heating the solutions from $20^{\circ} \mathrm{C}$ to $35^{\circ} \mathrm{C}$ except for washes 15 (sample 4237) and 18 (sample 4240) (the two on the far left of the figure) where an increase occurs from $25^{\circ} \mathrm{C}$ to $35^{\circ} \mathrm{C}$. This is because of the lower solubility of oxalate at high sodium ion concentrations in the earlier wash solutions. The tests show a low sensitivity of sodium oxalate solubility to temperature at high sodium concentrations in solution. However, in washes 15 and 18, the concentration of sodium ion was low enough for oxalate to dissolve. Therefore, when the temperature was increased, the amount of oxalate in the supernate increased in these samples.

The results of the phosphorus (phosphate) dissolution for these samples are shown in Figure 7.2 with wash numbers increasing from right to left in the figure. It can be seen in Figure 7.2 that the phosphorus (phosphate) concentration in solution increased significantly upon heating to $35^{\circ} \mathrm{C}$ for most of the samples with the exception of washes 12 (sample 4234), 15 (sample 4237), and 18 (sample 4240) (the three on the far left of the figure). This can be explained by the fact that by this point, all of the phosphorus (phosphate) had been dissolved and washed out, and therefore, there was no more to dissolve when the temperature was increased in these tests.

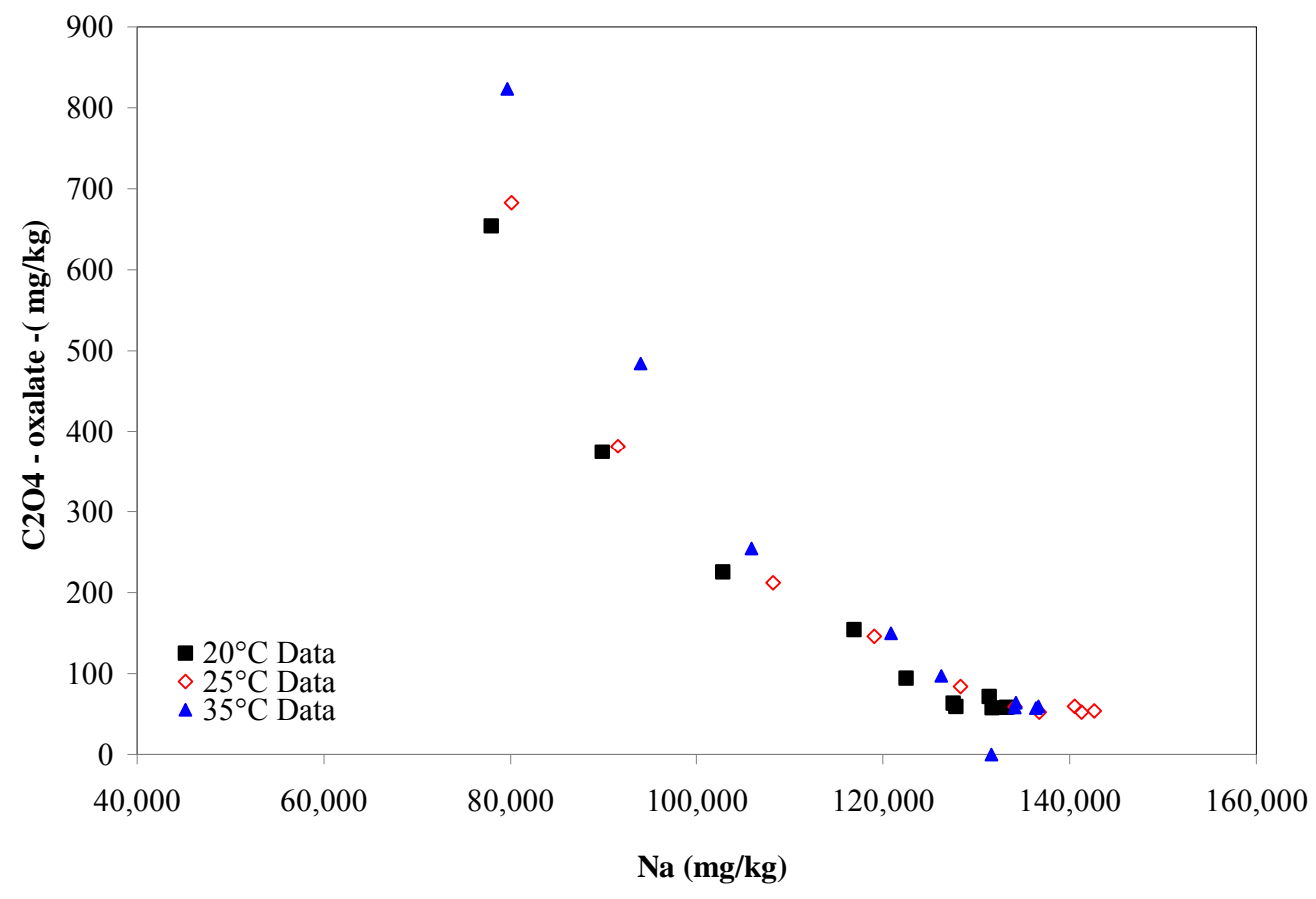

Figure 7.1. Oxalate Concentration Relative to Na During PEP Integrated Test B Washes 


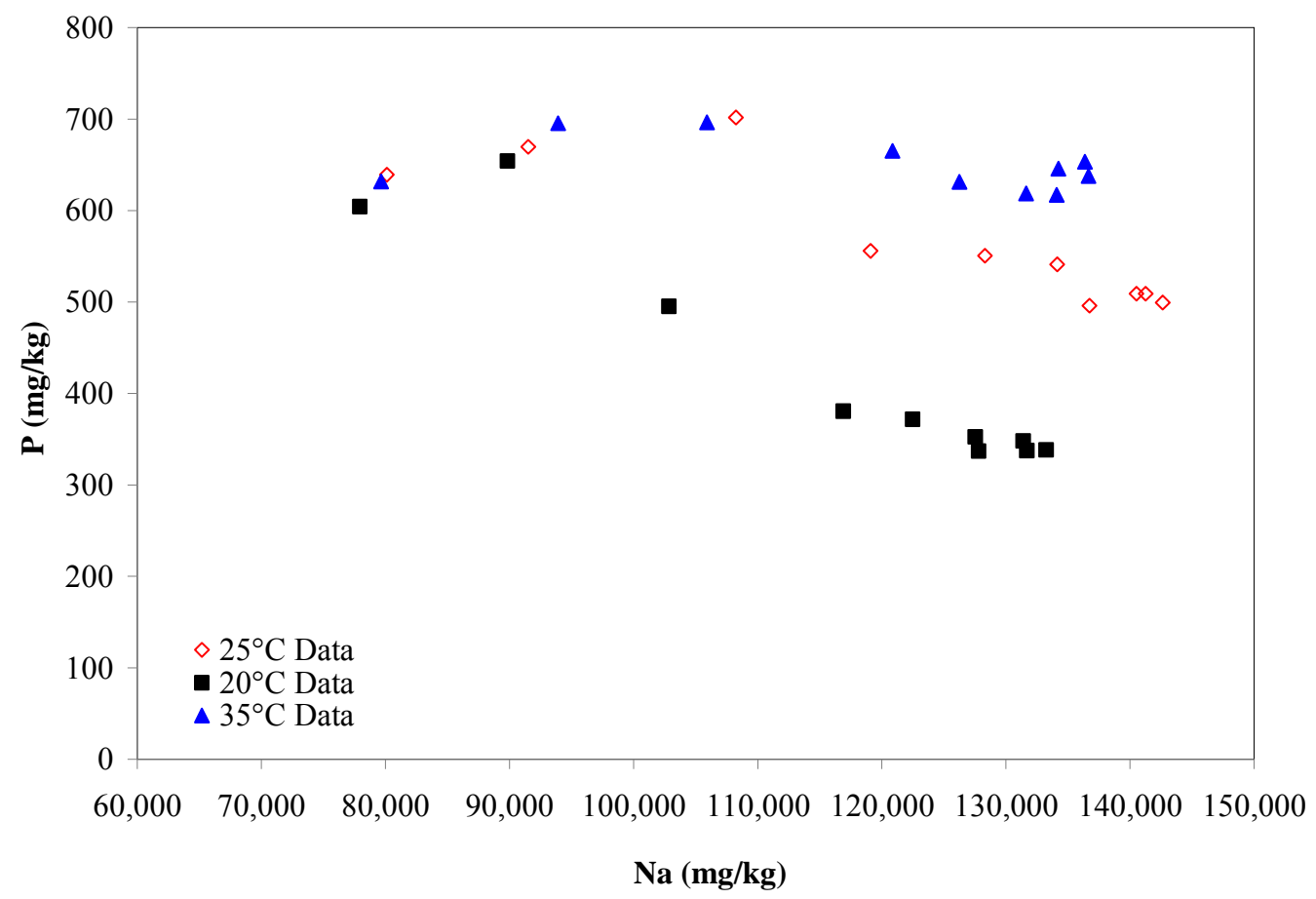

Figure 7.2. Phosphorus Concentration Relative to Na During PEP Integrated Test B Washes

At the end of the test, the supernate was filtered rapidly at $35^{\circ} \mathrm{C}$ using $0.45-\mu \mathrm{m}$ filters to determine how many solids were left in each test bottle. These solids were air-dried and then weighed, and the results are shown in Table 7.1. Figure 7.3 shows the photos of the filtered solids. Each sample contained brownish solids on the filter, and some of them had crystals also.

Table 7.1. Solids Left in Samples after Test Completed

\begin{tabular}{ccc|ccc}
\hline Sample ID & Description & $\begin{array}{c}\text { Solids } \\
\text { Left (g) }\end{array}$ & $\begin{array}{c}\text { Sample } \\
\text { ID }\end{array}$ & Description & $\begin{array}{c}\text { Solids } \\
\text { Left (g) }\end{array}$ \\
\hline 4153 & leachate & 0.1591 & 4229 & Wash 7 & 0.1608 \\
4154 & leachate & 0.1350 & 4231 & Wash 9 & 0.1532 \\
4223 & Wash 1 & 0.2116 & 4234 & Wash 12 & 0.2535 \\
4225 & Wash 3 & 0.1094 & 4237 & Wash 15 & 0.3445 \\
4227 & Wash 5 & 0.1098 & 4240 & Wash 18 & 0.5374 \\
\hline
\end{tabular}




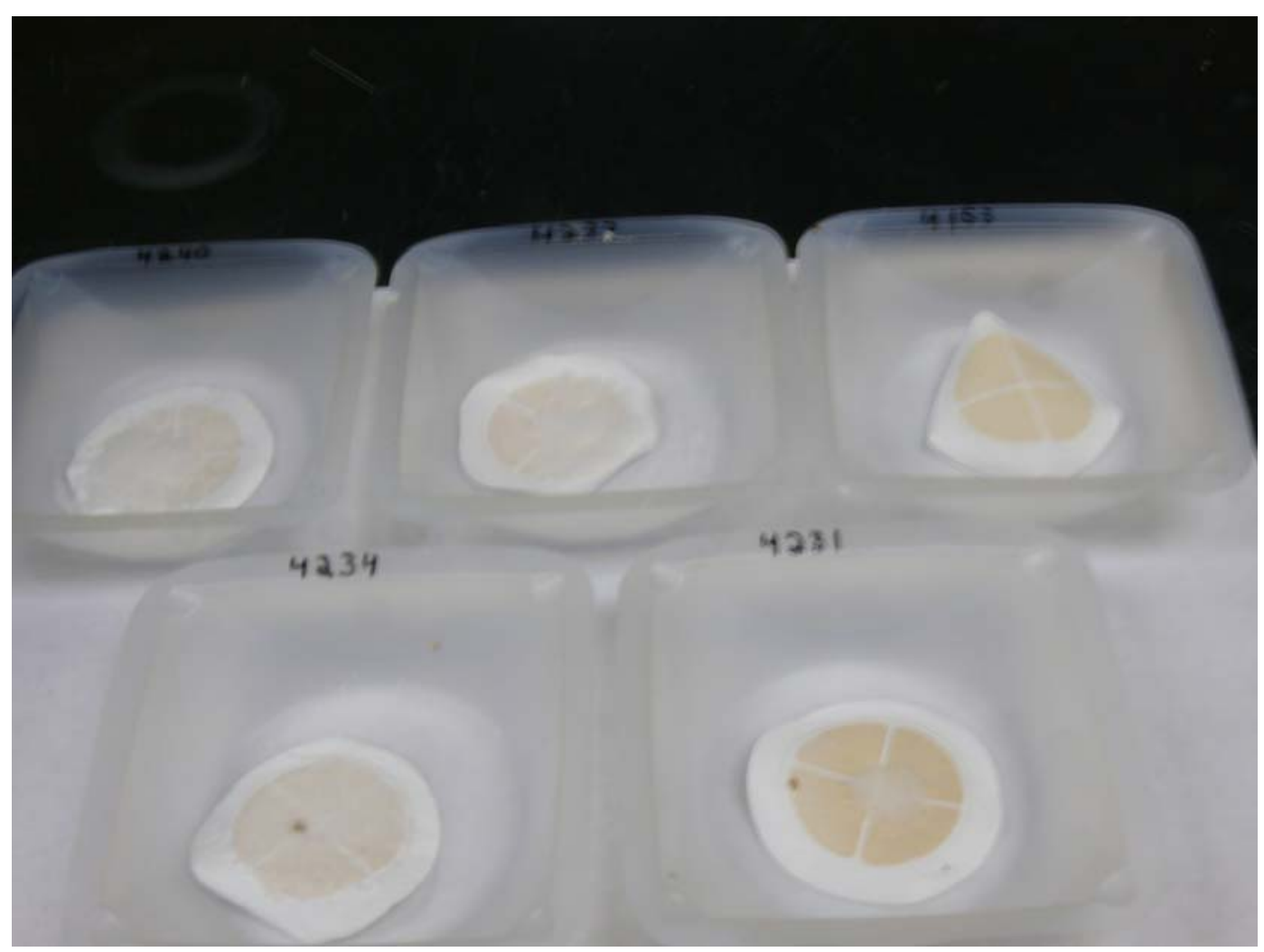

Figure 7.3. Solid Crystals Remaining After Temperature Increased to $35^{\circ} \mathrm{C}$

These crystals were then analyzed by a scanning electron microscope (SEM) equipped with an energy dispersive spectrometer (EDS) by fixing the crystals onto carbon sticky tape and coating the crystals with a conductive coating of $\mathrm{Pd}$ using a sputter coater to determine their composition. Note that EDS-measured compositions are limited to elements with a mass equal to or greater than carbon.

The morphology of sample 4231 is fibrous and fans out at the tips of the crystals, as shown in Figure 7.4 and Figure 7.5. The crystals also tend to form another crystal $90^{\circ}$ from the long axis. EDS analysis of the crystals reveals a chemistry of mainly $\mathrm{Na}, \mathrm{O}$, and $\mathrm{C}$, with minor amounts of $\mathrm{Al}, \mathrm{S}$, and $\mathrm{Cu}$, as given in Table 7.2. Samples 4234, 4237, and 4240 were all similar in chemical composition to sample \#4231. The micrographs of samples 4234, 4237, and 4240, shown in Figure 7.6 through Figure 7.10, are similar to one another, but the tips of the crystals did not fan out as distinctly as those observed in sample 4231. Samples 4231 through 4240 all appear to be $\mathrm{Na}_{2} \mathrm{C}_{2} \mathrm{O}_{4}$, based on the thin needle crystals and measured chemistry.

Sample 4153 is quite different from the other samples in terms of morphology and chemistry. The morphology of the crystals is wide large crystals that appear to have cracked significantly, presumably upon drying, as shown in Figure 7.11. The measured chemistry of sample 4153 is mainly $\mathrm{Na}, \mathrm{P}$, and $\mathrm{O}$, with minor amounts of $\mathrm{Al}, \mathrm{C}, \mathrm{Cu}$, and $\mathrm{S}$, as given in Table 7.2. Sample 4153 appears to be $\mathrm{Na}_{3} \mathrm{PO}_{4} \cdot 12 \mathrm{H}_{2} \mathrm{O}$, based on the measured chemistry and the large needle-shaped crystals. 
Table 7.2. Measured Compositions of Task 5 Dried Crystals

\begin{tabular}{|c|c|c|c|c|c|c|c|c|c|c|}
\hline \multicolumn{11}{|c|}{ Weight $\%$ by Element } \\
\hline Sample \# & Filename & $\mathrm{C}$ & $\mathrm{O}$ & $\mathrm{Na}$ & $\mathrm{Al}$ & $\mathrm{Sr}$ & $\mathrm{P}$ & $\mathrm{S}$ & $\mathrm{Cu}$ & Total \\
\hline 4231 & Area 1.spc & 13.68 & 34.06 & 47.17 & 2.06 & 0.00 & 0.00 & 1.19 & 1.84 & 100.00 \\
\hline 4234 & Area 2.spc & 14.76 & 34.82 & 48.98 & 0.77 & 0.00 & 0.00 & 0.19 & 0.48 & 100.00 \\
\hline 4237 & Area 3.spc & 5.79 & 34.72 & 58.43 & 0.48 & 0.00 & 0.00 & 0.08 & 0.5 & 100.00 \\
\hline 4237 & Area 4.spc & 15.6 & 33 & 47.45 & 2.37 & 0.00 & 0.00 & 0.41 & 1.17 & 100.00 \\
\hline 4240 & Area 5.spc & 6.19 & 30.33 & 61.01 & 0.93 & 0.00 & 0.00 & 0.23 & 1.31 & 100.00 \\
\hline 4153 & Area $6 . s p c$ & 2.4 & 23.46 & 30.1 & 7.28 & 2.91 & 31.7 & 0.8 & 1.36 & 100.01 \\
\hline \multicolumn{11}{|c|}{ Atomic $\%$ by Element } \\
\hline Sample \# & Filename & $\mathrm{C}$ & $\mathrm{O}$ & $\mathrm{Na}$ & $\mathrm{Al}$ & $\mathrm{Sr}$ & $\mathrm{P}$ & $\mathrm{S}$ & $\mathrm{Cu}$ & Total \\
\hline 4231 & Area 1.spc & 20.85 & 38.98 & 37.56 & 1.40 & 0.00 & 0.00 & 0.68 & 0.53 & 100.00 \\
\hline 4234 & Area 2.spc & 22.03 & 39.03 & 38.19 & 0.51 & 0.00 & 0.00 & 0.10 & 0.14 & 100.00 \\
\hline 4237 & Area $3 . s p c$ & 9.24 & 41.56 & 48.66 & 0.34 & 0.00 & 0.00 & 0.05 & 0.15 & 100.00 \\
\hline 4237 & Area 4.spc & 23.43 & 37.21 & 37.21 & 1.59 & 0.00 & 0.00 & 0.23 & 0.33 & 100.00 \\
\hline 4240 & Area 5.spc & 10.05 & 36.98 & 51.76 & 0.67 & 0.00 & 0.00 & 0.14 & 0.4 & 100.00 \\
\hline 4153 & Area $6 . \mathrm{spc}$ & 4.6 & 33.72 & 30.11 & 6.21 & 0.76 & 23.54 & 0.57 & 0.49 & 100.00 \\
\hline
\end{tabular}

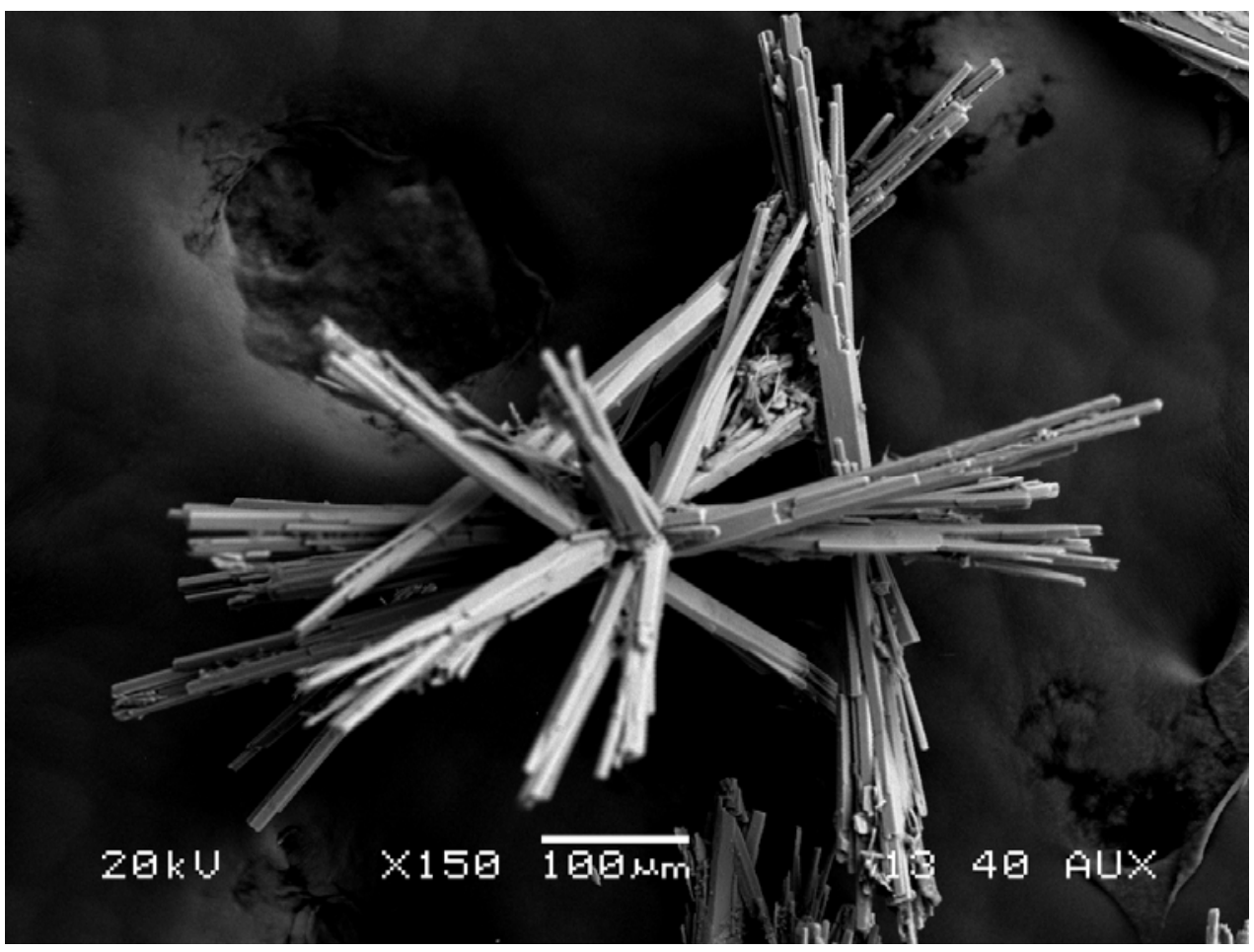

Figure 7.4. SEM Micrograph of Sample 4231 Wash $9\left(\mathrm{Na}_{2} \mathrm{C}_{2} \mathrm{O}_{4}\right)$ 


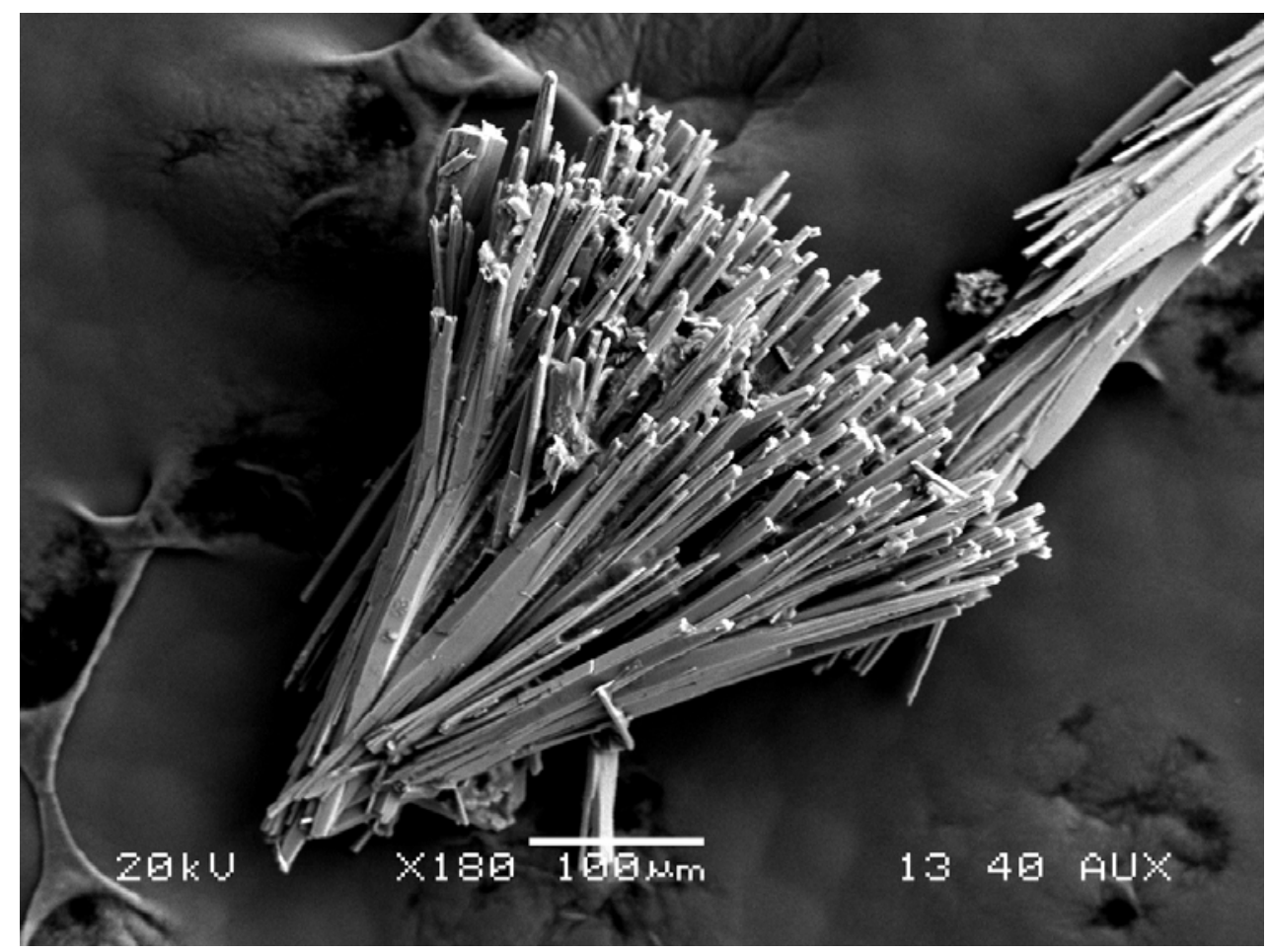

Figure 7.5. SEM Micrograph of Sample 4231 Wash $9\left(\mathrm{Na}_{2} \mathrm{C}_{2} \mathrm{O}_{4}\right)$

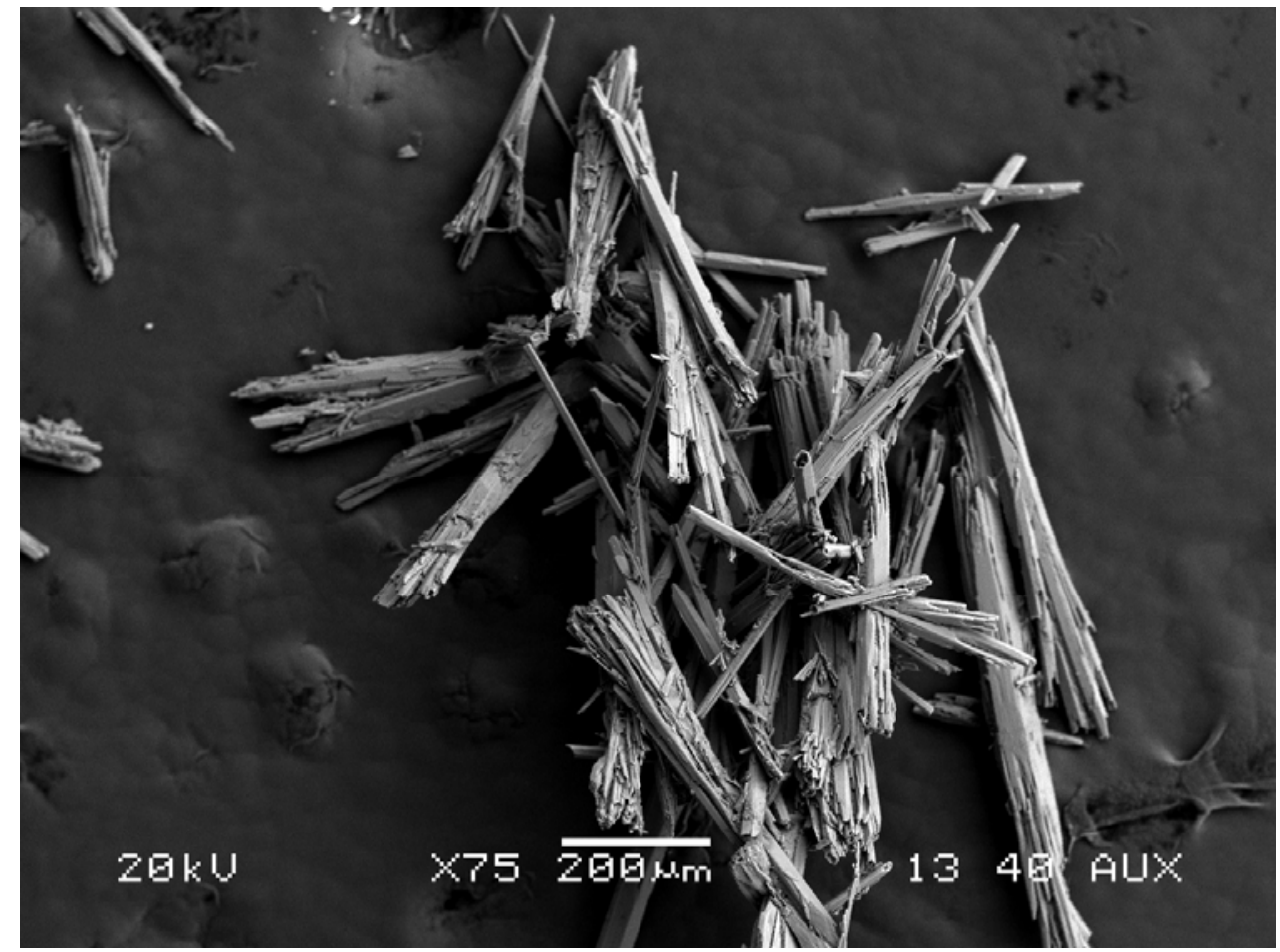

Figure 7.6. SEM Micrograph of Sample 4234 Wash $12\left(\mathrm{Na}_{2} \mathrm{C}_{2} \mathrm{O}_{4}\right)$ 


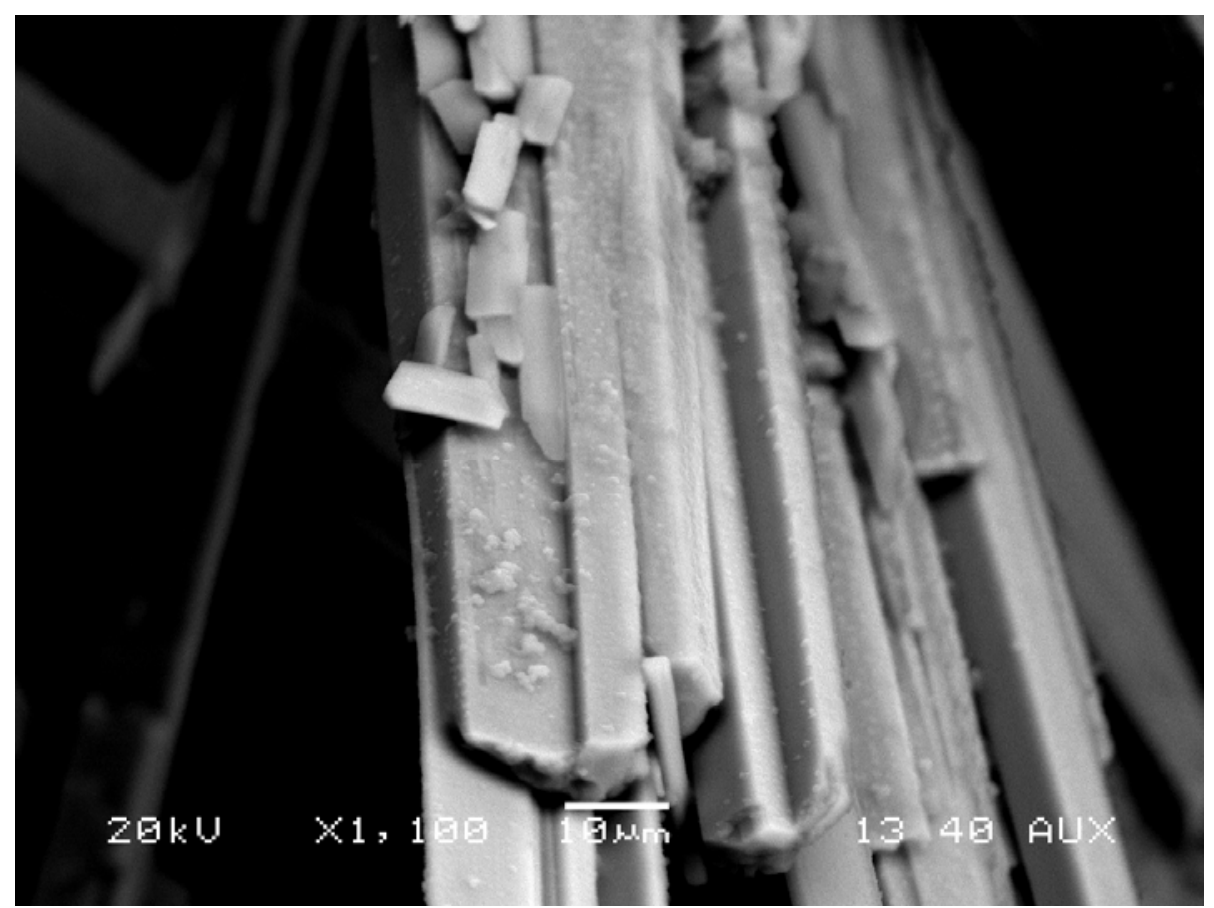

Figure 7.7. SEM Micrograph of Sample 4234 Wash $12\left(\mathrm{Na}_{2} \mathrm{C}_{2} \mathrm{O}_{4}\right)$

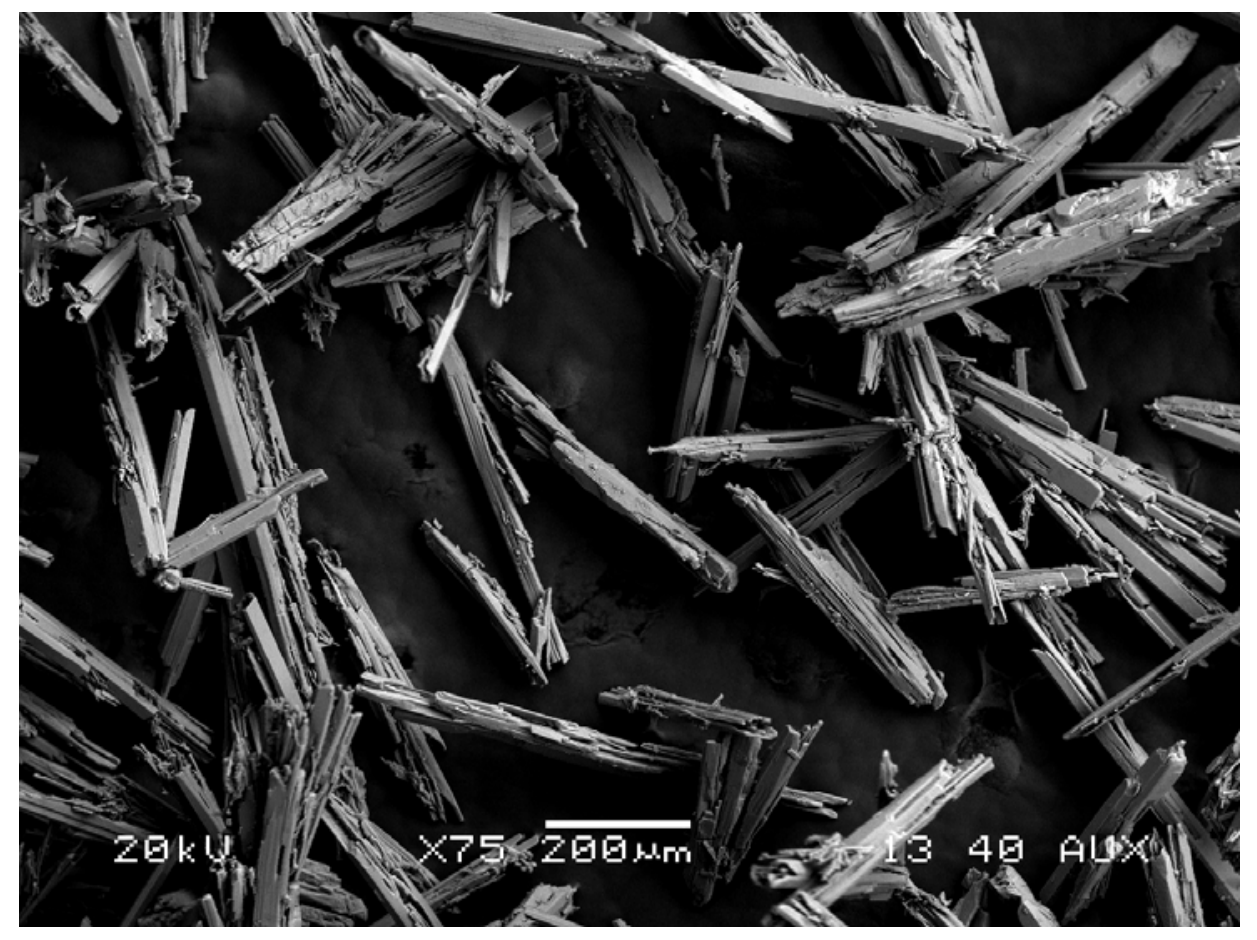

Figure 7.8. SEM Micrograph of Sample 4237 Wash $15\left(\mathrm{Na}_{2} \mathrm{C}_{2} \mathrm{O}_{4}\right)$ 


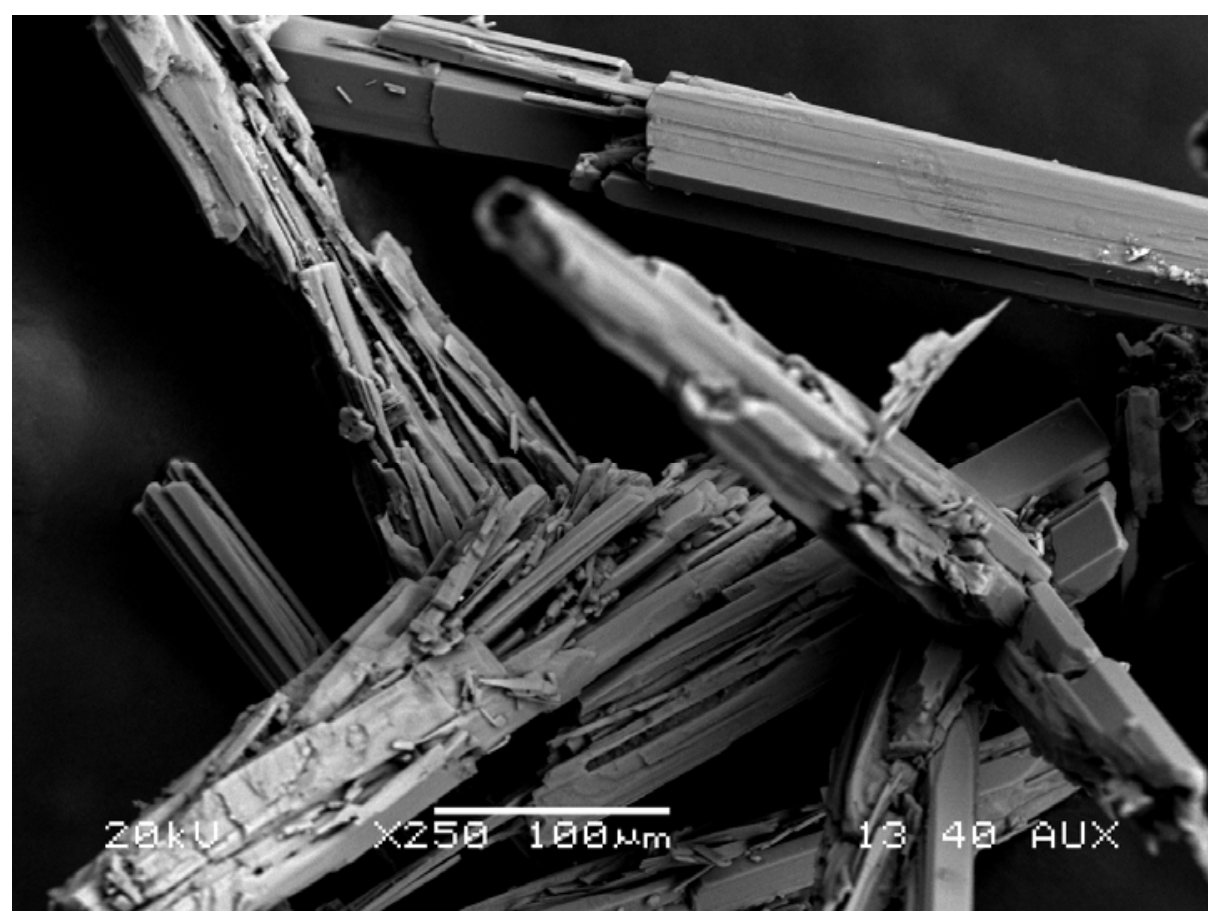

Figure 7.9. SEM Micrograph of Sample 4237 Wash $15\left(\mathrm{Na}_{2} \mathrm{C}_{2} \mathrm{O}_{4}\right)$

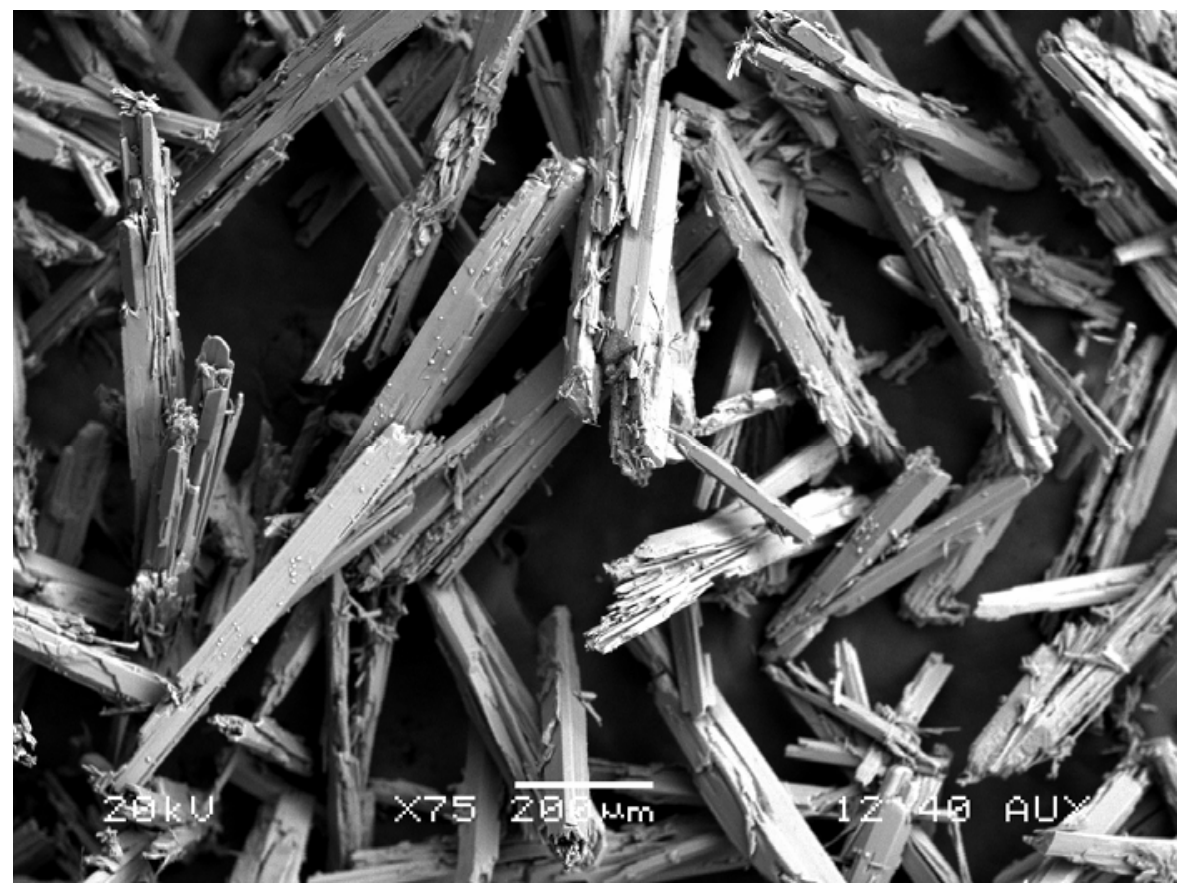

Figure 7.10. SEM Micrograph of Sample 4240 Wash $18\left(\mathrm{Na}_{2} \mathrm{C}_{2} \mathrm{O}_{4}\right)$ 


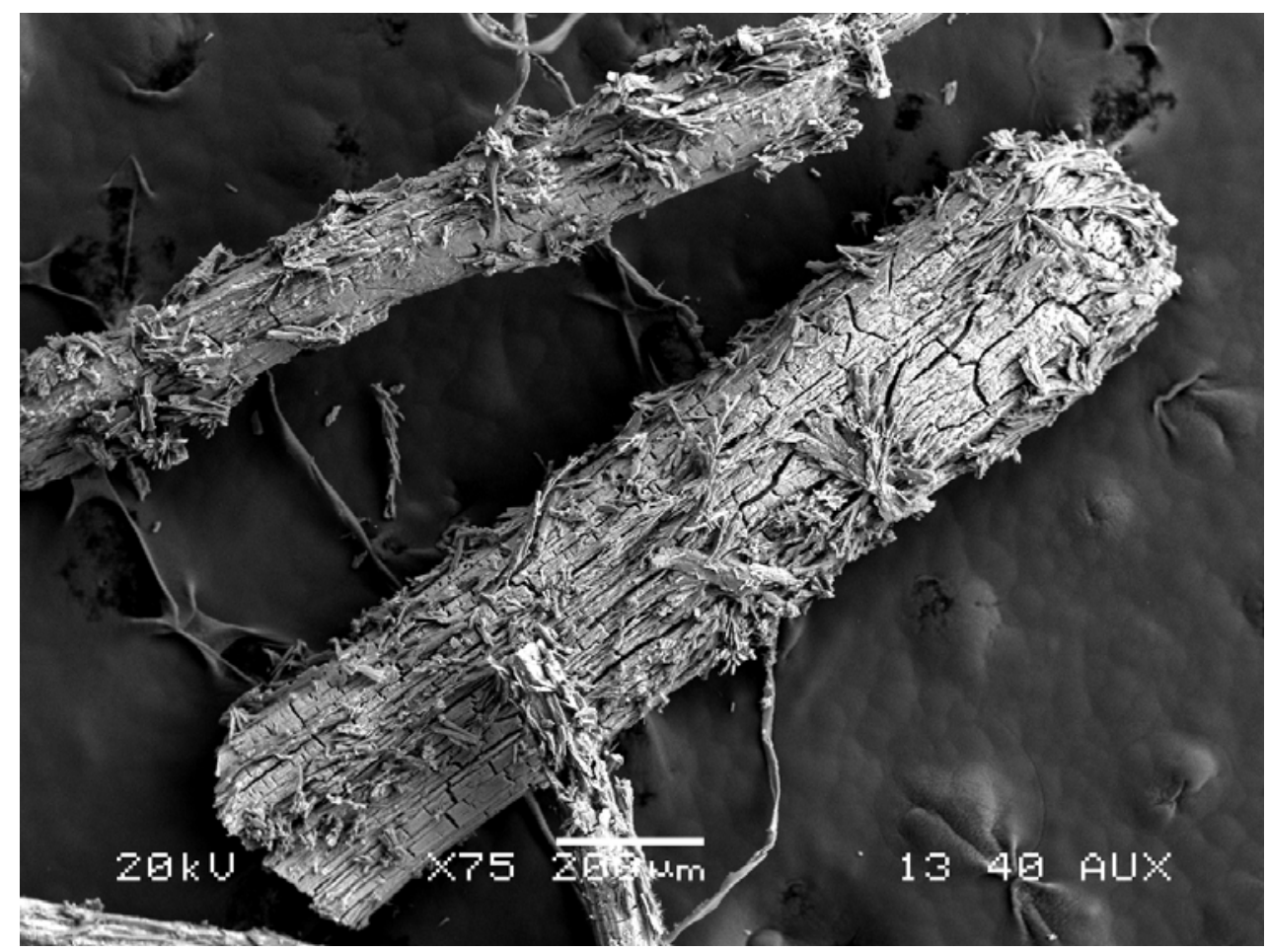

Figure 7.11. SEM Micrograph of Sample 4153 Leachate $\left(\mathrm{Na}_{3} \mathrm{PO}_{4} \cdot 12 \mathrm{H}_{2} \mathrm{O}\right)$ 



\subsection{Effects of Blending During the Post-Caustic-Leach Dewatering and Wash Cycle}

The objective of these tests was to determine the effects of blending permeate, leachate, and wash solution during the post-caustic-leach dewatering and wash periods in the PEP Integrated Test B. These tests were specified in Test Exception WTP-TEF-RT-09-0001, Rev 1, Task 6 associated with Test Plan TP-WTP-PEP-044, Rev 0.2.

Several of the PEP Integrated Test B permeate, leachate, and wash solution samples were blended together in different combinations to determine the effect of these blends on precipitation. Five blends were prepared for this testing as shown in Table 8.1. Blend 1 represented mixing the filtrates from Integrated Test B, Blend 2 represented mixing the leachate and concentrated wash (wash liquids down to $2.6 \mathrm{M} \mathrm{Na}$ ), Blend 3 represented mixing the leachate, concentrated wash (wash liquids down to $2.6 \mathrm{M} \mathrm{Na}$ ), and dilute wash (wash liquids from 2.6 to $0.3 \mathrm{M} \mathrm{Na}$ ), Blend 4 represented mixing the concentrated (wash liquids down to $2.6 \mathrm{M} \mathrm{Na}$ ) and dilute washes (wash liquids from 2.6 to $0.3 \mathrm{M} \mathrm{Na}$ ), and Blend 5 represented mixing concentrated washes (wash liquids down to $2.6 \mathrm{M} \mathrm{Na}$ ) only.

Table 8.1. PEP Integrated Test B Blend Compositions

\begin{tabular}{ccccccc}
\hline PEP ID & Description & $\begin{array}{c}\text { Blend 1 } \\
(\mathrm{mL})\end{array}$ & $\begin{array}{c}\text { Blend 2 } \\
(\mathrm{mL})\end{array}$ & $\begin{array}{c}\text { Blend 3 } \\
(\mathrm{mL})\end{array}$ & $\begin{array}{c}\text { Blend 4 } \\
(\mathrm{mL})\end{array}$ & $\begin{array}{c}\text { Blend 5 } \\
(\mathrm{mL})\end{array}$ \\
\hline 4037 & permeate & 115 & - & - & - & - \\
4153 & leachate & 30 & 125 & 62.5 & - & - \\
4224 & Wash 2 & - & 25 & 12.5 & 15 & 50 \\
4225 & Wash 3 & 7.5 & - & - & - & - \\
4226 & Wash 4 & - & 25 & 12.5 & 15 & 50 \\
4228 & Wash 6 & 7.5 & - & - & - & - \\
4229 & Wash 7 & - & 25 & 12.5 & 15 & 50 \\
4231 & Wash 9 & 7.5 & 25 & 12.5 & 15 & 50 \\
4234 & Wash 12 & 7.5 & 25 & 12.5 & 15 & 50 \\
4237 & Wash 15 & 15 & - & 25 & 35 & - \\
4243 & Wash 21 & 15 & - & 25 & 35 & - \\
4250 & Wash 28 & 15 & - & 25 & 35 & - \\
4256 & Wash 34 & 15 & - & 25 & 35 & - \\
4261 & Wash 39 & 15 & - & 25 & 35 & - \\
\hline
\end{tabular}

The solutions were mixed together in a $500-\mathrm{mL}$ bottle and then placed in an incubator for 48 hours at $25 \pm 1^{\circ} \mathrm{C}$ shaking at $150 \mathrm{rpm}$. Blends 1,3 , and 4 became cloudy when the solutions were added, indicating precipitate forming at time zero. Blends 2 and 5 remained clear throughout the addition of solutions. After 9 days, Blend 2 also contained slight visible precipitate. These blends were then filtered at the end of the test using $0.45-\mu \mathrm{m}$ filters to determine how many solids were formed in each blend. These solids were air-dried and then weighed, and the results are shown in Table 8.2. The final composition of the 
blend supernates was also analyzed by ICP and IC and is shown in Appendix A, Table A.8 and Table A.9, respectively. Note that Blends 1,3, and 4 all contained a mix of leachate and later washes. These later washes would have contained high concentrations of oxalate. Thus, it is likely that the cause of the immediate precipitate in Blends 1, 3 and 4 was sodium oxalate. Blends 2 and 5 did not contain those later washes and as such, did not achieve as great a degree of supersaturation.

Table 8.2. Solids Formed in Blends after Test Completed

\begin{tabular}{cccc}
\hline Sample ID & Total Slurry Wt $(\mathrm{g})$ & Solids Left $(\mathrm{g})$ & $\mathrm{Wt} \%$ Solids \\
\hline Blend 1 & 292.54 & 0.5301 & 0.18 \\
Blend 2 & 307.85 & 0.1525 & 0.05 \\
Blend 3 & 282.33 & 0.8973 & 0.32 \\
Blend 4 & 273.78 & 0.7834 & 0.29 \\
Blend 5 & 304.73 & 0.0937 & 0.03 \\
\hline
\end{tabular}

After sitting at ambient temperature $\left(\sim 18\right.$ to $\left.22^{\circ} \mathrm{C}\right)$ for a couple of weeks, Blend 2 and Blend 5 formed precipitate on the bottom of the bottle as shown in Figure 8.1 and Figure 8.2. This may have been due to the slight drop in temperature, which caused the phosphate to precipitate.

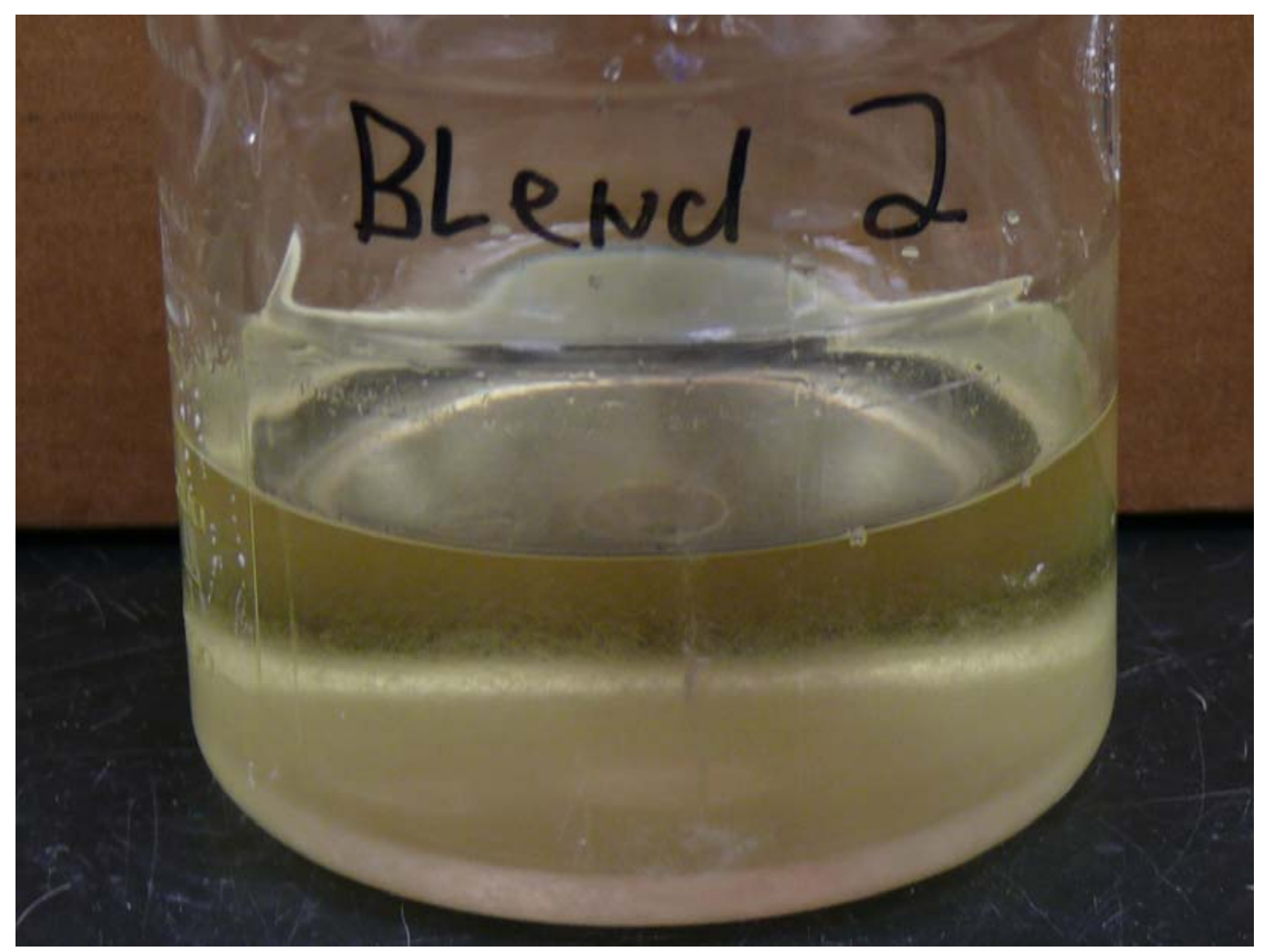

Figure 8.1. Blend 2 Solids Formed after Sitting at Ambient Laboratory Temperature 


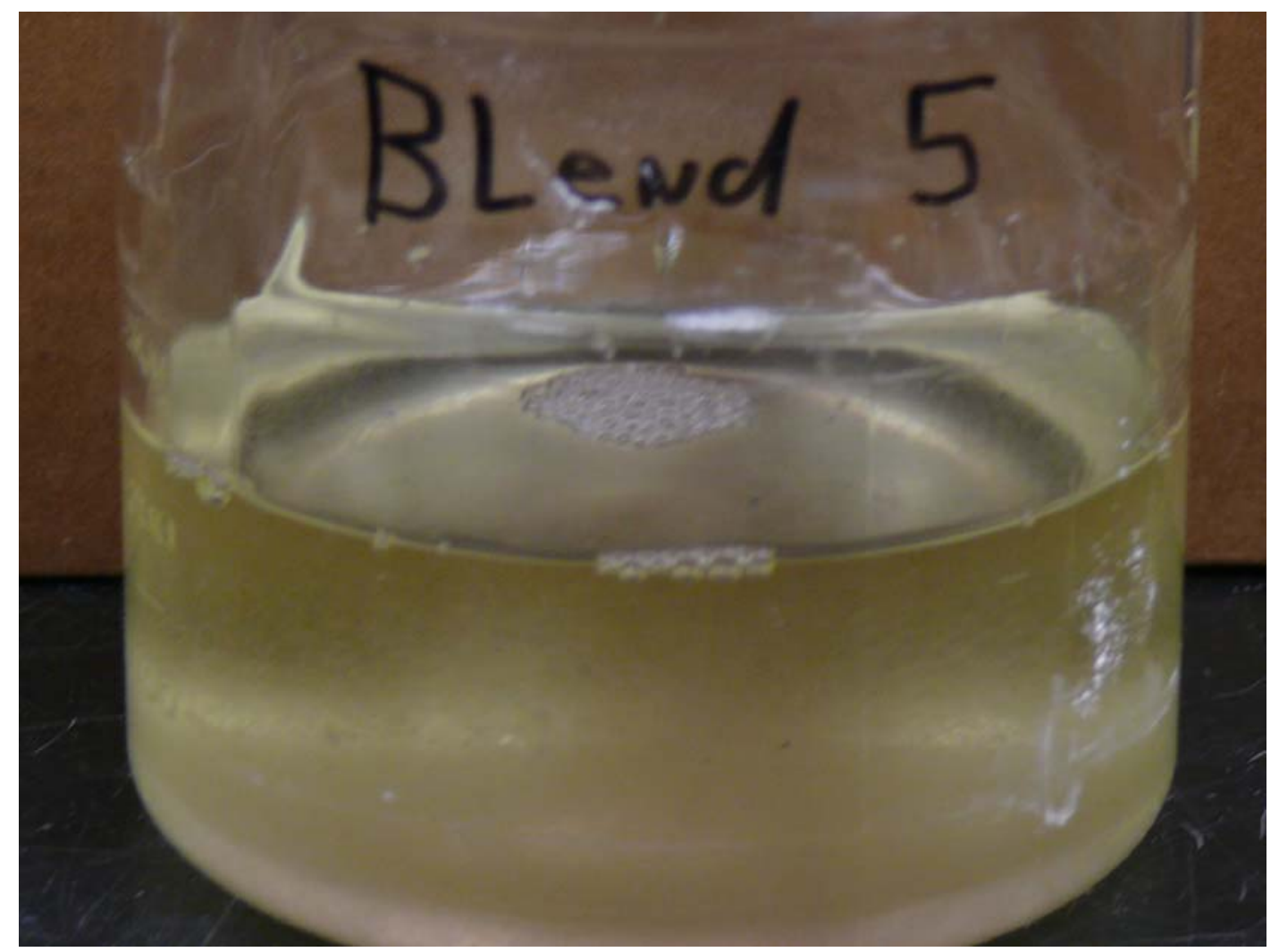

Figure 8.2. Blend 5 Solids Formed after Sitting at Ambient Laboratory Temperature 



\subsection{Summary}

During demonstration of the leaching and ultrafiltration processes in the PEP, significant post-filtration precipitation was observed in the post-caustic leachate and wash solutions. Precipitation in this stream could lead to accumulation of precipitates in filtrate receipt vessels and in the feed to ion exchange columns. Post-filtration precipitation in the feed to the ion-exchange column will have a very significant effect on the operability of the unit and the pretreatment process. This work scope was completed to develop an understanding of the phenomenon of precipitation after filtration. The results of the test objective are documented according to tasks in Sections 3.0 through 8.0. The following is a summary of the preceding sections.

The objective of the Task 1 tests was to determine the post-filtration precipitate mineralogy, precipitate phase compositions, and solution saturation compositions in the post-caustic leachate and wash-solution samples from the PEP Integrated Test A at ambient temperature. These washes all formed precipitate and then were filtered using a $0.45-\mu \mathrm{m}$ filter after 16 days at an ambient temperature of 18 to $22^{\circ} \mathrm{C}$. After drying, the $\mathrm{wt} \%$ undissolved solids ranged from $0.038-\mathrm{wt} \%$ to $0.44-\mathrm{wt} \%$. However, even after filtering, crystals continued to form at ambient temperature $\left(\sim 18\right.$ to $\left.22^{\circ} \mathrm{C}\right)$ in the supernate over the next couple of months.

The analytical results of the solution phase indicate that the sodium oxalate and sodium phosphate dissolved and increased in concentration throughout the washes whereas the other analytes decreased in concentration progressively during the post-caustic-leach wash. This allowed sodium phosphate and sodium oxalate to become supersaturated and precipitate as the temperature dropped over time to form precipitated solids. The oxalates appeared to dissolve in more dilute solution because of the reduced common ion effect of sodium. The phosphate dissolved and appeared earlier as the caustic leached slurry was washed until it was all dissolved.

Pictures were taken of the dried solids from the samples in polarized light, cross-polarized light, and cross-polarized light with a full wave plate. Interference patterns were only obtained for samples 2341 (wash 3), 2349 (wash 11), and 2363 (wash 25) and indicated sodium phosphate based on the crystal shape and color refraction. Sample 2369 (wash 31) indicated sodium oxalate based on the crystal shape. These results are all in agreement with the chemical analysis and XRD. This can be explained by 1) differences in the solubilities of sodium phosphate and sodium oxalate as a function of sodium ion concentrations in solution, and 2) the quantities of precipitated phosphates and oxalates at the end of the caustic leaching operation. Aluminum compounds were not observed to precipitate in these washes.

The objective of the Task 2 tests was to determine the rate at which the anions of interest (phosphate, oxalate, sulfate, silicate, and fluoride) approach equilibrium solution composition in post-caustic-leach slurry at $25^{\circ} \mathrm{C}$ before filtration using controlled laboratory experiments. These tests were performed using simplified simulated post-caustic-leach slurry (derived from the PEP Integrated Test A). The simulated post-caustic-leach slurry was spiked with each target anion (phosphate, oxalate, sulfate, silicate, and fluoride) in the form of a sodium salt.

Eleven different blends of the target anions were prepared and held at $85^{\circ} \mathrm{C}$ for 24 hours and then cooled to $25^{\circ} \mathrm{C}$ and held for 24 hours. The samples were then cooled to $16^{\circ} \mathrm{C}$ and held for 24 hours and 
heated back to $25^{\circ} \mathrm{C}$ and held 96 hours. The solutions were sampled periodically throughout the test and analyzed for the presence of these anions.

All of the samples taken while the supernate temperature was at $85^{\circ} \mathrm{C}$ for 24 hours developed an orange-brown precipitate after being diluted with DIW and sitting at ambient temperature $\left(\sim 18\right.$ to $\left.22^{\circ} \mathrm{C}\right)$ for 26 hours. The Fe-rich slurry is believed to be the source of the brown precipitate since sample T2-9 (null test without any anion spikes) had just as much precipitate as the other samples. Chemical analysis confirmed that it was an iron compound. Iron was present in the post-caustic-leach slurry component.

From these tests, oxalate appears to be fairly slow to precipitate, taking nearly 24 hours before reaching equilibrium. However, the presence of phosphate, sulfate, or fluoride did not significantly change the equilibrium concentration of oxalate, but the kinetics appeared to be faster in the presence of the other anions. In the absence of fluoride, phosphate appears to equilibrate very quickly. However, in the presence of fluoride, phosphate equilibrates much slower and to a significantly lower solubility. Phosphate solubility appears to be a strong function of fluoride. The presence of fluoride does appear to suppress the sulfate solubility. Interestingly, fluoride appears to equilibrate within a few hours.

However, the presence of oxalate appears to suppress the fluoride solubility, but fluoride had no effect on the oxalate solubility.

The objective of the Task 3 tests was to identify precipitates formed at ambient temperature in the presence of phosphate, oxalate, sulfate, silicate, and fluoride anions in the post-caustic leachate solution. Eleven different blends of the target anions were prepared and held at $35^{\circ} \mathrm{C}$ for 24 hours and filtered, and then the supernate was cooled to $20^{\circ} \mathrm{C}$ and held for 96 hours. Five of the 11 tests produced precipitate, which was then analyzed to determine PSD crystal shape and habit (morphology), quantity, and the settling rate of precipitates formed.

The amount of phosphate in solution at $35^{\circ} \mathrm{C}$ appears to be anomalously low. At this point, there is not a good reason why this value was low, but that the sample may not have reached equilibrium at $35^{\circ} \mathrm{C}$. This may be due to either the sample re-equilibrating quickly upon cooling during the separation process or the sample not yet reaching equilibrium during storage at temperature. The amount of phosphate in solution is about $1 / 4$ of the expected amount based on the amount in the test with phosphate only.

Only sodium phosphate and sodium fluoride phosphate exhibit any significant change in solubility with temperature. The other main components appear to be relatively insensitive to temperature.

Task 3 sample solutions containing precipitated crystals were analyzed by OM to gather optical properties of the crystals as well as particle size. All of the Task 3 samples, with the exception of the phosphate only test, contained the same cubic crystal type. These samples were determined to be cubic because of the observed morphology, which is extinct at all angles when under cross-polarized light. These crystals are likely $\mathrm{Na}_{7} \mathrm{~F}\left(\mathrm{PO}_{4}\right)_{2} \cdot 19 \mathrm{H}_{2} \mathrm{O}$ based on the high refractive index of the crystals. The phosphate only test sample contains long, thin, needle-shaped crystals that appear white under cross-polarized light. When a full wave plate is inserted into the cross-polarized light, the crystals appear blue when the long axis of the crystal and the wave plate are parallel and yellowish-orange when perpendicular. Therefore, these crystals are most likely $\mathrm{Na}_{3} \mathrm{PO}_{4} \cdot 12 \mathrm{H}_{2} \mathrm{O}$.

The objective of the Task 4 tests was to determine the potential to redissolve the post-filtration precipitate in Integrated Tests A, B, and D in the PEP through dilution with DIW at $25 \pm 1{ }^{\circ} \mathrm{C}$. DIW was 
added in 5-mL increments every 24 hours until the solids were completely dissolved. These results showed that the solids are essentially soluble if enough DIW is added.

The objective of the Task 5 tests was to determine the solution supersaturation in the post-caustic-leach filtrate during the dewatering and washing period based on the samples collected during the PEP Integrated Test B. Ten post-caustic-leach filtrate and wash solutions from the PEP Integrated Test B were placed in an incubator at $20^{\circ} \mathrm{C}$ for 96 hours. The temperature of the incubator was raised $1{ }^{\circ} \mathrm{C}$ every 24 hours until $30^{\circ} \mathrm{C}$ was reached. The temperature was then raised from $30^{\circ} \mathrm{C}$ to $35^{\circ} \mathrm{C}$ for 24 hours while shaking at $150 \mathrm{rpm}$. Samples were taken at $20^{\circ} \mathrm{C}, 25^{\circ} \mathrm{C}$, and $35^{\circ} \mathrm{C}$.

There was little to no dissolution of oxalate after heating the solutions from $20^{\circ} \mathrm{C}$ to $35^{\circ} \mathrm{C}$, except for wash 15 (sample 4237) and wash 18 (sample 4240) where an increase occurred from $25^{\circ} \mathrm{C}$ to $35^{\circ} \mathrm{C}$. This is because of the lower solubility of oxalate at high sodium ion concentrations in the earlier wash solutions. The tests show a low-sensitivity sodium oxalate solubility to temperature at high sodium concentrations in solution. However, in washes 15 and 18, the concentration of sodium ions was low enough for the precipitated oxalate to dissolve. Therefore, when the temperature was increased, the amount of oxalate in the supernate increased in these samples as the precipitated oxalate dissolved.

The results of the phosphate (phosphorus) dissolution for these samples show that the phosphate (phosphorus) concentration in solution increased significantly upon heating to $35^{\circ} \mathrm{C}$ for most of the samples with the exception of washes 12 (sample 4234), 15 (sample 4237), and 18 (sample 4240). This can be explained by the fact that by this point, all of the phosphorus (phosphate) had dissolved and washed out when the temperature was increased in these tests.

The crystals that did not dissolve were analyzed by SEM equipped with an EDS. Samples 4231 (wash 9) through 4240 (wash 18) all appear to be $\mathrm{Na}_{2} \mathrm{C}_{2} \mathrm{O}_{4}$, based on the thin needle crystals and measured chemistry. Sample 4153(leachate) appears to be $\mathrm{Na}_{3} \mathrm{PO}_{4} \cdot 12 \mathrm{H}_{2} \mathrm{O}$, based on the measured chemistry and the large needle-shaped crystals.

The objective of the Task 6 tests was to determine the effects of blending during the post-caustic-leach dewatering and wash periods in the PEP Integrated Test B. Several of the PEP Integrated Test B permeate, leachate, and wash solution samples were blended together in different combinations to determine the effect of these blends on precipitation. Blend 1 represented mixing the filtrates from Integrated Test B, Blend 2 represented mixing the leachate and concentrated wash (wash liquids down to $2.6 \mathrm{M} \mathrm{Na}$ ), Blend 3 represented mixing the leachate, concentrated wash (wash liquids down to $2.6 \mathrm{M} \mathrm{Na}$ ), and dilute wash (wash liquids from 2.6 to $0.3 \mathrm{M} \mathrm{Na}$ ), Blend 4 represented mixing the concentrated (wash liquids down to $2.6 \mathrm{M} \mathrm{Na}$ ) and dilute washes (wash liquids from 2.6 to $0.3 \mathrm{M} \mathrm{Na}$ ), and Blend 5 represented mixing concentrated washes (wash liquids down to $2.6 \mathrm{M} \mathrm{Na}$ ) only.

The solutions were mixed together in a $500-\mathrm{mL}$ bottle and then placed in an incubator for 48 hours at $25 \pm 1{ }^{\circ} \mathrm{C}$ while shaking at $150 \mathrm{rpm}$. Blends 1,3 , and 4 became cloudy when the solutions were added, indicating precipitate forming at time zero. Blends 2 and 5 remained clear throughout the addition of solutions. After 9 days, Blend 2 also contained slight visible precipitate. These blends were then filtered at the end of the test using $0.45-\mu \mathrm{m}$ filters to determine how many solids were formed in each blend. The $\mathrm{wt} \%$ UDS ranged from $0.03-\mathrm{wt} \%$ in Blend 5 to $0.32-\mathrm{wt} \%$ in Blend 3. Note that Blends 1, 3, and 4 all contained a mix of leachate and later washes. These later washes would have contained high concentrations of oxalate. Thus, it is likely that the cause of the immediate precipitate in Blends 1,3 , and 
4 was sodium oxalate. Blends 2 and 5 did not contain those later washes and as such, did not achieve as great a degree of supersaturation. 


\subsection{Conclusions}

The following conclusions were drawn from this work:

- The analytical results of the PEP Integrated Test A washes from the solution phase indicate that the sodium oxalate and sodium phosphate dissolved and increased in concentration throughout the washes whereas the other analytes decreased in concentration progressively during the post-causticleach wash.

- The oxalates appeared to dissolve in more dilute solution because of the reduced common ion effect of sodium. The phosphate dissolved and appeared earlier as the caustic leached slurry was washed until it was all dissolved.

- Aluminum compounds were not observed to precipitate in these washes.

- Oxalate appears to be fairly slow to precipitate, taking nearly 24 hours before reaching equilibrium. However, the presence of phosphate, sulfate, or fluoride did not significantly change the equilibrium concentration of oxalate, but the kinetics appeared to be faster in the presence of the other anions.

- In the absence of fluoride, phosphate appears to equilibrate very quickly. However, in the presence of fluoride, phosphate equilibrates much slower and to a significantly lower solubility. Phosphate solubility appears to be a strong function of fluoride.

- The presence of fluoride does appear to suppress the sulfate solubility.

- Fluoride appears to equilibrate within a few hours. However, the presence of oxalate appears to suppress the fluoride solubility, but fluoride had no effect on the oxalate solubility.

- Only sodium phosphate and sodium fluoride phosphate exhibit any significant change in solubility with temperature. The other main components appear to be relatively insensitive to temperature.

- All of the Task 3 samples, with the exception of the phosphate-only test, contained the same cubic crystal type, which is most likely $\mathrm{Na}_{7} \mathrm{~F}\left(\mathrm{PO}_{4}\right)_{2} \cdot 19 \mathrm{H}_{2} \mathrm{O}$.

- The precipitated solids are essentially soluble if enough DIW is added.

- Blends containing a mix of leachate and later washes (containing high concentrations of oxalate) precipitated immediately. This is likely due to the high concentration of sodium oxalate present. Blends 2 and 5 did not contain those later washes and as such, did not achieve as great a degree of supersaturation with oxalate. 



\subsection{References}

Barnes SM and R Voke. 2006. "Issue Response Plan for Implementation of External Flowsheet Review Team (EFRT) Recommendations - M12: Undemonstrated Leaching Process." WTP Project Doc. No. 24590-WTP-PL-ENG-06-0024 Rev 0, Bechtel National, Inc., Richland, Washington.

Huckaby JL and JR Markillie. 2008. "Pretreatment Engineering Platform (PEP) Testing (Phase I)." WTP Project Doc. No. 24590-PTF-TSP-RT-07-001, Rev 2, Bechtel National, Inc., Richland, Washington.

Rapko BM, GJ Lumetta, JR Deschane, and RA Peterson. 2007. Process Development for Permanganate Addition During Oxidative Leaching of Hanford Tank Sludge Simulants. WTP-RPT-164, Rev 0. PNNL-16794, Pacific Northwest National Laboratory, Richland, Washington.

Russell RL, RA Peterson, HD Smith, DE Rinehart, PM Aker, and EC Buck. 2009a. Development and Characterization of Boehmite Component Simulant. WTP-RPT-184, Rev 1, PNNL-18176, Pacific Northwest National Laboratory, Richland Washington.

Russell RL, RA Peterson, DE Rinehart, and HD Smith. 2009b. Development and Characterization of Gibbsite Component Simulant. WTP-RPT-176, Rev 0, PNNL-18013, Pacific Northwest National Laboratory, Richland Washington.

Russell RL, JM Billing, RA Peterson, DE Rinehart, and HD Smith. 2009c. Development and Demonstration of Ultrafiltration Simulants. WTP-RPT-183, Rev 0, PNNL-18090, Pacific Northwest National Laboratory, Richland Washington.

Russell, RL, RA Peterson, DE Rinehart, and WC Buchmiller. 2009d. PEP Support: Laboratory Scale Leaching and Permeate Stability Tests. WTP-RPT-200, Rev 0, PNNL-18597, Pacific Northwest National Laboratory, Richland Washington.

Sundar P. 2008. Simulant Recommendation for Phase 1 Testing in the Pretreatment Engineering Platform. WTP Project Doc. No. 24590-PTF-RT-08-006, Rev 0, Bechtel National, Inc., Richland, Washington. 



\section{Appendix A}

Chemical Analysis Results 



\section{Appendix A: Chemical Analysis Results}

Dilution factors were calculated by adding the sample weight and the DIW weight and dividing the sum by the sample weight for all sample results reported from these analytical results.

Table A.1. ICP Results for Task 2 Supernate

\begin{tabular}{|c|c|c|c|c|c|c|c|c|c|c|}
\hline $\begin{array}{c}\text { Test } \\
\text { ID }\end{array}$ & Sample ID & $\begin{array}{c}\text { Sample Wt } \\
\text { (g) }\end{array}$ & DIW (g) & $\begin{array}{c}\mathrm{Al} \\
(\mathrm{mg} / \mathrm{L})\end{array}$ & $\begin{array}{c}\mathrm{Na} \\
(\mathrm{mg} / \mathrm{L})\end{array}$ & $\begin{array}{c}\mathrm{P} \\
(\mathrm{mg} / \mathrm{L})\end{array}$ & $\begin{array}{c}\mathrm{S} \\
(\mathrm{mg} / \mathrm{L})\end{array}$ & $\begin{array}{c}\mathrm{Si} \\
(\mathrm{mg} / \mathrm{L})\end{array}$ & $\begin{array}{c}\mathrm{Fe} \\
(\mathrm{mg} / \mathrm{L})\end{array}$ & $\begin{array}{c}\mathrm{K} \\
(\mathrm{mg} / \mathrm{L})\end{array}$ \\
\hline \multirow{11}{*}{ T2-1a } & $85^{\circ} \mathrm{C}$ & 1.9347 & 14.5796 & 1,140 & 14,400 & 456 & 133 & 1.93 & 2.31 & 86.0 \\
\hline & $25^{\circ} \mathrm{C}-0 \mathrm{hr}$ & 2.0784 & 14.7004 & 1,260 & 15,000 & 52.1 & 135 & 1.60 & 1.66 & 97.4 \\
\hline & $25^{\circ} \mathrm{C}-1 \mathrm{hr}$ & 2.0404 & 14.6059 & 1,240 & 15,200 & 45.2 & 147 & 1.55 & 0.968 & 95.6 \\
\hline & $25^{\circ} \mathrm{C}-2 \mathrm{hr}$ & 1.8480 & 14.6221 & 1,130 & 13,600 & 36.9 & 134 & 1.47 & 0.845 & 88.0 \\
\hline & $25^{\circ} \mathrm{C}-4 \mathrm{hr}$ & 2.9329 & 13.6433 & 1,140 & 14,200 & 32.8 & 139 & 1.49 & 0.900 & 89.8 \\
\hline & $25^{\circ} \mathrm{C}-8 \mathrm{hr}$ & 2.1474 & 14.2005 & 1,360 & 15,700 & 36.9 & 156 & 1.69 & 0.918 & 106 \\
\hline & $25^{\circ} \mathrm{C}-12 \mathrm{hr}$ & 2.2690 & 14.5718 & 1,400 & 15,700 & 36.7 & 169 & 1.78 & 1.14 & 108 \\
\hline & $25^{\circ} \mathrm{C}-24 \mathrm{hr}$ & 2.4826 & 14.5781 & 1,610 & 18,600 & 36.8 & 202 & 2.0 & 1.44 & 117 \\
\hline & $15^{\circ} \mathrm{C}$ & 2.2433 & 14.7031 & 1,410 & 16,900 & 27 & 178 & 2.0 & 1.09 & 103 \\
\hline & $25^{\circ} \mathrm{C}-\mathrm{b} 24 \mathrm{hr}$ & 2.1247 & 14.7548 & 1,330 & 16,100 & 33 & 162 & 1.5 & 0.56 & 98.5 \\
\hline & $25^{\circ} \mathrm{C}-\mathrm{b} 96 \mathrm{hr}$ & 1.9635 & 14.9026 & 1,220 & 14,600 & 32 & 145 & 1.6 & 0.62 & 90.5 \\
\hline \multirow{11}{*}{$\mathrm{T} 2-1 \mathrm{~b}$} & $85^{\circ} \mathrm{C}$ & 1.9840 & 14.6905 & 1,020 & 14,700 & 466 & 139 & 4.43 & 3.23 & 89.1 \\
\hline & $25^{\circ} \mathrm{C}-0 \mathrm{hr}$ & 2.0413 & 14.6731 & 1,060 & 14,900 & 54.1 & 142 & 3.39 & 1.10 & 92.7 \\
\hline & $25^{\circ} \mathrm{C}-1 \mathrm{hr}$ & 2.0380 & 14.6793 & 1,070 & 14,900 & 47.8 & 149 & 3.40 & 1.09 & 94.9 \\
\hline & $25^{\circ} \mathrm{C}-2 \mathrm{hr}$ & 2.1003 & 14.5745 & 1,090 & 15,300 & 44.4 & 152 & 3.52 & 1.11 & 98.5 \\
\hline & $25^{\circ} \mathrm{C}-4 \mathrm{hr}$ & 2.0558 & 14.8148 & 1,040 & 14,700 & 36.5 & 149 & 3.23 & 1.00 & 92.9 \\
\hline & $25^{\circ} \mathrm{C}-8 \mathrm{hr}$ & 2.2809 & 14.2522 & 1,310 & 17,700 & 40.7 & 174 & 3.9 & 2.93 & 109 \\
\hline & $25^{\circ} \mathrm{C}-12 \mathrm{hr}$ & 2.6159 & 14.6052 & 1,450 & 19,300 & 39.0 & 200 & 4.4 & 1.84 & 124 \\
\hline & $25^{\circ} \mathrm{C}-24 \mathrm{hr}$ & 2.4337 & 14.9196 & 1,310 & 17,600 & 37.2 & 189 & 3.9 & 1.51 & 111 \\
\hline & $15^{\circ} \mathrm{C}$ & 2.0434 & 14.7266 & 1,120 & 15,700 & 26 & 169 & 3.2 & 1.16 & 96.2 \\
\hline & $25^{\circ} \mathrm{C}-\mathrm{b} 24 \mathrm{hr}$ & 2.0906 & 14.7012 & 1,130 & 15,800 & 36.7 & 168 & 3.2 & 0.73 & 97.6 \\
\hline & $25^{\circ} \mathrm{C}-\mathrm{b} 96 \mathrm{hr}$ & 1.9644 & 14.8275 & 1,070 & 14,800 & 35.1 & 142 & 2.8 & 0.945 & 91.2 \\
\hline \multirow{11}{*}{$\mathrm{T} 2-1 \mathrm{c}$} & $85^{\circ} \mathrm{C}$ & 1.8050 & 14.5581 & 937 & 13,600 & 426 & 124 & 5.42 & 4.19 & 81.7 \\
\hline & $25^{\circ} \mathrm{C}-0 \mathrm{hr}$ & 1.7735 & 14.7670 & 924 & 12,700 & 43.9 & 120 & 3.17 & 0.932 & 81.1 \\
\hline & $25^{\circ} \mathrm{C}-1 \mathrm{hr}$ & 1.6038 & 14.5611 & 850 & 12,000 & 34.8 & 114 & 2.94 & 0.946 & 75.3 \\
\hline & $25^{\circ} \mathrm{C}-2 \mathrm{hr}$ & 2.0213 & 14.7139 & 1,050 & 14,800 & 38.0 & 142 & 3.48 & 1.47 & 94.6 \\
\hline & $25^{\circ} \mathrm{C}-4 \mathrm{hr}$ & 2.1133 & 14.7556 & 1,070 & 15,100 & 33.2 & 148 & 3.50 & 1.18 & 96.4 \\
\hline & $25^{\circ} \mathrm{C}-8 \mathrm{hr}$ & 1.7146 & 14.3404 & 963 & 12,800 & 27.5 & 123 & 3.16 & 1.19 & 85.2 \\
\hline & $25^{\circ} \mathrm{C}-12 \mathrm{hr}$ & 2.5116 & 14.5171 & 1,400 & 18,600 & 35.3 & 180 & 4.7 & 1.61 & 120 \\
\hline & $25^{\circ} \mathrm{C}-24 \mathrm{hr}$ & 2.0306 & 14.7696 & 1,130 & 15,400 & 32 & 169 & 3.6 & 1.43 & 94.2 \\
\hline & $15^{\circ} \mathrm{C}$ & 2.1823 & 14.4569 & 1,230 & 16,800 & 26 & 167 & 3.7 & 1.22 & 102 \\
\hline & $25^{\circ} \mathrm{C}-\mathrm{b} 24 \mathrm{hr}$ & 2.1155 & 14.5348 & 1,150 & 16,200 & 32 & 151 & 3.5 & 0.868 & 98.1 \\
\hline & $25^{\circ} \mathrm{C}-\mathrm{b} 96 \mathrm{hr}$ & 2.1425 & 14.6962 & 1,150 & 15,900 & 31 & 145 & 3.3 & 1.08 & 99.2 \\
\hline \multirow[t]{10}{*}{$\mathrm{T} 2-2$} & $85^{\circ} \mathrm{C}$ & 1.8534 & 14.6473 & 1,110 & 14,000 & 442 & 339 & 1.88 & 2.78 & 83.4 \\
\hline & $25^{\circ} \mathrm{C}-0 \mathrm{hr}$ & 2.0774 & 14.7051 & 1,180 & 15,400 & 456 & 379 & 1.57 & 1.01 & 89.8 \\
\hline & $25^{\circ} \mathrm{C}-1 \mathrm{hr}$ & 1.8355 & 14.5439 & 1,120 & 13,800 & 61.4 & 364 & 1.36 & 0.549 & 86.9 \\
\hline & $25^{\circ} \mathrm{C}-2 \mathrm{hr}$ & 2.0746 & 14.6716 & 1,230 & 15,200 & 68.9 & 407 & 1.48 & 0.784 & 96.4 \\
\hline & $25^{\circ} \mathrm{C}-4 \mathrm{hr}$ & 1.8476 & 14.6463 & 1,100 & 13,800 & 58.8 & 363 & 1.31 & 0.715 & 86.3 \\
\hline & $25^{\circ} \mathrm{C}-8 \mathrm{hr}$ & 2.1863 & 14.5029 & 1,360 & 16,100 & 72.5 & 428 & 1.57 & 0.806 & 106 \\
\hline & $25^{\circ} \mathrm{C}-12 \mathrm{hr}$ & 2.2154 & 14.2873 & 1,390 & 16,100 & 79.6 & 448 & 1.70 & 0.716 & 107 \\
\hline & $25^{\circ} \mathrm{C}-24 \mathrm{hr}$ & 1.7871 & 14.5852 & 1,190 & 14,000 & 63.3 & 394 & 1.7 & 1.68 & 86.2 \\
\hline & $15^{\circ} \mathrm{C}$ & 2.1842 & 14.2713 & 1,430 & 17,300 & 38.2 & 470 & 1.7 & 0.866 & 106 \\
\hline & $25^{\circ} \mathrm{C}-\mathrm{b} 24 \mathrm{hr}$ & 1.9851 & 14.4748 & 1,230 & 15,500 & 67.3 & 403 & 1.4 & 0.40 & 93.5 \\
\hline
\end{tabular}


Table A.1. ICP Results for Task 2 Supernate

\begin{tabular}{|c|c|c|c|c|c|c|c|c|c|c|}
\hline $\begin{array}{l}\text { Test } \\
\text { ID }\end{array}$ & Sample ID & $\begin{array}{c}\text { Sample Wt } \\
\text { (g) }\end{array}$ & DIW (g) & $\begin{array}{c}\mathrm{Al} \\
(\mathrm{mg} / \mathrm{L})\end{array}$ & $\begin{array}{c}\mathrm{Na} \\
(\mathrm{mg} / \mathrm{L})\end{array}$ & $\begin{array}{c}\mathrm{P} \\
(\mathrm{mg} / \mathrm{L})\end{array}$ & $\begin{array}{c}\mathrm{S} \\
(\mathrm{mg} / \mathrm{L})\end{array}$ & $\begin{array}{c}\mathrm{Si} \\
(\mathrm{mg} / \mathrm{L})\end{array}$ & $\begin{array}{c}\mathrm{Fe} \\
(\mathrm{mg} / \mathrm{L})\end{array}$ & $\begin{array}{c}\mathrm{K} \\
(\mathrm{mg} / \mathrm{L})\end{array}$ \\
\hline & $25^{\circ} \mathrm{C}-\mathrm{b} 96 \mathrm{hr}$ & 1.9673 & 14.6357 & 1,230 & 15,100 & 74.8 & 393 & 1.5 & 0.57 & 91.0 \\
\hline \multirow{11}{*}{$\mathrm{T} 2-3$} & $85^{\circ} \mathrm{C}$ & 2.0784 & 14.5842 & 1,090 & 15,200 & 470 & 4.5 & 5.63 & 3.37 & 95.4 \\
\hline & $25^{\circ} \mathrm{C}-0 \mathrm{hr}$ & 1.9028 & 14.6491 & 982 & 13,600 & 61.0 & 3.5 & 3.62 & 1.74 & 85.9 \\
\hline & $25^{\circ} \mathrm{C}-1 \mathrm{hr}$ & 1.8022 & 14.5220 & 953 & 13,200 & 49.2 & 4.0 & 3.43 & 1.44 & 83.9 \\
\hline & $25^{\circ} \mathrm{C}-2 \mathrm{hr}$ & 1.9830 & 14.6939 & 1,040 & 14,300 & 46.9 & 3.6 & 3.60 & 0.895 & 92.7 \\
\hline & $25^{\circ} \mathrm{C}-4 \mathrm{hr}$ & 2.1745 & 14.6349 & 1,100 & 15,400 & 38.4 & 4.8 & 3.75 & 0.917 & 99.0 \\
\hline & $25^{\circ} \mathrm{C}-8 \mathrm{hr}$ & 2.4737 & 14.5557 & 1,400 & 18,500 & 41.0 & --- & 4.8 & 1.24 & 117 \\
\hline & $25^{\circ} \mathrm{C}-12 \mathrm{hr}$ & 2.6938 & 14.1919 & 1,550 & 20,200 & 40.4 & 13 & 5.4 & 1.42 & 129 \\
\hline & $25^{\circ} \mathrm{C}-24 \mathrm{hr}$ & 2.2044 & 14.6542 & 1,230 & 16,700 & 32 & 6.3 & 4.2 & 1.39 & 104 \\
\hline & $15^{\circ} \mathrm{C}$ & 2.1798 & 14.7643 & 1,190 & 16,300 & 24 & 12 & 4.2 & 1.53 & 101 \\
\hline & $25^{\circ} \mathrm{C}-\mathrm{b} 24 \mathrm{hr}$ & 1.8987 & 14.3184 & 1,070 & 14,800 & 22 & 12 & 3.5 & 0.72 & 90.6 \\
\hline & $25^{\circ} \mathrm{C}-\mathrm{b} 96 \mathrm{hr}$ & 2.1041 & 14.7122 & 1,150 & 15,500 & 25 & 6.1 & 3.5 & 0.82 & 96.3 \\
\hline \multirow{11}{*}{$\mathrm{T} 2-4$} & $85^{\circ} \mathrm{C}$ & 1.9295 & 14.6504 & 1,160 & 14,100 & 460 & 3.0 & 1.56 & 2.31 & 88.0 \\
\hline & $25^{\circ} \mathrm{C}-0 \mathrm{hr}$ & 1.8547 & 14.6407 & 1,080 & 13,900 & 435 & 3.3 & 1.36 & 1.00 & 81.6 \\
\hline & $25^{\circ} \mathrm{C}-1 \mathrm{hr}$ & 1.7289 & 14.5278 & 1,070 & 12,800 & 59.3 & 3.9 & 1.67 & 1.07 & 82.5 \\
\hline & $25^{\circ} \mathrm{C}-2 \mathrm{hr}$ & 1.6947 & 14.8147 & 1,030 & 12,300 & 55.5 & 4.1 & 1.2 & 0.842 & 79.8 \\
\hline & $25^{\circ} \mathrm{C}-4 \mathrm{hr}$ & 1.7707 & 14.5044 & 1,130 & 13,000 & 60.6 & 2.2 & 1.28 & 0.783 & 85.8 \\
\hline & $25^{\circ} \mathrm{C}-8 \mathrm{hr}$ & 2.2147 & 14.5003 & 1,410 & 15,600 & 74.0 & 4.6 & 1.69 & 0.826 & 108 \\
\hline & $25^{\circ} \mathrm{C}-12 \mathrm{hr}$ & 2.3471 & 14.5062 & 1,560 & 17,600 & 85.7 & 5.9 & 2.1 & 1.65 & 118 \\
\hline & $25^{\circ} \mathrm{C}-24 \mathrm{hr}$ & 1.4177 & 14.8626 & 933 & 10,900 & 53.6 & --- & 1.4 & 1.01 & 67.7 \\
\hline & $15^{\circ} \mathrm{C}$ & 2.1631 & 14.5262 & 1,410 & 16,300 & 40.7 & 6.3 & 1.9 & 0.62 & 104 \\
\hline & $25^{\circ} \mathrm{C}-\mathrm{b} 24 \mathrm{hr}$ & 2.2338 & 14.1825 & 1,450 & 17,200 & 82.0 & --- & 1.7 & 0.73 & 106 \\
\hline & $25^{\circ} \mathrm{C}-\mathrm{b} 96 \mathrm{hr}$ & 1.8569 & 14.9544 & 1,170 & 13,400 & 69.9 & --- & 1.3 & 0.47 & 85.9 \\
\hline \multirow{11}{*}{$\mathrm{T} 2-5$} & $85^{\circ} \mathrm{C}$ & 1.7839 & 14.5761 & 939 & 13,600 & 422 & 115 & 4.10 & 2.11 & 81.5 \\
\hline & $25^{\circ} \mathrm{C}-0 \mathrm{hr}$ & 1.9830 & 14.7133 & 1,030 & 14,500 & 64.8 & 117 & 3.22 & 0.897 & 90.2 \\
\hline & $25^{\circ} \mathrm{C}-1 \mathrm{hr}$ & 1.9396 & 14.5921 & 1,020 & 14,200 & 48.6 & 121 & 3.08 & 0.852 & 89.8 \\
\hline & $25^{\circ} \mathrm{C}-2 \mathrm{hr}$ & 2.0978 & 14.6534 & 1,090 & 15,200 & 45.2 & 131 & 3.24 & 0.907 & 96.7 \\
\hline & $25^{\circ} \mathrm{C}-4 \mathrm{hr}$ & 1.9987 & 14.4554 & 1,180 & 13,400 & 65.4 & --- & 1.3 & 0.84 & 87.9 \\
\hline & $25^{\circ} \mathrm{C}-8 \mathrm{hr}$ & 2.6800 & 14.5296 & 1,450 & 19,600 & 40.9 & 162 & 4.5 & 1.19 & 120 \\
\hline & $25^{\circ} \mathrm{C}-12 \mathrm{hr}$ & 2.2884 & 14.5495 & 1,220 & 16,200 & 30.9 & 141 & 3.63 & 1.13 & 106 \\
\hline & $25^{\circ} \mathrm{C}-24 \mathrm{hr}$ & 2.2854 & 14.3548 & 1,260 & 17,500 & 34 & 147 & 3.8 & 1.26 & 105 \\
\hline & $15^{\circ} \mathrm{C}$ & 2.0191 & 14.4203 & 1,150 & 15,700 & 21 & 136 & 3.2 & 0.85 & 95.0 \\
\hline & $25^{\circ} \mathrm{C}-\mathrm{b} 24 \mathrm{hr}$ & 1.9792 & 14.5692 & 1,090 & 15,100 & 24 & 118 & 3.0 & 0.70 & 91.2 \\
\hline & $25^{\circ} \mathrm{C}-\mathrm{b} 96 \mathrm{hr}$ & 1.8897 & 14.6265 & 1,160 & 15,800 & 19 & 123 & 3.3 & 0.83 & 96.1 \\
\hline \multirow{11}{*}{ T2-6 } & $85^{\circ} \mathrm{C}$ & 1.7960 & 14.7075 & 1,110 & 13,400 & 2.9 & 339 & 1.36 & 2.02 & 84.1 \\
\hline & $25^{\circ} \mathrm{C}-0 \mathrm{hr}$ & 1.9644 & 14.6695 & 1,170 & 14,400 & 3.1 & 388 & 1.37 & 1.22 & 89.0 \\
\hline & $25^{\circ} \mathrm{C}-1 \mathrm{hr}$ & 1.9153 & 14.4953 & 1,180 & 14,400 & 2.7 & 389 & 1.25 & 1.20 & 91.0 \\
\hline & $25^{\circ} \mathrm{C}-2 \mathrm{hr}$ & 2.0430 & 14.9063 & 1,200 & 14,700 & 2.3 & 391 & 1.35 & 1.24 & 92.7 \\
\hline & $25^{\circ} \mathrm{C}-4 \mathrm{hr}$ & 2.0169 & 14.4284 & 1,270 & 15,000 & 2.1 & 396 & 1.40 & 1.26 & 97.8 \\
\hline & $25^{\circ} \mathrm{C}-8 \mathrm{hr}$ & 2.2635 & 14.6261 & 1,460 & 17,100 & ---- & 451 & 2.4 & 1.48 & 108 \\
\hline & $25^{\circ} \mathrm{C}-12 \mathrm{hr}$ & 2.6059 & 14.5537 & 1,680 & 20,000 & 4.6 & 551 & 1.8 & 1.71 & 124 \\
\hline & $25^{\circ} \mathrm{C}-24 \mathrm{hr}$ & 2.0623 & 14.7645 & 1,300 & 15,600 & 8.4 & 430 & 1.8 & 1.21 & 95.5 \\
\hline & $15^{\circ} \mathrm{C}$ & 2.0792 & 14.6726 & 1,340 & 16,000 & 11 & 438 & 1.4 & 1.00 & 96.9 \\
\hline & $25^{\circ} \mathrm{C}-\mathrm{b} 24 \mathrm{hr}$ & 1.7681 & 14.4679 & 1,130 & 14,000 & 11 & 360 & 1.6 & 0.996 & 84.1 \\
\hline & $25^{\circ} \mathrm{C}-\mathrm{b} 96 \mathrm{hr}$ & 1.7895 & 14.6742 & 1,140 & 13,700 & --- & 354 & 1.3 & 0.83 & 82.8 \\
\hline \multirow[t]{5}{*}{$\mathrm{T} 2-7$} & $85^{\circ} \mathrm{C}$ & 1.8875 & 14.6665 & 1,010 & 13,700 & 3.2 & 3.7 & 4.09 & 2.93 & 89.2 \\
\hline & $25^{\circ} \mathrm{C}-0 \mathrm{hr}$ & 2.1034 & 14.6025 & 1,090 & 15,200 & 3.1 & 4.5 & 3.87 & 1.28 & 96.3 \\
\hline & $25^{\circ} \mathrm{C}-1 \mathrm{hr}$ & 2.0705 & 14.3632 & 1,110 & 15,300 & 3.5 & 4.5 & 3.84 & 1.51 & 99.2 \\
\hline & $25^{\circ} \mathrm{C}-2 \mathrm{hr}$ & 1.8141 & 14.7511 & 948 & 13,200 & 1.9 & 4.9 & 3.46 & 1.27 & 85.0 \\
\hline & $25^{\circ} \mathrm{C}-4 \mathrm{hr}$ & 2.4228 & 14.7919 & 994 & 13,400 & 2.6 & 4.5 & 3.42 & 1.20 & 88.2 \\
\hline
\end{tabular}


Table A.1. ICP Results for Task 2 Supernate

\begin{tabular}{|c|c|c|c|c|c|c|c|c|c|c|}
\hline \multirow[t]{7}{*}{$\begin{array}{c}\text { Test } \\
\text { ID }\end{array}$} & Sample ID & $\begin{array}{c}\text { Sample Wt } \\
(\mathrm{g})\end{array}$ & DIW (g) & $\begin{array}{c}\mathrm{Al} \\
(\mathrm{mg} / \mathrm{L})\end{array}$ & $\begin{array}{c}\mathrm{Na} \\
(\mathrm{mg} / \mathrm{L})\end{array}$ & $\begin{array}{c}\mathrm{P} \\
(\mathrm{mg} / \mathrm{L})\end{array}$ & $\begin{array}{c}\mathrm{S} \\
(\mathrm{mg} / \mathrm{L})\end{array}$ & $\begin{array}{c}\mathrm{Si} \\
(\mathrm{mg} / \mathrm{L})\end{array}$ & $\begin{array}{c}\mathrm{Fe} \\
(\mathrm{mg} / \mathrm{L})\end{array}$ & $\begin{array}{c}\mathrm{K} \\
(\mathrm{mg} / \mathrm{L})\end{array}$ \\
\hline & $25^{\circ} \mathrm{C}-8 \mathrm{hr}$ & 1.9031 & 14.4453 & 1,050 & 13,700 & 2.8 & 4.7 & 3.62 & 1.29 & 92.0 \\
\hline & $25^{\circ} \mathrm{C}-12 \mathrm{hr}$ & 2.6049 & 14.5551 & 1,480 & 20,000 & 4.4 & 7.2 & 4.9 & 1.90 & 126 \\
\hline & $25^{\circ} \mathrm{C}-24 \mathrm{hr}$ & 2.1033 & 14.3416 & 1,190 & 16,200 & 9.4 & 14 & 4.2 & 1.71 & 101 \\
\hline & $15^{\circ} \mathrm{C}$ & 2.1423 & 14.7736 & 1,190 & 16,200 & 8.9 & ---- & 4.4 & 1.20 & 103 \\
\hline & $25^{\circ} \mathrm{C}-\mathrm{b} 24 \mathrm{hr}$ & 1.8924 & 14.6728 & 1,040 & 14,500 & 14 & --- & 3.2 & 0.83 & 89.0 \\
\hline & $25^{\circ} \mathrm{C}-\mathrm{b} 96 \mathrm{hr}$ & 1.7792 & 14.5848 & 985 & 13,500 & --- & --- & 3.4 & 1.07 & 82.6 \\
\hline \multirow{11}{*}{$\mathrm{T} 2-8$} & $85^{\circ} \mathrm{C}$ & 2.2064 & 14.4293 & 1,250 & 14,400 & 3.6 & 3.8 & 1.44 & 2.73 & 97.2 \\
\hline & $25^{\circ} \mathrm{C}-0 \mathrm{hr}$ & 2.2816 & 14.7210 & 1,380 & 16,200 & 2.7 & 5.0 & 1.66 & 1.59 & 108 \\
\hline & $25^{\circ} \mathrm{C}-1 \mathrm{hr}$ & 2.1011 & 14.4441 & 1,310 & 15,300 & 2.2 & 4.2 & 1.63 & 1.50 & 101 \\
\hline & $25^{\circ} \mathrm{C}-2 \mathrm{hr}$ & 2.2037 & 14.4611 & 1,340 & 15,600 & 3.4 & 5.1 & 1.45 & 1.30 & 106 \\
\hline & $25^{\circ} \mathrm{C}-4 \mathrm{hr}$ & 2.3403 & 14.4867 & 1,550 & 17,600 & 4.3 & --- & 1.8 & 1.90 & 114 \\
\hline & $25^{\circ} \mathrm{C}-8 \mathrm{hr}$ & 2.4455 & 14.5387 & 1,610 & 17,800 & --- & ---- & 2.1 & 1.90 & 119 \\
\hline & $25^{\circ} \mathrm{C}-12 \mathrm{hr}$ & 2.6974 & 14.7022 & 1,740 & 19,900 & ---- & 16 & 1.9 & 1.89 & 128 \\
\hline & $25^{\circ} \mathrm{C}-24 \mathrm{hr}$ & 1.9945 & 14.6163 & 1,320 & 15,500 & 9.8 & 9.3 & 1.7 & 1.48 & 95.0 \\
\hline & $15^{\circ} \mathrm{C}$ & 2.2289 & 14.4289 & 1,450 & 16,700 & --- & 7.4 & 1.6 & 0.80 & 108 \\
\hline & $25^{\circ} \mathrm{C}-\mathrm{b} 24 \mathrm{hr}$ & 2.2675 & 14.3639 & 1,460 & 17,000 & 8.0 & 11 & 1.7 & 0.982 & 109 \\
\hline & $25^{\circ} \mathrm{C}-\mathrm{b} 96 \mathrm{hr}$ & 2.2303 & 14.6369 & 1,370 & 15,800 & --- & --- & 1.8 & 1.29 & 101 \\
\hline \multirow{11}{*}{ T2-9 } & $85^{\circ} \mathrm{C}$ & 1.9753 & 14.7040 & 1,230 & 14,000 & 3.5 & 3.0 & 1.43 & 2.79 & 94.3 \\
\hline & $25^{\circ} \mathrm{C}-0 \mathrm{hr}$ & 2.4214 & 14.4338 & 1,560 & 18,200 & --- & 8.3 & 1.5 & 1.60 & 114 \\
\hline & $25^{\circ} \mathrm{C}-1 \mathrm{hr}$ & 2.0979 & 14.7994 & 1,280 & 14,900 & 2.9 & 4.3 & 1.51 & 1.32 & 98.4 \\
\hline & $25^{\circ} \mathrm{C}-2 \mathrm{hr}$ & 1.6679 & 14.4493 & 1,040 & 12,500 & 2.3 & 3.0 & 1.1 & 1.01 & 81.3 \\
\hline & $25^{\circ} \mathrm{C}-4 \mathrm{hr}$ & 1.9033 & 14.5538 & 1,200 & 13,800 & 2.4 & 3.6 & 1.37 & 1.23 & 92.1 \\
\hline & $25^{\circ} \mathrm{C}-8 \mathrm{hr}$ & 2.1504 & 14.1977 & 1,370 & 15,200 & 3.6 & 5.6 & 1.56 & 1.29 & 105 \\
\hline & $25^{\circ} \mathrm{C}-12 \mathrm{hr}$ & 2.6758 & 14.3778 & 1,760 & 20,000 & --- & ---- & 2.2 & 1.71 & 128 \\
\hline & $25^{\circ} \mathrm{C}-24 \mathrm{hr}$ & 1.8892 & 14.2807 & 1,270 & 15,100 & 10 & 13 & 1.5 & 1.21 & 94.8 \\
\hline & $15^{\circ} \mathrm{C}$ & 2.2648 & 14.5778 & 1,450 & 16,700 & 7.0 & --- & 1.3 & 1.02 & 106 \\
\hline & $25^{\circ} \mathrm{C}-\mathrm{b} 24 \mathrm{hr}$ & 2.0236 & 14.4929 & 1,330 & 15,400 & 8.3 & 14 & 1.8 & 1.06 & 97.3 \\
\hline & $25^{\circ} \mathrm{C}-\mathrm{b} 96 \mathrm{hr}$ & 2.2298 & 14.5495 & 1,400 & 16,100 & --- & --- & 1.7 & 1.36 & 102 \\
\hline
\end{tabular}


Table A.2. IC Results for Task 2 Supernate

\begin{tabular}{|c|c|c|c|c|c|c|c|c|c|}
\hline Test ID & Sample ID & $\begin{array}{l}\text { Sample Wt } \\
\text { (g) }\end{array}$ & DIW (g) & $\begin{array}{c}\mathrm{C}_{2} \mathrm{O}_{4} \\
(\mathrm{mg} / \mathrm{L})\end{array}$ & $\begin{array}{c}\mathrm{PO}_{4} \\
(\mathrm{mg} / \mathrm{L})\end{array}$ & $\begin{array}{c}\mathrm{SO}_{4} \\
(\mathrm{mg} / \mathrm{L})\end{array}$ & $\begin{array}{c}\mathrm{F} \\
(\mathrm{mg} / \mathrm{L})\end{array}$ & $\begin{array}{c}\mathrm{NO}_{3} \\
(\mathrm{mg} / \mathrm{L})\end{array}$ & $\begin{array}{c}\mathrm{NO}_{2} \\
(\mathrm{mg} / \mathrm{L})\end{array}$ \\
\hline \multirow{11}{*}{ T2-1a } & $85^{\circ} \mathrm{C}$ & 1.9347 & 14.5796 & 55 & 1,480 & 433 & 136 & 6,430 & 1,440 \\
\hline & $25^{\circ} \mathrm{C}-0 \mathrm{hr}$ & 2.0784 & 14.7004 & 22 & 175 & 461 & 50 & 7,130 & 1,600 \\
\hline & $25^{\circ} \mathrm{C}-1 \mathrm{hr}$ & 2.0404 & 14.6059 & 21 & 147 & 454 & 48 & 7,060 & 1,580 \\
\hline & $25^{\circ} \mathrm{C}-2 \mathrm{hr}$ & 1.8480 & 14.6221 & 21 & 124 & 414 & 43 & 6,470 & 1,420 \\
\hline & $25^{\circ} \mathrm{C}-4 \mathrm{hr}$ & 2.9329 & 13.6433 & 19 & 113 & 433 & 43 & 6,590 & 1,460 \\
\hline & $25^{\circ} \mathrm{C}-8 \mathrm{hr}$ & 2.1474 & 14.2005 & 20 & 117 & 491 & 48 & 7,490 & 1,650 \\
\hline & $25^{\circ} \mathrm{C}-12 \mathrm{hr}$ & 2.2690 & 14.5718 & 22 & 117 & 505 & 49 & 7,770 & 1,720 \\
\hline & $25^{\circ} \mathrm{C}-24 \mathrm{hr}$ & 2.4826 & 14.5781 & 19 & 116 & 547 & 53 & 8,430 & 1,870 \\
\hline & $15^{\circ} \mathrm{C}$ & 2.2433 & 14.7031 & 18 & 69 & 495 & 46 & 7,690 & 1,710 \\
\hline & $25^{\circ} \mathrm{C}-24 \mathrm{hr}$ & 2.1247 & 14.7548 & 16 & 96 & 469 & 48 & 7,280 & 1,610 \\
\hline & $25^{\circ} \mathrm{C}-96 \mathrm{hr}$ & 1.9635 & 14.9026 & 14 & 87 & 427 & 46 & 6,650 & 1,470 \\
\hline \multirow{11}{*}{$\mathrm{T} 2-1 \mathrm{~b}$} & $85^{\circ} \mathrm{C}$ & 1.9840 & 14.6905 & 57 & 1,480 & 449 & 140 & 6,380 & 1,450 \\
\hline & $25^{\circ} \mathrm{C}-0 \mathrm{hr}$ & 2.0413 & 14.6731 & 23 & 182 & 463 & 46 & 6,840 & 1,550 \\
\hline & $25^{\circ} \mathrm{C}-1 \mathrm{hr}$ & 2.0380 & 14.6793 & 24 & 156 & 462 & 43 & 6,860 & 1,550 \\
\hline & $25^{\circ} \mathrm{C}-2 \mathrm{hr}$ & 2.1003 & 14.5745 & 24 & 147 & 480 & 43 & 7,160 & 1,600 \\
\hline & $25^{\circ} \mathrm{C}-4 \mathrm{hr}$ & 2.0558 & 14.8148 & 21 & 124 & 462 & 40 & 6,740 & 1,510 \\
\hline & $25^{\circ} \mathrm{C}-8 \mathrm{hr}$ & 2.2809 & 14.2522 & 24 & 131 & 526 & 45 & 7,700 & 1,720 \\
\hline & $25^{\circ} \mathrm{C}-12 \mathrm{hr}$ & 2.6159 & 14.6052 & 25 & 138 & 587 & 49 & 8,520 & 1,860 \\
\hline & $25^{\circ} \mathrm{C}-24 \mathrm{hr}$ & 2.4337 & 14.9196 & 20 & 117 & 537 & 46 & 7,940 & 1,780 \\
\hline & $15^{\circ} \mathrm{C}$ & 2.0434 & 14.7266 & 17 & 64 & 464 & 38 & 6,890 & 1,550 \\
\hline & $25^{\circ} \mathrm{C}-24 \mathrm{hr}$ & 2.0906 & 14.7012 & 16 & 99 & 479 & 44 & 7,100 & 1,590 \\
\hline & $25^{\circ} \mathrm{C}-96 \mathrm{hr}$ & 1.9644 & 14.8275 & 16 & 94 & 439 & 44 & 6,560 & 1,460 \\
\hline \multirow{11}{*}{$\mathrm{T} 2-1 \mathrm{c}$} & $85^{\circ} \mathrm{C}$ & 1.8050 & 14.5581 & 52 & 1,350 & 399 & 134 & 5,890 & 1,330 \\
\hline & $25^{\circ} \mathrm{C}-0 \mathrm{hr}$ & 1.7735 & 14.7670 & 20 & 145 & 384 & 48 & 6,100 & 1,380 \\
\hline & $25^{\circ} \mathrm{C}-1 \mathrm{hr}$ & 1.6038 & 14.5611 & 17 & 113 & 354 & 42 & 5,540 & 1,250 \\
\hline & $25^{\circ} \mathrm{C}-2 \mathrm{hr}$ & 2.0213 & 14.7139 & 22 & 128 & 435 & 56 & 6,820 & 1,520 \\
\hline & $25^{\circ} \mathrm{C}-4 \mathrm{hr}$ & 2.1133 & 14.7556 & 21 & 118 & 452 & 51 & 6,970 & 1,560 \\
\hline & $25^{\circ} \mathrm{C}-8 \mathrm{hr}$ & 1.7146 & 14.3404 & 16 & 88 & 383 & 44 & 5,930 & 1,320 \\
\hline & $25^{\circ} \mathrm{C}-12 \mathrm{hr}$ & 2.5116 & 14.5171 & 23 & 119 & 537 & 59 & 8,320 & 1,880 \\
\hline & $25^{\circ} \mathrm{C}-24 \mathrm{hr}$ & 2.0306 & 14.7696 & 18 & 92 & 436 & 50 & 6,780 & 1,520 \\
\hline & $15^{\circ} \mathrm{C}$ & 2.1823 & 14.4569 & 17 & 62 & 475 & 52 & 7,470 & 1,680 \\
\hline & $25^{\circ} \mathrm{C}-24 \mathrm{hr}$ & 2.1155 & 14.5348 & 18 & 93 & 457 & 57 & 7,190 & 1,610 \\
\hline & $25^{\circ} \mathrm{C}-96 \mathrm{hr}$ & 2.1425 & 14.6962 & 16 & 89 & 451 & 58 & 7,160 & 1,590 \\
\hline \multirow{11}{*}{ T2-2 } & $85^{\circ} \mathrm{C}$ & 1.8534 & 14.6473 & 52 & 1,400 & 1,090 & $<3$ & 6,120 & 1,370 \\
\hline & $25^{\circ} \mathrm{C}-0 \mathrm{hr}$ & 2.0774 & 14.7051 & 20 & 1,510 & 1,210 & $<3$ & 6,780 & 1,520 \\
\hline & $25^{\circ} \mathrm{C}-1 \mathrm{hr}$ & 1.8355 & 14.5439 & 17 & 201 & 1,120 & $<3$ & 6,420 & 1,430 \\
\hline & $25^{\circ} \mathrm{C}-2 \mathrm{hr}$ & 2.0746 & 14.6716 & 19 & 231 & 1,240 & $<3$ & 7,110 & 1,560 \\
\hline & $25^{\circ} \mathrm{C}-4 \mathrm{hr}$ & 1.8476 & 14.6463 & 15 & 205 & 1,120 & $<3$ & 6,310 & 1,390 \\
\hline & $25^{\circ} \mathrm{C}-8 \mathrm{hr}$ & 2.1863 & 14.5029 & 17 & 233 & 1,290 & $<3$ & 7,440 & 1,640 \\
\hline & $25^{\circ} \mathrm{C}-12 \mathrm{hr}$ & 2.2154 & 14.2873 & 19 & 256 & 1,350 & $<3$ & 7,690 & 1,710 \\
\hline & $25^{\circ} \mathrm{C}-24 \mathrm{hr}$ & 1.7871 & 14.5852 & 14 & 194 & 1,100 & $<3$ & 6,240 & 1,380 \\
\hline & $15^{\circ} \mathrm{C}$ & 2.1842 & 14.2713 & 17 & 116 & 1,350 & $<3$ & 7,680 & 1,710 \\
\hline & $25^{\circ} \mathrm{C}-24 \mathrm{hr}$ & 1.9851 & 14.4748 & 15 & 220 & 1,220 & $<3$ & 6,960 & 1,530 \\
\hline & $25^{\circ} \mathrm{C}-96 \mathrm{hr}$ & 1.9673 & 14.6357 & 18 & 199 & 1,170 & $<3$ & 6,770 & 1,490 \\
\hline \multirow[t]{4}{*}{$\mathrm{T} 2-3$} & $85^{\circ} \mathrm{C}$ & 2.0784 & 14.5842 & $<4$ & 1,460 & 11 & 196 & 6,780 & 1,540 \\
\hline & $25^{\circ} \mathrm{C}-0 \mathrm{hr}$ & 1.9028 & 14.6491 & $<4$ & 204 & 10 & 77 & 6,450 & 1,460 \\
\hline & $25^{\circ} \mathrm{C}-1 \mathrm{hr}$ & 1.8022 & 14.5220 & $<4$ & 162 & 10 & 74 & 6,220 & 1,410 \\
\hline & $25^{\circ} \mathrm{C}-2 \mathrm{hr}$ & 1.9830 & 14.6939 & $<4$ & 156 & 10 & 81 & 6,730 & 1,500 \\
\hline
\end{tabular}


Table A.2. IC Results for Task 2 Supernate

\begin{tabular}{|c|c|c|c|c|c|c|c|c|c|}
\hline Test ID & Sample ID & $\begin{array}{c}\text { Sample Wt } \\
(\mathrm{g})\end{array}$ & DIW (g) & $\begin{array}{c}\mathrm{C}_{2} \mathrm{O}_{4} \\
(\mathrm{mg} / \mathrm{L}) \\
\end{array}$ & $\begin{array}{c}\mathrm{PO}_{4} \\
(\mathrm{mg} / \mathrm{L})\end{array}$ & $\begin{array}{c}\mathrm{SO}_{4} \\
(\mathrm{mg} / \mathrm{L})\end{array}$ & $\begin{array}{c}\mathrm{F} \\
(\mathrm{mg} / \mathrm{L})\end{array}$ & $\begin{array}{c}\mathrm{NO}_{3} \\
(\mathrm{mg} / \mathrm{L})\end{array}$ & $\begin{array}{c}\mathrm{NO}_{2} \\
(\mathrm{mg} / \mathrm{L})\end{array}$ \\
\hline & $25^{\circ} \mathrm{C}-4 \mathrm{hr}$ & 2.1745 & 14.6349 & $<4$ & 136 & 11 & 90 & 7,240 & 1,620 \\
\hline & $25^{\circ} \mathrm{C}-8 \mathrm{hr}$ & 2.4737 & 14.5557 & $<4$ & 124 & 13 & 102 & 8,100 & 1,780 \\
\hline & $25^{\circ} \mathrm{C}-12 \mathrm{hr}$ & 2.6938 & 14.1919 & $<4$ & 124 & 14 & 113 & 9,070 & 2,040 \\
\hline & $25^{\circ} \mathrm{C}-24 \mathrm{hr}$ & 2.2044 & 14.6542 & $<4$ & 85 & 11 & 95 & 7,450 & 1,670 \\
\hline & $15^{\circ} \mathrm{C}$ & 2.1798 & 14.7643 & $<4$ & 55 & 11 & 92 & 7,330 & 1,640 \\
\hline & $25^{\circ} \mathrm{C}-24 \mathrm{hr}$ & 1.8987 & 14.3184 & $<4$ & 67 & 10 & 87 & 6,650 & 1,480 \\
\hline & $25^{\circ} \mathrm{C}-96 \mathrm{hr}$ & 2.1041 & 14.7122 & $<4$ & 70 & 11 & 93 & 7,050 & 1,570 \\
\hline \multirow{11}{*}{ T2-4 } & $85^{\circ} \mathrm{C}$ & 1.9295 & 14.6504 & $<4$ & 1,460 & 10 & $<3$ & 6,430 & 1,440 \\
\hline & $25^{\circ} \mathrm{C}-0 \mathrm{hr}$ & 1.8547 & 14.6407 & $<4$ & 1,420 & 10 & $<3$ & 6,200 & 1,390 \\
\hline & $25^{\circ} \mathrm{C}-1 \mathrm{hr}$ & 1.7289 & 14.5278 & $<4$ & 196 & 9 & $<3$ & 6,160 & 1,470 \\
\hline & $25^{\circ} \mathrm{C}-2 \mathrm{hr}$ & 1.6947 & 14.8147 & $<4$ & 183 & 9 & $<3$ & 5,960 & 1,310 \\
\hline & $25^{\circ} \mathrm{C}-4 \mathrm{hr}$ & 1.7707 & 14.5044 & $<4$ & 201 & 9 & $<3$ & 6,200 & 1,370 \\
\hline & $25^{\circ} \mathrm{C}-8 \mathrm{hr}$ & 2.2147 & 14.5003 & $<4$ & 237 & 14 & $<3$ & 7,640 & 1,690 \\
\hline & $25^{\circ} \mathrm{C}-12 \mathrm{hr}$ & 2.3471 & 14.5062 & $<4$ & 258 & 12 & $<3$ & 8,080 & 1,800 \\
\hline & $25^{\circ} \mathrm{C}-24 \mathrm{hr}$ & 1.4177 & 14.8626 & $<4$ & 147 & 8 & $<3$ & 5,020 & 1,110 \\
\hline & $15^{\circ} \mathrm{C}$ & 2.1631 & 14.5262 & $<4$ & 106 & 12 & $<3$ & 7,610 & 1,680 \\
\hline & $25^{\circ} \mathrm{C}-24 \mathrm{hr}$ & 2.2338 & 14.1825 & $<4$ & 262 & 12 & $<3$ & 7,980 & 1,760 \\
\hline & $25^{\circ} \mathrm{C}-96 \mathrm{hr}$ & 1.8569 & 14.9544 & $<4$ & 209 & 10 & $<3$ & 6,370 & 1,400 \\
\hline \multirow{11}{*}{$\mathrm{T} 2-5$} & $85^{\circ} \mathrm{C}$ & 1.7839 & 14.5761 & $<4$ & 1,370 & 361 & 148 & 5,850 & 1,320 \\
\hline & $25^{\circ} \mathrm{C}-0 \mathrm{hr}$ & 1.9830 & 14.7133 & $<4$ & 218 & 380 & 76 & 6,640 & 1,500 \\
\hline & $25^{\circ} \mathrm{C}-1 \mathrm{hr}$ & 1.9396 & 14.5921 & $<4$ & 162 & 371 & 74 & 6,580 & 1,490 \\
\hline & $25^{\circ} \mathrm{C}-2 \mathrm{hr}$ & 2.0978 & 14.6534 & $<4$ & 153 & 402 & 81 & 7,080 & 1,580 \\
\hline & $25^{\circ} \mathrm{C}-4 \mathrm{hr}$ & 1.9987 & 14.4554 & $<4$ & 121 & 387 & 80 & 6,790 & 1,510 \\
\hline & $25^{\circ} \mathrm{C}-8 \mathrm{hr}$ & 2.6800 & 14.5296 & $<4$ & 128 & 499 & 105 & 8,810 & 1,980 \\
\hline & $25^{\circ} \mathrm{C}-12 \mathrm{hr}$ & 2.2884 & 14.5495 & $<4$ & 100 & 437 & 93 & 7,710 & 1,730 \\
\hline & $25^{\circ} \mathrm{C}-24 \mathrm{hr}$ & 2.2854 & 14.3548 & $<4$ & 88 & 438 & 96 & 7,780 & 1,740 \\
\hline & $15^{\circ} \mathrm{C}$ & 2.0191 & 14.4203 & $<4$ & 49 & 390 & 84 & 6,940 & 1,560 \\
\hline & $25^{\circ} \mathrm{C}-24 \mathrm{hr}$ & 1.9792 & 14.5692 & $<4$ & 66 & 375 & 85 & 6,790 & 1,520 \\
\hline & $25^{\circ} \mathrm{C}-96 \mathrm{hr}$ & 1.8897 & 14.6265 & $<4$ & 68 & 383 & 90 & 7,140 & 1,590 \\
\hline \multirow{11}{*}{ T2-6 } & $85^{\circ} \mathrm{C}$ & 1.7960 & 14.7075 & $<4$ & 10 & 1,110 & $<3$ & 6,230 & 1,390 \\
\hline & $25^{\circ} \mathrm{C}-0 \mathrm{hr}$ & 1.9644 & 14.6695 & $<4$ & 10 & 1,210 & $<3$ & 6,780 & 1,520 \\
\hline & $25^{\circ} \mathrm{C}-1 \mathrm{hr}$ & 1.9153 & 14.4953 & $<4$ & 10 & 1,190 & $<3$ & 6,710 & 1,500 \\
\hline & $25^{\circ} \mathrm{C}-2 \mathrm{hr}$ & 2.0430 & 14.9063 & $<4$ & 10 & 1,230 & $<3$ & 6,950 & 1,530 \\
\hline & $25^{\circ} \mathrm{C}-4 \mathrm{hr}$ & 2.0169 & 14.4284 & $<4$ & 10 & 1,230 & $<3$ & 6,970 & 1,540 \\
\hline & $25^{\circ} \mathrm{C}-8 \mathrm{hr}$ & 2.2635 & 14.6261 & $<4$ & 11 & 1,370 & $<3$ & 7,730 & 1,710 \\
\hline & $25^{\circ} \mathrm{C}-12 \mathrm{hr}$ & 2.6059 & 14.5537 & $<4$ & 13 & 1,570 & $<3$ & 8,810 & 1,950 \\
\hline & $25^{\circ} \mathrm{C}-24 \mathrm{hr}$ & 2.0623 & 14.7645 & $<4$ & 10 & 1,260 & $<3$ & 7,120 & 1,580 \\
\hline & $15^{\circ} \mathrm{C}$ & 2.0792 & 14.6726 & $<4$ & 11 & 1,280 & $<3$ & 7,200 & 1,590 \\
\hline & $25^{\circ} \mathrm{C}-24 \mathrm{hr}$ & 1.7681 & 14.4679 & $<4$ & 9 & 1,120 & $<3$ & 6,260 & 1,380 \\
\hline & $25^{\circ} \mathrm{C}-96 \mathrm{hr}$ & 1.7895 & 14.6742 & $<4$ & 9 & 1,110 & $<3$ & 6,210 & 1,370 \\
\hline \multirow[t]{7}{*}{ T2-7 } & $85^{\circ} \mathrm{C}$ & 1.8875 & 14.6665 & 50 & 10 & 12 & 133 & 6,480 & 1,470 \\
\hline & $25^{\circ} \mathrm{C}-0 \mathrm{hr}$ & 2.1034 & 14.6025 & 21 & 11 & 13 & 146 & 7,160 & 1,620 \\
\hline & $25^{\circ} \mathrm{C}-1 \mathrm{hr}$ & 2.0705 & 14.3632 & 19 & 11 & 13 & 145 & 7,190 & 1,630 \\
\hline & $25^{\circ} \mathrm{C}-2 \mathrm{hr}$ & 1.8141 & 14.7511 & 17 & 9 & 11 & 127 & 6,190 & 1,380 \\
\hline & $25^{\circ} \mathrm{C}-4 \mathrm{hr}$ & 2.4228 & 14.7919 & 16 & 9 & 11 & 129 & 6,230 & 1,390 \\
\hline & $25^{\circ} \mathrm{C}-8 \mathrm{hr}$ & 1.9031 & 14.4453 & 16 & 10 & 12 & 135 & 6,630 & 1,490 \\
\hline & $25^{\circ} \mathrm{C}-12 \mathrm{hr}$ & 2.6049 & 14.5551 & 21 & 13 & 16 & 174 & 8,710 & 1,960 \\
\hline
\end{tabular}


Table A.2. IC Results for Task 2 Supernate

\begin{tabular}{|c|c|c|c|c|c|c|c|c|c|}
\hline Test ID & Sample ID & $\begin{array}{c}\text { Sample Wt } \\
(\mathrm{g})\end{array}$ & DIW (g) & $\begin{array}{c}\mathrm{C}_{2} \mathrm{O}_{4} \\
(\mathrm{mg} / \mathrm{L}) \\
\end{array}$ & $\begin{array}{c}\mathrm{PO}_{4} \\
(\mathrm{mg} / \mathrm{L}) \\
\end{array}$ & $\begin{array}{c}\mathrm{SO}_{4} \\
(\mathrm{mg} / \mathrm{L})\end{array}$ & $\begin{array}{c}\mathrm{F} \\
(\mathrm{mg} / \mathrm{L})\end{array}$ & $\begin{array}{c}\mathrm{NO}_{3} \\
(\mathrm{mg} / \mathrm{L}) \\
\end{array}$ & $\begin{array}{c}\mathrm{NO}_{2} \\
(\mathrm{mg} / \mathrm{L}) \\
\end{array}$ \\
\hline & $25^{\circ} \mathrm{C}-24 \mathrm{hr}$ & 2.1033 & 14.3416 & 18 & 11 & 13 & 147 & 7,340 & 1,650 \\
\hline & $15^{\circ} \mathrm{C}$ & 2.1423 & 14.7736 & 15 & 11 & 13 & 147 & 7,290 & 1,630 \\
\hline & $25^{\circ} \mathrm{C}-24 \mathrm{hr}$ & 1.8924 & 14.6728 & 14 & 10 & 12 & 130 & 6,520 & 1,450 \\
\hline & $25^{\circ} \mathrm{C}-96 \mathrm{hr}$ & 1.7792 & 14.5848 & 14 & 9 & 11 & 123 & 6,180 & 1,380 \\
\hline \multirow{11}{*}{ T2-8 } & $85^{\circ} \mathrm{C}$ & 2.2064 & 14.4293 & 55 & 10 & 13 & $<3$ & 7,030 & 1,570 \\
\hline & $25^{\circ} \mathrm{C}-0 \mathrm{hr}$ & 2.2816 & 14.7210 & 26 & 11 & 14 & $<3$ & 7,820 & 1,750 \\
\hline & $25^{\circ} \mathrm{C}-1 \mathrm{hr}$ & 2.1011 & 14.4441 & 17 & 11 & 14 & $<3$ & 7,450 & 1,660 \\
\hline & $25^{\circ} \mathrm{C}-2 \mathrm{hr}$ & 2.2037 & 14.4611 & 18 & 11 & 14 & $<3$ & 7,730 & 1,720 \\
\hline & $25^{\circ} \mathrm{C}-4 \mathrm{hr}$ & 2.3403 & 14.4867 & 18 & 12 & 15 & $<3$ & 8,080 & 1,780 \\
\hline & $25^{\circ} \mathrm{C}-8 \mathrm{hr}$ & 2.4455 & 14.5387 & 17 & 12 & 15 & $<3$ & 8,420 & 1,870 \\
\hline & $25^{\circ} \mathrm{C}-12 \mathrm{hr}$ & 2.6974 & 14.7022 & 19 & 13 & 17 & $<3$ & 9,110 & 2,020 \\
\hline & $25^{\circ} \mathrm{C}-24 \mathrm{hr}$ & 1.9945 & 14.6163 & 16 & 10 & 13 & $<3$ & 7,080 & 1,560 \\
\hline & $15^{\circ} \mathrm{C}$ & 2.2289 & 14.4289 & 15 & 11 & 14 & $<3$ & 7,880 & 1,740 \\
\hline & $25^{\circ} \mathrm{C}-24 \mathrm{hr}$ & 2.2675 & 14.3639 & 16 & 12 & 15 & $<3$ & 8,000 & 1,770 \\
\hline & $25^{\circ} \mathrm{C}-96 \mathrm{hr}$ & 2.2303 & 14.6369 & 17 & 11 & 14 & $<3$ & 7,740 & 1,710 \\
\hline \multirow{11}{*}{ T2-9 } & $85^{\circ} \mathrm{C}$ & 1.9753 & 14.7040 & $<4$ & 10 & 11 & $<3$ & 6,910 & 1,550 \\
\hline & $25^{\circ} \mathrm{C}-0 \mathrm{hr}$ & 2.4214 & 14.4338 & $<4$ & 12 & 13 & $<3$ & 8,460 & 1,890 \\
\hline & $25^{\circ} \mathrm{C}-1 \mathrm{hr}$ & 2.0979 & 14.7994 & $<4$ & 10 & 11 & $<3$ & 7,260 & 1,620 \\
\hline & $25^{\circ} \mathrm{C}-2 \mathrm{hr}$ & 1.6679 & 14.4493 & $<4$ & 9 & 9 & $<3$ & 5,810 & 1,270 \\
\hline & $25^{\circ} \mathrm{C}-4 \mathrm{hr}$ & 1.9033 & 14.5538 & $<4$ & 10 & 10 & $<3$ & 6,660 & 1,470 \\
\hline & $25^{\circ} \mathrm{C}-8 \mathrm{hr}$ & 2.1504 & 14.1977 & $<4$ & 11 & 12 & $<3$ & 7,600 & 1,690 \\
\hline & $25^{\circ} \mathrm{C}-12 \mathrm{hr}$ & 2.6758 & 14.3778 & $<4$ & 13 & 14 & $<3$ & 9,260 & 2,050 \\
\hline & $25^{\circ} \mathrm{C}-24 \mathrm{hr}$ & 1.8892 & 14.2807 & $<4$ & 9 & 10 & $<3$ & 6,880 & 1,520 \\
\hline & $15^{\circ} \mathrm{C}$ & 2.2648 & 14.5778 & $<4$ & 12 & 12 & $<3$ & 7,920 & 1,750 \\
\hline & $25^{\circ} \mathrm{C}-24 \mathrm{hr}$ & 2.0236 & 14.4929 & $<4$ & 10 & 11 & $<3$ & 7,160 & 1,580 \\
\hline & $25^{\circ} \mathrm{C}-96 \mathrm{hr}$ & 2.2298 & 14.5495 & $<4$ & 12 & 12 & $<3$ & 7,770 & 1,710 \\
\hline
\end{tabular}


Table A.3. ICP Results for Task 3 Supernate

\begin{tabular}{|c|c|c|c|c|c|c|c|c|c|}
\hline $\begin{array}{c}\text { Sample } \\
\text { ID }\end{array}$ & $\begin{array}{c}\text { Sample } \\
\mathrm{Wt}(\mathrm{g})\end{array}$ & $\begin{array}{c}\text { DIW Wt } \\
(\mathrm{g})\end{array}$ & $\begin{array}{c}\mathrm{Al} \\
(\mathrm{mg} / \mathrm{L}) \\
\end{array}$ & $\begin{array}{c}\mathrm{Fe} \\
(\mathrm{mg} / \mathrm{L}) \\
\end{array}$ & $\begin{array}{c}\mathrm{Na} \\
(\mathrm{mg} / \mathrm{L}) \\
\end{array}$ & $\begin{array}{c}\mathrm{P} \\
(\mathrm{mg} / \mathrm{L}) \\
\end{array}$ & $\begin{array}{c}\mathrm{S} \\
(\mathrm{mg} / \mathrm{L}) \\
\end{array}$ & $\begin{array}{c}\mathrm{Si} \\
(\mathrm{mg} / \mathrm{L}) \\
\end{array}$ & $\begin{array}{c}\mathrm{K} \\
(\mathrm{mg} / \mathrm{L}) \\
\end{array}$ \\
\hline T3-1a-35 & 1.9441 & 14.8330 & 1,180 & 1.78 & 15,000 & 35 & 111 & 45.9 & 89.2 \\
\hline T3-1a-20 & 2.1873 & 14.6421 & 1,240 & 1.28 & 15,900 & 15.5 & 116 & 48.1 & 103 \\
\hline T3-1b-35 & 1.9116 & 14.6978 & 1,080 & 1.53 & 13,900 & 32.4 & 113 & 38.2 & 87.7 \\
\hline T3-1b-20 & 2.0293 & 14.8129 & 1,150 & 1.29 & 14,800 & 22.6 & 118 & 39.7 & 93.9 \\
\hline T3-1c-35 & 2.0960 & 14.5894 & 1,200 & 1.61 & 15,000 & 35.5 & 114 & 37.9 & 98.1 \\
\hline T3-1c-20 & 2.4174 & 14.7447 & 1,440 & 1.63 & 18,400 & 29 & 137 & 46.0 & 114 \\
\hline T3-2-35 & 1.8990 & 14.7282 & 1,150 & 1.41 & 13,900 & 31.4 & 206 & 1.32 & 89.8 \\
\hline T3-2-20 & 2.1255 & 14.5286 & 1,260 & 0.878 & 15,600 & 35.1 & 233 & 1.40 & 100 \\
\hline T3-3-35 & 1.9538 & 14.6158 & 1,050 & 1.48 & 14,100 & 45.0 & 3.7 & 35.7 & 89.6 \\
\hline T3-3-20 & 2.3100 & 14.5261 & 1,300 & 1.70 & 17,600 & 17 & 8.3 & 41.0 & 105 \\
\hline T3-4-35 & 1.4855 & 14.6971 & 894 & 0.960 & 10,900 & 113 & 3.0 & 0.97 & 69.2 \\
\hline T3-4-20 & 2.1851 & 14.6996 & 1,290 & 1.20 & 15,400 & 47.0 & 3.9 & 1.32 & 102 \\
\hline T3-5-35 & 2.0900 & 14.5645 & 1,140 & 1.62 & 15,100 & 46.7 & 154 & 49.2 & 96.5 \\
\hline T3-5-20 & 2.1006 & 14.4504 & 1,160 & 1.36 & 15,500 & 15.5 & 157 & 47.6 & 97.5 \\
\hline T3-6-35 & 1.8776 & 14.7100 & 1,110 & 1.15 & 13,700 & 2.6 & 353 & 1.2 & 86.4 \\
\hline T3-6-20 & 2.2394 & 14.5784 & 1,390 & 0.989 & 17,500 & --- & 440 & 1.9 & 104 \\
\hline T3-7-35 & 1.5991 & 14.5299 & 940 & 1.32 & 11,900 & 2.2 & 3.4 & 33.4 & 77.1 \\
\hline T3-7-20 & 2.1413 & 14.5140 & 1,200 & 1.39 & 15,400 & 2.9 & 5.4 & 42.1 & 101 \\
\hline T3-8-35 & 1.9431 & 14.8338 & 1,150 & 1.24 & 13,800 & 2.5 & 4.3 & 1.23 & 90.9 \\
\hline T3-8-20 & 2.1305 & 14.6274 & 1,270 & 0.894 & 15,400 & 2.9 & 3.7 & 1.32 & 101 \\
\hline T3-9-35 & 1.8035 & 14.6740 & 1,100 & 1.35 & 13,000 & 2.4 & 3.5 & 1.1 & 86.4 \\
\hline T3-9-20 & 2.1095 & 14.3832 & 1,280 & 0.861 & 15,500 & 3.2 & 4.2 & 1.34 & 102 \\
\hline
\end{tabular}

Table A.4. IC Results for Task 3 Supernate

\begin{tabular}{ccccccccc}
\hline $\begin{array}{c}\text { Sample } \\
\text { ID }\end{array}$ & $\begin{array}{c}\text { Sample } \\
\text { Wt }(\mathrm{g})\end{array}$ & $\begin{array}{c}\mathrm{DIW} \mathrm{Wt} \\
(\mathrm{g})\end{array}$ & $\begin{array}{c}\mathrm{F} \\
(\mathrm{mg} / \mathrm{L})\end{array}$ & $\begin{array}{c}\mathrm{C}_{2} \mathrm{O}_{4} \\
(\mathrm{mg} / \mathrm{L})\end{array}$ & $\begin{array}{c}\mathrm{PO}_{4} \\
(\mathrm{mg} / \mathrm{L})\end{array}$ & $\begin{array}{c}\mathrm{SO}_{4} \\
(\mathrm{mg} / \mathrm{L})\end{array}$ & $\begin{array}{c}\mathrm{NO}_{3} \\
(\mathrm{mg} / \mathrm{L})\end{array}$ & $\begin{array}{c}\mathrm{NO}_{2} \\
(\mathrm{mg} / \mathrm{L})\end{array}$ \\
\hline T3-1a-35 & 1.9441 & 14.8330 & 83 & 19 & 113 & 332 & 6,450 & 1,420 \\
T3-1a-20 & 2.1873 & 14.6421 & 85 & 18 & 50 & 375 & 7,380 & 1,620 \\
T3-1b-35 & 1.9116 & 14.6978 & 83 & 18 & 105 & 364 & 6,440 & 1,420 \\
T3-1b-20 & 2.0293 & 14.8129 & 84 & 18 & 72 & 383 & 6,810 & 1,490 \\
T3-1c-35 & 2.0960 & 14.5894 & 90 & 19 & 118 & 370 & 6,980 & 1,540 \\
T3-1c-20 & 2.4174 & 14.7447 & 98 & 22 & 95 & 421 & 8,030 & 1,760 \\
T3-2-35 & 1.8990 & 14.7282 & $<3$ & 18 & 106 & 668 & 6,400 & 1,410 \\
T3-2-20 & 2.1255 & 14.5286 & $<3$ & 19 & 116 & 746 & 7,260 & 1,590 \\
T3-3-35 & 1.9538 & 14.6158 & 89 & $<4$ & 148 & 10 & 6,520 & 1,440 \\
T3-3-20 & 2.3100 & 14.5261 & 92 & $<4$ & 52 & 13 & 7,760 & 1,710 \\
T3-4-35 & 1.4855 & 14.6971 & $<3$ & $<4$ & 376 & 8 & 5,080 & 1,110 \\
T3-4-20 & 2.1851 & 14.6996 & $<3$ & $<4$ & 154 & 11 & 7,410 & 1,620 \\
T3-5-35 & 2.0900 & 14.5645 & 88 & $<4$ & 151 & 499 & 6,980 & 1,540 \\
T3-5-20 & 2.1006 & 14.4504 & 79 & $<4$ & 49 & 503 & 7,140 & 1,560 \\
T3-6-35 & 1.8776 & 14.7100 & $<3$ & $<4$ & 10 & 1,120 & 6,340 & 1,390 \\
T3-6-20 & 2.2394 & 14.5784 & $<3$ & $<4$ & 10 & 1,330 & 7,560 & 1,650 \\
T3-7-35 & 1.5991 & 14.5299 & 75 & 16 & 8 & 10 & 5,550 & 1,220 \\
T3-7-20 & 2.1413 & 14.5140 & 98 & 19 & 10 & 14 & 7,330 & 1,600 \\
T3-8-35 & 1.9431 & 14.8338 & $<3$ & 19 & 9 & 11 & 6,580 \\
T3-8-20 & 2.1305 & 14.6274 & $<3$ & 19 & 10 & 13 & 7,320 & 1,440 \\
T3-9-35 & 1.8035 & 14.6740 & $<3$ & $<4$ & 8 & 10 & 6,190 & 1,590 \\
T3-9-20 & 2.1095 & 14.3832 & $<3$ & $<4$ & 10 & 11 & 7,370 & 1,600 \\
\hline
\end{tabular}


Table A.5. ICP Results for Task 5 Test B Post-Caustic Wash Solutions Composition

\begin{tabular}{|c|c|c|c|c|c|c|c|}
\hline $\begin{array}{c}\text { Sample } \\
\text { ID }\end{array}$ & Wash \# & $\begin{array}{c}\text { Sample Wt } \\
\text { (g) }\end{array}$ & $\begin{array}{c}\text { DIW Wt } \\
(\mathrm{g})\end{array}$ & $\begin{array}{c}\mathrm{Al} \\
(\mathrm{mg} / \mathrm{L})\end{array}$ & $\begin{array}{c}\mathrm{Na} \\
(\mathrm{mg} / \mathrm{L})\end{array}$ & $\begin{array}{c}\mathrm{P} \\
(\mathrm{mg} / \mathrm{L})\end{array}$ & $\begin{array}{c}\mathrm{S} \\
(\mathrm{mg} / \mathrm{L})\end{array}$ \\
\hline B-4153-20 $0^{\circ} \mathrm{C}$ & supernate & 1.3946 & 10.0360 & 2,070 & 16,400 & 42.5 & 258 \\
\hline $\mathrm{B}-4153-25^{\circ} \mathrm{C}$ & supernate & 2.2456 & 15.0487 & 2,220 & 18,800 & 68.1 & 265 \\
\hline $\mathrm{B}-4153-35^{\circ} \mathrm{C}$ & supernate & 1.4634 & 14.3978 & 1,490 & 12,600 & 60.6 & 185 \\
\hline $\mathrm{B}-4154-20^{\circ} \mathrm{C}$ & supernate & 1.3441 & 10.0310 & 2,030 & 16,000 & 41.0 & 255 \\
\hline $\mathrm{B}-4154-25^{\circ} \mathrm{C}$ & supernate & 2.2520 & 15.0916 & 2,250 & 18,900 & 68.1 & 266 \\
\hline $\mathrm{B}-4154-35^{\circ} \mathrm{C}$ & supernate & 1.6064 & 14.6050 & 1,630 & 13,800 & 64.4 & 208 \\
\hline $\mathrm{B}-4223-20^{\circ} \mathrm{C}$ & 1 & 1.3278 & 10.0397 & 2,020 & 16,000 & 40.6 & 252 \\
\hline $\mathrm{B}-4223-25^{\circ} \mathrm{C}$ & 1 & 2.1873 & 15.0821 & 2,220 & 18,600 & 65.1 & 266 \\
\hline $\mathrm{B}-4223-35^{\circ} \mathrm{C}$ & 1 & 1.6984 & 14.8256 & 1,680 & 14,300 & 68.5 & 217 \\
\hline $\mathrm{B}-4225-20^{\circ} \mathrm{C}$ & 3 & 1.3149 & 10.1141 & 1,920 & 15,100 & 39.8 & 240 \\
\hline $\mathrm{B}-4225-25^{\circ} \mathrm{C}$ & 3 & 2.6304 & 15.1703 & 2,490 & 20,900 & 75.8 & 295 \\
\hline B- $4225-35^{\circ} \mathrm{C}$ & 3 & 1.6611 & 14.7887 & 1,630 & 13,800 & 63.5 & 207 \\
\hline $\mathrm{B}-4227-20^{\circ} \mathrm{C}$ & 5 & 1.4020 & 10.0191 & 2,020 & 16,100 & 44.5 & 252 \\
\hline B- $4227-25^{\circ} \mathrm{C}$ & 5 & 2.3055 & 15.1890 & 2,180 & 18,200 & 73.4 & 261 \\
\hline B- $4227-35^{\circ} \mathrm{C}$ & 5 & 1.6452 & 14.9335 & 1,600 & 13,300 & 62.5 & 202 \\
\hline B- $4229-20^{\circ} \mathrm{C}$ & 7 & 1.2877 & 10.0189 & 1,800 & 14,300 & 43.4 & 224 \\
\hline B- $4229-25^{\circ} \mathrm{C}$ & 7 & 2.2096 & 15.1316 & 2,000 & 16,800 & 72.1 & 240 \\
\hline B- $4229-35^{\circ} \mathrm{C}$ & 7 & 1.6685 & 14.8253 & 1,550 & 13,000 & 65.0 & 200 \\
\hline $\mathrm{B}-4231-20^{\circ} \mathrm{C}$ & 9 & 1.2212 & 10.0932 & 1,610 & 12,900 & 42.0 & 198 \\
\hline B- $4231-25^{\circ} \mathrm{C}$ & 9 & 2.0699 & 15.1061 & 1,760 & 14,700 & 68.6 & 209 \\
\hline $\mathrm{B}-4231-35^{\circ} \mathrm{C}$ & 9 & 1.6151 & 14.7775 & 1,430 & 12,100 & 66.6 & 182 \\
\hline B- $4234-20^{\circ} \mathrm{C}$ & 12 & 1.2234 & 10.0356 & 1,430 & 11,400 & 54.9 & 177 \\
\hline $\mathrm{B}-4234-25^{\circ} \mathrm{C}$ & 12 & 2.2353 & 15.0780 & 1,710 & 14,300 & 92.7 & 202 \\
\hline $\mathrm{B}-4234-35^{\circ} \mathrm{C}$ & 12 & 1.4997 & 14.6018 & 1,180 & 9,990 & 65.7 & 151 \\
\hline $\mathrm{B}-4237-20^{\circ} \mathrm{C}$ & 15 & 1.1844 & 10.0864 & 1,200 & 9,600 & 69.9 & 146 \\
\hline $\mathrm{B}-4237-25^{\circ} \mathrm{C}$ & 15 & 1.7792 & 15.0304 & 1,180 & 9,840 & 72.0 & 140 \\
\hline B- $4237-35^{\circ} \mathrm{C}$ & 15 & 1.6064 & 14.4460 & 1,120 & 9,510 & 70.4 & 140 \\
\hline B- $4240-20^{\circ} \mathrm{C}$ & 18 & 0.9912 & 10.1280 & 873 & 7,030 & 54.5 & 104 \\
\hline B- $4240-25^{\circ} \mathrm{C}$ & 18 & 1.8278 & 15.0411 & 1,040 & 8,800 & 70.2 & 124 \\
\hline $\mathrm{B}-4240-35^{\circ} \mathrm{C}$ & 18 & 1.4759 & 14.6444 & 863 & 7,350 & 58.3 & 106 \\
\hline
\end{tabular}


Table A.6. IC Results for Task 5 Test B Post-Caustic Wash Solutions Composition

\begin{tabular}{|c|c|c|c|c|c|c|c|c|}
\hline $\begin{array}{c}\text { Sample } \\
\text { ID }\end{array}$ & Wash \# & $\begin{array}{l}\text { Sample } \\
\mathrm{Wt}(\mathrm{g})\end{array}$ & $\begin{array}{c}\text { DIW Wt } \\
(\mathrm{g})\end{array}$ & $\begin{array}{c}\mathrm{C}_{2} \mathrm{O}_{4} \\
(\mathrm{mg} / \mathrm{L})\end{array}$ & $\begin{array}{c}\mathrm{PO}_{4} \\
(\mathrm{mg} / \mathrm{L})\end{array}$ & $\begin{array}{c}\mathrm{SO}_{4} \\
(\mathrm{mg} / \mathrm{L})\end{array}$ & $\begin{array}{c}\mathrm{NO}_{3} \\
(\mathrm{mg} / \mathrm{L})\end{array}$ & $\begin{array}{c}\mathrm{NO}_{2} \\
(\mathrm{mg} / \mathrm{L})\end{array}$ \\
\hline B-4153-20 $0^{\circ} \mathrm{C}$ & supernate & 1.3946 & 10.0360 & 9 & 142 & 788 & 4,570 & 1,100 \\
\hline $\mathrm{B}-4153-25^{\circ} \mathrm{C}$ & supernate & 2.2456 & 15.0487 & 8 & 217 & 832 & 4,850 & 1,160 \\
\hline $\mathrm{B}-4153-35^{\circ} \mathrm{C}$ & supernate & 1.4634 & 14.3978 & 6 & 202 & 588 & 3,430 & 812 \\
\hline B- $4154-20^{\circ} \mathrm{C}$ & supernate & 1.3441 & 10.0310 & 7 & 134 & 750 & 4,380 & 1,050 \\
\hline $\mathrm{B}-4154-25^{\circ} \mathrm{C}$ & supernate & 2.2520 & 15.0916 & 7 & 211 & 832 & 4,840 & 1,160 \\
\hline $\mathrm{B}-4154-35^{\circ} \mathrm{C}$ & supernate & 1.6064 & 14.6050 & 6 & 206 & 632 & 3,700 & 875 \\
\hline $\mathrm{B}-4223-20^{\circ} \mathrm{C}$ & 1 & 1.3278 & 10.0397 & 7 & 133 & 768 & 4,470 & 1,070 \\
\hline B- $4223-25^{\circ} \mathrm{C}$ & 1 & 2.1873 & 15.0821 & 7 & 202 & 814 & 4,740 & 1,140 \\
\hline B- $4223-35^{\circ} \mathrm{C}$ & 1 & 1.6984 & 14.8256 & 6 & 223 & 659 & 3,860 & 912 \\
\hline $\mathrm{B}-4225-20^{\circ} \mathrm{C}$ & 3 & 1.3149 & 10.1141 & 7 & 128 & 714 & 4,160 & 999 \\
\hline $\mathrm{B}-4225-25^{\circ} \mathrm{C}$ & 3 & 2.6304 & 15.1703 & 8 & 236 & 937 & 5,420 & 1,300 \\
\hline $\mathrm{B}-4225-35^{\circ} \mathrm{C}$ & 3 & 1.6611 & 14.7887 & 6 & 203 & 630 & 3,690 & 872 \\
\hline $\mathrm{B}-4227-20^{\circ} \mathrm{C}$ & 5 & 1.4020 & 10.0191 & 8 & 141 & 752 & 4,380 & 1,050 \\
\hline $\mathrm{B}-4227-25^{\circ} \mathrm{C}$ & 5 & 2.3055 & 15.1890 & 8 & 228 & 813 & 4,740 & 1,140 \\
\hline $\mathrm{B}-4227-35^{\circ} \mathrm{C}$ & 5 & 1.6452 & 14.9335 & 7 & 200 & 609 & 3580 & 847 \\
\hline B- $4229-20^{\circ} \mathrm{C}$ & 7 & 1.2877 & 10.0189 & 11 & 137 & 662 & 3,860 & 930 \\
\hline $\mathrm{B}-4229-25^{\circ} \mathrm{C}$ & 7 & 2.2096 & 15.1316 & 11 & 225 & 747 & 4,370 & 1,050 \\
\hline $\mathrm{B}-4229-35^{\circ} \mathrm{C}$ & 7 & 1.6685 & 14.8253 & 10 & 208 & 595 & 3,480 & 822 \\
\hline $\mathrm{B}-4231-20^{\circ} \mathrm{C}$ & 9 & 1.2212 & 10.0932 & 17 & 140 & 586 & 3,410 & 818 \\
\hline $\mathrm{B}-4231-25^{\circ} \mathrm{C}$ & 9 & 2.0699 & 15.1061 & 18 & 221 & 660 & 3,860 & 929 \\
\hline B- $4231-35^{\circ} \mathrm{C}$ & 9 & 1.6151 & 14.7775 & 15 & 214 & 542 & 3,160 & 747 \\
\hline $\mathrm{B}-4234-20^{\circ} \mathrm{C}$ & 12 & 1.2234 & 10.0356 & 25 & 178 & 522 & 3,040 & 729 \\
\hline B- $4234-25^{\circ} \mathrm{C}$ & 12 & 2.2353 & 15.0780 & 28 & 292 & 622 & 3,650 & 874 \\
\hline B- $4234-35^{\circ} \mathrm{C}$ & 12 & 1.4997 & 14.6018 & 24 & 210 & 446 & 2,590 & 612 \\
\hline B- $4237-20^{\circ} \mathrm{C}$ & 15 & 1.1844 & 10.0864 & 40 & 231 & 433 & 2,520 & 604 \\
\hline B- $4237-25^{\circ} \mathrm{C}$ & 15 & 1.7792 & 15.0304 & 41 & 232 & 438 & 2,550 & 610 \\
\hline $\mathrm{B}-4237-35^{\circ} \mathrm{C}$ & 15 & 1.6064 & 14.4460 & 49 & 221 & 417 & 2,420 & 569 \\
\hline $\mathrm{B}-4240-20^{\circ} \mathrm{C}$ & 18 & 0.9912 & 10.1280 & 59 & 178 & 309 & 1,770 & 423 \\
\hline B- $4240-25^{\circ} \mathrm{C}$ & 18 & 1.8278 & 15.0411 & 75 & 222 & 384 & 2,220 & 530 \\
\hline $\mathrm{B}-4240-35^{\circ} \mathrm{C}$ & 18 & 1.4759 & 14.6444 & 76 & 187 & 324 & 1,870 & 438 \\
\hline
\end{tabular}


Table A.7. Density Results for Task 5 Test B Post-Caustic Wash Solutions Composition

\begin{tabular}{lccccc}
\hline Sample ID & Wash \# & $\begin{array}{c}\text { Density } \\
(\mathrm{g} / \mathrm{mL})\end{array}$ & $\begin{array}{c}\text { Sample } \\
\text { ID }\end{array}$ & Wash \# & $\begin{array}{c}\text { Density } \\
(\mathrm{g} / \mathrm{mL})\end{array}$ \\
\hline $4153-20^{\circ} \mathrm{C}$ & supernate & 1.329 & $4229-20^{\circ} \mathrm{C}$ & 7 & 1.300 \\
$4153-25^{\circ} \mathrm{C}$ & supernate & 1.327 & $4229-25^{\circ} \mathrm{C}$ & 7 & 1.300 \\
$4153-35^{\circ} \mathrm{C}$ & supernate & 1.323 & $4229-35^{\circ} \mathrm{C}$ & 7 & 1.294 \\
& & & & & \\
$4154-20^{\circ} \mathrm{C}$ & supernate & 1.329 & $4231-20^{\circ} \mathrm{C}$ & 9 & 1.281 \\
$4154-25^{\circ} \mathrm{C}$ & supernate & 1.328 & $4231-25^{\circ} \mathrm{C}$ & 9 & 1.280 \\
$4154-35^{\circ} \mathrm{C}$ & supernate & 1.323 & $4231-35^{\circ} \mathrm{C}$ & 9 & 1.277 \\
& & & & & \\
$4223-20^{\circ} \mathrm{C}$ & 1 & 1.330 & $4234-20^{\circ} \mathrm{C}$ & 12 & 1.248 \\
$4223-25^{\circ} \mathrm{C}$ & 1 & 1.328 & $4234-25^{\circ} \mathrm{C}$ & 12 & 1.244 \\
$4223-35^{\circ} \mathrm{C}$ & 1 & 1.324 & $4234-35^{\circ} \mathrm{C}$ & 12 & 1.240 \\
& & & & & \\
$4225-20^{\circ} \mathrm{C}$ & 3 & 1.320 & $4237-20^{\circ} \mathrm{C}$ & 15 & 1.212 \\
$4225-25^{\circ} \mathrm{C}$ & 3 & 1.319 & $4237-25^{\circ} \mathrm{C}$ & 15 & 1.209 \\
$4225-35^{\circ} \mathrm{C}$ & 3 & 1.314 & $4237-35^{\circ} \mathrm{C}$ & 15 & 1.206 \\
& & & & & \\
$4227-20^{\circ} \mathrm{C}$ & 5 & 1.315 & $4240-20^{\circ} \mathrm{C}$ & 18 & 1.178 \\
$4227-25^{\circ} \mathrm{C}$ & 5 & 1.311 & $4240-25^{\circ} \mathrm{C}$ & 18 & 1.177 \\
$4227-35^{\circ} \mathrm{C}$ & 5 & 1.307 & $4240-35^{\circ} \mathrm{C}$ & 18 & 1.172 \\
\hline
\end{tabular}

Table A.8. ICP Results for Task 6 Supernate

\begin{tabular}{ccccccc}
\hline $\begin{array}{c}\text { Sample } \\
\text { ID }\end{array}$ & $\begin{array}{c}\text { Sample } \\
\text { Wt }(\mathrm{g})\end{array}$ & $\begin{array}{c}\text { DIW Wt } \\
(\mathrm{g})\end{array}$ & $\begin{array}{c}\mathrm{Al} \\
(\mathrm{mg} / \mathrm{L})\end{array}$ & $\begin{array}{c}\mathrm{Na} \\
(\mathrm{mg} / \mathrm{L})\end{array}$ & $\begin{array}{c}\mathrm{P} \\
(\mathrm{mg} / \mathrm{L})\end{array}$ & $\begin{array}{c}\mathrm{S} \\
(\mathrm{mg} / \mathrm{L})\end{array}$ \\
\hline Blend 1 & 1.8414 & 14.9795 & 839 & 10,200 & 112 & 306 \\
Blend 2 & 2.1074 & 14.9407 & 1,920 & 15,900 & 64.5 & 237 \\
Blend 3 & 1.9291 & 14.7809 & 1,340 & 11,200 & 56.9 & 162 \\
Blend 4 & 1.7653 & 14.9762 & 972 & 8,160 & 49.9 & 117 \\
Blend 5 & 2.0636 & 15.1189 & 1,880 & 15,600 & 67.5 & 226 \\
\hline
\end{tabular}

Table A.9. IC Results for Task 6 Supernate

\begin{tabular}{cccccccc}
\hline $\begin{array}{c}\text { Sample } \\
\text { ID }\end{array}$ & $\begin{array}{c}\text { Sample } \\
\mathrm{Wt}(\mathrm{g})\end{array}$ & $\begin{array}{c}\mathrm{DIW} \text { Wt } \\
(\mathrm{g})\end{array}$ & $\begin{array}{c}\mathrm{C}_{2} \mathrm{O}_{4} \\
(\mathrm{mg} / \mathrm{L})\end{array}$ & $\begin{array}{c}\mathrm{PO}_{4} \\
(\mathrm{mg} / \mathrm{L})\end{array}$ & $\begin{array}{c}\mathrm{SO}_{4} \\
(\mathrm{mg} / \mathrm{L})\end{array}$ & $\begin{array}{c}\mathrm{NO}_{3} \\
(\mathrm{mg} / \mathrm{L})\end{array}$ & $\begin{array}{c}\mathrm{NO}_{2} \\
(\mathrm{mg} / \mathrm{L})\end{array}$ \\
\hline Blend 1 & 1.8414 & 14.9795 & 75 & 336 & 903 & 5,260 & 1,270 \\
Blend 2 & 2.1074 & 14.9407 & 15 & 210 & 736 & 4,220 & 1,020 \\
Blend 3 & 1.9291 & 14.7809 & 48 & 172 & 487 & 2,750 & 653 \\
Blend 4 & 1.7653 & 14.9762 & 90 & 149 & 347 & 1,940 & 465 \\
Blend 5 & 2.0636 & 15.1189 & 19 & 208 & 676 & 3,880 & 931 \\
\hline
\end{tabular}


Table A.10. Particle Size Analysis Statistics for Sample \# 2341

\begin{tabular}{|c|c|c|c|}
\hline Crystal No. & Area, $\mu \mathrm{m}^{2}$ & $\begin{array}{c}\text { Max Length, } \\
\mu \mathrm{m}\end{array}$ & $\begin{array}{c}\text { Max Width, } \\
\mu \mathrm{m}\end{array}$ \\
\hline 1 & 39,709 & 1,326 & 30.9 \\
\hline 2 & 26,843 & 1,275 & 30.7 \\
\hline 3 & 64,265 & 924.3 & 71.5 \\
\hline 4 & 29,013 & 996.4 & 33.1 \\
\hline 5 & 30,413 & 1,141 & 27.3 \\
\hline 6 & 43,489 & 1,344 & 35.9 \\
\hline 7 & 61,072 & 1,213 & 52.0 \\
\hline 8 & 30,857 & 738.0 & 51.3 \\
\hline 9 & 58,964 & 1,570 & 39.3 \\
\hline 10 & 121,290 & 905.0 & 148 \\
\hline 11 & 194,030 & 1,747 & 143 \\
\hline 12 & 15,177 & 832.6 & 20.6 \\
\hline 13 & $2,287.8$ & 101.6 & 45.5 \\
\hline 14 & $9,646.9$ & 393.4 & 31.4 \\
\hline 15 & 44,843 & 549.0 & 95.2 \\
\hline 16 & 51,087 & 1,738 & 35.0 \\
\hline 17 & 14,633 & 431.3 & 42.0 \\
\hline 18 & 16,300 & 669.0 & 32.0 \\
\hline Mean & 47,440 & 994.1 & 53.6 \\
\hline Min & 2,288 & 101.6 & 20.6 \\
\hline Max & 194,030 & 1,747 & 148 \\
\hline Sum & 853,920 & 17,893 & 965 \\
\hline Std. Dev. & 45,712 & 467.4 & 37.8 \\
\hline Variance & $2,089,577,158$ & 218,491 & 1430 \\
\hline Skew & 2.281 & -0.069 & 1.860 \\
\hline Excess & 6.015 & -0.639 & 2.574 \\
\hline Var. Coeff. & 96 & 47 & 71 \\
\hline Obj. Count & 18 & - & - \\
\hline Img. Area & $19,091,308$ & - & - \\
\hline Total Obj. Count & 20 & - & - \\
\hline Total Img. Area & $38,182,615$ & - & - \\
\hline
\end{tabular}


Table A.11. Particle Size Analysis Statistics for Sample \# 2349

\begin{tabular}{|c|c|c|c|}
\hline Crystal No. & Area, $\mu \mathrm{m}^{2}$ & Max Length, $\mu \mathrm{m}$ & Max Width, $\mu \mathrm{m}$ \\
\hline 1 & $1,036,690$ & 4,044 & 314 \\
\hline 2 & 118,719 & 1,424 & 90 \\
\hline 3 & 133,681 & 673 & 275 \\
\hline 4 & 188,341 & 715 & 480 \\
\hline 5 & 688,911 & 2,595 & 273 \\
\hline 6 & 484,776 & 3,138 & 256 \\
\hline 7 & 329,057 & 1,300 & 314 \\
\hline 8 & $2,206,430$ & 4,204 & 656 \\
\hline 9 & 805,433 & 2,827 & 344 \\
\hline 10 & 395,698 & 2,018 & 203 \\
\hline 11 & 80,973 & 901 & 104 \\
\hline 12 & 154,128 & 804 & 220 \\
\hline 13 & 235,374 & 1,024 & 302 \\
\hline 14 & 638,549 & 1,949 & 417 \\
\hline 15 & 107,937 & 1,288 & 99 \\
\hline 16 & 173,975 & 2,663 & 71 \\
\hline 17 & $1,091,160$ & 2,088 & 575 \\
\hline 18 & 893,284 & 2,332 & 496 \\
\hline 19 & 512,003 & 3,448 & 166 \\
\hline 20 & 448,552 & 1,431 & 356 \\
\hline Mean & 536,183 & 2,043 & 301 \\
\hline Min & 80,973 & 673 & 71 \\
\hline Max & $2,206,430$ & 4,204 & 656 \\
\hline Sum & $10,723,664$ & 40,869 & 6,011 \\
\hline Std. Dev. & 506,335 & 1,092 & 163 \\
\hline Variance & $256,374,682,000$ & 1191920 & 26,559 \\
\hline Skew & 2 & 1 & 1 \\
\hline Excess & 5 & -1 & 0 \\
\hline Var. Coeff. & 94 & 53 & 54 \\
\hline Obj. Count & 8 & - & - \\
\hline Img. Area & $19,091,308$ & - & - \\
\hline Total Obj. Count & 20 & - & - \\
\hline Total Img. Area & $76,365,230$ & - & - \\
\hline
\end{tabular}


Table A.12. Particle Size Analysis Statistics for Sample \# 2363

\begin{tabular}{cccc}
\hline Crystal No. & Area, $\mu \mathrm{m}^{2}$ & Max Length, $\mu \mathrm{m}$ & Max Width, $\mu \mathrm{m}$ \\
\hline 1 & 498,504 & 1,065 & 537 \\
2 & 242,586 & 1,439 & 183 \\
3 & 276,394 & 1,242 & 243 \\
4 & 236,186 & 2,183 & 143 \\
5 & 429,159 & 2,469 & 215 \\
6 & 543,611 & 1,420 & 502 \\
7 & 110,800 & 877 & 146 \\
8 & 359,130 & 1,261 & 373 \\
9 & 239,529 & 1,095 & 241 \\
10 & 184,379 & 801 & 281 \\
11 & 357,441 & 1,687 & 233 \\
12 & 93,673 & 668 & 170 \\
Mean & 297,616 & 1,351 & 272 \\
Min & 93,673 & 668 & 143 \\
Max & 543,611 & 2,469 & 537 \\
Sum & $3,571,392$ & 16,207 & 3,266 \\
\hline Std. Dev. & 143,171 & 542 & 132 \\
\hline Variance & $20,497,989,504$ & 293,402 & 17,346 \\
Skew & 0 & 1 & 1 \\
Excess & -1 & 0 & 0 \\
Var. Coeff. & 48 & 40 & 48 \\
Obj. Count & 12 & - & - \\
\hline Img. Area & $19,091,308$ & - & - \\
Total Obj. Count & 33 & - & - \\
Total Img. Area & $38,182,615$ & - & \\
\hline & & & - \\
\hline
\end{tabular}


Table A.13. Particle Size Analysis Statistics for Sample \# 2369

\begin{tabular}{|c|c|c|c|}
\hline Crystal No. & Area, $\mu \mathrm{m}^{2}$ & Max Length, $\mu \mathrm{m}$ & Max Width, $\mu \mathrm{m}$ \\
\hline 1 & 10,788 & 389 & 30 \\
\hline 2 & 205,169 & 1,162 & 252 \\
\hline 3 & 101,625 & 1,410 & 81 \\
\hline 4 & 93,851 & 880 & 124 \\
\hline 5 & 339,532 & 2,027 & 176 \\
\hline 6 & 425,482 & 1,982 & 268 \\
\hline 7 & 1,157 & 83 & 45 \\
\hline 8 & 11,795 & 347 & 44 \\
\hline 9 & 144,725 & 994 & 182 \\
\hline 10 & 235,350 & 1,833 & 152 \\
\hline 11 & 25,156 & 359 & 75 \\
\hline 12 & 88,001 & 941 & 108 \\
\hline 13 & 43,204 & 551 & 97 \\
\hline 14 & 120,611 & 1,165 & 110 \\
\hline 15 & 35,127 & 261 & 136 \\
\hline 16 & 118,232 & 1,329 & 135 \\
\hline 17 & 86,454 & 735 & 172 \\
\hline 18 & 143,424 & 1,276 & 121 \\
\hline 19 & 20,013 & 250 & 95 \\
\hline 20 & 250,255 & 1,471 & 187 \\
\hline 21 & 157,966 & 530 & 426 \\
\hline Mean & 126,568 & 951 & 144 \\
\hline Min & 1,157 & 83 & 30 \\
\hline Max & 425,482 & 2,027 & 426 \\
\hline Sum & $2,657,918$ & 19,975 & 3,016 \\
\hline Std. Dev. & 112,641 & 590 & 90 \\
\hline Variance & $12,688,102,534$ & 348,099 & 8,062 \\
\hline Skew & 1 & 0 & 2 \\
\hline Excess & 1 & -1 & 4 \\
\hline Var. Coeff. & 89 & 62 & 63 \\
\hline Obj. Count & 21 & - & - \\
\hline Img. Area & $19,091,308$ & - & - \\
\hline Total Obj. Count & 33 & - & - \\
\hline Total Img. Area & $38,182,615$ & - & - \\
\hline
\end{tabular}


Table A.14. Particle Size Analysis Statistics for Sample \# T3-1a

\begin{tabular}{|c|c|c|c|}
\hline Crystal No. & Area, $\mu \mathrm{m}^{2}$ & Max Length, $\mu \mathrm{m}$ & Max Width, $\mu \mathrm{m}$ \\
\hline 1 & 142,427 & 523 & 364 \\
\hline 2 & 46,147 & 340 & 243 \\
\hline 3 & 258,589 & 708 & 505 \\
\hline 4 & 203,049 & 672 & 427 \\
\hline 5 & 379,026 & 986 & 530 \\
\hline 6 & 275,267 & 716 & 593 \\
\hline 7 & 270,194 & 783 & 497 \\
\hline 8 & 253,255 & 689 & 509 \\
\hline 9 & 95,054 & 402 & 335 \\
\hline 10 & 154,059 & 561 & 418 \\
\hline 11 & 27,421 & 207 & 180 \\
\hline 12 & 17,593 & 209 & 195 \\
\hline 13 & 86,955 & 386 & 298 \\
\hline 14 & 96,563 & 423 & 283 \\
\hline 15 & 201,314 & 625 & 441 \\
\hline 16 & 42,315 & 310 & 202 \\
\hline 17 & 10,101 & 148 & 95 \\
\hline 18 & 11,213 & 137 & 112 \\
\hline 19 & 65,894 & 320 & 269 \\
\hline 20 & 94,311 & 398 & 346 \\
\hline 21 & 369,832 & 851 & 785 \\
\hline 22 & 26,030 & 210 & 174 \\
\hline 23 & 8,776 & 126 & 97 \\
\hline 24 & $1,240,400$ & 1,700 & 1,055 \\
\hline 25 & 335,305 & 838 & 687 \\
\hline 26 & 383,128 & 883 & 698 \\
\hline 27 & 187,736 & 627 & 466 \\
\hline 28 & 355,909 & 786 & 678 \\
\hline Mean & 201,352 & 556 & 410 \\
\hline Min & 8,776 & 126 & 95 \\
\hline Max & $1,240,400$ & 1,700 & 1,055 \\
\hline Sum & $5,637,863$ & 15,565 & 11,482 \\
\hline Std. Dev. & 240,034 & 339 & 231 \\
\hline Variance & $57,616,500,370$ & 115,173 & 53,302 \\
\hline Skew & 3 & 1 & 1 \\
\hline Excess & 13 & 3 & 1 \\
\hline Var. Coeff. & 119 & 61 & 56 \\
\hline Obj. Count & 28 & - & - \\
\hline Img. Area & $19,091,307.52$ & - & - \\
\hline Total Obj. Count & 28 & - & - \\
\hline Total Img. Area & $57,273,922.57$ & - & - \\
\hline
\end{tabular}


Table A.15. Particle Size Analysis Statistics for Sample \# T3-1b

\begin{tabular}{cccc}
\hline Crystal No. & Area, $\mu \mathrm{m}^{2}$ & Max Length, $\mu \mathrm{m}$ & Max Width, $\mu \mathrm{m}$ \\
\hline 1 & 618,588 & 984 & 818 \\
2 & 4,134 & 98 & 60 \\
3 & 257,220 & 873 & 493 \\
Mean & 293,314 & 652 & 457 \\
Min & 4,134 & 98 & 60 \\
Max & 618,588 & 984 & 818 \\
Sum & 879,942 & 1,955 & 1,371 \\
Std. Dev. & 308,813 & 483 & 380 \\
Variance & $95,365,214,697$ & 233,182 & 144,691 \\
Skew & 1 & -2 & 0 \\
\hline Var. Coeff. & $32,512,997$ & 35,789 & 31,668 \\
Obj. Count & 3 & - & - \\
\hline
\end{tabular}

Table A.16. Particle Size Analysis Statistics for Sample \# T3-1c

\begin{tabular}{|c|c|c|c|}
\hline Crystal No. & Area, $\mu \mathrm{m}^{2}$ & Max Length, $\mu \mathrm{m}$ & Max Width, $\mu \mathrm{m}$ \\
\hline 1 & 571,708 & 954 & 867 \\
\hline 2 & 755,779 & 1,416 & 1,023 \\
\hline 3 & 608,736 & 1,119 & 771 \\
\hline 4 & 284,476 & 834 & 558 \\
\hline 5 & 664,337 & 1,372 & 900 \\
\hline 6 & 165,977 & 629 & 479 \\
\hline 7 & $1,876,168$ & 2,610 & 1,385 \\
\hline 8 & 636,772 & 1,160 & 963 \\
\hline 9 & 32,220 & 280 & 174 \\
\hline 10 & 35,091 & 279 & 201 \\
\hline 11 & $1,137,143$ & 1,455 & 1,092 \\
\hline 12 & 538,023 & 1,161 & 729 \\
\hline 13 & 145,457 & 656 & 397 \\
\hline 14 & 196,143 & 807 & 436 \\
\hline Mean & 546,288 & 1,052 & 712 \\
\hline Min & 32,220 & 279 & 174 \\
\hline Max & $1,876,168$ & 2,610 & 1,385 \\
\hline Sum & $7,648,030$ & 14,731 & 9,975 \\
\hline Std. Dev. & 496,941 & 588 & 354 \\
\hline Variance & $246,950,088,862$ & 346,313 & 125,029 \\
\hline Skew & 2 & 1 & 0 \\
\hline Excess & 3 & 3 & -1 \\
\hline Var. Coeff. & 91 & 56 & 50 \\
\hline Obj. Count & 14 & - & - \\
\hline Img. Area & $2,065,067$ & - & - \\
\hline
\end{tabular}

A.16 
Table A.17. Particle Size Analysis Statistics for Sample \# T3-3

\begin{tabular}{|c|c|c|c|}
\hline Crystal No. & Area, $\mu \mathrm{m}^{2}$ & Max Length, $\mu \mathrm{m}$ & Max Width, $\mu \mathrm{m}$ \\
\hline 1 & 215,732 & 583 & 523 \\
\hline 2 & 15,238 & 170 & 141 \\
\hline 3 & 90,927 & 439 & 298 \\
\hline 4 & 8,636 & 138 & 78 \\
\hline 5 & 4,340 & 89 & 63 \\
\hline 6 & 2,351 & 64 & 53 \\
\hline 7 & 4,006 & 86 & 69 \\
\hline 8 & 3,401 & 76 & 67 \\
\hline 9 & 6,501 & 106 & 89 \\
\hline 10 & 168,024 & 627 & 375 \\
\hline 11 & 2,416 & 64 & 55 \\
\hline 12 & 4,243 & 110 & 56 \\
\hline 13 & 3,460 & 94 & 59 \\
\hline 14 & 296,814 & 760 & 538 \\
\hline 15 & 168,648 & 601 & 417 \\
\hline 16 & 206,653 & 588 & 504 \\
\hline 17 & 39,255 & 267 & 212 \\
\hline 18 & 830,846 & 1,429 & 1,038 \\
\hline 19 & 140,541 & 552 & 344 \\
\hline 20 & 5,705 & 95 & 98 \\
\hline 21 & 209,325 & 561 & 524 \\
\hline 22 & 334,094 & 875 & 533 \\
\hline 23 & 142,545 & 491 & 419 \\
\hline 24 & 356,291 & 815 & 621 \\
\hline 25 & 123,341 & 431 & 399 \\
\hline 26 & 257,780 & 755 & 520 \\
\hline 27 & 4,723 & 90 & 74 \\
\hline 28 & 2,503 & 70 & 47 \\
\hline 29 & 2,460 & 63 & 62 \\
\hline 30 & 1,400 & 41 & 41 \\
\hline 31 & 1,699 & 46 & 46 \\
\hline 32 & 751 & 30 & 30 \\
\hline 33 & 870 & 33 & 33 \\
\hline 34 & 1,400 & 41 & 41 \\
\hline 35 & 2,445 & 56 & 56 \\
\hline 36 & 1,243 & 40 & 40 \\
\hline 37 & 472 & 24 & 24 \\
\hline 38 & 315 & 19 & 19 \\
\hline Mean & 96,352 & 301 & 227 \\
\hline Min & 315 & 19 & 19 \\
\hline $\operatorname{Max}$ & 830,846 & 1,429 & 1,038 \\
\hline Sum & $3,661,394$ & 11,422 & 8,607 \\
\hline Std. Dev. & 163,243 & 332 & 241 \\
\hline Variance & $26,648,164,956$ & 110,420 & 58,276 \\
\hline Skew & 3 & 1 & 1 \\
\hline Excess & 10 & 2 & 2 \\
\hline
\end{tabular}

A. 17 
Table A.17. Particle Size Analysis Statistics for Sample \# T3-3

\begin{tabular}{cccc}
\hline Crystal No. & Area, $\mu \mathrm{m}^{2}$ & Max Length, $\mu \mathrm{m}$ & Max Width, $\mu \mathrm{m}$ \\
\hline Var. Coeff. & 169 & 111 & 107 \\
Obj. Count & 38 & - & - \\
Img. Area & $2,065,067$ & - & - \\
Total Obj. Count & 2,394 & - & - \\
Total Img. Area & $27,380,421$ & - & - \\
\hline
\end{tabular}

Table A.18. Particle Size Analysis Statistics for Sample \# T3-4

\begin{tabular}{|c|c|c|c|}
\hline Crystal No. & Area, $\mu \mathrm{m}^{2}$ & Max Length, $\mu \mathrm{m}$ & Max Width, $\mu \mathrm{m}$ \\
\hline 1 & 10,212 & 630 & 17 \\
\hline 2 & 7,488 & 333 & 27 \\
\hline 3 & 18,494 & 503 & 47 \\
\hline 4 & 37,108 & 895 & 42 \\
\hline 5 & 16,430 & 651 & 29 \\
\hline 6 & 28,884 & 840 & 48 \\
\hline 7 & 13,430 & 486 & 29 \\
\hline 8 & 20,914 & 667 & 37 \\
\hline 9 & 28,289 & 976 & 33 \\
\hline 10 & 10,680 & 490 & 26 \\
\hline 11 & 7,544 & 325 & 31 \\
\hline 12 & 21,606 & 806 & 40 \\
\hline 13 & 8,503 & 393 & 24 \\
\hline 14 & 6,839 & 247 & 29 \\
\hline 15 & 16,178 & 584 & 42 \\
\hline 16 & 7,185 & 336 & 27 \\
\hline 17 & 36,720 & 1,153 & 54 \\
\hline 18 & 49,274 & 1,393 & 41 \\
\hline 19 & 2,300 & 118 & 25 \\
\hline 20 & 28,847 & 1,025 & 33 \\
\hline 21 & 21,238 & 510 & 51 \\
\hline 22 & 49,881 & 1,285 & 52 \\
\hline 23 & 4,941 & 288 & 22 \\
\hline 24 & 9,780 & 540 & 22 \\
\hline 25 & 20,687 & 775 & 39 \\
\hline 26 & 11,063 & 345 & 53 \\
\hline 27 & 11,048 & 454 & 28 \\
\hline 28 & 5,905 & 312 & 20 \\
\hline 29 & 27,472 & 986 & 36 \\
\hline 30 & 3,404 & 178 & 20 \\
\hline 31 & 7,715 & 272 & 30 \\
\hline 32 & 4,598 & 213 & 27 \\
\hline 33 & 8,077 & 300 & 29 \\
\hline 34 & 5,385 & 271 & 20 \\
\hline 35 & 22,605 & 612 & 48 \\
\hline 36 & 8,426 & 219 & 43 \\
\hline 37 & 5,126 & 234 & 26 \\
\hline
\end{tabular}

A.18 
Table A.18. Particle Size Analysis Statistics for Sample \# T3-4

\begin{tabular}{|c|c|c|c|}
\hline Crystal No. & Area, $\mu \mathrm{m}^{2}$ & Max Length, $\mu \mathrm{m}$ & Max Width, $\mu \mathrm{m}$ \\
\hline 38 & 5,981 & 280 & 23 \\
\hline 39 & 39,101 & 1,009 & 56 \\
\hline 40 & 18,161 & 561 & 40 \\
\hline 41 & 3,612 & 156 & 24 \\
\hline 42 & 16,470 & 622 & 39 \\
\hline 43 & 2,954 & 210 & 16 \\
\hline 44 & 2,175 & 108 & 24 \\
\hline 45 & 69,947 & 1,240 & 76 \\
\hline 46 & 5,120 & 211 & 31 \\
\hline 47 & 10,356 & 676 & 18 \\
\hline 48 & 14,546 & 690 & 25 \\
\hline 49 & 40,166 & 1,011 & 55 \\
\hline 50 & 11,748 & 413 & 31 \\
\hline 51 & 8,715 & 300 & 37 \\
\hline 52 & 7,709 & 380 & 22 \\
\hline 53 & 17,839 & 487 & 39 \\
\hline 54 & 15,568 & 695 & 24 \\
\hline 55 & 12,295 & 576 & 23 \\
\hline 56 & 11,245 & 345 & 38 \\
\hline 57 & 4,506 & 186 & 28 \\
\hline 58 & 7,273 & 295 & 26 \\
\hline 59 & 35,916 & 845 & 47 \\
\hline 60 & 6,726 & 184 & 40 \\
\hline 61 & 17,001 & 647 & 27 \\
\hline 62 & 26,482 & 703 & 47 \\
\hline 63 & 50,799 & 1,239 & 58 \\
\hline 64 & 21,121 & 672 & 47 \\
\hline 65 & 6,441 & 238 & 38 \\
\hline 66 & 2,792 & 206 & 16 \\
\hline 67 & 6,022 & 272 & 39 \\
\hline 68 & 23,072 & 1,272 & 28 \\
\hline 69 & 15,243 & 448 & 50 \\
\hline 70 & 13,413 & 351 & 43 \\
\hline 71 & 21,379 & 969 & 27 \\
\hline 72 & 68,440 & 2,486 & 31 \\
\hline 73 & 53,959 & 2,025 & 37 \\
\hline 74 & 36,668 & 824 & 62 \\
\hline 75 & 45,500 & 954 & 51 \\
\hline Mean & 18,410 & 606 & 35 \\
\hline Min & 2,175 & 108 & 16 \\
\hline Max & 69,947 & 2,486 & 76 \\
\hline Sum & $1,380,736$ & 45,432 & 2,632 \\
\hline Std. Dev. & 15,622 & 428 & 12 \\
\hline Variance & $244,054,513$ & 183,254 & 154 \\
\hline Skew & 1 & 2 & 1 \\
\hline Excess & 2 & 5 & 0 \\
\hline Var. Coeff. & 85 & 71 & 35 \\
\hline Obj. Count & 75 & - & - \\
\hline
\end{tabular}

A. 19 
Table A.18. Particle Size Analysis Statistics for Sample \# T3-4

\begin{tabular}{cccc}
\hline Crystal No. & Area, $\mu \mathrm{m}^{2}$ & Max Length, $\mu \mathrm{m}$ & Max Width, $\mu \mathrm{m}$ \\
\hline Img. Area & $19,091,308$ & - & - \\
Total Obj. Count & 75 & - & - \\
Total Img. Area & $19,091,308$ & - & - \\
\hline
\end{tabular}

Table A.19. Particle Size Analysis Statistics for Sample \# T3-5

\begin{tabular}{|c|c|c|c|}
\hline Crystal No. & Area, $\mu \mathrm{m}^{2}$ & Max Length, $\mu \mathrm{m}$ & Max Width, $\mu \mathrm{m}$ \\
\hline 1 & 210,189 & 599 & 518 \\
\hline 2 & 93,997 & 439 & 298 \\
\hline 3 & 6,794 & 125 & 77 \\
\hline 4 & 14,733 & 149 & 149 \\
\hline 5 & 8,256 & 141 & 83 \\
\hline 6 & 169,265 & 624 & 370 \\
\hline 7 & 144,364 & 577 & 348 \\
\hline 8 & 201,878 & 563 & 504 \\
\hline 9 & 174,709 & 627 & 425 \\
\hline 10 & 310,782 & 774 & 553 \\
\hline 11 & 43,544 & 296 & 224 \\
\hline 12 & 819,871 & 1,421 & 1,044 \\
\hline 13 & 202,143 & 589 & 494 \\
\hline 14 & 335,397 & 899 & 523 \\
\hline 15 & 140,226 & 441 & 452 \\
\hline 16 & 352,606 & 821 & 606 \\
\hline 17 & 258,058 & 749 & 525 \\
\hline 18 & 5,156 & 98 & 67 \\
\hline 19 & 4,440 & 123 & 44 \\
\hline 20 & 1,677 & 48 & 44 \\
\hline 21 & 1,628 & 48 & 43 \\
\hline 22 & 2,805 & 78 & 46 \\
\hline 23 & 4,570 & 75 & 75 \\
\hline 24 & 4,043 & 72 & 72 \\
\hline 25 & 2,445 & 56 & 56 \\
\hline 26 & 2,658 & 57 & 57 \\
\hline 27 & 1,243 & 40 & 40 \\
\hline 28 & 4,297 & 73 & 73 \\
\hline 29 & 3,287 & 64 & 64 \\
\hline 30 & 3,556 & 67 & 67 \\
\hline 31 & 654 & 29 & 29 \\
\hline 32 & 1,116 & 37 & 37 \\
\hline 33 & 751 & 30 & 30 \\
\hline
\end{tabular}


Table A.19. Particle Size Analysis Statistics for Sample \# T3-5

\begin{tabular}{cccc}
\hline Crystal No. & Area, $\mu \mathrm{m}^{2}$ & Max Length, $\mu \mathrm{m}$ & Max Width, $\mu \mathrm{m}$ \\
\hline 34 & 751 & 30 & 30 \\
35 & 870 & 33 & 33 \\
36 & 654 & 29 & 29 \\
37 & 6,975 & 93 & 93 \\
38 & 6,775 & 113 & 86 \\
39 & 119,515 & 420 & 372 \\
40 & 2,658 & 57 & 57 \\
41 & 2,658 & 57 & 57 \\
42 & 3,556 & 67 & 67 \\
\hline Mean & 87,513 & 279 & 211 \\
\hline Min & 654 & 29 & 29 \\
Max & 819,871 & 1,421 & 1,044 \\
\hline Sum & $3,675,548$ & 11,728 & 8,862 \\
\hline Std. Dev. & 156,301 & 325 & 234 \\
\hline Variance & $24,429,993,253$ & 105,867 & 54,708 \\
\hline Skew & 3 & 2 & 2 \\
\hline Excess & 11 & 2 & 2 \\
\hline Var. Coeff. & 179 & 117 & 111 \\
\hline Obj. Count & 42 & - & - \\
\hline Img. Area & $19,091,308$ & - & - \\
Total Obj. Count & 2,394 & - & - \\
\hline Total Img. Area & $27,380,421$ & - & \\
\hline & & & - \\
\hline
\end{tabular}



PNNL-18876

WTP-RPT-205, Rev 0

\section{Distribution}

No. of

Copies

OFFSITE
No. of

Copies

ONSITE

1 Pacific Northwest National Laboratory

(Authors will be notified electronically)

J.V. Crum

K6-24

D.E. Kurath

K3-52

R.A. Peterson

P7-22

D.E. Rinehart

K6-24

R.L. Russell

K6-24

Information Release (pdf)

Project File (1)

K3-52

5 Bechtel National Inc.

WTP R\&T Docs (1)

H4-02

F.W. Damerow

H4-02

J.W. Olsen

$\mathrm{H} 4-02$

P.S. Sundar

H4-02

D.L. Herting

H4-02 


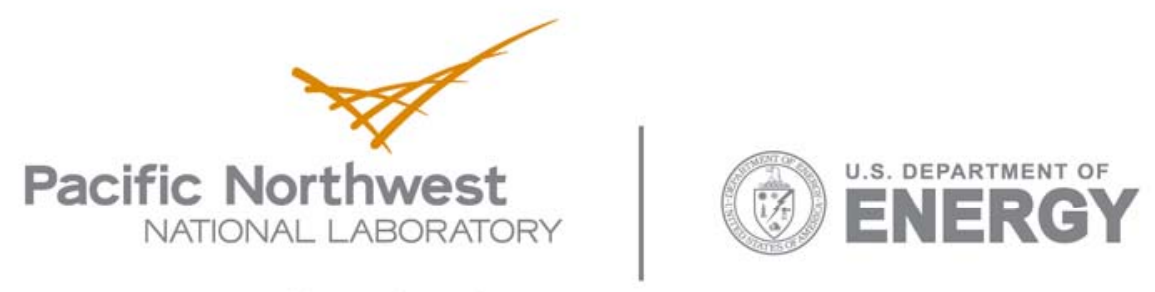

902 Battelle Boulevard

P.O. Box 999

Richland, WA 99352

1-888-375-PNNL (7665)

www.pnl.gov 